Daniel Edler Duarte

\title{
SECURITIZAÇÃO E PRÁTICAS DE (IN)SEGURANÇA NA EUROPA: O CASO DA FRONTEX
}

Dissertação apresentada como requisito parcial para a obtenção do grau de Mestre pelo Programa de Pós-graduação em Relações Internacionais do Instituto de Relações Internacionais da PUC-Rio.

Orientadora: Profa. Monica Herz 


\section{SECURITIZAÇÃO E PRÁTICAS DE (IN)SEGURANÇA NA EUROPA: O CASO DA FRONTEX}

Dissertação apresentada como requisito parcial para a obtenção do grau de Mestre pelo Programa de Pós-graduação em Relações Internacionais do Centro de Ciências Sociais da PUC-Rio. Aprovada pela Comissão Examinadora abaixo assinada.

Profa. Monica Herz Orientadora Instituto de Relações Internacionais - PUC-Rio

Profa. Carolina Moulin Instituto de Relações Internacionais - PUC-Rio

Profa. Elena Lazarou Centro de Relações Internacionais/CPDOC - FGV

Profa. Monica Herz Coordenadora Setorial do Centro de Ciências

Sociais - PUC-Rio

Rio de Janeiro, 26 de novembro de 2012 
Todos os direitos reservados. É proibida a reprodução total ou parcial do trabalho sem a autorização da universidade, do autor e do orientador

\section{Daniel Edler Duarte}

Graduou-se em Relações Internacionais pela Pontifícia Universidade Católica do Rio de Janeiro em 2008. Atualmente é pesquisador associado do Centro de Relações Internacionais da Fundação Getulio Vargas

Ficha Catalográfica

Duarte, Daniel Edler

Securitização e práticas de (in)segurança na Europa: o caso da Frontex / Daniel Edler Duarte ; orientadora: Monica Herz. - 2012. 203 f. : il. (color.) ; $30 \mathrm{~cm}$

Dissertação (mestrado)-Pontifícia Universidade Católica do Rio de Janeiro, Instituto de Relações Internacionais, 2012. Inclui bibliografia

1. Relações internacionais - Teses. 2. Segurança Internacional. 3. Escola de Copenhague. 4. Imigração. 5. União Europeia. 6. Frontex. 7. Sociologia Política Internacional. I. Herz, Monica. II. Pontifícia Universidade Católica do Rio de Janeiro. Instituto de Relações Internacionais. III. Título.

CDD: 327 


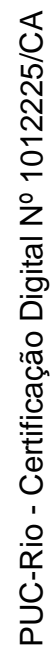

Pro Zé. 


\title{
Agradecimentos
}

No momento de conclusão deste trabalho, há algumas pessoas e instituições às quais devo muito e gostaria de agradecer:

À CAPES pelo auxílio concedido durante o período de Mestrado e à PUC-Rio por compreender a difícil tarefa que é conciliar responsabilidades profissionais e acadêmicas.

\begin{abstract}
À professora Monica Herz, que orientou esta dissertação, compartilhando seu enorme conhecimento acerca do tema e entusiasmo com meu objeto de estudo. Nossos longos encontros foram sempre muito inspiradores e, junto com as sugestões e correções, contribuíram decisivamente para o resultado final de minha pesquisa. Agradeço também pela confiança que demonstrou em meu trabalho mesmo nos momentos em que estive menos presente.
\end{abstract}

À professora Elena Lazarou, que me apresentou um novo campo de estudos e novas formas de olhar para a academia. Sua contribuição para esta dissertação vai muito além da participação na banca de avaliação, tendo nosso convívio diário me proporcionado um crescimento pessoal e profissional.

À professora Carolina Moulin, agradeço pela oportunidade de tê-la em minha banca e pelos debates muito frutíferos sobre teoria das Relações Internacionais. Alguns dos textos utilizados nesta dissertação me foram apresentados em suas aulas e ajudaram a moldar o caminho que esta pesquisa tomou. 
Outros professores do Instituto foram também fundamentais para minha formação e não podem ser esquecidos. Assim, gostaria agradecer aos professors Kai Kenkel e Fabiano Mielniczuk, que me apoiaram e incentivaram mesmo antes da decisão de fazer o mestrado. À professora Letícia Pinheiro, excelente fonte de conhecimento e conselhos nos últimos dois anos. Ao professor Philippe Bonditti, que leu o primeiro rascunho desta dissertação e fez críticas centrais para o desenvolvimento de meus argumentos. Finalmente, ao professor Didier Bigo, que se faz presente em muitas das páginas deste trabalho, por me mostrar as oportunidades presentes na diversidade e a necessidade de pensar a política a partir do diálogo com a diferença.

Faz-se necessário também um agradecimento especial à Fundação Konrad Adenauer, que me proporcionou o contato com muitas das questões abordadas nesta pesquisa. Faço uma menção especial a Peter Fischer-Bollin, Thomas Knirsch e Felix Dane pelo apoio em diversos momentos nos últimos anos, e a Carla Shores, Aline Soares, Gregory Ryan e Reinaldo Themoteo pela amizade que construímos.

Agradeço ainda a todos com quem tenho o prazer de conviver no Centro de Relações Internacionais da Fundação Getulio Vargas: Juliana Marques, Eduardo Achilles, Carlo Patti, Alexandre Moreli, Matias Spektor, Rodrigo Mallea e, mais recentemente, Marcelo Valença.

Sem o convívio com os incríveis colegas de turma (sejam do colégio, da graduação ou do mestrado) meu processo de aprendizagem seria, certamente, muito mais pobre. Por isso, gostaria de agradecer a todos com quem tive o prazer de dividir as salas de aula e as aventuras do amadurecimento.

Agradeço a minha família, especialmente meus pais e meu irmão, por todo o carinho.

Agradeço, por fim, à Carolina, que poderia estar na lista dos colegas de trabalho, dos amigos, da família e dos professores, mas merece um espaço só para ela. 


\section{Resumo}

Duarte, Daniel Edler; Herz, Monica. Securitização e práticas de (in)segurança na Europa: O caso da Frontex. Rio de Janeiro, 2012. 203p. Dissertação de Mestrado - Instituto de Relações Internacionais. Pontifícia Universidade Católica do Rio de Janeiro.

A dissertação analisa de forma crítica parte da literatura de segurança internacional que advoga pela ampliação da agenda do campo, evidenciando as consequências éticas e políticas de se adotar a lógica da securitização em análises sobre questões sociais. Para tanto, são abordadas as contribuições da Escola de Copenhague às análises sobre a política de controle de fronteiras da União Europeia (UE). Este estudo tem como linha condutora as diferentes visões sobre a criação da Frontex, agência que, apesar das acusações de desrespeito aos direitos dos imigrantes, tornou-se a principal produtora de conhecimento acerca dos riscos às fronteiras europeias. Por fim, é abordada a contribuição do campo da Sociologia Política Internacional para os estudos de segurança, especialmente os trabalhos de Didier Bigo e Jef Huysmans. Esta perspectiva realça os principais problemas da ampliação da agenda de segurança e seu impacto no Estado liberal, demonstrando que há uma modificação drástica nas formas de governança, com restrições à liberdade individual em prol de um suposto aumento de proteção. Deste modo, o objeto desta dissertação é tanto a literatura da Escola de Copenhague, compreendendo suas limitações práticas e silêncios políticos, quanto a própria Frontex, cujas operações são evidências empíricas dos argumentos de Bigo e Huysmans.

\section{Palavras-Chave}

Segurança Internacional; Escola de Copenhague; Imigração; União Europeia; Frontex; Sociologia Política Internacional 


\section{Abstract}

Duarte, Daniel Edler; Herz, Monica (Advisor). Securitization and (in)security practices in Europe: The case of Frontex. Rio de Janeiro, 2012. 203p. MSc. Dissertation - Instituto de Relações Internacionais. Pontifícia Universidade Católica do Rio de Janeiro.

This dissertation criticizes part of the literature on international security that advocates for the expansion of the agenda of the field, evidencing the ethical and political consequences of adopting the securitisation perspective while analysing social issues. In this sense, the theoretical contributions of the Copenhagen School to the interpretations of the European Union (EU) policy of boarder control are addressed. This work has as its conductive line the different visions on the creation of the Frontex, an agency that, depite being accused of disrespecting the rights of immigrants, became the main producer of knowledge on the risks to European boarders. Finally, the contribution of the International Political Sociology field to security studies is addressed, mainly through the work of Didier Bigo and Jef Huysmans. This perspective highlights the main problems of widening the security agenda and its impact in the Liberal State, demonstrating that there is a drastic change in the forms of governance, with restrictions to individual freedoms on behalf of an alleged increase in protection. Thereby, the object of this dissertation is both the Copenhagen School literature, understanding its practical limitations and political silences, and Frontex itself, whose operations are empirical evidences of Bigo's and Hyusmans's arguments.

\section{Keywords}

International Security; Copenhagen School; Migration; European Union; Frontex; International Political Sociology. 


\section{Sumário}

1. Introdução

1.1. Liberdade, Segurança e Justiça nas Fronteiras da

União Europeia

1.1.1. Desenvolvimento de políticas comuns para imigração e segurança interna

1.1.2. Proliferação de agências semi-autônomas 23

1.1.3. Frontex 25

1.1.4. Debate sobre a criação da Frontex 31

1.2. Estrutura da Dissertação 32

2. Estudos Críticos de Segurança e a Securitização das Políticas de Imigração na União Europeia 37

2.1. O campo de Segurança Internacional no pós-Guerra Fria 41

2.1.1. Diversidade nos estudos de segurança: tradicionalistas e as escolas críticas

2.2. Contribuições da Escola de Copenhague aos Estudos de Segurança Internacional 54

2.2.1 Instituto de Pesquisas para a Paz de Copenhague 55

2.2.2. O quadro analítico da Escola de Copenhague 58

2.2.3. Relação entre o quadro analítico e os fenômenos sociais 63

2.2.4. Exceção e De-securitização 65

2.2.5 Ampliação da agenda de segurança: o estado da arte dos estudos de securitização $\quad 68$

2.3. Consequências da securitização da imigração na Europa 70

2.3.1 As leituras da Escola de Copenhague para a criação da Frontex 72

3. Discurso e prática: Os vazios da Escola de Copenhague e alternativas teóricas à securitização $\quad 81$

3.1. Os vazios da teoria de securitização 82

3.1.2. Limitações da ferramenta analítica da Escola de Copenhague 83

3.2. Bourdieu e uma leitura alternativa para a segurança internacional 89 
4. Imigração como uma questão de segurança: $O$ longo processo de convergência entre agendas 104

4.1. Desenvolvimento das políticas comuns para imigração 106

4.2. A criação da UE e os novos mecanismos europeus para o controle de imigração

4.3. As respostas europeias ao terrorismo: ausência do processo de securitização

4.4. Contribuições quali-quantitativas para o debate sobre a criação da Frontex

5. Exceção, Práticas e o contínuo de segurança

5.1. Carl Schmitt, Giorgio Agamben e o conceito de político na Escola de Copenhague

5.1.1. O soberano de Schmitt e a construção do inimigo na Escola de Copenhague

5.1.2. Agamben e a manutenção do idioma da exceção 142

5.1.3. Por que evitar a lógica e o jargão da exceção? 145

5.2. (In)segurança e outras formas de governança 150

5.2.1. Práticas e profissionais de (in)segurança 154

5.2.2. Securitização como um contínuo, o "banóptico" e as consequências deste processo 160

6. Conclusão 168 
1.

Introdução

Desde o fim do século XX, com a crescente conscientização sobre o processo de globalização, o debate acerca dos impactos da imigração vem se tornando central para o campo das Relações Internacionais. Ainda incipiente no Brasil, esta área de estudos se desenvolveu largamente na Europa, onde cerca de 29 milhões de pessoas ${ }^{1}$, ou $5.8 \%$ da população, são imigrantes ${ }^{2}$ (Projeto Clandestino $^{3}$, 2008). Levando-se em consideração os números aproximados ${ }^{4}$ do resto do mundo, este tema ganha contornos ainda mais significativos. Atualmente, existem 214 milhões de imigrantes legalizados, mas estima-se ainda que até 30\% das pessoas vivendo fora de seus países de origem estariam na condição de nãodocumentados, dos quais 3 milhões se encontram na União Europeia ${ }^{5}$ (IOM, 2010). Indo além, se forem incluídos deslocamentos internos e transnacionais, o Departamento de Assuntos Econômicos e Sociais das Nações Unidas calcula que $20 \%$ da população mundial viva longe de suas regiões de origem (ONU, 2010).

Os dados, por si só, permitem vislumbrar que as consequências econômicas e sociais deste fenômeno não são pequenas e podem influenciar de maneira decisiva o jogo político europeu ${ }^{6}$. A partir de 2010, com o agravamento da crise financeira na zona do Euro, partidos com retóricas xenófobas ganharam espaço nos parlamentos nacionais, atingindo recordes históricos de votação. O mapa abaixo (mapa 1), produzido para o jornal Le Monde diplomatique em março

\footnotetext{
${ }^{1}$ Destes, 1.6 milhões são refugiados (ACNUR, 2010)

${ }^{2}$ Se forem computados apenas os imigrantes de países extra-comunitários, ou seja, que não façam parte da UE, este número cai para 19 milhões de pessoas, ou, aproximadamente, 3.8\% da população.

Projeto de pesquisa liderado pela Fundação Helênica para Política Externa e Europeia (ELIAMEP) e financiado pela Comissão Europeia.

${ }_{5}^{4} \mathrm{O}$ próprio estudo faz a ressalva de que o número de imigrantes é relativamente impreciso.

${ }^{5}$ Estes números divergem consideravelmente dependendo de quem os apresenta. Segundo Stefano Manservisi, do Diretório-Geral de Assuntos Internos da Comissão Europeia, atualmente há 20 milhões de imigrantes habitando ilegalmente os países da UE. Manservisi, no entanto, apresentou este número em uma conferência de imprensa, não se referindo a nenhum relatório oficial (EurActiv, 2012d), por isso a escolha pelos dados revelados pelos estudos da Organização Internacional para Imigração.

${ }^{6}$ Em 2010, 63\% dos cidadãos de Estados membros da União Europeia afirmaram que a agenda dos candidatos para a imigração afetaria decisivamente sua escolha no momento da eleição (GMFUS, 2011).
} 
de $2012^{7}$, evidencia a representatividade que a extrema-direita alcançou nos últimos meses. Neste, é possível perceber que a radicalização e o receio em relação aos estrangeiros não se resume aos países do sul ou do leste, cujas fronteiras estão nas rotas de entrada para a União Europeia (UE), mas se mostra bastante forte também no norte do continente.

Mapa 1: Desempenho eleitoral dos partidos de extrema-direita na Europa

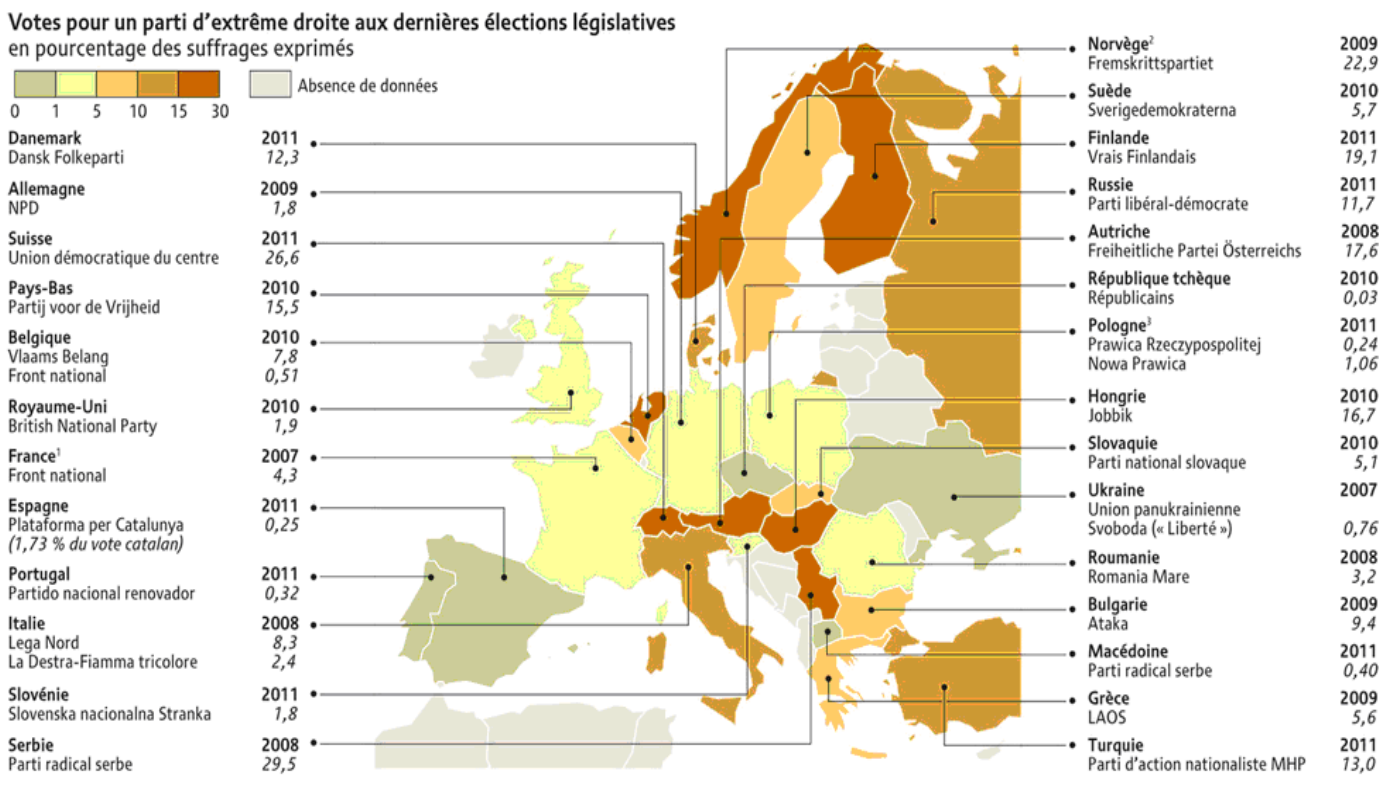

(Marin, 2012)

Recentemente, partidos radicais - aos moldes do Fronte Nacional, de Marine Le Pen (França), e do Partido da Liberdade, de Geert Wilders (Países Baixos) - cresceram pautando suas campanhas em uma argumentação bastante disseminada em meio à opinião pública: que os imigrantes ocupam os postos de trabalho dos europeus e aumentam os índices de criminalidade ${ }^{8}$ (GMFUS, 2011; Mahony, 2012). Apesar do inédito sucesso eleitoral dos partidos preocupados com a imigração, a percepção negativa acerca dos estrangeiros não é nova.

\footnotetext{
${ }^{7}$ Portanto, antes das eleições do dia 06 de maio de 2012 na França e na Grécia que deram resultados bastante significativos para Marine Le Pen, com 17,9\% dos votos, e Nikolaos Michaloliakos - que ultrapassou pela primeira vez a barreira de $5 \%$ para participação no parlamento nacional - com $6,97 \%$ dos votos.

${ }^{8} \mathrm{O}$ German Marshall Fund of the US desenvolveu um estudo comparativo das percepções acerca da imigração nos Estados Unidos e na Europa. Enquanto nos EUA 33\% dos entrevistados afirmaram que os imigrantes aumentam a incidência de crimes nas grandes cidades, na Alemanha e na Itália este número foi ainda maior: $46 \%$ e 56\%, respectivamente (GMFUS, 2011).
} 
Desde os anos 1980, a visão em relação ao papel dos imigrantes na sociedade piorou substancialmente. Em 1988, 40\% dos europeus ${ }^{9}$ já afirmavam que as autoridades nacionais e comunitárias deveriam impor mais barreiras para a imigração. Em $1997^{10}$, esse número subira para $48 \%$ - sendo que $65 \%^{11}$ afirmavam que a quantidade de estrangeiros atingira o limite máximo, 30\% defendiam que imigrantes não deveriam ter acesso a programas sociais e $33 \%$ se declaravam abertamente racistas (Eurobarômetro, 1997). Em 2009, o Eurobarômetro, instituto de pesquisas da Comissão Europeia, publicou um estudo apontando que a imigração ilegal se tornara o terceiro tema mais relevante do projeto europeu de integração, perdendo apenas para os efeitos da crise econômica e a degradação de alguns serviços públicos (Eurobarômetro, 2009).

Percebendo esta tendência, a UE tem envidado repetidos esforços para combater a xenofobia, seja através de medidas de inclusão social ou buscando a unificação dos quadros legais referentes aos imigrantes e refugiados (Geddes, 2000). No entanto, a política que mais avançou nesta área, principalmente nos últimos dez anos, foi a cooperação nos mecanismos de controle para a entrada de estrangeiros. Neste contexto, a criação da agência europeia para o controle de fronteiras, a Frontex, foi fundamental, tendo estabelecido novos padrões para a promoção, coordenação e desenvolvimento de práticas inteligentes/eficientes de gerenciamento das fronteiras (Marenin, 2010).

Em 2006, avaliando a "Global Approach to Migration", conjunto de políticas postas em prática no ano anterior, a Comissão Europeia reconheceu que o número atual de imigrantes não é substancialmente maior que de outros momentos históricos, mas afirmou que este tema se transformou em um grande desafio, pois o alargamento da União gerou maiores pressões em suas fronteiras.

Gráfico 1: Porcentagem de imigrantes entre os países da UE

\footnotetext{
${ }^{9}$ Considerando ainda a Comunidade Europeia com 12 países.

${ }^{10}$ Já tendo se constituído a UE com 15 países.

${ }^{11} \mathrm{Na}$ Grécia este número chegava a $85 \%$. Áustria, França, Reino Unido, Dinamarca e Bélgica apresentavam uma rejeição maior que a média da UE.
} 


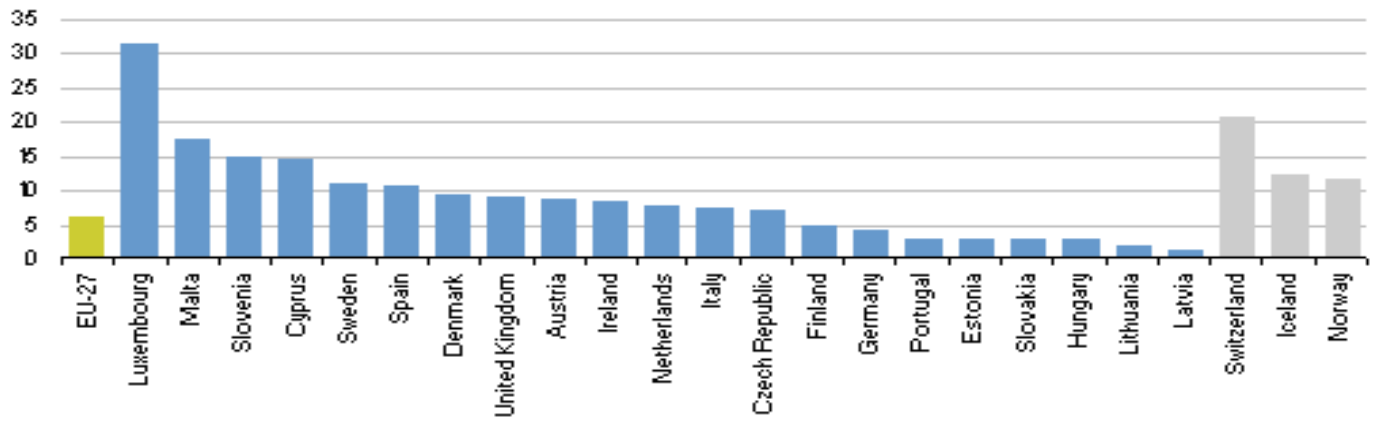

(Eurostat, 2009)

A avaliação aponta para o fato de a Europa precisar de imigrantes para compor o mercado de trabalho - equilibrando a tendência de envelhecimento da população -, mas também alega que estes devem ter qualificações profissionais, pois, de outro modo, aumentariam os índices de desemprego, os custos das políticas sociais e não teriam condições de se integrarem à sociedade (Comissão Europeia, 2006). O relatórioda Comissão conlcui que há um dilema a ser enfrentado pelos países europeus: em um cenário interno de livre circulação de pessoas, como atrair os estrangeiros necessários ao desenvolvimento e bloquear contingentes populacionais indesejáveis?

A integração europeia pode não ter levado ao crescimento significativo do fluxo migratório, mas contribuiu para a percepção de que os Estados não são mais capazes de controlar suas fronteiras sem o auxílio dos demais (Bertozzi, 2008a). Esta percepção foi exacerbada com o fenômeno do terrorismo, que atingiu os Estados Unidos em 2001, mas também a Europa em 2004 (nos trens de Madri) e 2005 (no metrô de Londres). Apesar de não se tratar de um fenômeno inédito em solo europeu ${ }^{12}$, os atentados foram vistos por muitos autores como responsáveis pela guinada nas políticas de imigração da UE, marcadas, cada vez mais, por preocupações de segurança (ver Vries, 2004; Kicinger, 2004; van Krieken, 2005; Bilgic, 2006; Norman, 2006; Lahav et al, 2007; Bertozzi, 2008a, 2008b; Galli, 2008; Bourbeau, 2011).

\footnotetext{
${ }^{12}$ Diversos casos podem ser apontados, entre eles: o assassinato de atletas israelenses nas Olimpíadas de Munique (1972), as ações de grupos de extrema esquerda na Alemanha (BaaderMeinhof) e Itália (Brigada Vermelha) ao longo das décadas de 1970 e 1980, os atentados da extrema direita nestes mesmos países, com bombas na estação ferroviária de Bologna (1980) e na Oktoberfest, em Munique (1980), a explosão do avião da PanAm em Lockerbie (1988) e os ataques de grupos separatistas na Espanha (ETA) e no Reino Unido (IRA) que só desistiram de ações violentas nos últimos anos. Para uma análise sobre o histórico das práticas terroristas pela extrema-direita europeia, ver: Engene, 2011.
} 
Esta literatura se baseia no discurso de alguns atores-chave das políticas europeias de segurança interna. Em palestra para agentes do Centro de Mitigação de Riscos ${ }^{13}$, Gijs de Vries, então coordenador de contra-terrorismo da UE, confirmou que as preocupações no combate ao terrorismo não são recentes, tendo alguns países lutado há décadas contra esta prática. Espanha, Irlanda e Reino Unido, juntos, perderam mais de cinco mil vidas em atentados com diferentes motivações ao longo dos últimos 30 anos. No entanto, de Vries afirmou que o 11 de setembro teria revelado uma transformação importante:

"The nature of terrorism has changed. Whereas it used to be, in the past, a local or regional threat directed against domestic authorities, terrorism has now become a global phenomenon. This type of terrorism requires a global response. We have to be united in our efforts, working with our international partners and the international organisations. Only by working together can we be effective" (de Vries, 2004, p. 1).

Apesar de tratar esta ameaça como um fenômeno global, de Vries deixa claro que há uma preocupação da UE especificamente com o radicalismo islâmico. Ou seja, a nova natureza do terrorismo a qual o representante da UE se refere está intimamente ligada ao papel dos estrangeiros na sociedade europeia e ao receio em relação à potencialidade da imigração como um vetor para o terrorismo (de Vries, 2004).

Tabela 1: Estimativa da população estrangeira residente de forma irregular na União Europeia

\begin{tabular}{|l|l|l|l|l|l|l|}
\hline \multirow{2}{*}{ Ano } & \multicolumn{2}{|l}{$\begin{array}{l}\text { Números absolutos da } \\
\text { população (em milhões) }\end{array}$} & $\begin{array}{l}\text { Porcentagem da } \\
\text { população }\end{array}$ & $\begin{array}{l}\text { Porcentagem da } \\
\text { população estrangeira }\end{array}$ \\
\cline { 2 - 7 } & Mínimo & Máximo & Mínimo & Máximo & Mínimo & Máximo \\
\hline EU-15 & 3.1 & 5.3 & $0.80 \%$ & $1.40 \%$ & $14 \%$ & $25 \%$ \\
\hline $\mathbf{2 0 0 2}$ & 2.2 & 4.8 & $0.58 \%$ & $1.23 \%$ & $8 \%$ & $18 \%$ \\
\hline $\mathbf{2 0 0 5}$ & 1.8 & 3.3 & $0.46 \%$ & $0.83 \%$ & $7 \%$ & $12 \%$ \\
\hline $\mathbf{2 0 0 8}$ & \multicolumn{7}{|l}{} \\
\hline EU-27 &
\end{tabular}

\footnotetext{
${ }^{13}$ Órgão da UE com seções voltadas para questões específicas de segurança. No caso a palestra era para os agentes que lidam com os riscos representados por armas químicas, biológicas e nucleares. Para mais informações, ver: www.cbrn-coe.eu
} 


\begin{tabular}{|l|l|l|l|l|l|l|}
\hline $\mathbf{2 0 0 8}$ & 1.9 & 3.8 & $0.39 \%$ & $0.77 \%$ & $7 \%$ & $13 \%$ \\
\hline
\end{tabular}

(Projeto Clandestino, 2009, p. 4)

Cabe, portanto, entender como se deu o processo de construção das políticas europeias para a imigração e segurança interna, principalmente a partir dos anos 1980, quando a assinatura do Acordo de Schengen começou a colocar em prática a livre circulação de pessoas no espaço europeu.

\subsection{Liberdade, Segurança e Justiça nas fronteiras da União Europeia}

Os debates em torno da criação da "Área de Liberdade, Segurança e Justiça" na UE podem ser comparados, em termos de relevância política e impacto sócio-econômico, às negociações para a criação do mercado único europeu. Se a necessidade de paz foi fundamental para o êxito do projeto de integração nos anos 1950, este só se manteve dinâmico graças a três utopias: o alargamento para o leste, que englobaria os países da esfera soviética; a unificação dos mercados, que transformaria a Europa em uma verdadeira potência comercial; e a livre circulação de pessoas, fundamental para a criação de uma identidade europeia (Dinan, 1994). Nesse sentido, não é surpresa que o pilar de Justiça e Assuntos Internos (JAI), criado para lidar com os variados desafios da cooperação nas fronteiras comuns ${ }^{14}$, seja dos mais ativos ${ }^{15}$.

Este pilar avança em um espaço tradicionalmente enraizado nos sistemas político e judiciário dos países europeus e que está diretamente relacionado à soberania nacional. A demarcação - e controle - das fronteiras e a garantia da segurança interna foram dois dos pontos centrais para a consolidação dos Estados modernos no século XVII (Tilly, 1985). Portanto, ao contrário do que ocorreu com a unificação de mercados - presente desde o Tratado de Roma (1958) entre os objetivos primordiais da integração -, a resistência de líderes nacionais fez com que os temas de justiça e assuntos internos entrassem em pauta somente nos anos 1990. Mesmo hoje, a cooperação nas políticas de imigração e asilo e a criação de

\footnotetext{
14 As competências desde pilar dispostas no Tratado de Maastricht englobavam três temas principais: (1) Políticas de imigração e asilo; (2) Cooperação em questões de segurança interna, atividade policial e controles alfandgários; (3) Cooperação judicial (Tratado de Maastricht, 1992). ${ }^{15}$ Desde 1999, o Conselho aprovou em média dez documentos com inovações neste campo por mês. Para mais sobre a atuação burocrática deste pilar, ver: Monar (2001).
} 
instituições com mandatos específicos para lidar com desafios de segurança interna (Eurojust, Europol, Frontex, entre outras) geram enormes controvérsias.

O crescente engajamento da UE com algumas das funções centrais do Estado exige, fundamentalmente, uma nova visão acerca dos limites da soberania entre os países europeus, mas demanda também uma reflexão a respeito da construção da democracia no nível regional. (Statewatch, 2004; Lavenex, 2010). Apesar de $62 \%$ dos cidadãos considerarem o Acordo de Schengen o resultado mais positivo dos 50 anos de integração (EurActiv, 2012b), a maior liberdade no espaço interno europeu foi acompanhada por medidas autoritárias em suas margens. Sendo mais claro, a contrapartida para os avanços obtidos em Schengen foi o fortalecimento das fronteiras externas e a reificação do etnocentrismo. Observando este fenômeno, alguns autores apontam para o fato de as políticas da União estarem presas à busca de equilíbrio entre segurança e liberdade, como se estes fossem pólos opostos de um mesmo contínuo. Agravando este cenário, argumenta-se que a UE teria optado por privilegiar a segurança ao invés de liberdade (Ette \& Faist, 2006, 2007; Guild, 2009; Kraler \& Rogoz, 2011).

\subsubsection{Desenvolvimento de políticas comuns para imigração e segurança interna}

A institucionalização da cooperação entre forças de segurança interna na Europa remonta ao grupo de TREVI (Terrorisme, Radicalisme, Extremisme, Violence, Information ${ }^{16}$ ), criado em $1975^{17}$. Este reunia ministros de interior e de justiça dos diversos países, promovendo políticas amplas de contra-terrorismo, partilhando experiências entre as forças policiais e facilitando a troca de informações sobre possíveis ameaças ao continente. Contudo, foi apenas após a assinatura do Acordo de Schengen, em 1985, e do Tratado de Maastricht, em 1992, que a UE começou sistematicamente a formular medidas comuns para lidar com este desafio.

Influenciados pelo sucesso da União Nórdica de Passaportes, de 1958, e descontentes com a impossibilidade de atingir um acordo abrangente acerca da

\footnotetext{
${ }^{16} \mathrm{Na}$ sigla em francês: Terrorismo, Radicalismo, Extremismo, Violência e Informação.

${ }^{17}$ Antes do TREVI, já havia sido criado o Clube de Berna, em 1971, e o Grupo Pompidou sobre Drogas (no âmbito do Conselho da Europa), em 1972, mas nenhum dos dois se deu no marco das instituições das Comunidades Europeias.
} 
livre circulação de pessoas durante as negociações sobre o Ato Único Europeu (1986), França, Alemanha e o Benelux ${ }^{18}$ decidiram criar uma área sem controle interno de fronteiras fora do quadro institucional da Comunidade Europeia ${ }^{19}$ (Dinan, 1994). Assim, no dia 14 de junho de 1985, o Acordo de Schengen ${ }^{20}$ foi assinado. Inicialmente, previa-se que a livre circulação de fronteiras teria início em 1990, quando as forças policiais dos respectivos Estados estariam preparadas para cooperar no controle do espaço comum. Contudo, mesmo tendo superado as dificuldades técnicas dentro do prazo estipulado, os governos optaram por adiar a supressão das barreiras para 1993, aguardando a criação formal da União Europeia.

Desde o início, este acordo teve dois aspectos distintos: na medida em que dava maior liberdade aos cidadãos, demandava dos governos a divisão de responsabilidades na implementação das medidas de segurança. Nesse sentido, o fim gradual da vigilância das fronteiras internas foi acompanhado pela adoção de postos comuns de controle nas fronteiras externas, vistos únicos e um sistema de compartilhamento de informações ${ }^{21}$ (Acordo de Schengen, 1985).

Em 1992, o Tratado de Maastricht considerou a ampliação do espaço Schengen como um dos objetivos primordiais da integração ${ }^{22}$ e instou os demais países a adotarem suas cláusulas. Durante a convenção intergovernamental para a formulação deste tratado, ficou decidido que as políticas de asilo ${ }^{23}$ e imigração,

\footnotetext{
${ }^{18} \mathrm{O}$ acordo, inicialmente, não foi assinado pelos três países separadamente - Bélgica, Países Baixos e Luxemburgo. Estes fizeram parte do acordo como "Governos dos Estados da União Econômica de Benelux" (Acordo de Schengen, 1985).

${ }^{19}$ Já havia a livre circulação de pessoas entre os países do Benelux desde 1948, mas, como será visto adiante, o acordo de Schengen ia muito além.

${ }^{20}$ Nome da pequena cidade em Luxemburgo onde os representantes destes países se reuniram.

${ }^{21}$ O Schengen Information System (SIS) é um mecanismo que faz circular informações sobre determinadas categorias de indivíduos, bem como mercadorias perdidas ou roubadas. Posteriormente, este foi incorporado ao acervo da UE e sua função foi definida pelo Conselho: "The information obtained [pelo SIS] is used, in particular, for police and judicial cooperation in criminal matters as well as controls of persons at the external borders or on national territory and for the issuance of visas and residence permits" (Conselho da União Europeia, 2005)

${ }^{22}$ Ver artigo 2 do Tratado da União Europeia (TEU).

${ }^{23}$ Avanço obtido com a Convenção de Dublin sobre asilo. Esta obriga o país pelo qual o indivíduo entrou na União a cuidar dos procedimentos burocráticos e jurídicos do pedido de asilo. Esta decisão tinha como objetivo evitar que uma mesma pessoa abrisse processos de solicitação de asilo em diversos países da UE. Apesar de ter sido assinada em 1990, os dispositivos desta convenção só entraram em vigor em 1997. Em 2002, junto aos demais temas de asilo e imigração, esta Convenção foi incluída no pilar comunitário e no ano seguinte optou-se por substituir este documento por uma nova regulação, a Dublin II. Atualmente, países de fora da União podem adotar estas regras e os casos de asilo estão na jurisprudência da Corte Europeia de Justiça.
} 
controle de fronteiras ${ }^{24}$ e a cooperação judicial e policial ${ }^{25}$ eram assuntos de interesse comum, mas deveriam priorizar a capacidade de atuação individual dos Estados. Sendo assim, estes temas foram reunidos no pilar no qual as decisões ainda eram intergovernamentais, o terceiro (JAI).

O Acordo de Schengen só foi incorporado ao acervo comunitário da União em 1997, com o Tratado de Amsterdã. Neste momento, foi criada a "Área de Liberdade, Segurança e Justiça”, à qual dez países, inclusive não-membros da UE, já haviam aderido ou estavam prestes a aderir: Áustria, Dinamarca, Espanha, Finlândia, Grécia, Islândia, Itália, Noruega, Portugal, e Suécia. Em Amsterdã optou-se por incorporar parte das prerrogativas de Schengen às políticas supranacionais (primeiro pilar), mas a cooperação para o controle de fronteiras e a colaboração entre agentes policiais foram mantidas no âmbito intergovernamental. Irlanda e Reino Unido decidiram aderir apenas ao acervo que permanecia no terceiro pilar, esperando coibir o crime organizado e o trabalho de grupos terroristas em seu território sem abrir mão de parte da soberania.

No Conselho de Tampere, em 1999, a UE lançou as bases para (1) políticas comuns de asilo e imigração, (2) uma área genuína de justiça, (3) luta abrangente contra o crime e (4) uma ação externa forte. As conclusões do conselho apontavam a necessidade de uma UE mais segura e para isso seria imprescindível "[...] to develop common policies on asylum and immigration, while taking into account the need for a consistent control of external borders to stop illegal immigration and to combat those who organise it and commit related international crimes" (Conselho da União Europeia, 1999). Para garantir o cumprimento destas políticas, o Diretório Geral de Justiça e Assuntos Internos $\left(\mathrm{DG} \mathrm{JHA}^{26}\right)$ não era mais suficiente. Romano Prodi, então presidente da Comissão (1999-2004), investiu em um rápido processo de expansão deste setor. Além de

\footnotetext{
${ }^{24} \mathrm{O}$ modelo do SIS foi expandido. Em Maastricht foram lançadas as bases para a criação do Sistema de Informações Alfandegárias (CIS), do Sistema de Informações da Europol (EIS) e o Eurodac, base de dados com digitais dos indivíduos que solicitavam asilo.

${ }^{25}$ Optou-se pela criação da Europol. Iniciando seus trabalhos em 1993 - ainda sob o nome de Europol Drugs Unit (EDU) e sem poder de prisão - com um foco específico no combate ao tráfico internacional de drogas, a Europol rapidamente foi vista como uma instituição central para a segurança do continente e teve sua área de atuação bastante ampliada. Sua autonomia em relação aos Estados foi ratificada em 1998, quando a agência passou a trabalhar em diversos campos do combate ao crime organizado transnacional e ao terrorismo, estabelecendo contatos com forças policiais dos países vizinhos e, assim, sendo um ator bastante influente na parceria EuroMediterrânea (Europol, 2011).

${ }^{26}$ Sigla utilizada para referência ao órgão da Comissão Europeia Directorate General for Justice and Home Affairs.
} 
substituir o DG JHA pelo novo DG de Justiça, Liberdade e Segurança (DG JLS), Prodi aumentou o número de empregados de 46 para $283^{27}$ em quatro anos. Esta expansão também ocorreu no orçamento, passando de $€ 219.4$ milhões, em 2000, para $€ 461.7$ milhões, em 2006, dos quais $53.5 \%$ eram destinados especificamente para os mecanismos de controle de fronteira (Lavenex, 2010).

As decisões de Tampere foram ratificadas no Tratado de Nice, em 2001, sendo, portanto, incluídas no texto de Maastricht. Durante o conselho que debateu a reforma no tratado, os países da UE chegaram a um consenso em torno da necessidade de promover "operational cooperation between the competent authorities of the member states in controlling the Union's external borders, and in particular its sea borders, with a view in particular to curbing illegal immigration" (Conselho Europeu, 2000). No entanto, o desenho institucional desta cooperação só ficaria claro nas conclusões do Conselho de Sevilha, em 2002, após a queda das torres gêmeas em Nova York.

Os atentados de 11 de setembro de 2001 fizeram da segurança interna um dos principais assuntos no Conselho de Laeken, realizado em dezembro do mesmo ano. Neste, os líderes da UE afirmaram que o gerenciamento integrado de fronteiras (IBM) ${ }^{28}$ ajudaria "in the fight against terrorism, illegal immigration networks and the traffic in human beings" (Conselho Europeu, 2001). Assim, o Conselho pedia à Comissão "to work out arrangements for cooperation between services responsible for external border control and to examine the conditions in which a mechanism or common services to control external borders could be created" (Conselho Europeu, 2001).

Ainda neste Conselho, prevendo as dificuldades inerentes ao processo de alargamento da UE e, consequentemente, do Espaço Schengen - que passaria a ter 24 membros e uma área comum de aproximadamente 3.6 milhões de $\mathrm{Km}^{2}$ - o Conselho da UE aprovou ${ }^{29}$ o desenvolvimento de um novo sistema de monitoramento, o SIS II. Coube à Comissão buscar os meios para a criação deste sistema. Apesar de ter sido aprovado poucas semanas após os atentados nos EUA,

\footnotetext{
${ }^{27}$ Entre 1998 e 2002. A tendência de crescimento se manteve após a saída de Prodi e, em 2008, o número de empregados já era de 440, próximo ao de outros DGs importantes como o de comércio e do mercado único (Lavenex, 2010).

${ }^{28}$ Traduzido do original em inglês "Integrated Border Managment" (IBM). Este conceito é central para a estratégia europeia, tendo aparecido com enorme frequência nos documentos de trabalho da Comissão.

${ }^{29}$ Decisão do Conselho da União Europeia em 6 de dezembro de 2001, sobre o desenvolvimento da segunda geração do Sistema de Informação de Schengen (Diário Oficial, 2001, 328/1)
} 
os termos do SIS II já estavam sendo pensados desde as negociações do Tratado de Amsterdã, quando fora identificada uma série de problemas técnicos com a primeira versão (Bertozzi, 2008a). Dentre as inovações, a adoção de um controle biométrico e a maior facilidade para a inclusão e o compartilhamento dos dados entre os oficiais de fronteira eram os principais avanços. Além disso, seguindo as prerrogativas anunciadas em Amsterdã, a Comissão passaria a ter controle sobre este banco de dados, sendo a instituição responsável por definir os procedimentos específicos para o seu uso ${ }^{30}$.

Os Estados se mostraram, mais uma vez, dispostos a abrir mão de parte de sua soberania em troca de programas que garantissem a segurança. Nesse cenário, além do SIS II, surgiu a proposta para criação de novas agências europeias que facilitariam o tráfego de cidadãos europeus e estrangeiros devidamente documentados e bloqueariam indivíduos suspeitos.

Esta ideia foi levada adiante no Conselho de Sevilha (2002), quando a Comissão apresentou o documento "Towards integrated management of external borders of the member states of the European Union". Neste, a falta de coordenação entre políticas de controle foi apontada como um dos graves problemas da segurança europeia. Argumentava-se que a cooperação deveria sair dos discursos e ser efetivamente implantada, seguindo, preferencialmente, cinco elementos: um corpo legislativo comum, mecanismos para coordenação de operações, análises de risco, uma equipe treinada segundo os mesmos padrões e um princípio de compartilhamento de despesas financeiras e responsabilidades (Comissão Europeia, 2002). Feito este diagnóstico, a Comissão sugeria a criação de uma unidade de guardas de fronteira no marco da SCIFA (Strategic Committee on Immigration, Frontiers and Asylum working group $)^{31}$. A proposta era que as equipes a serem criadas dariam apoio ao trabalho de campo dos guardas, mas não

\footnotetext{
${ }^{30}$ Após uma série de dificuldades técnicas em sua implementação, o SIS II teve seu prazo de conclusão, março de 2007, atrasado - a Comissão e os antigos membros chegaram a levantar dúvidas sobre a possibilidade de inclusão dos novos países no espaço de Schengen antes de o SIS II entrar em operação. Para mais informações, ver: http://europa.eu/legislation_summaries/other/133183_en.htm.

31 Segundo nota da presidência do Conselho em 2009: "The Strategic Committee on Immigration, Frontiers and Asylum (SCIFA) was set up as part of a new working structure to prepare the Council's discussions with regard to immigration, frontiers and asylum. SCIFA was initially set up for a five-year transitional period. That mandate was further extended by Coreper on 24 March 2004 for a further period of two years (doc. 7440/04), and again on 29 March 2006 'until such time as the overall working structures in the JHA area are reviewed in the light of relevant developments' (Conselho Europeu, 2009).
} 
os substituiriam. Foi sublinhada, portanto, a importância de programas que aumentassem as relações entre as forças nacionais de fronteira e destas com a SCIFA $^{32}$.

Buscando aprofundar ainda mais a integração, o Conselho de Tessalônica, em junho de 2003, consolidou a intenção dos líderes europeus em formular uma política comum para imigração ilegal. Neste conselho adotou-se muitos dos planos delineados pela Comissão no documento "The development of a common policy on illegal immigration, smuggling and trafficking in human beings, external borders and the return of illegal residents" (Comissão Europeia, 2003). O Conselho consagrou a Sistema de Informação de Vistos (VIS) - paralelo ao SIS - como uma forma inteligente e eficaz de combater a imigração ilegal. Além disso, apresentou dois aspectos essenciais para o sucesso da política comum: estratégias em conjunto com países extra-comunitários para evitar a imigração em sua origem e a celebração de acordos para o retorno dos indivíduos detidos pelas autoridades europeias $^{33}$.

Após Tessalônica, é possível concluir que os líderes europeus estavam preparados para delegar à UE algumas ferramentas de ação que se somariam às políticas nacionais de controle de fronteiras. Em outras palavras, reconheceu-se o valor que a UE poderia agregar neste campo (Bertozzi, 2008a). Apesar disso, o trabalho da equipe de especialistas da SCIFA não obtivera resultados positivos até então, o que levou o Conselho Europeu a enfatizar em suas conclusões que;

"The European Council underlines the importance off full implementation of the Plan for the management of external borders and the setting up of the pending air border centre and the two maritime border centres. All Border Management Centres $^{34}$ should work closely together under the coordination of the Common Unit of External Border Practitioners ${ }^{35}$. The European Council welcomes the

\footnotetext{
${ }^{32} \mathrm{O}$ programa ARGO foi particularmente importante nesta tarefa. Este programa teve início em janeiro de 2002, tendo a duração de cinco anos, nos quais promoveu redes de contatos entre oficiais de fronteira. Ao longo deste período realizou-se uma série de eventos e pesquisas acerca das políticas de visto, gerenciamento de imigrantes e exilados, além de novas tecnologias de vigilância. O programa contou com o orçamento de 26.7 milhões de Euros. Para mais informações, ver: http://europa.eu/legislation_summaries/other/133170_en.htm.

${ }^{33}$ Para avançar em ambas as competências, optou-se neste mesmo Conselho pela criação dos Immigration Liaison Officers (ILO).

${ }^{34}$ Tais centros foram estabelecidos sob recomendação da Comissão a partir das decisões do Conselho de Tessalônica.

${ }^{35}$ Ainda no marco da SCIFA.
} 
Commission's intention to submit a proposal for the creation of a Border Management Agency, in order to enhance operational cooperation for the management of external borders, in time for the Council to reach a political agreement on the main elements by the end of the year. This proposal will draw on the experience of the Common Unit of External Border Practitioners" (Conselho Europeu, 2003).

Trata-se da primeira conclusão do Conselho que incentiva a criação no marco das instituições comunitárias de uma agência especializada na vigilância das fronteiras. Ao fim longo processo descrito, no qual o Acordo de Schengen passou a compor uma área com 400 milhões de pessoas e cujas fronteiras tem mais de 50 mil quilômetros de comprimento ${ }^{36}$ (Comissão Europeia, 2012), fora aberto o espaço institucional para a criação da Frontex.

\subsubsection{Proliferação de agências semi-autônomas}

Se comparado ao contexto da integração à época da assinatura do Acordo de Schengen, é possível afirmar, sem muitas dúvidas, que os temas de justiça e assuntos internos são hoje muito mais complexos. A fim de lidar com os novos espaços da política comum e com os desafios do alargamento, a União optou por criar novas instituições, multiplicando os atores que lidam rotineiramente com o fenômeno da imigração. No entanto, como este campo ainda se divide entre competências comunitárias e intergovernamentais ${ }^{37}$, foi necessário produzir estruturas burocráticas singulares. A alternativa encontrada pelos países europeus foi a proliferação de agências semi-autônomas.

Em 2002, a UE aprovou uma legislação específica para a atuação destas agências $^{38}$. Segundo o texto base da legislação apresentado pelo comunicado da

\footnotetext{
${ }^{36}$ Sendo $42,673 \mathrm{~km}$ por mar e 7,721 km por terra.

${ }^{37}$ Lavenex argumenta que os acordos firmados até o momento guardam reservas importantes para a atuação estatal e não abrangem todos os países da União. Assim sendo, no que tange a JAI, a Europa sustenta um modo "transgovernamental" de tomada de decisão. Este combina métodos comunitários com o intergovernamentalismo. Caracteriza-se pela relativa fraqueza na harmonização dos dispositivos legais, mas com avanços na coordenação de aspectos operacionais entre as autoridades nacionais (Lavenex, 2010). Esse modo de governança "has generated a peculiar pattern of shared competences between sub-national, national and European levels of governance, with the continuity of a significant level of cooperation outside the EU's formal institutions" (Lavenex, 2010, p. 458).

${ }^{38}$ Em 2008 havia 33 agências em operação na UE. Não foram encontrados dados mais recentes.
} 
Comissão, "The operating framework for the European Regulatory Agencies", a organização destas instituições foi pensada para oferecer avaliações técnicas e científicas, auxiliando no trabalho das burocracias nacionais. Para tal, as agências precisavam ser independentes em seu trabalho diário, mas contar com algum mecanismo de accountability. Assim, a Comissão enfatizou a necessidade de um processo de prestação de contas orçamentárias bastante rígido, mas admitiu que o controle sobre o conteúdo do trabalho exercido se desse somente a partir de relatórios de atividades (com periodicidade variável). Apesar da demanda dos deputados europeus, de início, não ficou estabelecida a obrigatoriedade de consultas públicas destes relatórios mediante o Parlamento ${ }^{39}$.

Abaixo (tabela 2) estão listadas algumas das agências mais relevantes da UE, o que permite analisar a transformação de natureza jurídica pela qual estas passaram. No início dos anos 1990, as burocracias semi-autônomas estavam voltadas apenas para assuntos do primeiro pilar da União, auxiliando principalmente com conhecimento técnico - no aprofundamento das políticas comunitárias. Esta realidade mudou sensivelmente nos últimos anos, quando agências voltadas para aspectos da segurança interna europeia começaram a surgir.

Tabela 2: Agências para temas de Justiça e Assuntos Internos

\section{JHA agencies and bodies}

- $\quad$ European Monitoring Centre for Drugs and Drug Addiction (EMCDDA), set up in 1993 in Lisbon to provide factual information on the European drug problems, http://www.emcdda.europa.eu.

- European Police Office (Europol), set up in 1999 in the Hague to share and pool intelligence to prevent and combat serious international organized crime, http://www.europol.europa.eu.

- European Police College (CEPOL), set up in 2000 in Bramshill UK to approximate

\footnotetext{
39 A relação entre a Comissão e o Parlamento no que tange a transparência das políticas direcionadas ao espaço comum é bastante conturbada. Recentemente, esta história ganhou um novo capítulo, quando a presidência dinamarquesa no Conselho avançou uma proposta para que os países tenham o direito de fechar suas fronteiras por até seis meses caso identifiquem ameaças às fronteiras externas do bloco, reforçando um mecanismo presente do Acordo de Schengen. Além disso, os ministros reunidos no Conselho optaram por excluir o Parlamento do mecanismo de codecisão em questões ligadas às fronteiras externas, o que, na prática, torna o tratado um mecanismo intergovernamental. A reação dos parlamentares europeus foi imediata, afirmando que se tratou de uma medida populista que dava muito poder aos Estados membros e à Comissão e retirava a voz da única esfera democrática da União (Nielsen, 2012a).
} 
national police training systems, http://www.cepol.net.

- European Police Chiefs' Task Force (PCTF), set up in 2000 to promote exchange, in cooperation with Europol, of best practices and information on cross-border crime and to contribute to the planning of operative actions, without headquarters and webpage.

- Eurojust, set up in 2002 in the Hague to coordinate cross-border prosecutions, http://www.eurojust.europa.eu

- Frontex, set up in 2005 in Warsaw to coordinate operational cooperation at the external border, http://www.frontex.europa.eu.

- $\quad$ European Fundamental Rights Agency (FRA), set up in 2007 in Vienna as the successor to the European Monitoring Centre on Racism and Xenophobia (EUMC) to provide the Community and its member states when implementing Community law with assistance and expertise relating to fundamental rights, http://www.fra.europa.eu.

- European Asylum Support Office, proposed in $2009^{40}$ to promote the approximation of national asylum recognition practices.

(Levanex, 2010, p. 470)

Esta mudança foi acompanhada por uma transformação na percepção dos governantes europeus em relação à capacidade das burocracias de obterem resultados relevantes. As primeiras agências, apesar da insistência da Comissão por sua criação, ainda eram vistas pelos líderes nacionais como ineficazes, supérfluas e caras. Porém, na medida em que estas se voltavam para o terceiro pilar, seu papel de catalisador da cooperação foi sendo reconhecido. (Bertozzi, 2008b). No caso da Frontex, no entanto, o sucesso não tardou a aparecer. Em 2006, primeiro ano de operações no campo, esta agência colaborou somente em onze ações dos Estados. No ano seguinte, este número se multiplicou, atingindo 24 operações - em terra, no ar e, principalmente, no mar -, que custaram mais de $€ 30$ milhões, e em algumas das quais a Frontex foi a peça fundamental para o planejamento e execução dos planos (Frontex, 2007).

\subsubsection{Frontex ${ }^{41}$}

Conforme visto, os tratados de Amsterdã e Nice impulsionaram a cooperação no gerenciamento das fronteiras comuns. Quando da assinatura destes, a estratégia adotada pela Comissão era de criar centros específicos para lidar com

\footnotetext{
${ }^{40}$ Esta agência recebeu o aval para sua criação em maio de 2010. Para mais informações sobre sua atuação, ver: http://ec.europa.eu/home-affairs/policies/asylum/asylum_easo_en.htm

${ }^{41} \mathrm{O}$ termo Frontex deriva do francês "frontiers extèrieures" (fronteiras externas).
} 
os diferentes aspectos do controle de fronteiras. Em 2002, percebendo que estes centros já haviam proliferado e necessitavam de coordenação, optou-se por fundilos em um mesmo corpo burocrático, a Unidade Comum de Guardas de Fronteira $^{42}$, composta por autoridades nacionais e membros da SCIFA (Frontex, 2012). Contudo, "After two years since the establishment of Ad-hoc centres the European Council decided to go a step further having as an objective improvement of procedures and ways of work of the Common Unit" (Frontex, 2012).

Assim sendo, no dia 26 de outubro de 2004, através da resolução (EC) No. 2007/2004, o Conselho aprovou a criação da European Agency for the Management of Operational Cooperation at the External Boarders of the Member States. Trata-se de uma agência com um arranjo institucional único, estando sob os auspícios do primeiro pilar da UE, mas com prerrogativas de ação do terceiro pilar, observando questões como terrorismo, crime organizado e tráfico de drogas. Desta forma, a Frontex tem autorização para trabalhar como uma força policial usufruindo de ferramentas legais antes restritas a instituições nacionais - para lidar com estrangeiros que buscam alcançar as fronteiras comuns da União.

O documento que regulamenta a atuação desta agência menciona as áreas nas quais ela deve atuar e lista algumas de suas tarefas:

“(a) coordinate operational cooperation between Member States in the field of management of external borders; (b) assist Member States on training of national border guards, including the establishment of common training standards; (c) carry out risk analyses; (d) follow up on the development of research relevant for the control and surveillance of external borders; (e) assist Member States in circumstances requiring increased technical and operational assistance at external borders; $(f)$ provide Member States with the necessary support in organising joint return operations" (Conselho Europeu, 2004, p. 4).

A estrutura da Frontex segue o padrão de outras instituições europeias, sendo comandada por um conselho de administração, do qual participam os

\footnotetext{
${ }^{42}$ Esta unidade era composta por: Centro de Análise de Risco (Helsinque), Centro de Fronteiras Terrestres (Berlim), Centro de Fronteiras Aéreas (Roma), Centro Ocidental de Fronteiras Marítimas (Madri), Centro ad-hoc de Treinamento (Traiskirchen), Centro de Excelência (Dover) e Centro Oriental de Fronteiras Marítimas (Pirineus).
} 
diretores das guardas nacionais dos 25 países da UE que são signatários do Acordo de Schengen e dois representantes da Comissão Europeia. Islândia, Noruega, Liechtenstein, Suíça, Irlanda e o Reino Unido também participam das reuniões, mas com direitos de voto bastante limitados ou nulos ${ }^{43}$. Além de aprovar anualmente os relatórios de atividades e o orçamento, o conselho administrativo é responsável por delinear as diretrizes de trabalho da agência. $\mathrm{O}$ controle externo sobre o financiamento da Frontex é significativo. Ao contrário do que ocorre com outras agências, a proposta de orçamento deve passar pela Comissão e pelo Conselho, além de ser debatida no Parlamento ${ }^{44}$. Estas três instituições da União também são responsáveis por analisar os relatórios anuais de atividade.

Trata-se de uma estrutura pensada para gerar mais eficiência no trabalho diário. $\mathrm{O}$ desenho interno intencionalmente se assemelha ao de grandes empresas e o controle sobre as atividades é feito apenas a posteriori, tendo, portanto, pouca influência no planejamento das operações (Pollak \& Slominski, 2009). O primeiro relatório independente com avaliações acerca da atuação da Frontex foi publicado em 2009 pela empresa de consultoria dinamarquesa COWI. Este analisou dados fornecidos pela agência, e entrevistou funcionários e guardas nacionais que cooperaram com a Frontex em operações de campo. O relatório foi bastante positivo, afirmando que a Frontex "has achieved remarkably much in its short existence. It has established itself as the focal point for community discussions on practical border management and it has developed a path that will enhance cooperation and data sharing" (COWI, 2009, p. 6). As críticas se limitaram a três pontos: a Frontex poderia estar mais aberta ao diálogo com representantes dos imigrantes $^{45}$, percebia-se a necessidade de melhorias na comunicação interna da agência e deveria haver um mandato mais amplo para seu trabalho (COWI, 2009).

Gráfico 2: Estrutura organizacional da Frontex

\footnotetext{
${ }^{43}$ Este último é o caso do Reino Unido e da Irlanda.

${ }^{44}$ Posteriormente, o tribunal de contas europeu averigua os gastos realizados.

45 O documento produzido pela Comissão Europeia em 2011 emendando a regulamentação da Frontex procura responder a esta crítica, obrigando a agência a criar um fórum consultivo sobre direitos fundamentais. Este fórum deve ser criado até o final de 2012 e será composto por diversas organizações da sociedade civil. Para mais, ver Regulamentação N.1168/2011, do Conselho Europeu e do Parlamento Europeu.
} 


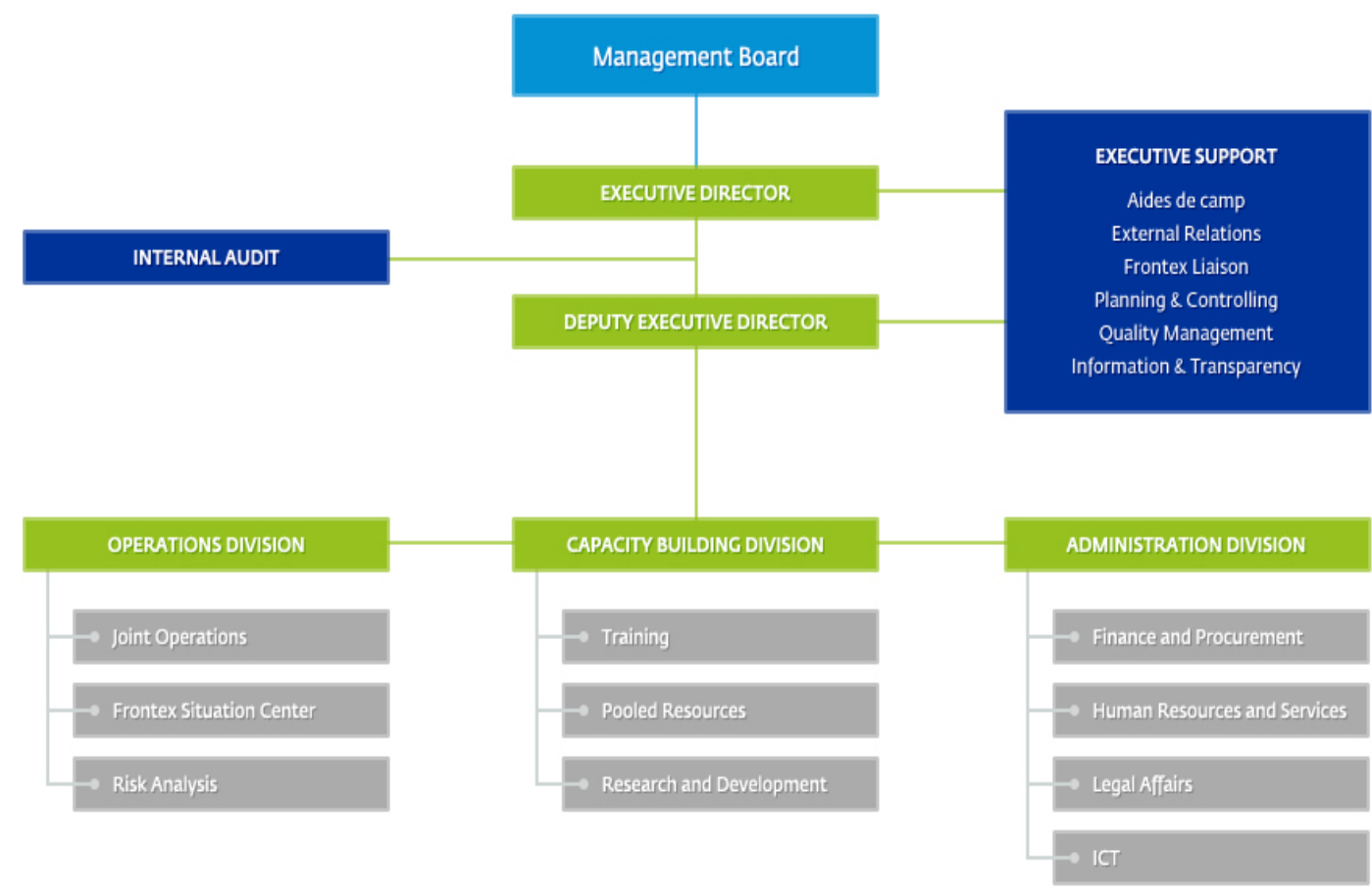

(Frontex, 2012)

No momento da criação da Frontex, o general finlandês Ilka Laitinen foi nomeado seu diretor executivo. O extenso currículo de Laitinen o credenciou para o cargo, tendo o general se envolvido com estratégias de controle de fronteira e políticas de imigração. Antes de ser apontado como diretor executivo, Laitinen compôs a missão da Finlândia ligada aos procedimentos de Schengen e foi codiretor do Council Working Party Frontiers, trabalhando especificamente com o Centro de Análise de Riscos da UE, em Helsinque (Frontex, 2012).

Desde o início de 2005, quando começou a operar a partir da base de Varsóvia $^{46}$, a Frontex vem fortalecendo suas atividades em todos os domínios de competência, o que se reflete no rápido aumento de seu orçamento: entre 2005 e 2011 este se tornou quatorze vezes maior, passando de $€ 6.2$ milhões para $€ 86.4$ milhões ${ }^{47}$ (Frontex, 2011). O crescimento do orçamento, acompanhado pelo maior número de operações e de funcionários ${ }^{48}$, é notável, mas outros aspectos da atuação desta agência também merecem atenção. Desde sua criação, projetos de

\footnotetext{
${ }^{46} \mathrm{O}$ estabelecimento desta agência em Varsóvia não se deu por grande pressão do governo polonês ou por comprometimento com apoio para a estrutura física da agência. De fato, a atitude dos líderes poloneses foi praticamente indiferente, tendo o país recebido a sede da Frontex graças à decisão de alemães e luxemburgueses, que ocuparam o cargo da presidência rotativa da UE à época (Bertozzi, 2008).

${ }^{47}$ A Frontex tem, inclusive, recebido mais recursos que o solicitado pelo conselho administrativo (Marenin, 2010).

${ }^{48}$ De 57, em 2005, para 203, em 2009 (Marenin, 2010).
} 
troca de informação que pareciam inviáveis foram postos em prática ${ }^{49}$. Além disso, a agência trabalhou em prol da formulação e integração de novos sistemas de bases de dados, como o EUROSUR, CIREFI e o ICONet. Visando a facilitar as operações da Frontex, foi criado o sistema $\operatorname{CRATE}^{50}$, que consiste de um inventário do material posto à disposição pelas guardas nacionais. Os equipamentos podem ser utilizados pela agência europeia, mas também por qualquer país da União que esteja enfrentando problemas para o controle de fronteiras - caso da Espanha com as Ilhas Canárias, em 2006 ${ }^{51}$ (Carrera, 2007). Desta forma, o CRATE representa um avanço importante, sendo também bastante representativo da influência que a Frontex passou a exercer em questões de segurança interna.

Admirado com o aparente sucesso da Frontex, que contrastava com os resultados de outras agências, o Parlamento Europeu aprovou em 2007, menos de três anos após o início dos trabalhos, a proposta de expansão de suas funções, abrindo a possibilidade de pôr em campo as "Rapid Border Intervention Teams (RABITs)". Trata-se de um grupo de cerca de 600 guardas responsáveis, quando solicitados, por apoiar as forças nacionais durante um período pré-determinado de tempo e em situações bastante específicas. A esta agência também foi delegada a competência de negociar acordos sobre projetos para o controle de fronteiras e retorno de estrangeiros detidos, pondo em prática algumas das demandas que a Comissão expressara em 1999, durante o Conselho de Tampere ${ }^{52}$.

Até 2004, as avaliações de vulnerabilidade das fronteiras comuns eram produzidas pelos Estados e pelo Centro de Análise de Risco de Helsinque. Porém, a partir da Frontex, esperava-se criar " $a$ hub for an exchange of real-time, operational information between Member States" (Comissão Europeia, 2008, p.

\footnotetext{
${ }^{49}$ Exemplo dos avanços nos debates sobre o SIS II.

${ }^{50}$ O sistema foi criado em 2007. A sigla significa "Centralised Records of Available Technical Equipment managed by Frontex".

${ }^{51}$ Operação HERA I e HERA II. Durante estas operações, que custaram $€ 3.5$ milhões, aproximadamente 22.500 mil imigrantes foram detidos, dos quais 6076 foram extraditados. A Frontex considera estas operações um grande sucesso e atribui uma grande importância ao apoio das autoridades de Senegal e Mauritânia, o que permitiu que em 100\% dos casos fosse possível identificar o país de origem dos imigrantes. Para mais, ver: Carrera (2007) e http://www.frontex.europa.eu/news/longest-frontex-coordinated-operation-hera-the-canaryislands-ZubSEM

${ }^{52}$ Este tópico passou a compor a Política Europeia de Vizinhança, o que permitiu o rápido avanço para a formalização dos acordos com Rússia, Ucrânia, Egito e outros. Mais informações sobre os países com que foram firmados acordos deste gênero e detalhes sobre a cooperação técnica entre os guardas de fronteira estão disponíveis no site da Frontex - www.frontex.europa.eu.
} 
9). Nesse sentido, entre as inúmeras funções da agência, Laitinen afirma que a principal está ligada à Unidade de Análise de Risco. Segundo o diretor executivo, "at the heart of all activities of the agency is carrying out risk analysis. [...] All activities of Frontex are intelligence driven" (Laitinen apud Marenin, 2010, p. 100). Rotineiramente, a agência produz quatro tipos de relatório: balanços gerais de risco, análises específicas a pedido dos Estados, boletins sobre questões urgentes e avaliações para implantação de operações de campo ${ }^{53}$. O primeiro tipo - com informações gerais a respeito das rotas de imigração ilegal, dados acerca da atuação das forças de fronteira e previsões para os fluxos migratórios - é aberto ao público, os demais são secretos.

Apesar da rápida expansão de suas funções, os relatórios de análise de risco desta agência afirmam que, entre 2007 e 2010, o número de estrangeiros detidos ao cruzar ilegalmente as fronteiras europeias caiu cerca de 35\%. A tabela 3 detalha os números exatos desta redução e aponta uma tendência que se deu em todas as rotas identificadas, com exceção de uma: a rota entre Turquia e Grécia. Atualmente, esta fronteira é o foco da agência, tendo o número de detidos crescido $443 \%$ em apenas um ano.

Tabela 3: Número de indivíduos detidos ao atravessar ilegalmente as fronteiras ${ }^{54}$

\footnotetext{
${ }^{53}$ Para informações a respeito da metodologia empregada nos relatórios produzidos pela Frontex, ver: Carrera (2007).

${ }^{54}$ Desde 2007, quando dados sobre imigrantes detidos nas fronteiras começaram a ser sistematizados pela Frontex, o número de indivíduos presos diminuiu, caindo de 163 mil para 104 mil, em 2010 (Frontex, 2011, p. 56). A agência alega que esta redução se deu graças a sua atuação, que gera desincentivos para os imigrantes ilegais. O exemplo dado pela Frontex é a vigilância das costas espanholas e italianas (onde houve uma queda de 47 mil detenções para 14 mil, em apenas três anos). No entanto, a agência alega que se faz necessário um investimento maior nas operações em terra, uma vez que os resultados não foram tão satisfatórios (redução de "apenas" $23 \%$ ). Em seu relatório de análises de risco, a Frontex aponta a fronteira entre Grécia e Turquia como o principal foco de preocupação e demanda maior capacidade de atuação nesta região. Os principais países de origem dos indivíduos detidos são: Afeganistão, Albânia, Iraque, Palestina e Somália. No mesmo relatório de 2011, a Frontex identifica as sete principais rotas de imigração: Tunísia e Líbia para Itália e Malta; Marrocos e Argélia para Espanha; da costa oeste da África para as Ilhas Canárias; dos países da Europa do leste para aqueles que fazem parte da UE; dos Bálcãs para seus vizinhos da UE; da Albânia para a Grécia; e da Turquia para a Grécia (passando também pelo Chipre e pela Bulgária). Em 2010, esta última rota foi onde ocorreram $54 \%$ das detenções. Em resposta às demandas por maior capacidade de atuação, o então ministro de proteção civil da Grécia, Christos Papoutsis, apresentou um pedido para que a Frontex estabelecesse uma operação com suas forças de pronta intervenção (RABIT) em diversas regiões próximas à Turquia (Morehouse \& Bolmfield, 2011).
} 


\begin{tabular}{|c|c|c|c|c|c|c|c|}
\hline $\begin{array}{c}\text { Detections } \\
\text { for illegal } \\
\text { border } \\
\text { crossing }\end{array}$ & $\mathbf{2 0 0 6}$ & $\mathbf{2 0 0 7}$ & $\mathbf{2 0 0 8}$ & $\mathbf{2 0 0 9}$ & $\begin{array}{c}\text { \% change } \\
\mathbf{2 0 0 8 / 2 0 0 9}\end{array}$ & $\mathbf{2 0 1 0}$ & $\begin{array}{c}\text { \% change } \\
\mathbf{2 0 0 9 / 2 0 1 0}\end{array}$ \\
\hline Greece Sea & n.a. & n.a. & 31,729 & 28,841 & $-9 \%$ & 6,175 & $-79 \%$ \\
\hline $\begin{array}{c}\text { Greece Land } \\
\text { with Turkey }\end{array}$ & n.a. & n.a. & 14,480 & 8,782 & $-39 \%$ & 47,706 & $443 \%$ \\
\hline $\begin{array}{c}\text { Greece Land } \\
\text { with Albania }\end{array}$ & n.a. & n.a. & 38,573 & 37,898 & $-2 \%$ & 33,704 & $-11 \%$ \\
\hline Italy Sea & n.a. & 21,580 & 36,947 & 9,570 & $-74 \%$ & 4,400 & $-54 \%$ \\
\hline Spain Sea & 31,678 & 12,478 & 9,181 & 2,244 & $-76 \%$ & 196 & $-91 \%$ \\
\hline Spain land & n.a. & 4,080 & 6,500 & 1,639 & $-75 \%$ & 1,567 & $-4 \%$ \\
\hline Malta Sea & n.a. & 913 & 2,798 & 1,473 & $-47 \%$ & 48 & $-97 \%$ \\
\hline Others & n.a. & n.a. & 18,884 & 14,152 & $-25 \%$ & 10,253 & $-28 \%$ \\
\hline Total & n.a. & $\mathbf{1 6 0 , 1 3 2}$ & $\mathbf{1 5 9 , 0 9 2}$ & $\mathbf{1 0 4 , 5 9 9}$ & $\mathbf{- 3 4 \%}$ & $\mathbf{1 0 4 , 0 4 9}$ & $-\mathbf{1 \%}$ \\
\hline
\end{tabular}

(Frontex, 2011)

\subsubsection{Debate sobre a criação da Frontex}

Devido ao papel central nas políticas europeias e às controvérsias geradas por suas ações nas fronteiras externas comuns (Pop, 2010 e 2011a; Keller et al, 2011; Traynor, 2011), a Frontex se tornou um objeto de análise de especialistas do campo de estudos de segurança. Nos últimos anos, muitos autores se debruçaram sobre esta agência, buscando compreender a natureza de suas ações e, principalmente, o processo político que levou a sua criação.

Há uma vasta literatura que descreve este evento como o resultado de um processo de "securitização" dos fluxos migratórios após os atentados terroristas nos Estados Unidos, em 11 de setembro de 2001 (Zucconi, 2004; van Krieken, 2005; Norman, 2006; Galli, 2008). Baseados no quadro analítico da Escola de Copenhague (Buzan et al, 1998) estas abordagens são pautadas nos discursos de atores da elite política europeia e afirmam que ocorreu uma articulação sem precedentes entre os temas de imigração e terrorismo, resultando na necessidade urgente de respostas por parte dos governos nacionais e das instituições europeias. Assim sendo, a Frontex seria um mecanismo sui generis criado pela UE para responder a desafios emergenciais. 
No entanto, falta a estes argumentos uma perspectiva histórica mais ampla, o que os leva a ignorar o longo processo de produção de discursos sobre a imigração. Estas análises, de um modo geral, trabalham com evidências posteriores aos atentados nos EUA, deixando de compreender uma tendência que se mostra relevante ao menos desde os anos 1980. (Guild, 2009). O terrorismo é, decididamente, um elemento importante, mas deve ser compreendido como parte de um processo que já estava em curso. Assim, os atentados de 2001 não podem ser considerados o ponto de partida para a formulação das novas práticas políticas, mas sim um fator que contribuiu para a articulação entre temas tradicionais de segurança e a imigração.

\title{
1.2. Estrutura da Dissertação
}

Ao longo das duas últimas décadas, houve uma grande expansão na agenda de pesquisa dos estudos de segurança. O fim da Guerra Fria suscitou diferentes questões e, para respondê-las, novas perspectivas ganharam espaço. Assim, esta disciplina, marcada por algumas das posições mais conservadoras no campo das Relações Internacionais, passou por um debate extremamente diversificado, levando Williams (2003) a diagnosticar que:

\begin{abstract}
"Over the past decade, the field of security studies has become one of the most dynamic and contested areas in International Relations. In particular, it has become perhaps the primary forum in which broadly social constructivist approaches have challenged traditional - largely Realist and neorealist - theories on their 'home turf', the area in which some of the most vibrant new approaches to the analysis of international politics are being developed, and the realm in which some of the most engaged theoretical debates are taking place" (Williams,
\end{abstract} 2003, p. 511).

Entre as abordagens que ganharam fôlego neste período, a Escola de Copenhague é, certamente, das mais relevantes. A ferramenta analítica de "securitização" tem sido muito utilizada para explicar o comportamento dos Estados em momentos de crise. No entanto, o uso pouco atento desta abordagem gera consequências graves, que ultrapassam o âmbito da academia. A expansão da 
agenda de segurança, marcada pela definição dos "setores" onde esta lógica pode operar, leva à compreensão de inúmeros fenômenos sociais a partir dos signos da urgência e da exceção. A despeito disso, a Escola de Copenhague tem pouca preocupação com as questões normativas de sua ferramenta teórica. Buzan et al (1998) reconhecem o impacto negativo que a lógica de segurança representa para a democracia e enumeram as vantagens da "de-securitização", mas se distanciam desta questão ao afirmar que o trabalho apresentado serve apenas como uma lente para a realidade, não tendo interferência nesta. Nesse ponto, Wæver (1998) se diferencia dos demais autores desta escola, adotando uma postura marcadamente pós-positivista, na qual admite a influência das ferramentas teóricas na construção da prática política ${ }^{55}$. Apesar da ressalva, há pouco espaço para o debate normativo nesta literatura. Portanto, a partir de uma visão alternativa acerca da criação da Frontex, a dissertação desenvolverá também uma crítica aos postulados teóricos da Escola de Copenhague.

Ao longo da dissertação, a Frontex será observada a partir de um contexto político amplo, incorporando as condições que tornaram possível sua formulação. Caminhando nesta direção, alguns autores críticos, como Andrew Neal (2009) e Christina Boswell (2007), fizeram importantes contribuições a este debate, concebendo a agência como o resultado de uma tentativa fracassada de securitizar a imigração. $\mathrm{O}$ estudo atento dos documentos produzidos por algumas das instituições europeias, principalmente a Comissão, o Conselho e o Parlamento, demonstra que os argumentos mais utilizados para justificar a necessidade da Frontex não giram em torno da "emergência", "urgência" ou "exceção", como levaria a crer a abordagem da Escola de Copenhague. Embora seja possível identificar maior incidência da relação entre os temas de imigração e segurança no pós-11 de setembro, postos em perspectiva, os documentos apontam para continuidade. Assim, pode-se dizer que os políticos europeus estão mais

55 É importante notar que no campo das Relações Internacionais a pesquisa acadêmica é tradicionalmente muito influenciada pela empiria, mas que o caminho inverso também é verdadeiro, uma vez que as agendas de pesquisa são elementos fundamentais na construção do ambiente político no qual os interesses são formulados. Destarte, parte-se do pressuposto de que a atuação dos sujeitos no plano internacional é definida também em função dos constrangimentos lógicos sob os quais esta é formulada. Essa premissa se revela de forma mais clara no campo dos estudos de segurança, sendo, por exemplo, o fim da Guerra Fria um momento de inflexão política que transbordou para a academia. Por outro lado, os projetos de pesquisa críticos que ganharam espaço nas últimas duas décadas foram também fundamentais para a transformação da agenda dos Estados, contribuindo de forma significativa para a produção de políticas de defesa com princípios e práticas bastante distintas. 
preocupados com o fluxo de imigrantes, pedidos de asilo e seus potenciais riscos, mas também que a resposta delineada para estas ameaças não mudou radicalmente.

Conforme buscará revelar a pesquisa documental da dissertação, desde o final da década de 1990 os debates sobre "vigilância", "tecnologia", "biometria", "informação" e "gerenciamento de risco" tem sido mais relevantes que os previamente citados, tendência que permaneceu inalterada após os ataques terroristas. Deste modo, a dissertação pretenderá demonstrar que a aplicação do quadro analítico de "securitização" tem implicações metodológicas bastante graves. Em um primeiro momento, enquanto a Escola de Copenhague está preocupada com momentos de descontinuidade, analisando as relações políticas a partir da lógica da exceção, a perspectiva alternativa explorada na dissertação está mais alerta às práticas diárias das instituições e à tecnicidade presentes nas narrativas dos profissionais de segurança ${ }^{56}$.

Posteriormente, a crítica aborda os problemas de natureza ética e política da ampliação da agenda de segurança e, mais especificamente, da teoria de "securitização". Assim sendo, valendo-se das palavras de Huysmans, a motivação normativa da dissertação é "move from a threat-focused analysis to the interpretation of insecurity as a domain of practice that is produced and reproduced through socially and politically investing security rationality in policy areas" (Huysmans, 2006, p. 6). Nesse sentido, argumenta-se que a Frontex é o resultado de um processo lento e contínuo que concebe o fenômeno da imigração como risco ao relacioná-lo com temas de segurança bastante prementes.

Por fim, esta articulação não é marcada por mudanças radicais em situações específicas, ou por eloquentes discursos, mas procede através de práticas da vida cotidiana. Assim, segundo o ponto de vista da Sociologia Política Internacional, a Frontex não seria o desenlace de políticas de exceção, mas sim de discursos técnicos sobre risco e análises de rotina produzidas por especialistas. Seguindo esta perspectiva, Didier Bigo (1994, 2002, 2005) e Jef Huysmans (2000, 2006a, 2006b) oferecem importantes contribuições para se estudar o surgimento e a consolidação de uma forma de governo baseada nas práticas destes burocratas que, segundo os autores, acabam por fundir o espaço da política com a lógica da

\footnotetext{
${ }^{56}$ Esta perspectiva pode ser identificada a partir de uma abordagem com ênfase na sociologia, presente na "International Political Sociology (IPS)".
} 
segurança. Deste modo, não faria sentido trabalhar com o parâmetro da descontinuidade - momentos de exceção - uma vez que a percepção do risco estaria sempre presente, demandando aparatos de segurança também sempre alertas. Há, portanto, uma governança que se pauta na vigilância, na categorização dos indivíduos e no controle $\mathrm{e}^{57}$ de todas as dimensões das relações sociais. A este fenômeno, Bigo dá o nome de "governmentality of unease" (Bigo, 2002).

A dissertação está dividida em quatro capítulos (além desta introdução e da conclusão), traçando as controvérsias entre as abordagens mencionadas do campo de estudos críticos de segurança e os diferentes argumentos acerca da criação da Frontex. O primeiro capítulo traz uma análise sobre o contexto de ampliação da agenda de segurança, na qual se insere a Escola de Copenhague, discutindo seus principais conceitos e, brevemente, a forma pela qual o quadro analítico apresentado por Wæver e Buzan tem sido utilizado. Além disso, este capítulo abordará especificamente algumas leituras que partem da teoria da "securitização" para explicar o surgimento da Frontex. O segundo capítulo concentra-se nos problemas metodológicos desta literatura, que pressupõe um ineditismo em cenários políticos que, muitas vezes, fazem parte de um longo processo de articulação de significados. Para tanto, será recuperada a contribuição de Pierre Bourdieu para as Relações Internacionais, principalmente a partir das leituras de Anna Leander (2009; 2011) e Bigo (2011), e seu potencial explicativo. No terceiro capítulo, será proposto outro ponto de vista para a criação da Frontex (Neal, 2009; Boswell, 2007; Jorry, 2007; Ekelund, 2008; Jeandesboz, 2008; Léonard, 2011), pautado em uma abordagem metodológica que privilegie uma análise quali-quantitativa (Venturini, 2010; Venturini \& Latour, 2010). O quarto capítulo trata das consequências políticas e éticas mais amplas de se falar em termos de "securitização", focando nos espaços em branco deixados pela Escola de Copenhague. Nesse sentido, este capítulo apresenta algumas das perspectivas teóricas de Michel Foucault, incorporadas ao campo de segurança através de Huysmans e Bigo, compreendendo suas críticas em relação aos demais estudos de segurança e engajando em seu projeto de pesquisa acerca das técnicas/tecnologias de governo pautadas pela lógica da exclusão. A conclusão busca retomar alguns dos debates presentes ao longo da dissertação, demonstrando que o processo de

\footnotetext{
${ }^{57}$ Para alguns, na ilusão de controle (Bigo et al, 2009).
} 
criação da Frontex serve como exemplo da estreiteza das ferramentas analíticas da Escola de Copenhague, mas também de suas consequências normativas, uma vez que esta agência não foi criada como resultado de um processo de "securitização", mas, ao tornar-se operacional, contribuiu para a radicalização do contínuo de segurança, apoiando a produção de novos significados sociais para imigrantes e asilados.

É este processo que será discutido ao longo da dissertação, especialmente no que compete à estruturação de um grupo específico de argumentos sobre segurança internacional e sua influência na construção da política de controle de fronteiras da União Europeia. 
2.

\section{Estudos Críticos de Segurança e a Securitização das Políticas de Imigração na União Europeia}

O campo da segurança está no cerne das Relações Internacionais (RIs) desde as primeiras tentativas de conceber esta como uma disciplina independente entre as ciências sociais. Mesmo antes de sua consolidação como uma área de pesquisa, o que se deu logo após a Primeira Guerra Mundial, elementos dos estudos de segurança já se mostravam centrais nos trabalhos de Alfred Mahan, Antoine-Henri Jomini, Carl von Clausewitz e Giulio Douhet. No entanto, esta literatura sobre guerra e paz trazia ainda uma preocupação muito voltada para estratégias militares ${ }^{58}$, ignorando os impactos políticos advindos da reorganização da ordem global e os aspectos mais gerais da segurança internacional. Assim, apenas com o fim da Segunda Guerra Mundial, o surgimento do sistema bipolar e o início da Guerra Fria, esta sub-área de estudos pôde se firmar.

Decerto que fatos históricos influenciaram substancialmente o desenvolvimento da disciplina, sendo um fator importante nos debates acadêmicos e na construção de sua agenda de pesquisa. Contudo, o caminho inverso também é verdadeiro, tendo as proposições teóricas contribuído para a formação da visão de mundo dos formuladores de política. Durante os anos 1950 e 1960, por exemplo, o enorme impacto das armas nucleares acarretou na predominância de assuntos militares e aproximou os pesquisadores à esfera de decisão dos Estados. A produção de análises a respeito do uso destas armas, contenção e dissuasão era tão extensa que se convencionou caracterizar estas décadas como a "era de ouro" dos estudos estratégicos (Collins, 2007; Buzan \& Hansen, 2009). Porém, é um equívoco afirmar que o campo pautava-se somente pelo enfoque das forças armadas. Parte do esforço acadêmico para o fomento destes estudos se deu justamente no sentido de organizar um grupo de civis capazes de debater sobre segurança $^{59}$. Desta forma, especialistas de diferentes áreas desempenharam papéis relevantes, incorporando às discussões elementos das ciências naturais

\footnotetext{
${ }^{58}$ Tratava-se ainda de Estudos de Guerra e História Militar. Para mais, ver: Moran, 2002.

${ }^{59}$ A RAND Corporation, criada em 1948, é uma das instituições que surgiram nesse período com o objetivo de fomentar o debate sobre política pública e temas de segurança nos Estados Unidos. Ainda em seu primeiro ano de trabalho, a RAND já contava com uma equipe de 200 especialistas, divididos entre engenheiros, matemáticos, físicos, químicos, economistas e psicólogos.
} 
(principalmente a partir da física e da matemática), da sociologia, da economia e da psicologia ${ }^{60}$.

Neste mesmo período, alguns dos questionamentos mais substanciais das RIs e, especificamente, sobre a natureza do campo de segurança, já estavam presentes. (1) Havia uma relevante preocupação sobre o escopo das análises. Por que apontar o Estado como objeto referencial ideal? O "algo a ser protegido" não seria o indivíduo, a sociedade, a humanidade ou mesmo o planeta? (2) A visão hegemônica abordava os desafios para o Estado em meio ao sistema anárquico e, portanto, relacionava os debates sobre segurança a questões de soberania e integridade territorial. Contudo, já se perguntava também sobre a incorporação ou não de ameaças internas. (3) Outra demanda presente desde então girava em torno da expansão do conceito de segurança para além dos assuntos militares. Temas como economia, energia e acesso a recursos naturais estavam presentes somente na medida em que afetavam o uso da força pelo Estado. Johan Galtung ${ }^{61}$ (1969), porém, apontava para a necessidade de abordar com o mesmo rigor temas relacionados às necessidades humanas e à violência estrutural. (4) Por fim, já se levantava o questionamento sobre se o conceito de segurança estaria por definição ligado à urgência e à dinâmica das ameaças. Embora ainda marginais, preocupações éticas sobre o impacto desta abordagem já existiam (Buzan \& Hansen, 2009).

Analisando estes questionamentos, é possível afirmar que há importante interseção entre os grandes debates das Relações Internacionais ${ }^{62}$ e o desenvolvimento dos estudos de segurança, cujas raízes podem ser identificadas no período do entre-guerras (1918-1939) e cujos desdobramentos são claros ainda hoje.

\footnotetext{
${ }^{60}$ Para uma ampla lista de autores destas diferentes áreas que contribuíram para o campo, ver: Tanno, 2002, p. 15/16.

${ }^{61}$ É importante ressaltar que Galtung não fazia parte dos debates sobre segurança que ocorriam na academia norte-americana. Sua produção se dava no campo de estudos para a paz que, neste momento, desenvolvia-se de forma bastante independente e tinha como interlocutores, basicamente, outros pesquisadores escandinavos.

${ }^{62}$ É válida a ressalva que Wæver (1998) apresenta acerca das distorções geradas ao se trabalhar com a imagem do campo a partir de grandes debates. Segundo o autor, ao se referir somente a estes e, principalmente, ao caracterizar a disciplina a partir de uma periodização que foca em momentos específicos no qual houve embate entre metodologias, epistemologias ou ontologias distintas, se está ignorando a pluralidade de autores que sempre houve nas Relações Internacionais. Estes debates seriam, portanto, uma mitologia da disciplina, que serviria para dar ordem a um campo que nem sempre foi guiado segundo conceitos dicotômicos.
} 
As controvérsias entre liberais (ou idealistas) e realistas clássicos influenciaram, por exemplo, a diplomacia de Woodrow Wilson e os descaminhos da Liga das Nações. Criada para garantir a paz no pós-Primeira Guerra, esta instituição tinha como base a compreensão de um sistema internacional organizado a partir dos princípios da democracia, do livre-comércio e da liberdade individual. O legado teórico de Immanuel Kant, principalmente a utopia da Paz Perpétua, foi fundamental para os liberais e suas predileções normativas. Contudo, a crise no concerto político vigente serviu para alimentar as críticas dos realistas a esta postura teórica. Apoderando-se da visão hobbesiana sobre o estado de natureza, os realistas percebiam um sistema internacional bastante distinto, marcado pela falta de cooperação e pelo auto-interesse. Na base desta crítica estava a percepção de que os Estados não deveriam formular suas políticas a partir de utopias sobre a harmonia dos povos, mas sim observar análises sobre a conjuntura real de distribuição de poder. Nesse sentido, ao referir-se à Wilson e seus 14 pontos $^{63}$ como "idealistas", rompia-se com qualquer espaço para o diálogo e rotulava-se a tradição liberal como "não-ciência"64.

O início da Segunda Guerra Mundial representou um golpe definitivo à corrente liberal. O legado kantiano perdeu espaço, dando lugar a argumentos pautados nas obras de Maquiavel e Hobbes. Assim, o mundo que emergiu no pós1945 passou a ter como intérpretes mais influentes os autores realistas, principalmente Hans Morgenthau e Reihold Niebuhr.

De uma forma geral, o realismo enfatiza os constrangimentos impostos pela natureza humana egoísta e pela ausência de um governo mundial. Nesse sentido, analisa as relações internacionais como um domínio do poder e dos interesses. Esta corrente apresenta três princípios básicos: (1) o sistema

\footnotetext{
${ }^{63}$ Proposta formulada pelo presidente Woodrow Wilson após a Primeira Guerra Mundial. Além de tratar de temas específicos sobre divisão de territórios na Europa, este documento apresentava um novo padrão para a relação entre os países, defendendo, entre outras questões: uma diplomacia aberta, a liberdade nos mares, abolição de barreiras econômicas e a criação de uma instituição supranacional capaz de aumentar a confiança entre os Estados e evitar guerras (Wilson, 1918).

${ }^{64}$ É marcante neste debate a obra de Edward Carr (2001 [1939]), na qual o autor busca certa autonomia em relação ao debate teórico contemporâneo, avançando críticas significativas aos institucionalistas liberais, mas formulando argumentos que também se distanciam do realismo clássico. Em "Vinte Anos de Crise 1919-1939", Carr trata das motivações para o surgimento de uma teoria de relações internacionais e suas premissas. O autor produz seu trabalho em um momento de crise da tradição utópica, apresentando críticas contundentes ao "fazer teórico" desta corrente. No entanto, ao contrário dos realistas clássicos, não assume totalmente os pressupostos positivistas, argumentando que o fato social não seria perfeitamente distinguível do pesquisador que o observa, ou seja, o objeto e a análise seriam partes de um mesmo processo, em que a análise poderia alterar o próprio objeto estudado.
} 
internacional seria anárquico, o que geraria uma situação de conflito permanente; (2) os Estados teriam como objetivo primordial a sobrevivência, que só poderia ser garantida através da maximização de seu poder e ganhos relativos; e (3) os governantes tomariam decisões de política externa baseados em suas crenças, na dinâmica política doméstica e na avaliação dos constrangimentos do sistema internacional $^{65}$ (Donnelly, 2000). Apesar da complexidade destas três dimensões políticas, o comportamento dos Estados poderia ser previsto, pois estes seriam atores racionais. $\mathrm{O}$ método realista baseava-se, portanto, na percepção de que os Estados agem segundo um cálculo de custos e benefícios, pesando seus interesses e os constrangimentos externos para alcançá-los antes de tomar decisões estratégicas.

Conforme visto, foram nesses anos que as contribuições de outras áreas do conhecimento se fizeram mais presentes. Pertencentes a um campo ainda em formação, vivendo uma época sem precedentes históricos de guerras nucleares e enfrentando dificuldade de acesso a documentos, os pesquisadores recorreram à capacidade explicativa de modelos matemáticos abstratos - entre eles, a teoria dos jogos - de modo que o racionalismo se tornou uma característica marcante dos estudos de segurança. Os trabalhos focavam, em sua maioria, nos desafios militares para a defesa nacional, relegando outras possíveis fontes de conflito ao segundo plano. Durante os primeiros vinte anos da Guerra Fria esta perspectiva teórica foi a que mais influenciou as decisões políticas e a que definiu grande parte das pesquisas.

Somente a partir da metade dos anos 1960, com a redução das tensões entre os Estados Unidos e a União Soviética, o foco militar do campo começou a ser confrontado. Na década seguinte, as dificuldades econômicas advindas da crise do petróleo fortaleceram as críticas a alguns dos pressupostos realistas e trouxeram novas perspectivas para os estudos de segurança. Autores como Robert Keohane e Joseph Nye $(1972 ; 1977)$ ganharam notoriedade desenvolvendo estudos sobre interdependência e relações transnacionais. É deste período também

\footnotetext{
${ }^{65} \mathrm{O}$ último ponto descrito refere-se à divisão conceitual apresentada por Kenneth Waltz em "Man, the State and War" (1959). Trata-se de uma obra fundamental para o pensamento realista da época que, posteriormente (como será visto a seguir nesta seção), o próprio autor reviu. No final dos anos 1950, Waltz acreditava ser necessário observar estas três dimensões para entender o comportamento dos Estados no sistema internacional, mas, 20 anos depois, o autor reduziu o escopo da análise apenas para o terceiro nível, afirmando que o padrão anárquico do sistema era a chave para explicar a atuação das unidades.
} 
a expansão do uso das teorias organizacionais nos assuntos de segurança, incorporando novas ferramentas na compreensão dos determinantes para decisões desta natureza $^{66}$ (Nye \& Lyn-Jones, 1988).

Contudo, em 1979, quando os argumentos realistas perdiam o predomínio da disciplina, Kenneth Waltz publicou o livrou "Theory of International Politics", respondendo às críticas e construindo as bases do neorealismo. Nesta obra, o autor reafirma a importância do "fazer teórico" positivista, alegando que a produção científica não deveria ter motivações políticas, mas sim pautar-se na total separação entre o sujeito e o objeto de análise. Além disso, o autor incorpora elementos históricos e estudos empíricos que o ajudam a definir a estrutura do espaço internacional como condicionante decisivo para o comportamento dos Estados. Além da contribuição de Waltz, eventos políticos, mais uma vez, influenciaram a agenda de pesquisa e propiciaram o renascimento dos estudos de segurança. O fim do período de distensão, marcado pela invasão da URSS no Afeganistão e a ascensão de Ronald Reagan à presidência dos Estados Unidos, foi fundamental para este processo, diminuindo a cooperação internacional e as esperanças de construção de uma ordem global mais pacífica (Halliday, 1987; Walt, 1991).

No início dos anos 1980, a influência de Waltz era inquestionável e, embora houvesse uma série de autores críticos formulando perspectivas diferentes sobre as relações internacionais, não parecia haver ameaças à centralidade do neorealismo.

\subsection{O campo de Segurança Internacional no pós-Guerra Fria}

"In contrast to the massive visible threat in the cold war, none of the new threats is purely military; nor can any be tackled by purely military means. Each requires a mixture of instruments [...] Dealing with terrorism may require mixture of intelligence, police, judicial, military and other means ${ }^{67,}$ (Conselho Europeu, 2003, p. 12)

\footnotetext{
${ }^{66}$ O livro "Essence of Decision: Explaining the Cuban Missile Crisis" (1971), de Graham Allison é um marco para a incorporação de estudos organizacionais nos campos da análise de política externa e de segurança.

67 Extraído do relatório apresentado por Javier Solana, então Alto Representante da União Europeia para a Política Externa e de Segurança Comum, ao Conselho Europeu de Tessalônica,
} 
A década de 1980 trouxe, no entanto, importantes mudanças para a disciplina de Relações Internacionais. Paradigmas enraizados foram contestados e algumas das teorias em voga, antes protegidas por sua autoproclamada habilidade de "explicar o mundo", se viram incapazes de compreender os fenômenos políticos mais decisivos do período. A fragmentação da União Soviética e, consequentemente, a superação do sistema de poder bipolar influenciaram de maneira decisiva a forma pela qual os analistas interpretam os desafios para a segurança internacional.

Até então, pautando suas observações nos desequilíbrios da balança de poder, os autores neorealistas (e realistas neoclássicos) eram os mais celebrados da academia (Waltz, 1979; Lebow, 1988; Walt, 1991; e Chipman, 1992). A lógica da Guerra Fria, marcadamente geopolítica, comandava a agenda dos governos, subordinando todas as demais preocupações a questões de natureza militar. Conforme resumido por Buzan, "States were seen as locked into a power struggle, and security was easily seen as a derivative of power, especially military power" (Buzan, 1991, p. 8).

Nesse contexto, cabia aos governantes gerenciar de forma racional suas capacidades, garantindo a proteção dos interesses nacionais. A imagem de um sistema internacional caracterizado pela anarquia hobbesiana ${ }^{68}$, com cenários políticos potencialmente conflituosos, era essencial para esta corrente, sendo a base sobre a qual se constituíam as relações entre os Estados. A influência desta caracterização do sistema era tão significativa que Ken Booth (1991), avesso a essa visão, chegou a afirmar que as questões enfrentadas pelos acadêmicos eram as mesmas colocadas pelos formuladores de política. Segundo o autor:

"The dominating security questions were: is the Soviet threat growing? What is the strategic balance? And would the deployment of a specific weapon help stability? In that period of looking at world politics through a missile-tube and

em 2003. Neste relatório - "A Secure Europe in a Better World" -, Solana delineia as principais ameaças a serem enfrentadas pela UE no novo século, bem como as medidas que deveriam ser adotadas para a contenção destas. Após sua aprovação pelo Conselho, este documento se tornou a Estratégia de Segurança Europeia.

${ }^{68}$ Conforme a caracterização apresentada por Wendt (1999), na qual os padrões de comportamento em um ambiente anárquico podem variar entre "hobbesiano", "grotiano" e "kantiano", dependendo de seu caráter mais conflituoso ou cooperativo. 
gun-sight, weapons provided most of the questions, and they provided the most of the answers - whatever the weapon, whatever the context, whatever the cost". (Booth, 1991, p. 315-316).

Dada a centralidade dos conceitos neorealistas, relativamente bem sucedidos em interpretar a estrutura pouco dinâmica do período, os debates acadêmicos viam-se limitados por uma relativa pobreza de diversidade teórica. Eram raros os casos em que os autores engajavam em argumentações substanciais acerca da natureza de conflitos, espaços para cooperação e possibilidades de ampliação da agenda de segurança (Ullman, 1983). As críticas mais recorrentes ao neorealismo eram proferidas por neoinstitucionalistas, entre eles, Keohane. Em "After Hegemony" (1984), este autor abordou o tema da hegemonia indo além das capacidades materiais dos Estados. Apesar disso, o debate sobre a formação dos interesses continuou bastante reduzido, pois Keohane acredita, à semelhança dos neorealistas, que estes são naturais, não sofrendo alterações a partir da interação entre os países.

No entanto, o fim da Guerra Fria foi acompanhado pelo alvorecer de novas perspectivas teóricas e pela contestação de muitas das bases da disciplina ${ }^{69}$. A percepção de que um conflito nuclear envolvendo os Estados Unidos e a União Soviética não era mais uma ameaça premente contribuiu para o declínio dos temas puramente militares, colocando as premissas neorealistas em xeque e levando os autores a se envolverem mais longamente com as questões levantadas pelos estudos críticos. Esta transformação no sistema internacional também evidenciou três problemas centrais nas abordagens tradicionais de segurança: (1) esta era etnocêntrica, voltada apenas para as preocupações norte-americanas no campo; (2) focava somente o Estado, o que não permitia uma flexibilidade no reconhecimento de outros objetos referenciais; e (3) como tratava apenas de assuntos militares, não satisfazia o anseio pelo reconhecimento de novos desafios à segurança internacional que emergiram com a acentuação do processo de globalização (Fierke, 2007).

\footnotetext{
${ }^{69}$ Tanno argumenta que o campo se desenvolvia sem que algumas de suas questões mais básicas fossem desenvolvidas. Para a autora, temas como o escopo dos estudos de segurança, as metodologias empregadas nos programas de pesquisa e as prioridades normativas dos trabalhos produzidos foram subestimados durante anos, ganhando espaço apenas com as correntes críticas na segunda metade dos anos 1980 (Tanno, 2002).
} 
Às críticas sintetizadas por Karin Fierke somou-se o questionamento acerca do monopólio positivista. Diversos autores iniciaram um movimento de pensar o espaço internacional a partir das contribuições da ciência política, trazendo argumentos distintos e identificando uma resistência por parte das principais correntes da área em entrar no diálogo ontológico - acerca dos conceitos centrais da disciplina - e epistemológico - sobre a capacidade de produção de conhecimento partindo de diferentes perspectivas (Der Derian e Shapiro, 1989; Walker, 1993; Sylvester, 1994; Ashley, 1996).

Nesse campo, neorealistas e neoinstitucionalistas eram unânimes em apontar a possibilidade de separação entre o espaço do analista e a realidade que este busca explicar, e em afirmar a necessidade de incorporar os parâmetros das ciências naturais para que as hipóteses formuladas fossem empiricamente testáveis. Deste modo, havia uma resistência em dialogar com as críticas pós$\operatorname{positivistas}^{70}$. Durante a abertura da $29^{\mathrm{a}}$ Convenção Anual da International Studies Association ${ }^{71}$ (ISA), Keohane, então presidente da ISA, fez um célebre discurso sobre o debate entre racionalistas e reflexivistas, reconhecendo algumas limitações das teorias dominantes, mas exortando os críticos a estabelecerem um padrão científico para seus argumentos. Segundo o autor:

\begin{abstract}
"Reflective approaches are less well specified as theories; their advocates have been more adept at pointing out what is omitted in rationalistic theory than in developing theories of their own with a priori content. Supporters of this research program need to develop testable theories, and to be explicit about their scope. [...] Without such detailed studies, it will be impossible to evaluate their research program" (Keohane, 1988, p. 393).
\end{abstract}

Neste mesmo discurso, Keohane afirma que, após os reflexivistas adotarem o "fazer teórico" positivista e, portanto, desenvolverem programas científicos de pesquisa, seria fundamental a síntese entre as duas abordagens. Esta permitiria uma compreensão mais ampla da realidade e uma maior interferência

\footnotetext{
${ }^{70}$ Cabe aqui a ressalva de quem está sendo classificado como pós-positivista. Como o próprio rótulo apresenta, este grupo é definido a partir da oposição à outro. Desta forma, não há, neste momento, um interesse em distinguir os diferentes argumentos que o compõe, apenas ressaltar as características principais que os separam dos positivistas. Ou seja, podem ser inseridos os autores que construam conhecimento sem buscar a separação entre sujeito e objeto e que produzam pesquisa incorporando em suas agendas o valor de normas e ideias (Lapid, 1989).

${ }^{71}$ Realizada no dia 31 de março de 1988, em St. Louis, nos Estados Unidos.
} 
no processo político. Alexander Wendt $(1992 ; 1999)$ acatou esta sugestão e buscou se colocar como uma via média. O autor se aproxima das correntes teóricas centrais ao apresentar uma metodologia positivista, mas traz uma mudança de perspectiva, saindo da análise pura de capacidades e distribuição de poderes para uma discussão sobre identidades. Enquanto Waltz perguntava "o que o Estado pode fazer dada a sua posição na estrutura?", Wendt avançava na investigação sobre "o que o Estado quer fazer dada a forma como ele se vê em relação aos demais".

O construtivismo de Wendt foi bem recebido pelas correntes tradicionais, que viram pela primeira vez a possibilidade de um debate com a teoria social que se desenvolvesse sobre bases científicas (Katzenstein et al, 1998). A partir deste debate, o construtivismo (e a preocupação com normas e subjetividade) ganhou espaço no campo de estudos de segurança, sendo a publicação do livro "The Culture of National Security: Norms and Identity in World Politics", de 1996, um marco desse processo (Katzenstein, 1996).

No entanto, Wendt é bastante criticado pelos pós-positivistas, inclusive pelos demais construtivistas (Onuf, 2009). É perceptível no trabalho deste autor uma permanente tensão entre a busca por uma teoria holista e idealista (no sentido de levar em consideração o papel das ideias), e a afirmação de que "the world is independent of the mind and language of individual observers; [...] mature scientific theories tipically refer to this world, even when it is not directly observable" (Wendt, 1999, p. 51).

De um modo geral, os pós-positivistas condenam o movimento de síntese buscado por Wendt, apontando uma incongruência que não pode ser resolvida em seu trabalho. Nesse sentido, levantam-se dois questionamentos: como unir uma metodologia que prima pela separação entre sujeito e objeto, entre a realidade objetiva e a imagem que se faz dela, a uma abordagem que visa a entender o papel das ideias na política externa dos Estados? Indo além, como pode existir uma premissa de realidade construída a partir das interações sociais intersubjetivas se a mente e a linguagem do indivíduo não interessam metodologicamente? (Smith, 2001).

Esta competição entre as abordagens racionalistas, marcadamente economicistas, e interpretações reflexivistas, com análises pautadas na hermenêutica, não se restringe às Relações Internacionais, sendo uma marca das 
ciências sociais como um todo, mas se torna evidente no debate normativo presente nos estudos de segurança. Foi neste cenário de contestação teórica que o campo se tornou mais plural. Na medida em que os Estados começaram a perceber outros temas, que não aqueles voltados para suas forças armadas, como capazes de causar sérios danos ao país, tanto as agendas de pesquisa quanto as pautas políticas passaram por um processo de reforma, que implicou em grandes controvérsias metateóricas.

Mesmo as correntes mais tradicionais do campo buscaram rever algumas de suas teses, incorporando novas dimensões às análises produzidas. Desta forma, no início dos anos 1990 já era possível identificar alguns processos de transformação nos estudos de segurança, entre eles: (1) houve maior abertura para as ciências sociais, o que criou espaço, principalmente, para um debate sobre métodos; (2) as leituras históricas foram recuperadas e se tornaram um traço fundamental, transcendendo o período da Guerra Fria, permitindo a proliferação de estudos comparativos e servindo como base para o teste de proposições teóricas; (3) este campo ganhou espaço nas universidades, o que permitiu a produção de conhecimento em ambientes menos ligados ao Estado e sem objetivos explícitos de influenciar a formulação de políticas (como ocorria com os think tanks); (4) houve a proliferação de revistas acadêmicas e publicações sobre o tema, o que aumentou a visibilidade do campo e o diálogo entre os pesquisadores (Lyn-Jones, 1991).

Assim, no que tange aos debates ${ }^{72}$ do campo de segurança internacional neste período, é possível dividir as argumentações em três correntes ${ }^{73}$ :

\footnotetext{
${ }^{72}$ É importante notar que o uso do termo "debate" pode não ser o mais adequado para se referir às diferentes agendas de pesquisa do campo, uma vez que, segundo alguns autores, não há interesse, principalmente por parte dos neorealistas, em engajar com os argumentos críticos (C.A.S.E Collective, 2006; Buzan et al, 1998; Wæver, 2004) Assim, percebe-se uma maior interação dentro dos dois grupos (positivistas e pós-positivistas) do que entre eles.

${ }^{73}$ Esta divisão, no entanto, não é consensual. Em outro momento, o próprio Buzan apresenta um quadro multifacetado dos estudos segurança, no qual inclui onze grupos. De acordo com Buzan e Hansen (2009), estes seriam: construtivismo convencional, construtivismo crítico, a Escola de Copenhague, os estudos críticos de segurança, estudos feministas de segurança, segurança humana, pesquisas sobre a paz, estudos pós-colonialistas de segurança, estudos pós-estruturalistas de segurança, estudos estratégicos e (neo)realismo. Esta abordagem é mais fiel aos diferentes argumentos dos autores que trabalham com este campo, mas tem um poder de síntese bastante reduzido.
} 
“tradicionalistas", “críticos ${ }^{74 "}$ e "abrangentes ${ }^{75 "}$ (Buzan, 1997). Duque (2009) resume as bases da divisão apresentada por Buzan esclarecendo que:

“(i) a tradicionalista: (a) enfatiza o uso da força e as questões militares; (b) analisa as ameaças à segurança a partir de uma perspectiva objetivista [...]; e (c) é estado-cêntrica. (ii) a vertente crítica, considera que as ameaças e objetos de segurança são socialmente construídos. [...] os acadêmicos possuem o papel de mostrar construções sociais diferentes e, dessa forma, emancipar os indivíduos; e (iii) a vertente abrangente [...] defende: (a) o alargamento do conceito de segurança, com base na existência de ameaças não militares e (b) a redefinição do significado de segurança como ato de fala [...]" (Duque, 2009, p. 11, grifo do autor).

Esta classificação se traduz também em termos geográficos, refletindo uma dicotomia entre as teorias dominantes nos Estados Unidos, ainda com forte caráter positivista, e aquelas mais influentes na Europa, com predominância do reflexivismo (Wæver, 1998). Enquanto a academia norte-americana está voltada para o debate entre as diversas correntes realistas (ofensivos, defensivos, neorealistas e realistas neoclássicos) e liberais (trazendo temas como a paz democrática), os autores europeus se mostram mais preocupados com questões de identidade, relação Estado/sociedade e o processo de construção social das políticas de segurança.

A divisão é, em grande medida, um reflexo dos diferentes legados teóricos incorporados pelos "tradicionalistas" e seus críticos. Enquanto o primeiro grupo importa modelos matemáticos e econométricos (Jervis, 1978), valendo-se destes para desenvolver argumentos sobre a dissuasão e o comportamento dos Estados

\footnotetext{
${ }^{74}$ O uso do termo "crítico" segue a terminologia empregada por Krause e Williams no livro "Critical Security Studies", de 1997. Ao organizar esta publicação, os autores não procuraram delimitar o conceito, mas sim apresentar o amplo campo de teorias que se opunham às vertentes tradicionais que dominavam a área. Assim, partiram do pressuposto de que "[...] security studies has been among the last bastions of orthodoxy in International Relations to accept critical or theoretically sophisticated challenges to its problematic" (Krause \&Williams, 1997, p.vii). Deste modo, optaram por apresentar uma gama de estudos com premissas e temáticas distintas entre si e que tivessem em comum o simples fato de contribuir para a pluralidade teórica no campo. Justamente por isso, Krause e Williams não tiveram a preocupação de definir à priori um significado preciso para "crítico", deixando para cada autor formular suas críticas às correntes vigentes de forma bastante livre (Krause \& Williams, 1997).

${ }^{75}$ Trata-se de uma tradução do termo exato empregado por Buzan (wideners). A versão em inglês é mais comumente utilizada na área, mesmo por autores não anglófonos. Ao longo da dissertação o termo também é traduzido para mencionar o fenômeno de "ampliação" da agenda de segurança.
} 
(Lebow, 1983/4), os estudos críticos sofrem influência de um leque maior de disciplinas, incorporando: linguísitica (Wæver, 1998; Fierke, 2007), teoria social (Hansen, 2000; Bigo, 2002; Huysmans, 2006), teoria política (Walker, 1993), póscolonialismo (Ayoob, 1995; Muppidi, 2004) e feminismo (Tickner, 2004). Desta forma, o segundo grupo opera no sentido de diminuir o insulamento da área de segurança, buscando subsídios teóricos e metodológicos de outros campos e promovendo o engajamento dos diversos autores com uma literatura até então ignorada.

Tabela 4: Contraste entre estudos de segurança nos EUA e na Europa

\begin{tabular}{|l|l|}
\hline USA & Europe \\
\hline $\begin{array}{l}\text { Concept of security not interesting (only } \\
\text { delineation) }\end{array}$ & $\begin{array}{l}\text { Concept of security as continued centre of } \\
\text { reflection }\end{array}$ \\
\hline General IR theories applied and competing & Specific theorising about security \\
\hline Narrow military focus & Broad econ-political approach \\
\hline $\begin{array}{l}\text { Rationalists theories; but in soft version often } \\
\text { using historical case studies }\end{array}$ & Degrees of reflectivism/constructivism \\
\hline $\begin{array}{l}\text { Instrumental knowledge to assist in handling } \\
\text { policy tasks }\end{array}$ & $\begin{array}{l}\text { General reflection as part of political process } \\
\text { in society on fundamental questions of self- } \\
\text { definition and self-shaping }\end{array}$ \\
\hline
\end{tabular}

\subsubsection{Diversidade nos estudos de segurança: tradicionalistas e as escolas críticas}

Stephen Walt (1991), expoente do grupo "tradicionalista", afirma ser um desserviço para a academia tratar novos temas segundo a lógica da segurança, indicando que tal fato geraria uma ampliação tão grande da área que o conceito perderia qualquer valor explicativo. Para o autor, o que define o campo é "the study of the threat, use, and control of military force" (Walt, 1991, p. 212), ou seja, o foco é nas condições que tornam o conflito uma alternativa política, seu impacto nos Estados, e as possíveis formas de evitar sua recorrência. Assim, Walt argumenta que, ao afastar-se das questões militares, os analistas correm o risco de expandir excessivamente os estudos de segurança e, por essa lógica: 
"[...] issues such as pollution, disease, child abuse, or economic recessions could all be viewed as threats to 'security'. Defining the field in this way would destroy its intellectual coherence and make it more difficult to devise solutions to any of these important problems" (Walt, 1991, p. 212-213).

Do mesmo modo, John Chipman (1992), um influente neorealista, defende que:

"The structuring elements of strategic analysis must be the possible use of force. [...] Non-military aspects may occupy more of the strategist's time, but the need for peoples, nations, states or alliances to procure, deploy, engage or withdraw military forces must remain a primary purpose of the strategic analyst's inquires" (Chipman, 1992, p. 129).

Indo além, Lebow (1988) defende que a contribuição normativa de estudos interdisciplinares seja considerada pela área, principalmente se forem possíveis aliados na formulação de recomendações às políticas estatais. No entanto, o autor afirma que a agenda de pesquisa deve ser restrita, estando direcionada a três objetivos: identificar as causas das guerras, formular estratégias e mecanismos que possam reduzir o risco da guerra e persuadir os líderes mundiais a adotarem seus conselhos (Lebow, 1988). Assim, Lebow mantém-se na lógica dos estudos estratégicos, subordinando os debates teóricos à formulação de políticas de segurança.

Por outro lado, teóricos "críticos" e "abrangentes" afirmam que seria possível estender o conceito sem que seu conteúdo deixasse de ser academicamente relevante. Segundo Krause \& Williams (1996):

\footnotetext{
"What unites these efforts is a conviction that the neorealist focus on safeguarding the 'core values' of a state from military threats emanating from outside its borders is no longer adequate (if it ever was) as a means of understanding what (or who) is to be secured, from what threats, and by what means. The theoretical targets being debated are the conceptualizations of security (state security) and threat (military force) and the assumption of anarchy (the security dilemma) that have characterized neorealist scholarship in security studies" (Krause \& Williams, 1996, p. 230)
} 
Trata-se, portanto, de uma compreensão distinta acerca do campo de estudos, que rejeita muitos dos pressupostos neorealistas e, consequentemente, busca novas agendas de pesquisa ${ }^{76}$. Assim, abre-se espaço para autores que não denotam ao conceito de segurança um valor absoluto e indivisível, mas que o veem como fruto de uma construção social, moldado pelas percepções que os diversos atores tenham sobre ele (Wæver, 1995; Buzan et al, 1998; Fierke, 2007; Bilgin, 2008).

De acordo com estas correntes, não seria mais possível ignorar os constrangimentos internos à segurança, muito menos os agentes transnacionais que ajudam a determinar a natureza das relações de poder no mundo e, por conseguinte, as políticas de defesa. Desta forma, apresenta-se uma abordagem construtivista na definição do objeto de pesquisa, que seria pautada não por interesses existentes a priori, mas sim pelas diferentes interpretações acerca de ameaças, de modo que:

"[...] rather then treating states, groups or individuals as givens that relate objectively to an external world of threats created by the security dilemma, these approaches stress the processes through which individuals, collectivities and threats become constructed as 'social facts' and the influence of such constructions on security concerns" (Krause \& Williams, 1996, p. 242).

Estes autores propõem que se pense o campo da segurança como um espaço de contestação política, e deste movimento decorre uma mudança fundamental. Segundo Fierke (2007):

"From the acknowledgement that security is, in several aspects, political, flows a further acknowledgment that its meaning can change as it becomes a subject of contestation. [...] The meaning and study of security is always political, that is, always defined within a political context and subject to normative debate and change" (Fierke, 2007, p. 15)

\footnotetext{
${ }^{76}$ É fundamental ressaltar que entre os "abrangentes" a diversidade é a regra, não a exceção. Como será visto adiante, mesmo entre os autores da Escola de Copenhague, há divergências importantes. Assim, o que permite unir conceitualmente este grupo é somente a crítica aos postulados neorealistas, não suas concepções teóricas.
} 
Partindo desta interpretação da área, Fierke desenvolve o conceito de "security clusters 77 ", que engloba algumas das questões também levantadas pelos demais autores. Trata-se da percepção de um campo relacional mais poroso, onde a ameaça e o objeto não são entendidos separadamente, mas dentro de um contexto político socialmente construído. A ideia de "security clusters" vai exatamente na direção de criticar o isolamento de determinada dimensão da área de segurança, analisando múltiplos relacionamentos que estão envolvidos na produção das ameaças. Nas palavras da autora, "Rather then constructing a hierarchy of threats, it requires a rethinking and a mapping of the relationships that constitute various threats to human life" (Fierke, 2007, p. 52).

Frente às críticas apresentadas, o monopólio do positivismo na área de segurança ruiu rapidamente (Buzan, 1991). Apesar de esta corrente ainda ser fundamental para a disciplina, ao longo da década de 1990 muitos analistas reconheceram a necessidade de formular novas linhas de pesquisa capazes de incorporar uma gama distinta de fatores na compreensão dos temas de segurança internacional $^{78}$.

Visando a facilitar o entendimento do estado da arte dos estudos de segurança, convencionou-se dividir as críticas ao neorealismo segundo três grupos $^{79}$ : Escola do País de Gales (ou Escola de Aberystwyth), Escola de Copenhague e Escola de Paris ${ }^{80}$ (Williams, 2008).

Sendo a Europa ocidental a região que experimentou o mais alto grau de integração política, emergindo como um subsistema em que conflitos interestatais foram praticamente riscados da lista de possíveis ameaças, não é de se espantar que as três vertentes tenham surgido neste continente (Wæver, 2000). Segundo

\footnotetext{
${ }^{77}$ Conceito utilizado em inglês, pois perde muito de seu significado com a tradução ao português. Feita esta ressalva, a versão mais próxima seria "agrupamento de segurança".

${ }^{78}$ Fato que fica claro quando a revista "Survival", uma das mais representativas da área, apresenta, em 1989 (Vol. 31), um número especial voltado apenas para ameaças não-militares à segurança.

79 Estes grupos correspondem às abordagens "críticas" e "abrangentes" mencionadas anteriormente, sendo um recorte mais específico para identificar os diferentes argumentos que se contrapõe à vertente neorealista.

${ }^{80}$ Apesar de a categorização dos diferentes argumentos a partir da noção de "escolas" ser problemática (C.A.S.E. Collective, 2006), esta terminologia é largamente utilizada na academia. Esta ressalva é especialmente importante ao tratar da "Escola de Paris", uma vez que os próprios autores inseridos nesta escola recusam o rótulo. No entanto, há a preocupação em não homogeneizar os diferentes autores, demonstrando que os argumentos divididos segundo padrões gerais ainda guardam importantes diferenças.
} 
Wæver, a construção de uma comunidade de segurança ${ }^{81}$ a partir do processo de criação da União Europeia foi fundamental para o desenvolvimento das críticas aos "tradicionalistas", uma vez que os Estados não se percebiam dentro de uma lógica clássica de segurança ${ }^{82}$, mas mantinham seus aparatos de vigilância e receios em relação a diversos fenômenos nos ambientes externo e doméstico.

As três escolas tem em comum a crítica às limitações teóricas do neorealismo. Entretanto, a proposta de ampliação/aprofundamento da agenda de segurança e a veia construtivista são dos poucos aspectos que unem estas abordagens. O quadro analítico destes três grupos é bastante distinto: os autores da Escola do País de Gales, formulada, em sua maioria, por pesquisadores da Universidade de Aberystwyth, focam seus trabalhos no conceito de emancipação, apontando o Estado como um dos principais perpetradores da violência; a Escola de Copenhague desenvolve o conceito de "securitização" e uma nova forma de enxergar a construção de ambientes de conflito e momentos de exceção; e a Escola de Paris, propõe um enfoque sociológico e busca construir o objeto do campo segundo práticas diárias de segurança (Williams, 2008).

Os pesquisadores de Aberystwyth, especialmente Booth e Wyn Jones, recuperam alguns dos questionamentos levantados pelos estudos de paz nos anos 1960 e 1970, reintroduzindo no debate de segurança os argumentos de outra escola, a de Frankfurt ${ }^{83}$. Incorporando as obras de Theodor Adorno e Max Horkheimer, denuncia-se a falsa neutralidade do neorealismo e argumenta-se que o processo de construção de conhecimento é sempre determinado por interesses diversos, o que transforma o autor, obrigatoriamente, em um agente político. Indo além, ao trabalhar com o conceito de emancipação evidencia-se a alienação do indivíduo como objeto referencial. Nesse sentido, Booth (1991) apresenta o projeto de pesquisa da Escola do País de Gales da seguinte forma:

“'Security' means the absence of threats. Emancipation is the freeing of people (as individuals and groups) from those physical and human constraints which

\footnotetext{
${ }^{81}$ Para mais sobre o debate teórico acerca da construção de comunidades de segurança, ver: "Security Communities" (1998) de Emanuel Adler e Michael Barnett.

${ }^{82}$ Nas palavras do autor: "Classical political concerns appear but are mostly conceived for 'Europe' not individual states" (Wæver, 2000, p. 69).

${ }^{83}$ Grupo de intelectuais, em sua maioria ligados à Universidade de Frankfurt nos anos 1930, preocupados com a transformação social e o papel do produtor de conhecimento na sociedade. Este grupo ficou identificado com o marxismo e a sociologia crítica, tendo como principais nomes, Adorno, Horkheimer, Marcuse, Fromm e, posteriormente, Habermas.
} 
stop them carrying out what they would freely choose to do. War and the threat of war is one of those constraints, together with poverty, poor education, political oppression and so on. Security and emancipation are two sides of the same coin. Emancipation, not power or order, produces true security. Emancipation, theoretically, is security" (Booth, 1991, p. 319).

Defendendo um redirecionamento do foco das políticas de segurança - dos Estados para os indivíduos - estes autores tiveram influência efetiva na formulação da política externa de muitos países europeus e sensível impacto na transformação dos padrões de atuação das Nações Unidas nos anos $1990^{84}$ (Booth, 2005; Relatório Brahimi, 2000). Apesar disso, esta escola não será abordada diretamente ao longo da dissertação ${ }^{85}$. Esta corrente produziu uma bibliografia no que tange à política europeia para imigração ${ }^{86}$ (Rees, 2009), mas os autores pouco utilizam a lógica da emancipação para debater sobre os possíveis impactos da criação de agências de segurança na União Europeia. Assim, o processo de criação e fortalecimento da Frontex é um objeto de análise mais próximo das demais escolas, que interpretam de diferentes maneiras os descaminhos da política comum para o controle de fronteiras.

Deste modo, cabe analisar mais pausadamente o desenvolvimento institucional da Escola de Copenhague e a forma como diversos autores se valeram do quadro analítico criado por Wæver e Buzan para explicar a formulação da política integrada de gerenciamento de fronteiras e, especificamente, as ações da Frontex. A crítica da Escola de Paris a esta leitura será o tema dos capítulos seguintes.

Tabela 5: As escolas europeias de segurança, suas semelhanças e particularidades

\footnotetext{
${ }^{84} \mathrm{O}$ que se revela em um novo e ativo papel desempenhado pelo Conselho de Segurança a partir dos anos 1990. Para mais sobre essa discussão, ver Macfarlane et al, 2006.

${ }^{85}$ A Escola do País de Gales se baseia numa agenda de pesquisa na qual o Estado é um meio e não um fim para a segurança dos indivíduos. Assim, apesar de seguir algumas das premissas construtivistas apresentadas por Buzan et al, estes autores os criticam por manter alijada a discussão sobre segurança humana, reproduzindo a lógica estadocêntrica (Booth, 2005) - o que, de fato, ocorre nos primeiros trabalhos de Buzan (1983), mas não se mantém como um elemento central para os demais autores da Escola de Copenhague.

${ }^{86}$ Além do mencionado texto de Wyn Rees, pode-se ressaltar: "Gender, Migration and Social Change" (1991) de Tienda e Booth; e "Human security and the protection of refugees" (2003) de Suhrke.
} 


\begin{tabular}{|c|c|}
\hline Groups of authors & Basic arguments \\
\hline Aberystwyth & $\begin{array}{l}\text { - Widening } \\
\text { - Emancipation } \\
\text { - Social construction of threats; self/other relations }\end{array}$ \\
\hline Copenhagen & $\begin{array}{l}\text { - Securitisation: the political construction of security issues } \\
\text { - Desecuritisation; 'security' is not good but at best a minor evil, } \\
\text { while most often our aim should be to limit the rhetoric of security and } \\
\text { its accompanying politics of exception and emergencies } \\
\text { - Distinguish between securitizing actors and referent objects }\end{array}$ \\
\hline Paris & $\begin{array}{l}\text { - Internal and external security merge } \\
\text { - Security agencies } \\
\text { - Praxis over discourse }\end{array}$ \\
\hline Shared & $\begin{array}{l}\text { - Reflections on the concept of security as such, i.e. as interesting in } \\
\text { itself and not only a matter of delineation and pre-analytical definition } \\
\text { - Concern with the issue of possible widening as contradictory and } \\
\text { political } \\
\text { - Security as practice } \\
\text { - Self-reflection: one's own practice as security analyst is implicated } \\
\text { in the politics of security, and as such one face hard ethical dilemmas } \\
\text { as security actor }\end{array}$ \\
\hline
\end{tabular}

(Wæver, 2004, p. 11-12)

\subsection{Contribuições da Escola de Copenhague aos estudos de Segurança Internacional}

O processo de institucionalização de determinado campo de estudos tem impacto decisivo no modo como este se desenvolverá e abordará eventos políticos contemporâneos. As formas pelas quais se dão (1) a construção das estruturas organizacionais (departamentos, centros de pesquisa, think tanks), (2) a alocação de recursos dentro das universidades ou a partir de agências estatais de fomento, (3) a disseminação de conhecimento e (4) a formulação de redes de pesquisa são elementos fundamentais para a construção de determinada comunidade acadêmica (Buzan \& Hansen, 2009). A distribuição de recursos, por exemplo, influencia as dinâmicas burocráticas dos departamentos e, fundamentalmente, incentiva a reprodução de determinada área de conhecimento em detrimento de outra. Assim, alguns aspectos da institucionalização dos campos de estudos, como o regimento interno das universidades e a constituição das redes de pesquisadores, contribuem para a inércia, o que se reflete na manutenção de determinadas posturas teóricas. No entanto, há elementos que exercem o efeito oposto (por exemplo, transformações nos programas de financiamento), acelerando mudanças nas comunidades acadêmicas. 
Nesse sentido, é fundamental analisar a forma pela qual a Escola de Copenhagen se desenvolveu, compreendendo o contexto político e institucional em que os argumentos de Wæver e Buzan foram formulados, publicados e disseminados.

\subsubsection{Instituto de Pesquisas para a Paz de Copenhague}

O desenvolvimento da Escola de Copenhague, cujo principal patrocinador foi o próprio governo dinamarquês, se deu em meio à formulação da Política Externa e de Segurança Comum (PESC) da UE. Por anos, a comunidade europeia debateu sobre a necessidade de uma estratégia de defesa que a protegesse da ameaça soviética e garantisse sua autonomia em relação aos Estados Unidos. Contudo, entre os líderes europeus reunidos na cidade de Maastricht, em 1992, havia a percepção de que uma guerra interplanetária não era mais a principal ameaça ao continente ${ }^{87}, \log$, a demanda por cooperação neste campo não só perdeu o caráter de urgência, como teve seu conteúdo modificado.

Além disso, o início da década de 1990 foi um período de multiplicação de movimentos sociais na Europa. Organizados em torno de "novos" temas ${ }^{88}$, estes movimentos passaram a pressionar pela ampliação e transformação da agenda política, cobrando dos governos uma abordagem mais séria para questões como a proteção do meio ambiente e a promoção de direitos civis. Estes grupos foram capazes de angariar apoio de certas camadas da elite política europeia e, aos poucos, passaram a influenciar de maneira bastante significativa o processo de tomada de decisão.

Neste cenário, as negociações em Maastricht não foram capazes de unir interesses e articular respostas supranacionais aos desafios de segurança militar, o

\footnotetext{
${ }^{87}$ A questão nuclear agora era voltada para as ameaças geradas pela proliferação. Devido à falta de controle sobre os antigos arsenais soviéticos, o processo de desnuclearização dos novos países da Europa do leste se tornou uma prioridade. Além disso, havia um enorme receio de que algumas ogivas pudessem ser adquiridas por grupos para-militares ou regimes radicais islâmicos (Garnett, 1997).

${ }^{88}$ Entre estes movimentos, os que obtiveram mais sucessos neste período foram os ambientalistas. As ações em defesa do meio ambiente, muitas vezes arriscadas, foram amplamente divulgadas pela mídia europeia, aumentando a penetração destes grupos na sociedade e, por consequência, sua influência política.
} 
que resultou em um diálogo bastante limitado entre as forças $\operatorname{armadas}^{89}$. Não obstante, o tratado assinado apresentou avanços importantes nos temas de proteção ao meio ambiente, direitos de homossexuais, igualdade racial, questões de gênero, ajuda humanitária, práticas comerciais, medidas econômicas, políticas sociais e políticas de imigração, refletindo o impacto dos movimentos civis na opinião pública europeia (Watson \& Shackleton, 2003).

A crescente cooperação nestes temas evidencia o espaço que questões de segurança não tradicionais já ocupavam na Europa. Mais que novas estratégias, estes movimentos ofereciam novas abordagens, partindo do questionamento central sobre quem teria direito de decidir objetivamente sobre o que é "segurança" e, em última análise, sobre a vida e a morte de indivíduos. Esta motivação política encontrava eco no ambiente acadêmico, sendo uma inquietação também dos teóricos críticos do campo (Buzan, 1991).

No caso da Dinamarca, outro elemento desempenhou um papel importante: a tradição "pacifista". Desde os anos 1950, grupos descontentes buscavam ressaltar que as políticas da OTAN não representavam os valores da sociedade dinamarquesa. No final dos anos 1980, os resultados eleitorais contribuíram para uma grande representação parlamentar desta voz, dificultando a adoção por parte do governo de uma política externa próxima aos demais países da aliança militar e gerando grandes controvérsias acerca da definição de quais seriam as ameaças à "segurança nacional”. A criação do Instituto de Pesquisas para a Paz de Copenhague (1985) se deu no bojo deste debate, sendo um espaço onde questões da segurança europeia seriam pensadas e discutidas (Tanno, 2002).

A história institucional não deve, contudo, ser tomada como espelho do processo de desenvolvimento dos argumentos que ampliavam agenda de segurança. Em 1985, Buzan, por exemplo, já publicara a primeira edição de "People, States and Fear" (1983), e começava a elaborar alguns dos conceitos que se tornariam paradigmas da Escola. $\mathrm{O}$ que a criação do instituto evidencia é a conexão que o debate acadêmico tinha com o espaço formal da política partidária, conexão esta que serviu não somente para justificar mudanças na prática do

\footnotetext{
${ }^{89}$ Esta diferença se reflete no desenho institucional da União Europeia. Optou-se por três pilares: políticas comunitárias, a PESC e Justiça e Assuntos Internos (JAI), estas últimas marcadamente intergovernamentais.
} 
governo dinamarquês, mas também para divulgar os argumentos destes autores entre a comunidade acadêmica ${ }^{90}$.

A Escola de Copenhague só passou a ser conhecida (e referida) como tal após a publicação do ensaio crítico de Bill McSweeney, "Identity and security: Buzan and the Copenhagen school", em 1996. Este ensaio abriu espaço para um debate que resultou na publicação de outros três $\operatorname{artigos}^{91}$ em 1998, todos na Review of International Studies, debatendo as raízes, contradições e equívocos das pesquisas produzidas pelo instituto dinamarquês.

Dentre muitos, Buzan e Wæver, por terem formulado uma nova ferramenta analítica, foram os pesquisadores que receberam mais atenção na Escola de Copenhague. Seu livro "Security: A New Framework for Analysis" (1998), escrito com a colaboração de Jaap de Wilde, define e desenvolve o conceito de "securitização", apresentando uma nova forma de se pensar a respeito das políticas de defesa, com ênfase no processo de construção das ameaças. Partese do pressuposto que os temas de segurança não são estáticos, mas dependem da forma como a elite política interpreta e constrói os diversos fenômenos. Desta maneira, propõe-se que a agenda de pesquisa seja abrangente, cobrindo os inúmeros temas que, aos poucos, começavam a ser incluídos nos programas de segurança dos Estados. No título do livro já fica claro que se trata de uma proposta de quadro analítico - não necessariamente um argumento normativo mais adequado para compreender o comportamento dos governos e os ambientes de conflito.

A abordagem de Wæver e Buzan representou uma importante contribuição à área, sendo logo disseminada entre a literatura sobre estudos de segurança. Desde então, muitos dos debates metateóricos no campo giram em torno da ideia de securitização, valendo-se dela para analisar determinado fenômeno ou criticando-a como abordagem de pesquisa. Fato é, que, para muitos, o largo uso deste conceito tem gerado análises pouco atentas e, por vezes, equivocadas sobre

\footnotetext{
${ }^{90}$ Para mais detalhes acerca da criação do instituto e sua influência para a os estudos de segurança ver Pedersen (1989) e Tanno (2002).

${ }^{91}$ Estes foram: (1) Buzan, B. e Wæver, O. "Slippery? contradictory? Sociologically unstable? The Copenhagen school replies". Review of International Studies, 23:2, 1998, pp. 143-152. (2) McSweeney, B. "Durkheim and the Copenhagen school: A response to Buzan and Wæver". Review of International Studies, 24:1, 1998, pp. 137-140. (3) Williams, M. "Comment on the 'Copenhagen controversy'. Review of International Studies, 24:3, 1998, pp. 435-441. Para mais, ver
} 
os mais diversos cenários políticos (Balzacq, 2008). Faz-se, portanto, fundamental um estudo mais detalhado das premissas da Escola de Copenhague.

\title{
2.2.2. O quadro analítico da Escola de Copenhague
}

Os primeiros trabalhos desta Escola, especialmente os de Buzan (1983, 1991), eram ainda bastante comedidos em suas proposições críticas aos estudos tradicionais de segurança. Na medida em avançava uma perspectiva positivista acerca da compreensão das ameaças, afirmando que estas existiam descoladas da interpretação dos agentes políticos, e pautava suas análises nas ameaças ao Estado, tendo este como objeto referencial único, Buzan mantinha-se alheio às críticas ao cientificismo e reducionismo do campo. Sua contribuição às correntes abrangentes fica evidente apenas na reedição do livro "People, States and Fear", quando o subtítulo passa a ser "An Agenda for International Security Studies in the Post-Cold War Era ${ }^{92}$ ". Nesta releitura de seus próprios argumentos, Buzan mantém o foco no Estado, mas defende que não são apenas questões militares que acabam compreendidas como ameaças, mas também outros fenômenos sociais. Para o autor:

\begin{abstract}
"Security is primarily about the fate of human collectivities and only secondarily about the personal security of individual human beings. In the contemporary international system, the standard unit of security is thus the sovereign territorial state" (Buzan, 1991, p. 19).
\end{abstract}

Apesar desta autocrítica, Buzan não rompeu com as bases positivistas. Deste modo, o substrato teórico do construtivismo reflexivo ${ }^{93}$, para o qual segurança é uma condição derivada da habilidade dos Estados de manterem suas identidades sociais e integridades funcionais, só foi incorporado a esta Escola graças a obra de outro autor.

\footnotetext{
${ }^{92}$ O subtítulo original "The National Security Problem in International Relations", já revelava os argumentos pouco críticos do autor.

${ }^{93}$ É válido ressaltar a grande diferença entre o construtivismo positivista de Wendt, utilizado por Buzan, e o construtivismo reflexivo (pós-positivista) que Wæver traz para sua abordagem. Apesar de ambos terem organizado a obra seminal para os estudos de securitização juntos, estes autores apresentam perspectivas teóricas com divergentes. É justamente esta distinção que será mostrada a seguir.
} 
Sendo um dos trabalhos recentes mais citados nesta área de estudos, "Securitization and Desecuritization" (1995), de Wæver, traz uma abordagem teórica que o afasta definitivamente dos debates tradicionais no campo. Neste $\operatorname{artigo~}^{94}$, Wæver afirma ser necessário pensar o conceito de segurança como um contínuo - um inesgotável processo de construção - e não a partir de uma lógica pré-definida.

Para o autor, os positivistas, sejam eles neorealistas ou liberais, partilham de uma concepção básica: a crença de que "segurança" existe por si só, sendo uma realidade anterior à linguagem. Consequentemente, este grupo aceita de forma inconteste um suposto conteúdo original do conceito, aplicando-o de forma acrítica em leituras sobre os variados campos da vida social. Wæver rompe com esta visão ressaltando a importância de se trabalhar com a ideia de segurança a partir de sua perspectiva histórica, e salientando que conceitos são formulados por alguém e para determinado fim. Este exercício de historicização está no centro da abordagem de Wæver, que demanda também uma redefinição de foco - do Estado para a sociedade.

Buscando uma síntese entre o trabalho destes dois autores, é possível afirmar que a Escola de Copenhague propõe que se desenvolvam estudos ainda à luz do Estado - tendo este como um de seus principais atores -, mas englobando as diferentes dinâmicas que afetem a disseminação da lógica de segurança. Ou seja, a abrangência do conceito se dá segundo a compreensão de que a "segurança" tem um campo de práticas único, com significados específicos e dinâmicas próprias, e que estes, por vezes, podem ser construídos a partir de questões não tradicionais (Wæver, 1995). Assim, ao mesmo tempo em que desconstrói a noção de um espaço pré-social de segurança - operando uma virada ontológica -, esta escola também nega que a expansão deste espaço deva ocorrer através dos parâmetros tradicionais.

O centro desta argumentação está no mecanismo de produção/percepção das ameaças existenciais, definidas como: "something that can undercut the political order within a state and thereby 'alter the premises of all other questions"” (Wæver, 1995, p. 52). Assim, as questões militares ainda seriam centrais, pois há um consenso de que a derrota em uma batalha pode impedir o

\footnotetext{
${ }^{94}$ Parte da tese de doutorado de Wæver que foi publicada como um capítulo no livro "On Security" (1995), editado por Ronnie Lipschutz.
} 
Estado de manter sua soberania e levar à imposição das vontades do conquistador. Porém, este mesmo consenso já existe em torno de questões de outra natureza. Há um entendimento de que a subversão da ordem pode ocorrer por motivos diversos - catástrofes naturais, crises financeiras, epidemias - o que também os torna ameaças à segurança. Para compreender a formação destes novos consensos, Wæver afirma que os estudos críticos devem trabalhar com a lógica da interação e dos discursos, percebendo-os como gatilhos para a produção intersubjetiva de significados. E é justamente ao processo de produção de significados de segurança que o autor dá o nome de "securitização".

Há, portanto, uma ruptura com as bases dos estudos tradicionais. Ao invés de compreender as questões de segurança como sendo objetivas - ameaça física ao Estado -, os teóricos de Copenhague afirmam que qualquer assunto pode ser construído como um tema de segurança, sendo necessário apenas que este seja entendido como uma ameaça existencial. Deste modo, abrem-se novos espaços (ou setores) onde as políticas de segurança podem operar. É válido lembrar que ao introduzir este debate, não se está ignorando o campo de práticas de segurança já enraizado (a segurança nacional), mas sim, argumentando que a mesma lógica pode ser percebida em outras dimensões sociais. Historicamente, o setor militar tem sido o objeto de análise mais comum do campo, mas questões ambientais, de soberania e identidade também podem ser trabalhadas a partir dos mesmos padrões. Portanto, deve-se construir “[...] a more radical view of security studies by exploring threats to referent objects, and the securitization of those threats, that are non-military as well as military" (Buzan et al, 1998, p. 4).

Deste modo, pode-se dizer que o quadro analítico apresentado é composto pelos seguintes elementos: a percepção de uma "existential threat to a referent object by a securitizing actor who thereby generates endorsement of emergency measures beyond rules that would otherwise bind" (Buzan et al, 1998, p. 5, grifo nosso). Ou seja, considera-se que a agenda política dos Estados está sujeita a transformações, nas quais os mais variados temas podem ser vistos segundo o contínuo de segurança, sendo "não-politizados", "politizados" ou "securitizados", dependendo da prioridade dos mesmos em meio à sociedade. Esta mudança se daria graças ao esforço de agentes políticos ${ }^{95}$ em apresentar determinados

\footnotetext{
${ }^{95}$ Trata-se de um indivíduo ou grupo capaz de proferir os atos de fala acerca dos significados de segurança. É fundamental o espaço que este ator ocupa na sociedade, pois apenas a partir de um
} 
fenômenos como ameaças ou não. Um processo de securitização estaria completo no momento em que os discursos ("speech acts") acerca da ameaça existencial fossem aceitos pela sociedade, habilitando os governantes a fazerem uso de políticas emergenciais para lidar com os desafios identificados ${ }^{96}$.

O caráter de emergência é central para a definição de contextos de segurança. Trata-se da demanda por ações especiais que superem as barreiras da deliberação política, pois se considera que determinada ameaça seja existencial e precise de respostas urgentes. Este aspecto será retomado ao longo da dissertação, no momento, cabe apontar que, nas palavras dos autores:

' 'Security' is the move that takes politics beyond the established rules of the game and frames the issues either as special kind of politics or as above politics. [...] In theory, any public issue can be located on the spectrum ranging from nonpoliticized (meaning the state does not deal with it and it is not in any other way made an issue of public debate and decision) through politicized (meaning the issue is part of public policy, requiring government decision and resource allocations or, more rarely, some other form of communal governance) to securitized (meaning the issue is presented as existential threat requiring emergency measures and justifying actions outside the normal bound of political procedure). (Buzan et al, 1998, p. 23-24).

Desta forma, o quadro analítico demanda uma metodologia de estudo baseada em discursos e seus contextos políticos. Foca-se no ator securitizante, aquele que define determinado objeto segundo a lógica de segurança, mas também na audiência a quem o discurso é endereçado. Nesse sentido, trata-se de uma prática auto-referente, pois é ao falar em termos de segurança que o assunto ganha esta conotação. Não há, portanto, um debate sobre a existência objetiva ou não da ameaça. Hipóteses sobre materialidade e metodologias de acesso à realidade não tem espaço nesta literatura. A agenda da Escola, especialmente a contribuição de Wæver, é hermenêutica, voltada para o estudo sobre como a

papel social de destaque seu argumento terá repercussão em meio ao público (Wæver, 1995). Assim, a Escola de Copenhague volta suas análises para líderes políticos específicos e grupos de pressão (lobby).

${ }^{96}$ Wæver desenvolve seus argumentos sobre a relevância do conceito de speech act baseado nos trabalhos do filósofo inglês John Austin. Para mais sobre a influência de Austin na Escola de Copenhague e as origens do conceito de Speech act, ver Wæver (1989) e Taureck (2006). 
mensagem é produzida e captada pelos agentes sociais. Para tanto, Wæver recupera o conceito de "atos de fala", definindo-o da seguinte forma:

"In security discourse, an issue is dramatized and presented as an issue of supreme priority; thus, by labeling it as security, an agent claims a need for and a right to treat it by extraordinary means. For the analyst to grasp this act, the task is not to assess some objective threats that 'really' endanger some object to be defended or secured; rather, it is to understand the process of constructing a shared understanding of what is to be considered and collectively responded to as a threat. The process of securitization is what in language theory is called a speech act. It is not interesting as a sign referring to something more real; it is the utterance itself that is the act. By saying the words, something is done (like betting, giving a promise, naming a ship)" (Buzan et al, 1998, p. 26).

Esta ferramenta permite a identificação de lógicas específicas de segurança em diferentes esferas da sociedade. É possível, portanto, aplicá-la a inúmeros contextos políticos, nos quais o objeto referente (o que é ameaçado) revela-se em uma variedade de fenômenos.

Conforme visto, no início dos anos 1990, Buzan (1991) ainda trabalhava com um grupo fechado de objetos de análise. Imerso no debate entre "tradicionalistas" e "abrangentes", este autor se limitava a apontar alguns poucos processos em que a sociedade era o objeto da ameaça, sendo esta capaz de mobilizar o aparato de segurança do Estado. Contudo, ao longo desta década, o quadro mudou, a ponto de em "Security: A New Framework for Analysis", de 1998, os autores já tipificarem cinco setores em que a lógica da securitização poderia incidir:

"[...] the military sector is about relationships of forceful coercion; the political sector is about relationships of authority, governing status, and recognition; the economic sector is about relationships of trade, production and finance; the societal sector is about relationships of collective identity; and the environmental sector is about relationships between human activity and the planetary biosphere" (Buzan et al, 1998, p. 7, grifo nosso). 
A adoção do conceito de setores permite a análise de questões específicas de segurança, mas não representa uma fragmentação desta lógica, uma vez que os cinco setores fazem parte de um mesmo contexto social. Trata-se, portanto, de uma tipificação que dá subsídios para um melhor entendimento sobre a pluralidade de significados que podem ser construídos no campo da segurança. Esta divisão é importante por três razões: (1) permite um canal de diálogo significativo com os estudos tradicionais; (2) reflete de forma mais fiel as consequências da utilização da linguagem de segurança em questões não militares; e (3) permite uma nova forma de entender as diferentes qualidades da segurança que são temas de uma agenda mais abrangente (Buzan et al, 1998).

\subsubsection{Relação entre o quadro analítico e os fenômenos sociais}

Em resumo, o trabalho de Buzan e Wæver tem por objetivo apresentar ferramentas de estudo capazes de abranger os fenômenos sociais ligados aos temas de segurança. A proposta do quadro analítico seria, segundo os autores, uma contribuição não normativa ao campo, possibilitando a identificação de padrões de comportamento dos Estados, o que não era mais possível através das perspectivas tradicionais.

Waltz (1979) afirma que para identificar as raízes de determinada política externa, basta o pesquisador investigar os constrangimentos sistêmicos aos quais o Estado é submetido. Compreendida a balança de poder, o analista poderia prever determinado comportamento. O neorealismo, no entanto, não permitia entender o mecanismo pelo qual temas vistos como prosaicos pudessem colonizar a agenda política dos Estados. Ou, na terminologia do próprio neorealismo, Waltz não era capaz de perceber como questões de "low politics" ganhavam a relevância de "high politics" e, por vezes, chegavam a subordinar preocupações militares no centro das decisões estatais.

A contribuição da Escola de Copenhague seria, portanto, o aperfeiçoamento dos quadros analíticos anteriores. Argumenta-se que a ferramenta proposta, ao romper com as bases positivistas, seria mais adequada para entender a lógica da segurança internacional, incorporando o estudo de conjuntos específicos de ações/discursos que ajudam a definir os padrões da interação social. Por isso não haveria uma proposta política normativa - como é 
evidente no caso dos estudos sobre emancipação ${ }^{97}$ (Booth, 1991) - apenas o desenho de um mecanismo teórico mais adequado para abordar o processo de tomada de decisão e, por conseguinte, a relação entre os Estados.

Destarte, ao identificar momentos de securitização e de-securitização, Buzan e Wæver julgam não interferir no processo político de construção de significados. Nas palavras de Tanno (2002): “Quem determinará se existe ou não uma determinada área da vida social que constitui a área de segurança não é o pesquisador, mas sim os atores de cada área" (Tanno, 2002, p. 102). Ou seja, os autores não influenciariam na securitização, teriam apenas o papel de acompanhar o processo pelo qual as diversas questões políticas passam a ser temas de segurança. É uma abordagem que releva o estudo do modus operanti dos agentes, privilegiando a forma como estes apresentam as ameaças.

"Thus, it is the actor, not the analyst, who decides whether something is to be handled as an existential threat. [...] The speech-act approach says only that it is the actor who by securitizing an issue - and the audience by accepting the claim - makes it a security issue. At that level, the analyst cannot and should not replace the actor" (Buzan et al, 1998, p. 35).

No entanto, ao apresentar seu trabalho como meramente elucidativo, sem condições de interferir na prática de governo, Buzan e Wæver contradizem algumas de suas próprias bases teóricas. Criticar a postura normativa é um costume pouco comum aos pesquisadores pós-positivistas, e, dado o caráter hermenêutico da ferramenta analítica proposta, este se torna um ponto vulnerável da Escola de Copenhague. Deste modo, algumas das contradições apontadas no construtivismo de Wendt são evidentes também na obra destes autores. Como avançar uma abordagem que tem como ponto nevrálgico a interpretação coletiva dos fenômenos sociais e defender que a produção dos analistas não tem nenhuma interferência no processo de construção dos significados de ameaça? Além disso, não se pode ignorar a ligação institucional desta Escola com o governo dinamarquês. Certamente, não se trata de uma produção intelectual voltada apenas

\footnotetext{
${ }^{97}$ Para Buzan et al: "The analyst in critical security studies takes on a larger burden than the analyst in our approach; he or she can brush away existing security construction disclosed as arbitrary and point to some other issues that are more important security problems" (Buzan et al, 1998, p. 35).
} 
para o exercício de formulação de políticas - caso corrente entre teóricos neorealistas e os think-tanks norte-americanos -, mas a interposição de interesses políticos e discursos acadêmicos é bastante evidente (Pedersen, 1989; Eriksson, 1993).

\subsubsection{Exceção e De-securitização}

Segundo Wæver e Buzan, o espaço para argumentos normativos na Escola de Copenhague não estaria na explicação de suas ferramentas de análise, mas sim nas implicações do processo de securitização para o comportamento dos governantes. Há uma preocupação no trabalho destes autores - clara em Wæver (1995, 2008 e 2011), mas não em Buzan - de denunciar o uso do espaço de exceção como uma forma de governo.

Assumindo que a lógica do contínuo de segurança implica em perceber os fenômenos como despolitizados, politizados e securitizados, é comum encontrar autores que tratam a securitização como uma forma de politização extrema (ver Rudzit, 2005). Esta perspectiva tem como premissa que o jogo político estatal é extremamente dinâmico e possui mecanismos de controle democrático. Nesse sentido, um determinado ator, após enfrentar a ameaça existencial, retornaria para o espaço político anterior, devolvendo às instituições as prerrogativas legais de governo.

Contudo, as implicações do processo de securitização não são tão claras. Não se trata de uma forma radical de politização, muito pelo contrário ${ }^{98}$. Quando está em curso, a securitização é responsável por aumentar o poder do Estado (e também concentrá-lo), sendo este o ator a lidar com as ameaças, mas não há espaço para escolhas políticas. Decisões de urgência são vistas como necessárias em momentos críticos e estas não podem passar pelo crivo do debate público. Assim, os mecanismos de "checks and balances", centrais no modelo de democracia liberal, são ignorados e a avaliação das ações do governo são deixadas para o futuro.

\footnotetext{
${ }^{98}$ Nesse ponto de suas críticas, os próprios autores da Escola caem em contradição, pois em dado momento afirmam que "Securitization can thus be seen as a more extreme version of politicization" (Buzan et al, 1998, p. 23). Cabe ainda um estudos mais aprofundado sobre esta contradição, mas alguns atores especulam esta seria o resultado das grandes divergências teóricas entre os trabalhos de Buzan e Wæver, que, por vezes, se manifestam neste livro (Williams, 2003).
} 
Portanto, a securitização opera uma ruptura com as normas políticas ${ }^{99}$. Implica na prioridade dada às decisões das lideranças, em detrimento da participação popular. Uma vez em marcha, este mecanismo deixa suas marcas. Ao nomear um fenômeno como problema de segurança, o Estado clama um direito especial de ação. No entanto, Wæver alerta que este direito - o estado de exceção - será sempre parte do jogo, as elites sempre tentarão apresentar seus interesses como questões de segurança nacional: "Power holders can always try to use the instrument of securitization of an issue to gain control over it. By definition something is a security problem when the elites declare it to be so" (Wæver, 1995, p. 54).

Desta forma, o ideal é que haja um processo de de-securitização, no qual os temas sejam debatidos na esfera pública e não decididos por lideranças com poderes emergenciais. Afinal,

“[...] if one has complete security, one does not label it 'security'. It therefore never appears. Consequently, transcending a security problem by politicizing it cannot happen through thematization in security terms, only away from such terms" (Wæver, 1995, p. 56).

No entanto, após elucidar o perigo dos discursos de segurança para a manutenção de normas democráticas, o autor faz a ressalva de que o ato de fazer política é também um ato de escolher opções, logo, de praticar exclusão. Enquanto os pós-estruturalistas tem um projeto de diversificação de atores políticos, garantindo a pluralidade de percepções em meio à sociedade, Wæver afirma que há a necessidade de perguntar para quem se está abrindo o espaço da política: "How can the post-structuralist be sure that 'liberating minds' and ‘transcending limits' will necessarily lead to more peaceful conditions?” (Wæver, 2000, p. 86). O autor acredita que processos de securitização podem levar também a resultados positivos para a sociedade, como foi o caso da formulação do projeto europeu de integração, ou evitar catástrofes, como a ascensão de grupos

\footnotetext{
${ }^{99}$ É importante notar que as críticas ao processo de securitização não se tratam, em momento algum, de um mea culpa dos autores em relação às consequências da expansão da agenda de segurança. Conforme visto anteriormente, o trabalho desta escola é visto por seus formuladores apenas com uma lente mais apurada para enxergar o mundo. Nesse sentido, a ferramenta seria uma forma mais apurada de diagnosticar momentos de securitização, não tendo nenhuma influência na promoção destes processos.
} 
neonazistas (Wæver, 2000). Assim, ao considerar a exclusão como um fenômeno inerente ao processo político, e afirmar que "Politics is inherently about closing off options, about forcing the stream of history in particular directions" (Wæver, 1995, p. 76), Wæver acaba por contradizer seus próprios argumentos normativos.

Indo além, ao privilegiar a análise de discurso dos líderes nacionais e focar nas escolhas destes atores em momentos de crise, a Escola de Copenhague assume um legado bastante controverso em meio à ciência política. Tal postura aproxima sensivelmente estes autores à ampla literatura no campo que aborda o totalitarismo e a importância de decisões emergenciais na condução da política, da qual o principal expoente é Carl Schmitt. A obra de Schmitt vê o espaço da política a partir da capacidade do líder de definir as questões de segurança e designar os inimigos do país. Dito de outra forma, a soberania nada mais é que o poder de invocar o estado de exceção e contornar as normas estabelecidas em caso de ameaça à integridade do Estado ${ }^{100}$ (Schmitt, 2005 [1922]). Desta forma, o autor alemão pressupõe a existência de dois espaços sociais distintos, o da política e o da segurança, nos quais o caráter da relação entre Estado e sociedade seria oposto $^{101}$. No trabalho de Schmitt há uma linha tênue entre a descrição de fenômenos políticos e o privilégio de governos totalitários, com maior capacidade de decisão, em detrimento de democracias ineficientes.

Esta dicotomia (política/segurança), unida na imagem do soberano, é central para a Escola de Copenhague. A ferramenta da securitização opera justamente na análise das rupturas com a normalidade e a imersão no campo da segurança. $\mathrm{O}$ foco na descontinuidade dos processos democráticos é o legado de Schmitt na percepção de Wæver e Buzan acerca da política e, como será visto ao longo da dissertação, é também o motivo de grande parte das críticas a esta Escola $^{102}$.

\footnotetext{
${ }^{100}$ Esta é a questão central do livro "Political Theology: Four Chapters on the Concept of Sovereignty", originalmente publicado em 1922. Schmitt abre este livro afirmando que "Sovereign is He who decides on exception" (Schmitt, 2005 [1922], p. 5).

${ }^{101}$ Não havendo iminência de guerras, a sociedade poderia controlar as ações de seus governantes, mas em momentos de crise, o Estado precisaria (e deveria) rogar para si poderes especiais para defender a nação. Este foco na decisão de um ator político específico e a importância denotada às brechas para o poder totalitário - somado à própria trajetória acadêmica e política de Schmitt - fez com este autor ficasse conhecido como um dos teóricos do fascismo.

${ }^{102}$ Ver Huysmans, 1998b, 2006b e 2008; Bigo, 2002; Browning \& Mcdonald, 2011.
} 


\subsubsection{Ampliação da agenda de segurança: o estado da arte dos estudos de securitização}

Ao longo dos últimos vinte anos, a teoria de securitização se tornou muito popular entre os acadêmicos da disciplina de Relações Internacionais, especialmente na Europa. Apesar de o Instituto de Pesquisa para a Paz de Copenhague ter encerrado seus trabalhos em janeiro 2003, parte dos pesquisadores se manteve ativa no Instituto Dinamarquês de Estudos Internacionais $^{103}$ (DIIS), produzindo conhecimento e ajudando a disseminar o arcabouço proposto por Wæver e Buzan.

Desenvolvendo uma pesquisa quantitativa nos arquivos da ISA, Gad e Petersen (2011) confirmam o crescimento desta Escola (gráfico 3). Em 2002, apenas um trabalho foi apresentado debatendo processos de securitização. Poucos anos depois, este número subira para 52 (entre artigos e papers). Esta pesquisa não diz muito sobre a forma com o conceito foi utilizado, mas reflete sua popularidade e relevância teórica, principalmente nos anos 2000 (Gad e Petersen, 2011).

Gráfico 3: Artigos e papers sobre securitização apresentados na ISA

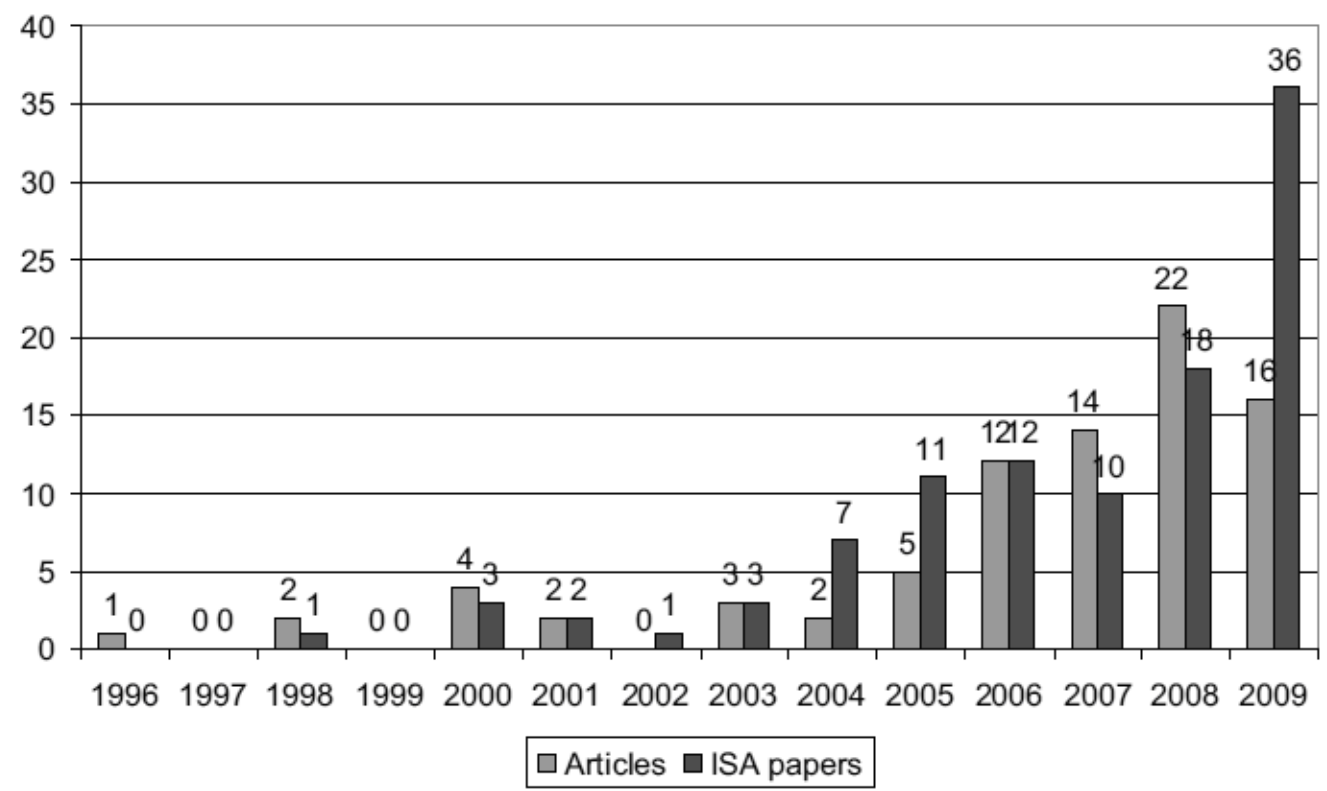

(Gad e Petersen, 2011, p. 316)

103 O DIIS é um instituto de pesquisa financiado, principalmente, pelo governo dinamarquês. Para mais informações sobre esta instituições, ver: WWW.diis.dk/sw96516.asp 
Nesse sentido, é possível afirmar que mesmo tendo buscado apenas desenvolver uma ferramenta para entender processos de tomada de decisão (Buzan et al, 1998), a Escola de Copenhague ajudou a disseminar o debate sobre a ampliação da agenda de segurança, cujas consequências políticas são notórias. Analisando as bases de dados de algumas revistas europeias de segurança, o mesmo padrão da ISA se repete. Na Security Dialogue, por exemplo, além da vasta bibliografia metateórica, foram publicados artigos debatendo o uso da securitização em temas como: tráfico de pessoas (Jackson, 2006), crise financeira (Kessler, 2011), doenças epidemiológicas (Sjöstedt, 2008), direitos de minorias (Jutila, 2006), energia (Ciută, 2010) e religião (Bilgin, 2008). No entanto, os tópicos que receberam mais atenção dos pesquisadores foram a identidade europeia e o fenômeno da imigração ${ }^{104}$ (Hoogensen \& Rottem, 2004; Erickson, 2007; Hansen, 2011; Lawson, 2011). Aparentemente, o campo ignorou uma das primeiras recomendações de Wæver, Buzan e de Wilde: "There are intellectual and political dangers in tacking the word security onto an ever wider range of issues" (Buzan et al, 1998, p. 1).

Houve, como receavam estes autores, uma transferência dos conceitos utilizados nos estudos de segurança para outras áreas das RIs, fruto, em grande medida, de duas tendências: (1) a expansão da agenda de segurança dos Estados e (2) a própria ampliação do campo de estudos, que passa a enquadrar fenômenos tão distintos quanto a política do Burundi para o controle da AIDS (Seckinelgin et al, 2010) e a crise entre Noruega e Rússia acerca da pesca ilegal (Åtland \& Bruusgaard, 2009) em uma mesma perspectiva. Estes dois movimentos são simultâneos e intimamente relacionados, já que, por um lado, as novas preocupações de segurança dos Estados levam a novas fronteiras de estudos

\footnotetext{
104 A Intenational Migration, publicação que há mais de cinco décadas contribui para a disseminação de artigos sobre movimentos migratórios, publicou nos últimos dez anos artigos de doze autores que abordam este fenômeno a partir da lógica da securitização. Breves pesquisas em outras revistas acadêmicas do campo revelam um padrão semelhante. A Cooperation and Conflict publicou nos últimos quinze anos 43 artigos debatendo a lógica da securitização ou aplicando-a em estudos empíricos. Já a Security Studies, desde 2008, já apresentou 10 artigos que dialogam com este conceito, enquanto a Review of International Studies publicou 18 artigos desde 1997. Uma das revistas mais relevantes no campo de Estudos Europeus também apresenta trabalhos que debatem com os argumentos da Escola de Copenhague: o Journal of Common Market Studies publicou, entre 2004 e março de 2012, 49 artigos. Mesmo o British Journal of Politics and International Relations que não é especializado em estudos de segurança, publicou ao menos um artigo por ano com foco neste conceito desde 2007. Estes levantamentos foram feitos até setembro de 2012.
} 
acadêmicos e, por outro, estes estudos contribuem para uma compreensão dos fenômenos sociais cada vez mais sob as lentes da segurança.

Os padrões desta convergência ficarão mais claros no quarto capítulo, quando for analisada de forma abrangente a articulação entre os debates sobre segurança e imigração na Europa. No momento, cabe entender como este processo pode levar a conclusões nem sempre apuradas. A proposta de aprofundar a pesquisa sobre a criação da Frontex vai justamente nesse sentido, demonstrando que a lógica da securitização leva a análises focadas em poucas fontes - discursos de líderes políticos e recepção por parte da audiência - e em momentos históricos específicos, o que a torna incapaz de entender o processo de criação desta agência. Ou melhor, as leituras a partir de Wæver e Buzan, por terem ferramentas analíticas impróprias, observam a sociedade sempre em busca de "ineditismos", de fenômenos que marquem rupturas históricas, quando muitas vezes - e é o caso da política de controle de fronteiras da União Europeia - trata-se de um longo processo político.

\subsection{Consequências da securitização da imigração na Europa}

Desde o fim da Segunda Guerra Mundial, a imigração tem sido um tema importante para os policy-makers europeus. Após o conflito, os países precisaram cooperar para a identificação e transporte de um enorme contingente populacional que havia sido forçado a se deslocar nos anos anteriores. A recuperação da economia do continente também envolveu a imigração, uma vez que os governos encorajaram o fluxo de estrangeiros, principalmente dos demais países europeus e de suas colônias, para trabalharem no soerguimento das indústrias nacionais. Até a década de 1970, milhões de famílias foram convidadas a ingressar na Europa, ajudando a torná-la novamente uma região rica. Ao longo deste período, no qual foi construído o oneroso modelo de Estado do bem-estar social, os estrangeiros foram vistos como subsídios importantes para o crescimento ${ }^{105}$ e, apesar de os

\footnotetext{
${ }^{105}$ Contudo, desde então alguns políticos europeus já estavam preocupados com o impacto social do fluxo de imigrantes. Apesar de terem um papel importante na economia, a Comunidade Econômica Europeia aprovou, em 1968, a regulação 1612/68 sobre liberdade de movimento para trabalhadores dentro da comunidade. Este regulação discriminava os imigrantes, afirmando que a referida liberdade se aplicava apenas aos nacionais dos Estados membros.
} 
casos de xenofobia terem aumentado ${ }^{106}$, as políticas direcionadas a este grupo de indivíduos eram, de uma forma geral, voltadas para sua inserção em meio à sociedade.

Este retrato da imigração na Europa é bastante diferente do atual. Em junho de 2012, durante campanha para a formação do governo grego, Antonis Samaras declarou que "Greece today has become a center for illegal immigrants. We must take back our cities" (Samaras apud Rettman, 2012). Indo além, o futuro primeiro ministro ainda caracterizou os imigrantes como uma doença para o país, afirmando que a cura necessária era a adoção de medidas que restringissem a entrada de estrangeiros. O discurso de Samaras é repetido e endossado por muitos governantes europeus ${ }^{107}$, o que evidencia uma mudança significativa nas percepções acerca do impacto deste fenômeno demográfico.

Apesar da relevância do tema, não há um consenso em meio aos pesquisadores sobre a forma pela qual se deu esta transformação. Há autores que privilegiam o fraco desempenho econômico das últimas décadas como propulsor do sentimento negativo em relação aos estrangeiros (Papademetriou, 1996; Schierup et al, 2006), outros vão além e se debruçam sobre o impacto da diversidade cultural na reconstrução (ou desconstrução) da identidade nacional (Schiffauer, 1997; Melotti, 1997; Geddes, 2003). Sem ignorar as contribuições desta literatura, há ainda um terceiro grupo - objeto desta dissertação - que aborda a influência das questões de segurança na percepção do imigrante como ameaça.

Nesse sentido, compreender as distintas narrativas históricas é um bom início para o estudo das políticas europeias para imigração. Através da incorporação destas narrativas, pode-se perceber que a entrada de estrangeiros não foi sempre vista como um problema econômico, menos ainda como um desafio à segurança, mas, ao contrário, foi, durante muitos anos, concebida como a solução

\footnotetext{
${ }^{106}$ Para uma análise sobre políticas de combate à violência contra o imigrante neste período, ver Papademetriou, 1996.

${ }^{107}$ Discursos semelhantes não são raros em meio à elite política grega. Recentemente, dada a pressão da UE para que a Grécia controlasse de forma mais eficiente suas fronteiras e as dificuldades para tal provenientes do maior número de refugiados da crise na Síria, Nikos Dendias, ministro da ordem pública, defendeu a prática da deportação. Dendias afirmou que esta atitude "is the best thing that could happen to them [imigrantes], as they are living in miserable conditions in Athens" (Dendias apud EurActiv, 2012c). Além disso, o ministro caracterizou os fluxos de imigrantes como uma invasão e afirmou que eles representam "a bomb at the foundation of the society and the state" (Dendias apud EurActiv, 2012c).
} 
para as dificuldades internas do continente. A criação da Frontex é uma consequência direta desta mudança na percepção acerca do imigrante, que deixa de ser visto como propulsor do desenvolvimento local e passa a ser um ator social cuja imagem é construída a partir da lógica da ameaça (Léonard, 2011). Visto isso, cabe entender como a Escola de Copenhague percebe a construção desta ameaça.

\subsubsection{As leituras da Escola de Copenhague para a criação da Frontex}

As cenas da colisão dos aviões contra o World Trade Center e o Pentágono rodaram o mundo. As imagens de pessoas correndo com medo, ruas empoeiradas e, principalmente, das duas torres ruindo em meio ao fogo e à perplexidade de jornalistas, bombeiros e policiais chocaram e entristeceram bilhões de pessoas. Os eventos de 11 de setembro de 2001, no entanto, só ganharam o significado coletivo atual alguns dias depois dos fatos terem ocorrido, quando George Bush veio a público afirmar que os Estados Unidos enfrentavam, pela primeira vez desde a última guerra mundial, um ataque contra seu território (Bigo, 2010b). A ameaça agora não eram os japoneses, mas sim os grupos terroristas e países que os apoiavam. Estes representavam um perigo para o modo de vida dos EUA, para sua liberdade e democracia. O terrorismo, segundo Bush, ia contra valores fundamentais da humanidade e, portanto, esta deveria estar unida na "Guerra ao Terror".

A literatura sobre processos de securitização tem como objeto justamente a construção intersubjetiva de fenômenos políticos. Assim, o foco das análises não recai no evento em si, mas na forma como este é apresentado para a sociedade. Nesse sentido, o discurso de Bush no dia 14 de setembro de $2001^{108}$, no qual os atentados foram descritos como ataques e alguns países passaram a formar o "eixo do mal", configura-se como um ato de fala. A partir deste dia, os terroristas se tornaram o principal inimigo, o que exigiu como resposta o engajamento na Guerra ao Terror (Zucconi, 2004).

\footnotetext{
${ }^{108}$ Discurso do presidente George W. Bush no dia 14 de setembro de 2001. Disponível em: http://www.presidency.ucsb.edu/ws/index.php?pid=63645. Acesso em 12 de julho de 2012. Para mais sobre a construção intersubjetiva do significado dos atentados a partir do discurso no dia 14 de setembro, ver Bigo (2010b).
} 
Diversos líderes europeus seguiram o exemplo de Bush e deram respaldo às novas políticas de segurança. Para os teóricos da securitização, este momento é crucial para entender o recrudescimento do controle de fronteiras na Europa e, consequentemente, a criação da Frontex. O ponto comum entre autores da Escola de Copenhague é a análise dos discursos destes líderes sobre os atentados de setembro de 2001 e sua capacidade de convencer a opinião pública sobre a urgência de combater o terrorismo (Kicinger, 2004; Callovi, 2004; Levy, 2005; Bilgic, 2006; Lugna, 2006). Através do método descrito, aponta-se a construção dos atentados como um ataque também aos valores europeus. Assim, esta retórica teria servido para implementar políticas mais restritivas, a partir das quais os países (ou a UE) estariam mais aptos a lidar com os desafios de segurança.

O fato de os membros da al-Qaeda terem origem árabe e uma história de vida no continente europeu foi lembrado por diversos políticos ao fazerem analogias entre os imigrantes e os terroristas ${ }^{109}$ (Conselho Europeu, 2003; Karyotis, 2007; Bourbeau, 2011). Deste modo, argumenta-se que ao construir o terrorismo como uma ameaça existencial os líderes europeus estariam fazendo o mesmo com a imigração, o que justificaria medidas de exceção também neste campo. Na prática, este processo se materializou nas políticas direcionadas ao controle do fluxo de pessoas, sendo este praticado por meio de restrições ao acesso, detenção e deportação de estrangeiros (Zucconi, 2004).

Lahav et al (2007) assumem que mesmo antes de a rede al-Qaeda ganhar manchetes de jornais pelo mundo, já havia iniciativas na Europa em prol da redução do número de imigrantes, principalmente árabes. Não obstante, os autores afirmam que este quadro foi radicalizado após 2001:"[...] the political aftershocks following the events of September 11, 2001 in the United States, the Madrid bombings of 2004, and the 2005 London terrorist attacks have accelerated the securitization of immigration" (Lahav et al, 2007, p. 3).

Comparando os resultados de pesquisas de opinião com membros do Parlamento Europeu e analisando o discurso de alguns deputados, Lahav et al demonstram que, entre 1993 e 2004, a percepção sobre o impacto da imigração

\footnotetext{
${ }^{109}$ Na proposta para a Estratégia de Segurança Europeia, Javier Solana apresenta à Comissão, ao Parlamento e ao Conselho as principais ameaças ao território europeu, colocando em primeiro lugar o terrorismo. Para o autor, uma das causas para este fenômeno seria a imigração. Nas palavras de Solana, "The most recent wave of terrorism is global in its scope and is linked to violent religious extremism. It arises out of complex causes [entre elas] the alienation of young people living in foreign societies" (Conselho Europeu, 2003, p.2).
} 
em questões de segurança aumentou sensivelmente, sendo possível encontrar o momento de inflexão. Ao longo da década de 1990, os temas mais relacionados pelos deputados aos imigrantes eram economia e identidade. Até então a retórica crítica se limitava a apontar os perigos para a tradição cultural ocidental e para a identidade comum que os europeus começavam a criar. Somente após os atentados nos EUA, o tema do terrorismo passou a ser visto como o principal aspecto da imigração. Segundo os autores, esta mudança foi fundamental para que a UE aprovasse, na primeira metade dos anos 2000, políticas integradas de controle de fronteira. Deste modo, Lahav et al argumentam que a securitização da imigração na Europa se baseou em um triângulo de objetos referentes. Enquanto este fenômeno era visto como um problema apenas para a identidade e economia europeias, apesar dos diversos discursos de retravam os imigrantes como ameaças, o processo de securitização não se concretizava. Com o terceiro vértice do triângulo, o terrorismo, alguns líderes europeus teriam obtido sucesso na caracterização deste fenômeno como uma ameaça existencial.

Valendo-se também da ferramenta teórica da Escola de Copenhague, Norman (2006) faz uso dos documentos oficiais e relatórios da UE para tentar comprovar seu argumento acerca da securitização das fronteiras europeias. $\mathrm{O}$ autor identifica os ataques em Nova York, Madri e Londres como responsáveis por uma clara transformação no padrão pelo qual os líderes europeus se referem à imigração.

Após os atentados terroristas nos Estados Unidos, o Conselho de Justiça e Assuntos Internos convocou uma reunião extraordinária, realizada no dia 20 de setembro, na qual foi decidido que "[...] the seriousness of recent events has led the Union to speed up the process of creating an area of freedom, security and justice and to step up cooperation with its partners, especially the United States $^{110 ", ~(C o n s e l h o ~ d e ~ J u s t i c ̧ a ~ e ~ A s s u n t o s ~ I n t e r n o s, ~ 2001) . ~ I n d o ~ a l e ́ m, ~ o ~ a u t o r ~}$ argumenta que nesta reunião foi traçada a estratégia de combate ao terrorismo que viria a ser aprovada em dezembro do mesmo ano, no Conselho de Laeken. Esta estratégia consistia no gerenciamento integrado de fronteiras (conceito que fundamenta as ações da Frontex), no qual as agências europeias teriam papel fundamental.

\footnotetext{
${ }^{110}$ Apesar de o autor usar este documento para provar seu ponto sobre a securitização, é relevante o fato de não haver nenhuma menção direta à imigração.
} 
Norman investiga ainda as justificativas dos líderes europeus para que algumas das instituições da UE tivessem seu escopo de ação expandido. Antes restrito pelo intergovernamentalismo, "Overnight the domain of EU counterterrorist cooperation became one of the most high profile areas of cooperation between EU Member States [...] (Norman, 2006, p. 227). Esse cenário político contribuiu para que as agências de segurança interna da UE ultrapassassem a barreira do terceiro pilar e ganhassem prerrogativas legais para atuar também com assuntos comunitários. Este foi o caso da Europol, da Eurojust e dos debates sobre a criação da Frontex. Segundo o autor,

"The terrorist acts must be regarded as the first truly 'cross pillar' test of the Union's role as a security actor [...]. Therefore, September 11th provided an opportunity to the EU for radical action to implement strategic objectives in the field of criminal police and judicial cooperation, in the name of counterterrorism [...]" (Norman, 2006, p. 220).

Ao afirmar que os atentados terroristas representaram um momento fundamental de expansão da cooperação policial e das políticas europeias para o controle de fronteiras, Norman pode ser colocado ao lado de Lehav et al. Segundo estes autores, foi a partir deste evento que os líderes europeus passaram a construir de forma sistemática a imigração como uma ameaça e obtiveram sucesso na aprovação de medidas emergenciais para evitar atos terroristas no continente.

Aprofundando esta análise, Karyotis (2007) destaca a formulação do documento de trabalho "The relationship between safeguarding internal security and complying with international protection obligations and instruments", apresentado no dia 05 de dezembro de 2001 pela Comissão Europeia, como um marco para a securitização da imigração na Europa. Neste, segundo a autora, imigrantes e refugiados são retratados como terroristas em potencial, o que justificaria a adoção de medidas mais restritivas no controle de fronteiras e evitaria a ocorrência de "avenues for those supporting or committing terrorist acts to secure access to the territory of the Member States of the European Union (Comissão Europeia, 2001, p. 6). Karyotis (2007) ressalta ainda que este mesmo documento enumera práticas necessárias para a contenção da ameaça terroristas. Segundo o documento: 
“[...] pre-entry screening, including strict visa policy and the possible use of biometric data, as well as measures to enhance co-operation between border guards, intelligence services, immigration and asylum authorities of the State concerned, could offer real possibilities for identifying those suspect of terrorist involvement at an early stage" (Comissão Europeia, 2001, p. 6).

Para a autora, estas medidas são muito próximas às atividades que a Frontex passaria a exercer a partir de 2005, o que indica a influência do processo de securitização decorrente da resposta aos atos de 11 de setembro de 2001 na criação desta agência. Ferreira (2011) exemplifica este argumento afirmando que,

“[...] as práticas comunitárias operacionalizaram um intenso processo de securitização da liberdade de locomoção, tanto do ponto de vista interno quanto externo [...] e desenvolveu-se um pesado aparato de segurança, composto pela proliferação de agências de inteligência e segurança comunitárias (Ferreira, 2011, p. 50).

Trazendo mais elementos a este ponto de vista, van Krieken (2005) afirma que:

"[...] it comes as no surprise that, in the wake of the 2001 events, border control and the increased screening of migrants and would-be migrants became an issue of the utmost urgency in many countries. [...] Within this realm, efforts toward a so-called multicultural society were considered to be in need of rethinking" (van Krieken, 2005, p. 53).

Este autor desenvolve um estudo comparativo entre as políticas europeias para a imigração antes e depois de 2001 e conclui que há uma mudança de paradigma na forma pela qual a UE lida com o desafio da imigração ilegal. De acordo com a análise de van Krieken, as motivações por trás das práticas de controle das fronteiras comuns se transformam por completo. Durante os anos 1990, quando a cooperação nesta área teve início, esperava-se que o controle impedisse o crime organizado transfronteiriço e a deterioração econômica da periferia das grandes cidades. Após os atentados terroristas, o que era uma questão de segurança interna, passou a ser encarado como um desafio urgente para a 
segurança internacional. Ao construir a imagem da imigração segundo esta lógica, os líderes europeus foram capazes de trabalhar com este fenômeno a partir de novas premissas, abrindo espaço para políticas de exceção.

Indo além, o autor afirma que a criação das agências europeias focadas em policiamento e coleta de dados só foi possível dada a percepção geral de que a Europa está se tornando "[...] a new battleground not just for the war on terrorism, but also for common policies and interaction." (van Krieken, 2005, p. 65). Desta forma, van Krieken argumenta que a securitização estaria completa, uma vez que a conexão entre imigração e terrorismo teria sido aceita pela opinião pública europeia e a demanda por medidas excepcionais teria levado à reconsideração das políticas até então adotadas. Assim, para o autor, a questão do imigrante/terrorista se tornou uma prioridade na agenda da UE, culminando com a formulação de novos mecanismos de controle do fluxo de estrangeiros. A Frontex, como a principal instituição para coordenação das fronteiras externas, estaria imersa neste processo.

A influência de agentes de segurança dos Estados Unidos é abordada nesta literatura como um fator fundamental para a securitização da imigração na Europa $^{111}$ (Occhipinti, 2003, Den Boer, 2003; Levy, 2005; Schain, 2007; Armitage Jr., 2007; Riekmann, 2008; Ferreira, 2011; Archick, 2012). Estudando as recomendações da Comissão Europeia para combater o terrorismo, Levy (2005) reconhece alguns dos instrumentos implementados pelo governo americano nos dias que se seguiram aos atentados. Segundo o autor, a convergência entre as políticas adotadas dos dois lados do Atlântico seria resultado do crescente diálogo entre Bush e seus pares europeus. Levy argumenta que os discursos sobre a "Guerra ao Terror" teriam sido exportados, o que resultou no processo de securitização também na Europa. Para Den Boer (2003), o resultado mais significativo desta aproximação, além de um alinhamento geopolítico, seria justamente a reprodução na Europa de medidas anti-terroristas. Para a autora:

\footnotetext{
${ }^{111}$ Para uma ampla análise sobre as inovações técnicas implementadas nas políticas europeias de vigilância e controle de fronteiras advindas da cooperação com agentes de segurança dos EUA, ver Archick, 2012. Este autor aborda o desenvolvimento de novos mecanismos de segurança biométrica, acordos para padronização e compartilhamento de informações sobre indivíduos suspeitos, adoção de modelos de vistos e passaportes mais seguros e outros.
} 
"It is clear that the transatlantic axis against terrorism has opened the EU-door to the USA far more widely than before, and that there is a spill-over from terrorism to other security or mobility-related issues. Border controls, criminal justice co-operation, immigration and asylum policy have thus become elements inserted in a wider transatlantic security policy continuum" (Den Boer, 2003, p. 16).

Assim, mesmo não abordando os discursos sobre "Guerra ao Terror", Den Boer também conclui que teria ocorrido a securitização, sendo o principal reflexo deste processo a adoção de legislação de cooperação consular, políticas de vistos e controles de identidade que "reveal that anti-terrorism efforts have also extended to immigration and border controls, which may be read as a consequence of the 'securitisation' of the migration discourse" (Den Boer, 2003, p. 11).

Esta relação teria ficado ainda mais clara após os atentados em Madri e Londres, quando os países europeus decidiram pôr em prática o EU Action Plan on combating terrorism, de 2006. Este plano de ação prevê uma ligação institucional entre a Europol e órgãos do governo americano, o que facilitaria a coordenação de atividades e a troca de informações vitais para a prevenção contra novos ataques. No mesmo ato, o Conselho aprovou também a criação de uma equipe específica no marco da Europol para lidar com a ameaça terrorista (Riekmann, 2008).

Conforme Riekmann (2008) argumenta, após o fortalecimento da Europol, o passo seguinte da UE foi importar os mecanismos de controle de fronteiras adotados pelos Estados Unidos. Para viabilizar esse processo, seria necessário criar uma agência voltada especificamente para este fim. Abria-se, portanto, espaço para a Frontex. Segundo a autora,

"The incidents of 9/11 pushed respective developments a step further and led to a 'securitization' of migration policies, by linking them to the issue of international terrorism. As a consequence, the Council and the Commission have been given a mandate to work out 'arrangements for cooperation between services responsible for external border control and to examine the conditions in which a mechanism or common services to control external borders could be created", (Riekmann, 2008, p. 29). 
Desta forma, enquanto os Estados Unidos criaram um Departamento para Segurança Interna e adotaram medidas emergenciais para a identificação de indivíduos suspeitos, alguns países europeus e a UE deram maior respaldo jurídico para a atuação dos órgãos de segurança e patrocinaram a criação de uma agência específica para a cooperação no controle das fronteiras.

É válido ressaltar que os autores trabalham com as ferramentas analíticas da Escola de Copenhague, mas a maioria critica o processo de securitização da imigração. Há um diagnóstico de que a Frontex seria fruto da construção da imagem do imigrante como uma ameaça, mas também que as consequências deste ato político são graves, levando, em muitos casos, ao desrespeito à Carta de Direitos Fundamentais da própria União Europeia. Galli (2008) reflete bem este sentimento, acusando o uso indiscriminado da retórica da emergência como justificativa para a repressão. Nas palavras da autora,

"After the bombings in Madrid and London, which revealed the vulnerability of the European countries and brought the threat of terrorism closer to everyday European life, governments have increasingly stressed the need for emergency powers to counter the threat posed by religious radicals, even if this compromises civil liberties" (Galli, 2008, p. 7).

Em resumo, este grupo de autores trabalha com a abordagem de securitização baseados em dois argumentos principais: (1) que a relação entre imigração e terrorismo é um fenômeno extraordinariamente novo, demandando a reformulação das políticas de segurança das instituições europeias; e (2) que os eventos de 11 de setembro de 2001 revelaram a urgência (real ou imaginária) de se encarar a imigração como um vetor do terrorismo, o que leva os governos europeus a tomarem medidas excepcionais. A conclusão lógica desta abordagem é que o projeto da Frontex foi uma das respostas oferecidas pela UE para lidar com o novo contexto da "Guerra ao Terror", na qual o imigrante se torna uma ameaça e, portanto, o aparato estatal regular torna-se insuficiente para garantir a proteção da população.

Por fim, conforme colocado no início desta seção, cabe analisar outras narrativas acerca do processo de criação da Frontex. Ao incorporar uma perspectiva histórica sobre as práticas de controle de fronteiras da UE, é possível 
ressaltar outros aspectos do processo de formulação da política europeia e, fundamentalmente, questionar as leituras que partem da Escola de Copenhague para explicar o surgimento desta agência. 


\section{3.}

\section{Discurso e prática: Os vazios da Escola de Copenhague e alternativas teóricas à securitização}

A vasta literatura que analisa a criação da Frontex a partir do arcabouço teórico da Escola de Copenhague está bastante arraigada em meio ao campo de estudos de segurança. No entanto, esta dissertação traz uma leitura alternativa para o desenvolvimento das políticas de controle de fronteiras da UE, afastando-se da lógica da securitização e avançando uma abordagem que busca raízes mais profundas para a percepção acerca da imigração como uma ameaça à Europa. Desta forma, será rejeitada a hipótese de que os atentados de 11 de setembro de 2001 propiciaram um processo de securitização da imigração e buscar-se-à demonstrar que, por mais que estes eventos tenham influenciado os discursos de líderes europeus, as políticas implementadas na última década seguiram as estratégias recomendadas de forma sistemática por agentes de segurança (profissionais, guardas, burocratas e técnicos) ao menos desde a assinatura do Acordo de Schengen, em 1985. Para tanto, ao invés focar em momentos de radical inflexão política, quando medidas de emergência teriam sido aprovadas, será priorizado o estudo do longo processo de convergência entre as agendas e práticas dos campos da imigração e de segurança.

Ambas as leituras apontam para a difícil condição do imigrante frente à repressão do aparato de segurança da UE e das forças nacionais, mas é importante ressaltar que esta já existia antes dos atentados nos Estados Unidos, e as premissas das políticas europeias foram pouco alteradas desde então. Nesse sentido, este capítulo buscará traçar as falhas da ferramenta de securitização no que tange à análise do recrudescimento das práticas de controle de fronteiras, demonstrando que a teoria formulada por Wæver e Buzan, ao olhar apenas para momentos de descontinuidade política, é incapaz de compreender o processo pelo qual a agenda de segurança passou a dominar os debates sobre imigração e asilo na Europa. Para tanto, será avançada uma leitura distinta acerca deste processo, pautada, principalmente, no trabalho de Pierre Bourdieu, que traz um olhar sociológico para os estudos de segurança. Por fim, esta abordagem será privilegiada na análise sobre a criação da Frontex. 


\subsection{Os vazios da teoria da securitização}

Desde sua formulação, o quadro da securitização tem recebido dois tipos de críticas: as que são direcionadas à clareza com a qual alguns de seus elementos foram desenvolvidos e definidos por Wæver e Buzan, e aquelas que contestam suas premissas teóricas, seja por sua forma ou impacto político. O primeiro grupo, bastante numeroso na academia, dialoga diretamente com os autores citados e está engajado no projeto de aperfeiçoar alguns dos pontos da teoria da securitização, tornando-a uma ferramenta cada vez mais apurada. Sob esta lógica, foram produzidas pesquisas que: lidavam com a possibilidade de aplicação desta teoria em países com sistemas de governo distintos do europeu (Wilkinson, 2007), buscavam uma melhor definição de quem seriam os atores securitizantes e como estes podem variar (Balzacq, 2005; Vaughn, 2009), reconheciam algumas falhas em Buzan e Wæver no que tange a audiência, a maneira pela qual esta é representada e como interage com o discurso dos líderes (Léonard \& Kaunert, 2011) e buscavam aprofundar o conceito de atos de fala, deixando clara a influência de Ludwig Wittgenstein, Jacques Derrida, John Austin e Jürgen Habermas (Wæver, 2004; Taureck, 2006). Este grupo reconhece no modelo da Escola de Copenhague uma forma válida para enxergar o processo de construção coletiva dos fenômenos sociais e, portanto, limita suas críticas a aspectos específicos da ferramenta de securitização.

Por mais que levantem questões substantivas a respeito da Escola de Copenhague, os trabalhos mencionados permanecem atrelados às bases teóricas propostas por Wæver e Buzan, o que os impede de enxergar algumas falhas centrais nesta abordagem e, principalmente, as implicações éticas e políticas das perspectivas avançadas. Nesse sentido, esta dissertação está voltada para o segundo grupo de autores, que evidencia as preocupações normativas no fazer teórico e busca analisar os fenômenos a partir das práticas rotineiras das burocracias estatais. Isto é feito abordando o impacto de atores ignorados pela Escola de Copenhague na construção de conhecimento e denunciando as consequências da utilização de argumentos "técnicos" sem que haja questionamento de suas bases políticas. 


\subsubsection{Limitações da ferramenta analítica da Escola de Copenhague}

Conforme visto no primeiro capítulo, as inovações propostas por Wæver (1995) para os estudos de segurança foram responsáveis por um intenso debate metateórico, que ajudou a ampliar as agendas de pesquisa do campo. A incorporação do componente intersubjetivo, afirmando que as percepções sobre o perigo não são objetivas, mas sim fruto de uma experiência social na qual fenômenos antes não-problematizados passam a ser vistos como ameaças existenciais a determinados objetos referenciais, levou a Escola de Copenhague a romper com as leituras positivistas e ajudou a sedimentar o espaço para abordagens críticas.

Ao problematizar o conceito de segurança, negando seu caráter natural, a Escola de Copenhague identificou diferentes contextos nos quais este poderia operar, bastando que se seguisse um processo em três etapas: (1) identificação e nomeação de um problema de segurança, (2) aceitação por parte da audiência de que se trata de um perigo iminente e (3) autorização para que o Estado aja em um regime de exceção na eliminação da fonte do perigo (Buzan et al, 1998). Deste modo, enquanto as agendas de pesquisa neorealista e liberal estavam voltadas para as percepções e cálculos racionais dos atores sobre os constrangimentos internacionais, Wæver não se interessou pelas reais intenções dos atores, mas sim pela forma como estes constroem socialmente significados de segurança. $\mathrm{O}$ foco, portanto, recai nos atos de fala, na ideia de que ao empregar determinadas palavras para descrever um fenômeno, os líderes estão atuando em sua definição.

Outro aspecto da Escola de Copenhague que também teve forte impacto sobre o campo foi a adoção de um projeto de pesquisa que privilegia o estudo de momentos de descontinuidade. Esta escola identifica os possíveis contextos nos quais os fenômenos sociais são percebidos, podendo ser estes (1) ignorados pela agenda política, (2) motivo de debates públicos ou (3) securitizados. A ferramenta desenvolvida por Wæver e Buzan é adequada justamente para a análise de mudanças nas regras do jogo político doméstico, quando, pela urgência da ameaça, líderes recebem a anuência da sociedade para exercer sua autoridade com menos controle democrático.

Em resumo, as pesquisas que se pautam neste modelo analítico devem observar as três etapas mencionadas, priorizando os discursos proferidos pelos 
atores políticos capazes de mobilizar a sociedade e a forma como estes moldam os entendimentos coletivos a respeito de determinado fenômeno em um momento específico. Assim sendo, esta literatura acaba por privilegiar situações de crise em que supostamente ocorreu um processo de securitização, sem que haja uma preocupação em observar o desenvolvimento de debates por um longo período.

As críticas à capacidade analítica da Escola de Copenhague giram em torno desses dois pontos. Por um lado, busca-se demonstrar ser possível a construção de significados de segurança que não passem somente pelos discursos de líderes políticos e, por outro, revela-se a importância de produzir estudos que não tenham um enfoque temporal restrito a cenários de crise, mas que considerem os diversos elementos que compõe a construção de significados a respeito de um fenômeno social (Balzacq, 2008).

Aplicando a lógica da securitização no nível das instituições europeias, Neal (2009) evidencia muitas de suas limitações. Segundo Neal, não há como apontar os atores políticos centrais para a construção de significados de segurança na UE. Enquanto no nível doméstico os ministros e chefes de estado tem grande influência na opinião pública e espaço nos meios de comunicação, o mesmo não ocorre no nível europeu. A reprodução dos discursos dos principais membros da Comissão Europeia e demais instituições é extremamente reduzido, reverberando apenas em meio à elite política e ambientes acadêmicos. Para o autor, este padrão fica ainda mais claro em momentos de crise, quando a União perde espaço para debates no contexto interno. Ou seja, exatamente nas situações em que a ferramenta da Escola de Copenhague recomenda análises de discurso dos líderes europeus, a repercussão dos políticos nacionais é consideravelmente superior.

Em pesquisa publicada em janeiro de 2012, o Eurobarômetro confirma os argumentos de Neal, apontando para a falta de conhecimento em meio à população acerca de muitos dos membros da Comissão Europeia, mesmo quando se trata de um representante do próprio país. Catherine Ashton, vice-presidente da Comissão Europeia e chefe do Serviço Europeu de Ação Externa, tem seu trabalho praticamente ignorado por $84 \%$ dos cidadãos ingleses ${ }^{112}$. Nos demais

\footnotetext{
${ }^{112}$ De acordo com a pesquisa, apenas $16 \%$ dos ingleses leram a respeito ou ouviram falar sobre as ações da baronesa Ashton na imprensa local. Esta mesma pesquisa buscou a relevância dos acessos aos websites pessoais dos principais membros da CE. Em dezembro de 2011, no mês em que a UE aprovou sanções contra o Irã e a Síria, o site da baronesa foi apenas o $16^{\circ}$ (entre 27) mais visitado.
} 
países da UE o mesmo ocorre com Herman Von Rompuy, presidente do Conselho Europeu, e José Manuel Durão Barroso, presidente da Comissão Europeia (EurActiv, 2012a). Sem que haja um reconhecimento da centralidade política destes atores, não há como afirmar que seus discursos sejam fundamentais na construção de significados de segurança na Europa. Deste modo, Neal se pergunta: "Do EU institutions have the capacity to mobilize intersubjective fears and insecurities? Can they, through securitizing moves, produce and shape legitimacy for policies that would otherwise be contentious?" (Neal, 2009, p. 338). Ambas as respostas, para o autor, são negativas. Como será visto no próximo capítulo, Neal argumenta que a Frontex não foi resultado da securitização da imigração na Europa após os atentados de 11/09, mas sim da falha na tentativa de securitização. A rationale em torno da construção da Frontex não foi de políticas de exceção ou situações de urgência, o que se reflete na linguagem empregada nos trabalhos desta agência: não há clamor por medidas emergenciais, mas sim a identificação de um cenário de risco para as instituições europeias.

Nas críticas à lógica da securitização, outras questões podem ser ressaltadas, entre elas, a falta de definição acerca da audiência europeia e as diferenças entre os mecanismos de governança nos Estados e na UE. Sobre o primeiro ponto, Léonard (2010) afirma não ser possível estabelecer uma relação causal entre os atos de fala e as respostas da audiência, pois esta é fragmentada e, em nível europeu, desmobilizada. Sobre o segundo ponto, a autora afirma que o sistema de governo da UE não reproduz os mecanismos de checks and balances existentes nos regimes democráticos e a Comissão não tem as mesmas competências que os governos nacionais, o que dificulta o uso do conceito de estado de exceção. Não há eleições diretas para a Comissão ou para o Conselho e o único órgão no qual os cidadãos europeus tem uma relação direta com seus representantes, o Parlamento, tem suas prerrogativas legislativas bastante reduzidas. Além disso, em temas mais sensíveis à soberania nacional, os Estados ainda detêm capacidade autônoma de decisão. Esta capacidade se estende aos debates acerca da livre circulação de fronteiras, uma vez que o Acordo de Schengen prevê casos nos quais os governos podem reerguer os controles de 
fronteira por um período limitado sem que os demais países tenham poder de vetar esta ação ${ }^{113}$. Léonard afirma ainda que os países da UE tem experiências muito distintas em relação à imigração, o que, por si só, diminui a influência de um discurso de segurança que englobe toda a União. Um mesmo argumento é interpretado de formas diferentes nos países mais desenvolvidos, destino final onde a maioria dos imigrantes busca emprego; nos países de fronteira, nos quais o controle dos fluxos migratórios afeta diretamente a população local; e nos países do norte, onde este ainda não está entre os principais temas na agenda política ${ }^{114}$.

Portanto, revela-se uma série de dificuldades que devem ser consideradas por estudos que observem a dinâmica política da UE através das lentes da securitização. Ao considerar as três etapas descritas por Wæver e Buzan (identificação de discurso acerca de ameaças existenciais, aceitação pela audiência e adoção de medidas excepcionais) Neal e Léonard afirmam que nenhuma delas é claramente identificável no caso das políticas europeias. Conforme visto, os líderes europeus não tem a mesma influência e prerrogativas de ação que os chefes de estado, a audiência é pouco articulada e a Comissão não pode aprovar medidas de emergência para lidar com situações de crise. Deste modo, trata-se de uma ferramenta analítica relativamente limitada.

Nesse sentido, o uso da teoria da securitização deve ser feito com mais cuidado do que ocorre atualmente. Por mais que esta abordagem contribua para a crescente pluralidade nos estudos de segurança e apresente um potencial explicativo, esta visão limita o foco da pesquisa somente à análise de discurso de atores em posições centrais no cenário político, o que impossibilita a compreensão de formas alternativas de construção de significados. Deste modo, esta não pode ser a única chave de leitura.

\footnotetext{
${ }^{113} \mathrm{O}$ restabelecimento das guardas de fronteira pode ocorrer caso o Estado identifique ameaças à segurança nacional ou à ordem pública. Esta decisão é apenas temporária, mas não pode ser banida pelos órgãos da UE. No texto da Convenção para a aplicação do Acordo, consta que: “[...] where public policy or national security require a Contracting Party may, after consulting the other Contracting Parties, decide that for a limited period national border checks appropriate to the situation shall be carried out at internal borders. If public policy or national security require immediate action, the Contracting Party concerned shall take the necessary measures and at the earliest opportunity shall inform the other Contracting Parties thereof' (Diário Oficial da União Europeia, 22 de setembro 2000, p. 133-134, grifo nosso). Para mais ver também artigo $25^{\circ}$ do Acordo de Schengen.

${ }^{114} \mathrm{O}$ tema da imigração gera controvérsias neste grupo de países, mas ao contrário do que ocorre na Alemanha e na França (destino desejado pela maioria dos imigrantes) ou na Grécia, Espanha e Itália (países onde as políticas de controle de fronteiras são muito visadas), a questão da imigração não compete com a crise econômica pelo topo da agenda (Economist, 2012).
} 
As críticas pós-positivistas à Escola de Copenhague propõem uma abordagem bastante distinta para o processo de construção de significados de segurança. Esta abordagem, marcada pelas produções acadêmicas de sociólogos franceses, foi incorporada à disciplina das Relações Internacionais a partir dos anos 2000, sendo influenciada pelas definições de Michael Foucault (2008) e Pierre Bourdieu (2001) acerca da racionalidade governamental e dos meandros burocráticos responsáveis pela expansão do campo da segurança. Estas leituras não negam as contribuições de Wæver e Buzan, mas buscam explicar o processo de construção de conhecimento por uma via bastante distinta.

De fato, é possível identificar momentos em que a lógica da securitização incidiu no processo de tomada de decisão, porém sua ocorrência é muito mais rara do que a literatura especializada faz crer. É preciso que haja critérios mais rígidos para a análise da influência dos discursos de segurança, pois, sem um estudo atento, o analista é levado a sobrevalorizar a responsabilidade de líderes na alteração do quadro jurídico vigente. Além disso, conforme dito anteriormente, só observar momentos em que mudanças políticas acontecem faz com que sejam ressaltados elementos ou dinâmicas específicas que não dão conta de todo o contexto político no qual as transformações ocorrem.

Discursos demandando medidas mais severas para a garantia da segurança de um objeto são bastante recorrentes, mas, na maioria das vezes, passam relativamente despercebidos pela população. Em estudo sobre a atuação de parlamentares europeus, Tsoukala (2004) demonstra que esta é uma atitude corriqueira em meio aos debates, sendo uma estratégia para que determinado tópico ganhe prioridade. Isso não quer dizer que os processos de securitização sejam comuns na União Europeia. O importante ao analisar estes discursos é buscar os padrões de significados que se repetem para, somente assim, poder apontar mudanças. A pesquisa de Tsoukala, ao trabalhar com intervenções de parlamentares nos debates sobre medidas de anti-terrorismo no período entre 05 de setembro de 2001 e 12 de março de 2003, tem como objetivo justamente melhor fundamentar os argumentos acerca de inovações aprovadas para políticas de segurança. A partir desta análise mais longa sobre os discursos e da comparação destes com as medidas postas em prática pela UE, a autora percebe que muitas das posições tomadas após os atentados contra os Estados Unidos apenas confirmaram demandas já apresentadas ao público no dia 05 de setembro, 
coincidentemente, seis dias antes das ações da al-Qaeda. Desta forma, a autora argumenta que, apesar de os atentados terem influenciado o cenário político europeu, não houve um processo de securitização, mas sim o fortalecimento de demandas já existentes na classe política europeia.

Além disso, como será abordado na próxima seção, é fundamental analisar as bases conceituais sobre as quais os discursos são construídos. Posicionamentos acerca da ameaça de imigrantes para a Europa não surgem fora de um contexto social, mas sim imersos em uma complexa teia de argumentos que, na maioria das vezes, não operam como atos de fala. Há um aspecto central neste processo que Buzan e Wæver ignoram:

"[...] securitization in discourse can legitimize the use of certain security practices. But this public legitimation does not have to be a precondition for such practices. Indeed, administrative agencies may have substantial scope for action without being held accountable to public or judicial scrutiny" (Boswell, 2007, p. $593)$.

Ou seja, mesmo quando há a caracterização de determinado fenômeno como uma ameaça, este processo não se dá somente a partir dos dispositivos do ato de fala, mas sim por uma convergência de significados que envolve mecanismos complexos. Estes serão mais bem trabalhados na próxima seção, porém já é possível afirmar que a postura adotada por líderes é apenas um elemento, não devendo ser privilegiada em detrimento de pesquisas acerca da postura de outros atores sociais menos visados pelo público.

Assim sendo, esta abordagem sociológica, principalmente de Bigo (2002, 2008, 2010b), Huysmans (1998b, 2000, 2006a), Boswell (2007a, 2007b) e Léonard (2010), reconhece o impacto dos discursos na construção dos significados sociais de determinado fenômeno, mas questiona o foco dado aos atos de fala e o monopólio dos líderes como atores capazes de moldar o entendimento coletivo. Assim, busca-se o diálogo com a Escola de Copenhague no que tange à construção social do campo da segurança, concordando que esta apresenta uma teoria que abrange o impacto dos códigos simbólicos na formulação dos discursos. No entanto, os autores mencionados também questionam a falta de reflexividade na postura de Wæver frente às lógicas que 
conformam estes códigos e os parâmetros dos discursos sobre segurança. Sem este exercício reflexivo, não há como entender o processo de produção de significados, nem a forma pela qual determinado campo de conhecimento é estruturado (C.A.S.E Collective, 2006).

No caso das análises acerca das políticas de controle de fronteiras na União Europeia, a falta de estudos sobre a forma pela qual o campo é estruturado leva a análises que não inserem a Frontex no contexto interinstitucional mais amplo em que esta agência opera, e sem o qual seu trabalho não pode ser totalmente entendido. Esta simplificação da realidade pode ser apontada como uma armadilha teórica, que leva os pesquisadores a ignorarem as disputas por construção de significados e, logicamente, as consequências destas disputas para o fortalecimento de argumentos soberanos. Portanto, como será visto no quarto capítulo, mais que uma limitação para a ferramenta analítica da securitização, a falta de reflexividade acaba por reproduzir a hierarquia de atores em determinado espaço social, o que resulta também no privilégio de alguns padrões de conhecimento em detrimento de outros, fortalecendo relações de dominação e restringindo as alternativas políticas.

Deste modo, a abordagem sociológica se distancia da Escola de Copenhague e opta por incorporar uma perspectiva, em parte, materialista do objeto de referência da segurança. Para entender esta alternativa teórica, a próxima seção buscará alguns elementos do trabalho de Bourdieu, principalmente suas contribuições acerca da dimensão material das práticas sociais, que são recuperadas nos estudos sobre segurança internacional.

\subsection{Bourdieu e uma leitura alternativa para a segurança internacional}

"Theorization is the pleasure of understanding everyday practices" (Bourdieu apud Bigo, 2011, p. 232).

A sociologia política internacional, cujo grupo voltado para a área de segurança ficou conhecido como Escola de Paris, propõe um fazer teórico que rompa com as premissas do positivismo, mas que também não incida nas limitações do construtivismo convencional, apresentado por muitos dos autores da Escola de Copenhague. Trata-se de uma abordagem que, ao invés de fazer uma 
análise pura de discursos, focando no papel da linguagem para a construção social, prioriza o estudo da forma pela qual as relações de poder se constituem e são reproduzidas através das práticas diárias dos atores. Há uma mudança de foco, na qual o pesquisador não observa momentos específicos em que novos significados coletivos são produzidos, mas sim o longo processo pelo qual campos de conhecimento são estruturados.

Nesse sentido, a Escola de Paris afirma ser necessário repensar as bases vigentes do debate entre positivistas e pós-positivistas, levando os pesquisadores a refletir sobre o atual processo de articulação entre teoria e metodologia e evitando dicotomias simplistas ou declarações dogmáticas (Bigo, 2011). Argumenta-se que mesmo as abordagens críticas da segurança internacional devem ser revistas, aprimorando sua capacidade de compreensão da política contemporânea e apontando alguns de seus vazios teóricos. Para tanto, propõe-se uma reflexão acerca das possíveis contribuições dos conceitos de campo e habitus, conforme formulados por Bourdieu, para o estudo sobre o impacto das disputas por poder entre profissionais de segurança na construção de conhecimento a respeito de ameaças. Esta reflexão está alicerçada na percepção de Bourdieu de que existem estruturas objetivas operando independetemente da consciência dos agentes, mas estas "são produtos de uma gênese social dos esquemas de percepção, de pensamento e de ação. [...] as estruturas, as representações e as práticas constituem e são constituídas continuamente" (Thiry-Cherques, 2006, p. 28). Esta aparente contradição será compreendida a seguir.

\subsubsection{Campo, Habitus e o estudo das práticas}

Pierre Bourdieu foi um sociólogo bastante ativo na segunda metade do século XX e, tendo proposto novas formas de pensar a articulação entre teoria e práticas sociais, influenciou diversas áreas do conhecimento. Sua atuação multidisciplinar contrariou a tendência da maioria da sociologia crítica francesa da qual foi contemporâneo, contestando aqueles que proclamavam o fim da cientificidade e da objetividade nas ciências humanas. Guiado pela convicção de que o ofício do sociólogo é, fundamentalmente, denunciar as relações de 
dominação ${ }^{115}$, Bourdieu procurou desenvolver um conhecimento praxiológico capaz de unir o subjetivismo e o objetivismo ${ }^{116}$. Através de um "fazer teórico como prática", Bourdieu esperava romper com as dicotomias conceituais que marcavam os debates vigentes ${ }^{117}$. Nas palavras do autor:

"The theory of practice as practice insists, contrary to positivist materialism, that the objects of knowledge are constructed, not passively recorded, and, contrary to intellectualist idealism, that the principle of this construction is the system of structured, structuring dispositions, the habitus, which is constituted in practice and is always oriented towards practical functions" (Bourdieu, 1990 [1980], p. $3)$.

O trabalho de Bourdieu serviu como base para algumas perspectivas alternativas da disciplina de Relações Internacionais, especialmente na área de segurança, que foram responsáveis por dar uma nova dinâmica aos debates teóricos. A partir do arcabouço conceitual do sociólogo francês, não apenas Bigo, mas também autores como Anna Leander $(2009,2011)$ e Virginie Guiraudon (2001) oferecem uma abordagem que incorpora os aspectos materiais e ideacionais das relações de poder, rompendo com os extremos do construtivismo reflexivo e das leituras positivistas. Indo além, estes autores buscam uma análise que considere um papel distinto para o Estado, concebendo este como um (entre muitos) campo de disputa por poder simbólico.

O poder simbólico está relacionado ao entendimento que os indivíduos possuem acerca do contexto político em que estão inseridos. Este entendimento

\footnotetext{
${ }^{115}$ Outro debate importante no qual Bourdieu tomou parte envolveu a crítica às tradições marxistas na sociologia. Estas percebem o espaço social de forma unidimensional, onde as relações são orientadas pelo modo de produção e as contradições por ele geradas. Seguindo estes parâmetros teóricos, as agendas de pesquisa observavam os fenômenos sociais a partir de processos socioeconômicos e da luta de classes. Embora elogiasse o duplo papel de teórico/político de muitos marxistas, Bourdieu criticava a pobreza e o determinismo destas análises, afirmando que o espaço social é multidimensional, sendo as relações de classe apenas uma destas dimensões (Bourdieu, 2001).

${ }^{116} \mathrm{O}$ trabalho de Bourdieu parte da crítica a diversas correntes teóricas relevantes na época. Sendo assim, o autor rompe com o "[...] estruturalismo (rejeitado em sua forma extrema em razão da redução objetivista, que nega a prática dos agentes e retém as imposições estruturais); ao interacionismo (recusado por considerar que os agentes não são portadores de nenhuma determinação social e por omitir a gênese socias); ao subjetivismo (rejeitado por forjar o mito de um sujeito sem história e sem determinantes); à fenomenologia (por vê-la como exclusivamente descritiva, constituindo-se somente numa etapa da pesqiuisa)" (Valle, 2007, p. 124).

${ }^{117}$ Estes serão mais detalhados à frente, mas pode-se adiantar os principais: indivíduo/sociedade e ação/estrutura.
} 
define os interesses e os mecanismos para buscá-los. Assim, o Estado e as instituições existem, pois são vistos como organizações sociais capazes de alcançar e garantir alguns dos interesses. No entanto, mudadas as regras do jogo, ou seja, dados novos entendimentos acerca dos contextos sociais, o Estado poderia perder sua razão de ser. O poder simbólico é justamente a capacidade de alterar os interesses dos indivíduos e, assim, transformar as relações de poder vigentes na sociedade (Leander, 2009).

Desta forma, ao invés de tentar compreender a dinâmica que rege as articulações políticas nos níveis doméstico e internacional - mantendo o Estado como paradigma -, esta abordagem tem como objetivo central analisar os mecanismos pelos quais os "entendimentos coletivos" se configuram e como o poder simbólico interfere no processo de construção de novos significados. Tratase de uma forma politicamente engajada de fazer ciência, que nega a possibilidade de neutralidade na produção de conhecimento e rejeita a adoção do padrão dicotômico no pensamento social (ator/estrutura, material/ideacional, objetividade/subjetividade). Bourdieu busca atuar nos dois lados, formulando teses que levem à luz as relações de poder e, portanto, que permitam a articulação da resistência e da emancipação ${ }^{118}$.

Análises que não se comprometam com a forma pela qual a política se desenvolve no dia-a-dia ou, nas palavras de Bigo, "statements about what the world means that are given from the 'armchair"” (Bigo, 2011, p. 227), não são capazes de abranger o comportamento dos diversos atores sociais e seu impacto na política. Só é possível entender como se constrói a legitimidade de determinado discurso a partir de estudos empíricos, e da análise histórica da construção dos significados que criaram as condições de possibilidade para que este discurso fosse proferido e compreendido pela população. Sem esta árdua tarefa, os pesquisadores são capazes apenas de apontar argumentos de autoridade sem compreender o contexto no qual estes são produzidos.

A fusão entre trabalhos empíricos, com uso extenso de dados, e as abordagens reflexivas se dá pois, para Bourdieu, "constructivism exists in the practice of questioning the results of empirical sociological inquires with a very

\footnotetext{
${ }^{118}$ Para uma análise da trajetória profissional e política de Bourdieu, ver Leander (2008). Neste mesmo texto, Leander apresenta a variedade de temas das Relações Internacionais nos quais há trabalhos sendo desenvolvidos segundo as bases teóricas propostas por Bourdieu. Estes são, em sua maioria, de pesquisadores com origem em outras áreas, como sociologia, direito e economia.
} 
high level of reflexivity about both their own conditions of production and their own limits" (Bigo, 2011, p. 227). Desta forma, Bourdieu avança uma perspectiva materialista do construtivismo, distinguindo seu trabalho de reflexão empírica acerca da "sociologia das práticas" do construtivismo mais comum à disciplina de Relações Internacionais (com bases teóricas idealistas), que observam o impacto de normas e da linguagem. Através dos conceitos de campo e habitus, é possível aprofundar esta leitura alternativa.

O conceito de campo tem sido utilizado como referência para uma determinada área de interação social onde os indivíduos são unidos por um questionamento específico. Este funciona como uma espécie de força magnética, sendo um centro em torno do qual as dinâmicas sociais são construídas. O escopo do campo pode ser bastante variado (uma família, categoria profissional ou até mesmo o Estado), sendo necessário apenas que haja uma lógica de organização social na qual se baseie um entendimento implícito ou explícito do mundo (um senso comum ou $\left.d o x a^{119}\right)$. O compartilhamento de significados é responsável por uma coerência na construção dos interesses e na percepção do que é o poder (autoridade dos pais, diploma universitário, cargo executivo), sem que estas questões sejam constantemente problematizadas. O capital social que se articula a partir dos significados coletivos de determinado campo faz com que as relações de poder sejam invisíveis ou pareçam naturais (relação pai/fillho, patrão/empregado, cidadão/representante). A definição de Leander resume de forma clara este conceito:

“[...] a field is an organizing logic around a 'stake at stake', visible through its effects and dominating everyone concerned by the stake at stake whether or not they are conscious of participating in the field and/or actively engaged in the struggle for defining that stake" (Leander, 2009, p. 4).

A incorporação de uma visão parcialmente materialista acerca do processo de construção social sofreu críticas por parte de autores que focam na capacidade transformadora dos discursos, especialmente nas bases conceituais de Derrida (ver Taureck, 2006). Este grupo de autores afirma que a contribuição de Bourdieu para

\footnotetext{
${ }^{119}$ Bourdieu define este conceito como "an adherence to relations of order which, because they structure inseparably both the real world and the thought world, are accepted as self-evident" (Bourdieu, 1984, p. 471)
} 
a área de segurança internacional estaria próxima da teoria da escolha racional e, consequentemente, dos argumentos centrais de neorealistas e liberais. Esta visão, no entanto, esbarra na definição de Bourdieu acerca da ação social como um conjunto de práticas imanentes nos variados campos, o que não se aproxima da lógica de escolha racional. As práticas imanentes, ou o habitus, funcionam como o reflexo de um jogador de tênis, que realiza sua jogada não a partir da análise e antecipação do comportamento do adversário, mas sim pela repetição de ações passadas. O momento de decisão, no qual o jogador opta por bater na bola para que ela siga determinada trajetória, não tem nenhuma semelhança com o que a literatura de escolha racional prevê (cálculos de custos de benefícios). Trata-se de uma prática baseada na intuição (Bigo, 2011).

Para Bourdieu, os indivíduos tem uma disposição de ação pautada em suas experiências nos variados campos. Esta disposição é o que relaciona significados sociais desarticulados ${ }^{120}$ a um determinado comportamento. O campo é o contexto no qual um habitus ganha sentido e passa a ser internalizado por aqueles que reproduzem suas regras e discursos, mas a natureza deste habitus é complexa, variando de indivíduo para indivíduo. Segundo a ampla definição formulada por Leander:

"The habitus is an inclination, a disposition, to see, talk, taste, do or work in a specific ways. It is a background matrix that shapes what is understood to be rational or to be right and wrong. The habitus also shapes views on painting, music, literature or politics. Lastly, the habitus shapes the body and body language by shaping how people care for themselves [...] but also how they understand gender, race or sexuality. Since body expression is integral to social positions, the habitus can readily be seen as a form of 'incorporated capital' in a ideational but also in a physical sense" (Leander, 2009, p. 7).

Bourdieu (1986) compreende o habitus não como resultado do livre-abítrio ou da determinação do campo, mas sim como um meio termo entre estes dois condicionantes que se desenvolve a partir da interação ao longo do tempo. O autor afirma que o habitus é marcado pelos eventos passados e pelas estruturas sociais, o que influencia as práticas atuais, mas, ao mesmo tempo, influencia os campos e

\footnotetext{
${ }^{120}$ Desarticulados, pois são fruto da interação entre os diferentes capitais sociais dos variados campos dos quais um indivíduo faz parte.
} 
as percepções dos indivíduos. Assim, habitus pode ser também definido como "the mental structures through which (an individual) apprehend(s) the social world $[. .$.$] essentially the product of the internalisation of the structures of that$ world" (Bourdieu, 1986, p. 130). Trata-se de uma mediação que atribui razão às práticas dos agentes, tornando-as sensatadas e objetivas dentro de um campo. Da mesma forma, esta disposição de ação é também formada por forças coletivas e determinações individuais, sendo

"[...] the product of the incorporation of objective necessity, of necessity turned into virtue, produces strategies which are objectively adjusted to the objective situation even though these strategies are neither the outcome of the explicit aiming at consciously pursued goals, nor the result of some mechanical determination by external causes. Social action is guided in a practical sense, by what we may call 'feel of the game" (Leander, 2010, p. 5).

Cada indivíduo, através de suas variadas experiências, tem um habitus único, que não é repetido em sua totalidade por nenhum outro. No entanto, dentro de determinado campo, os variados habitus tem relação entre si. Assim, os indivíduos possuem um sentido prático que representa a sobreposição de estruturas de poder nos campos nos quais eles interagem e, ao atuarem nos variados campos, contribuem para a sua dinâmica. O habitus implica na resposta à ação dos outros, mas não necessariamente de forma consciente. Não se trata de um movimento no jogo de xadrez. Também não é um ato decorrente da análise estratégica sobre possíveis alianças e formas de atingir objetivos. O habitus é

"[...] a practice coming form the inner knowledge of the field and the hysteresis of the behavior concerning the transformation of its boundaries. The habitus is a collective embodiment as much as the field is a field of individuals, but it generates creativity" (Bigo, 2011, p. 241).

Trata-se de uma disposição para a ação, que se dá a partir da repetição das práticas em determinado campo, o que é possível através do conhecimento histórico a respeito deste campo. Nesse sentido, o habitus é o molde sob o qual a ação do indivíduo ou instituição será produzida, mas não define a substância desta 
ação, ou, como colocado por Bigo, "habitus is the grammar not the text, [...] a repertoire, but not a melody" (Bigo, 2011, p. 242).

Segundo Bourdieu, os conceitos de campo e habitus devem ser pensados de forma conjunta, não como representações separadas de agente e estrutura, mas sim como a forma pela qual estes interagem. O campo é o espaço das práticas coletivas, mas é formado pelos indivíduos e instituições, não existindo um independente do outro. Nas palavras do autor,

"In analytical terms a field can be defined as a network, or a configuration, of objective relations between positions. These positions are objectively defined, in their existence and in the determinations they impose upon their occupants, agents or institutions, by their present or potential situation (situs) in the structures of distribution of species of power (or capital) whose possession commands access to the specific profits that are at stake in the field, as well as by their objective relation to other positions (domination, subordination, homology, etc.)" (Bourdieu \& Wacquant, 1992, p. 97).

Apesar de se pautar no arcabouço teórico de Bourdieu, Bigo faz uma reserva e afirma que esta definição realça o caráter objetivo do campo, como uma estrutura já formada que se impõe aos agentes. Para evitar esta limitação teórica, Bigo propõe uma leitura que enfatize o espaço de disputas por poder, operando com forças centrípetas e centrífugas. A melhor representação do campo seria uma rede, onde os agentes estão conectados, mas mantém autonomia ${ }^{121}$. Há um permanente atrito entre os agentes mais influentes que tentam dar sentido à organização vigente e evitar a mudança da lógica interna. A manutenção dos significados sociais é, portanto, fruto desta disputa de poder, na qual os soberanos são contestados, mas ainda mantém a capacidade de atração. As mudanças de significados ocorrem quando as forças centrífugas superam a capacidade dos atores mais poderosos em manter a hierarquia vigente. Nesse caso, as fronteiras do campo são suspensas e novos significados podem ser construídos. O exemplo exposto anteriormente sobre o Estado se aplica, pois este se constitui como um campo contingente, que tem sua existência definida pelas relações de poder vigentes. Uma vez que estas relações sejam alteradas, novas estruturas sociais

\footnotetext{
${ }^{121}$ Há uma vasta literatura que debate a questão da autonomia no trabalho de Bourdieu. Para mais, ver Pinto (2000) e Warde (2001).
} 
podem ser criadas. Os campos vivem, portanto, em uma permanente disputa, sendo constituídos a partir das relações internas, mas também das intervenções de outros campos e atores. Nesse sentido a dinâmica é a regra e a estabilidade a exceção (Bigo, 2011).

Neste cenário, os indivíduos estão em constante busca pela definição dos interesses e por mais poder simbólico. Esta se dá através da incorporação de significados produzidos nos diversos campos dos quais os indivíduos fazem parte (afinal, um médico não é apenas um médico, mas também um pai, um eleitor e etc). Ou seja, os campos existem dentro de um contexto mais amplo (o espaço social), no qual as fronteiras internas estão em eterna negociação. Esta negociação se dá a partir de uma hierarquia entre os campos, sendo alguns capazes de produzir um capital social que influencia todos os demais (condição financeira, nível educacional e etc.). Sua autonomia, portanto, é apenas parcial, uma vez que as disputas se dão entre os indivíduos e entre os próprios campos. Nesse sentido,

\footnotetext{
"o campo deve ser entendido como um espaço de lutas, onde a relação entre as posições é marcada pela distribuição assimétrica dos diferentes tipos de capital (a forma como os diferentes tipos de capitais se combinam é uma propriedade específica de cada campo) e definem suas relações através de estratégias que visam mobilizar seus estoques de capital, a partir das propriedades do campo, para reforçar suas posições tanto nesses quanto nos outros campos e no espaço social como um todo" (Dario, 2009, p. 10-11).
}

Compreendida a relação entre habitus e campo, é possível afirmar que Bourdieu rompe com as dicotomias entre razão e emoção, ato consciente e prática espontânea. O que define as ações é a reprodução de trajetórias históricas, a manutenção de um processo de legitimação de determinadas ações e regras. Nesse sentido, o valor das normas é considerado na definição das práticas sociais, mas não é desenvolvido segundo os mesmos parâmetros definidos por Derrida e adotados por Wæver. A diferença proposta por Bourdieu está no fato de este autor incorporar a linguagem como mais um fenômeno sócio-histórico, não como uma representação exata da consciência dos atores. Como explica Bigo, 
"Norms neither follow rational interests nor emerge from shared beliefs and attitudes, and are even less the result of their dialectical relations. They are the product of the strength of the historical trajectories of an immanent set of actions incorporated into an ethos and a habitus" (Bigo, 2011, p. 228).

Assim, apesar de elogiar o comprometimento com o qual os positivistas desenvolvem estudos empíricos e incorporar o intenso estudo de dados e muitas das contribuições dos estudos quantitativos em seu trabalho, Bourdieu alega ser necessário também considerar metodologicamente as abordagens qualitativas, com realização de entrevistas e análises de documentos que permitam compreender as práticas discursivas que conformam determinado contexto político. Logo, para Bourdieu, uma análise bem fundamentada não deve ser definida por uma visão idealista do mundo, para a qual a subjetividade é o foco das ciências sociais, nem por um paradigma objetivo e estruturalista, que acaba por adotar uma essência do comportamento humano e descrever leis gerais da história. Este autor compreende a política como uma prática mais densa, que precisa de ferramentas de análise mais adequadas do que as apresentadas pelas duas principais correntes das ciências sociais (Bourdieu, 1986).

Deve-se, portanto, privilegiar um fazer teórico que vise a romper com o quadro analítico binário descrito anteriormente, no qual a dicotomia opera em prol do fortalecimento de seus dois extremos e na anulação de qualquer espaço que não esteja comprometido com um dos lados. O esforço para romper com esta organização do campo teórico deve começar através da superação da visão tradicional de afastamento entre teoria e prática. Bourdieu argumenta que muitos dos conceitos teóricos vistos como neutros são derivados de terminologias das burocracias estatais, ou seja, a produção de conhecimento que alega ser separada da prática é, em larga medida, fruto das limitações impostas pela definição do que seria o conhecimento legítimo. Além disso, conceitos formulados por teóricos, uma vez empregados no cotidiano político, acabam tendo seu significado alterado, tornando-se categorias jurídicas e instrumentos para formulação da política estatal (Warde, 2011). Em outras palavras:

"The bureaucratic or mundane categories that are elevated to the status of a 'concept' by academics and lawyers are not the result of a sovereign capacity by 
a locutor to have a successful speech act imposing them as knowledge producing truth. They are even less the product of a consensus/dialogue of an epistemic community leading toward an objective regime of truth whose model will be equivalent to logic and mathematics. Rather, they are nearly always the product of relations and the circulation of power inside and between fields, as well as an imposition of problems coming from dominant positions" (Bigo, 2011, p. 231).

Ou seja, para Bourdieu, as pesquisas devem ser pautadas em um construtivismo crítico, mas também pela extensa pesquisa empírica, sendo esta a única forma de evitar os atuais vazios e silêncios do campo da segurança. Assim, se faz necessária uma atenção com a metodologia a ser empregada nas pesquisas. Não há uma regra geral que possa ser decifrada para a compreensão dos fenômenos sociais. Conforme visto anteriormente, é fundamental que o pesquisador utilize ferramentas distintas e heterogêneas, unindo dados quantitativos e interpretações resultantes de estudos qualitativos. Deve ser incorporado o uso de estatísticas, entrevistas etnográficas e pesquisas em arquivos históricos, pois analisar um campo supõe a busca por "homology between the objective positions and the discourses and position takings of the agents" (Bigo, 2011, p. 245). Esta é uma questão especialmente cara a Bourdieu, que chega a afirmar não haver valor em trabalhos sem rigor científico na construção do objeto de pesquisa (Bourdieu, 2001). Em outro momento o autor afirma ainda ser fundamental "rejeitar a arrogância do sociólogo que recusa sujar as mãos na cozinha da empiria” (Bourdieu apud Valle, 2007, p. 120).

Em resumo, a contribuição de Bourdieu com maior impacto na disciplina de Relações Internacionais é sua predileção por iniciar as análises a partir do "meio". Trata-se de uma postura metodológica que enxerga nas relações e não nos agentes ou estruturas as principais chaves para explicação dos fenômenos. Assim, é possível romper com a dicotomia que tem marcado as RIs nas últimas décadas. Sem pautar as análises no debate sobre o que deve ser privilegiado (estrutura ou agência), Bourdieu propõe que o foco seja na trajetória de um padrão de ação. Somente a partir da compreensão do desenvolvimento histórico de determinada prática, é possível compreender momentos de transformação.

Esta abordagem se revela nas recomendações para a análise da organização interna e das relações de poder nos campos. Segundo Bourdieu, é 
preciso especificar as "posições" de cada agente e seu grau de influência sobre os demais (Bigo et al, 2007; Venturini \& Latour, 2010). Ao estabelecer as conexões e as relações de poder do campo, é possível produzir um mapa. No entanto, como os campos são extremamente dinâmicos, os mapas servem apenas como indicação de sua estrutura organizacional em um momento específico. São retratos que envelhecem na medida em que a luta por capital simbólico é travada.

\subsubsection{Política, Estado e agências burocráticas}

Ao identificar o Estado como um campo de práticas, onde diferentes capitais sociais são convertidos em um único centro organizacional, a obra de Bourdieu ganha espaço central na análise do processo de formulação de políticas. Deste modo, é possível afirmar que os agentes do Estado possuem um poder simbólico sobre a produção de novos significados e sobre a legitimação do conhecimento válido. Esta questão é central e tem influência na forma como as pesquisas acadêmicas são desenvolvidas. Por exemplo, informações sobre imigrantes produzidas por institutos estatais de gerenciamento de dados são a primeira fonte para as análises e o modelo utilizado para as estatísticas oferecidas por outras instituições. Por conseguinte, um estudo sobre o impacto da imigração nos países europeus passa pela narrativa estatal sobre este fenômeno e, fundamentalmente, pela incorporação do conhecimento produzido pelo Estado e/ou a partir das categorias sociais estabelecidas pelo Estado ("estrangeiro/nacional", "legal/ilegal" e outras). Assim sendo, mesmo adotando uma postura crítica em relação às categorias analíticas vigentes, ao valer-se de modelos estadocêntricos, muitos estudos acabam contribuindo para o poder simbólico do Estado, reificando seu lugar como produtor legítimo de conhecimento.

Bigo recupera o trabalho de Bourdieu justamente por este motivar o estudo do Estado não como um ator, mas sim como um campo em disputa, onde a dinâmica entre profissionais da política ${ }^{122}$, burocratas, agentes privados e

${ }^{122} \mathrm{O}$ uso do termo "profissionais da política" é uma reprodução da terminologia empregada por Bigo em suas análises. Este termo se explica dada a perspectiva sobre a atuação destes atores que não vivem para a política, mas sim da política. Segundo Bigo, "They tend to monopolize the representation of groups coming from different social universes and select what is considered in their world as political" (Bigo, 2011, p. 246). 
representantes da sociedade civil, na busca por acesso aos mecanismos do poder, opera no sentido de fortalecer o capital simbólico deste campo como legítimo produtor de significados.

Bigo busca ainda complementar esta interpretação salientando que a centralidade do Estado é também fruto da crença na democracia e na representação, pela qual a sociedade poderia ter sua pluralidade refletida nas instituições. Para o autor, o campo da política não é democrático (ao menos não da forma transparente como os teóricos da democracia-liberal fazem crer) e a representação, ao ser constrangida pelos canais oferecidos pelo próprio Estado, é ilusória. O Estado é, por um lado, controlado por profissionais da política, agentes que filtram a participação e os interesses dos cidadãos, atuando no sentido de reproduzir seu acesso ao poder, e, por outro, por técnicos, indivíduos não-eleitos, que conduzem a burocracia e operam este campo. Nesse sentido, pode-se afirmar que:

\begin{abstract}
"Representation is then the most powerful construction of a political myth concerning freedom, equality and democracy, and it is through this logic of the neutralization of the role of the spokesperson that representation institutes that people continue to believe in the existence of the state as the locus of the "liberal democratic" national state where representation is expressed through techniques of democracy [...]" (Bigo, 2011, p. 246).
\end{abstract}

Ao contrário do que ocorre na teoria de securitização da Escola de Copenhague, Bigo considera os dois grupos de agentes sociais - profissionais da política e burocratas/técnicos - como produtores de conhecimento a partir do Estado. A mudança de perspectiva proposta pela Escola de Paris é analisar os campos burocráticos como emancipados da autoridade dos profissionais da política. Desta forma, o conhecimento técnico torna-se mais um campo de disputa de poder, que é ainda mais relevante por, apesar de trabalhar no sentido de reforçar o lugar do Estado, se constituir a partir de relações globais.

Este campo de profissionais é formado por redes transnacionais estruturadas a partir de burocracias híbridas que incorporam atores públicos e privados. As redes de profissionais promovem encontros internacionais, nos quais organizações e técnicas são compartilhadas, o que permite a acumulação de um 
capital simbólico sobre a informação. No caso dos agentes de segurança, o resultado é a concentração da produção legítima de conhecimento acerca dos mecanismos para lidar com o risco e gerenciar as ameaças, que substitui a retórica dos profissionais da política acerca dos dispositivos legais para lidar com estes temas.

No âmbito da União Europeia ${ }^{123}$ há uma interposição de campos que complexifica as pesquisas sobre o processo de produção de conhecimento sobre segurança. O habitus dos atores segue padrões domésticos e internacionais. Desta forma, eles são sempre "agentes duplos", atuando de formas distintas na interlocução com o campo do Estado e da UE. Este contexto, ao invés de reduzir a legitimidade deste atores, contribui para que seu capital social seja ainda mais significativo. Seu trânsito entre os diferentes níveis de governo na Europa faz com que sua experiência burocrática ganhe espaço em relação aos atores fixos nos diferentes níveis, o que explica, por exemplo, porque os profissionais de segurança da Frontex tem uma influência tão relevante na formulação das políticas internas e comunitárias de controle de fronteiras. Ilustrando este fenômeno, Bigo afirma que:

"The creation of police 'clubs', and their institutionalization later on, has structured a field of internal security and has lead to a reframing of the relations between police officers, antiterrorist specialists, intelligence services, borders guards and immigration offices". (Bigo, 2011, p. 252).

O capital social dos especialistas da segurança faz com que os Estados sejam cada vez menos guiados pelos profissionais da política e por suas diferenças ideológicas. O espaço dos partidos e lideranças políticas é reduzido, sendo estes somente canais para a disseminação dos significados produzidos por burocracias autônomas. Deste modo, Bigo afirma que a disputa que mais interfere na condução dos Estados europeus atualmente não é entre democrata-cristãos e social-democratas, mas sim entre as burocracias e seus interesses corporativos. A União Europeia contribui ainda mais para esta tendência, facilitando a

\footnotetext{
${ }^{123}$ Este processo também ocorre em outros espaços políticos, mas no seio da UE, por esta criar um ambiente mais propício para o diálogo entre profissionais de segurança, há uma intensificação do intercâmbio e, logicamente, da interposição dos campos.
} 
socialização entre estes profissionais e a padronização dos mesmos ${ }^{124}$. Neste cenário, a abordagem da sociologia política é fundamental para entender os diversos elementos que compõe a dinâmica política internacional.

Trata-se de uma leitura sobre processos de securitização bastante distinta da avançada pela Escola de Copenhague, que não privilegia os discursos dos líderes, mas sim as práticas diárias das burocracias e dos profissionais de segurança. A partir desta reflexão analítica, cabe entender como as perspectivas teóricas apresentadas por Bourdieu podem auxiliar no estudo acerca do desenvolvimento das políticas de imigração na União Europeia e, consequentemente, a criação da Frontex.

124 Em "The European Internal Security Field" (1994), Bigo analisa as trajetórias destes profissionais e demonstra que o grau de interação é altamente relevante, tendo estes atores frequentado as mesmas universidades, comparecido aos mesmos congressos, aos mesmos destinos de férias e, inclusive, estabelecido relações matrimoniais. Assim, desenvolveram um habitus cosmopolita que influencia não só as burocracias europeias, mas pauta também o trabalho das agências nacionais (Bigo, 1994). 


\section{4.}

\section{Imigração como uma questão de segurança: 0 longo processo de convergência entre agendas}

Em outubro de 2004, quando o Conselho Europeu ratificou a criação da Frontex, houve pouca repercussão deste fato em meio à elite política europeia. Esta medida já fora tratada no Parlamento Europeu (Tsoukala, 2004) e nos parlamentos nacionais (House of the Lords, 2003), tendo sido mais relevante o debate acerca da organização interna desta agência e os critérios para a distribuição de cargos, do que as consequências da Frontex para o combate à imigração ilegal, ao crime organizado transfronteiriço e ao terrorismo (House of the Lords, 2008). Dentre as controvérsias sobre a atuação da Frontex, a que suscitou mais críticas por parte dos parlamentares foi a relação desta agência com as forças nacionais de segurança, de modo que mesmo após sua criação, o general Laitinen, recém indicado para o cargo de diretor, visitou diversas casas legislativas para explicar o funcionamento e a forma pela qual a Frontex poderia contribuir para as operações de controle de fronteiras sem que as forças nacionais fossem desprestigiadas (House of the Lords, 2008). O trabalho de convencimento do general finlandês o levou também a procurar os setores militares de diversos países, bem como um diálogo com universidades e think-tanks, para demonstrar que a agência era apenas a evolução lógica das medidas de segurança consagradas ao longo das últimas décadas (Laitinen, 2007).

O discurso de Laitinen faz parte de uma estratégia argumentativa que visa a evitar críticas acerca do trabalho da Frontex, demonstrando que esta seria somente uma modernização das estruturas existentes até então. Sua retórica, portanto, contradiz frontalmente os autores que interpretam a criação da agência como um marco da inflexão política na Europa e resultado de um processo de securitização da imigração no continente. Para Laitinen, a criação da Frontex se deu segundo a lógica do aprofundamento do processo de integração, sendo uma política necessária para garantir o princípio de liberdade interna de movimento no âmbito da UE. Nas palavras do próprio diretor executivo, "Frontex, or something like it, would have come about with or without 9/11" (Laitinen apud Neal, 2009, p. 344). 
Esta visão é reforçada por pesquisadores da área, que veem a Frontex apenas como uma entre as várias ferramentas postas em prática ao longo dos últimos vinte anos para garantir a segurança do espaço único europeu (Guild, 2006b). Tendo ênfase em tecnologia, compartilhamento de dados, acesso à informação e análise de risco, os objetivos e meios de trabalho da Frontex são bastante semelhantes aos de outras iniciativas europeias. Ao longo do período mencionado, ou mesmo antes da assinatura do Tratado de Maastricht, foram criados, entre outros: o SIS, a lista de países dos quais seriam solicitados vistos de entrada, o formato único para vistos de curta duração, o VIS (Visa Information System), as regras comuns para transmissão de dados de passageiros e as convenções de Dublin. Todas estas medidas foram postas em prática a partir de demandas por maior capacidade de monitoramento da mobilidade na área de Schengen e garantiam ferramentas para que os Estados fossem mais efetivos em suas políticas de controle de fronteiras. Conforme será visto a seguir, a Frontex foi criada para potencializar a cooperação neste setor, não para mudar as bases sobre as quais se davam as políticas de segurança. Não à toa, esta agência unificou os diversos centros de operação que atuavam sob o marco da SCIFA+. Segundo a Comissão Europeia, esta reorganização institucional garantiria uma melhor coordenação entre as atividades destes centros e, consequentemente, maior eficiência na vigilância e controle das fronteiras europeias (Comissão Europeia, 2002).

A criação da Frontex, no entanto, não passou despercebida por organizações da sociedade civil que atuam em defesa dos direitos dos imigrantes. Em relatório publicado pela Statewatch, uma importante plataforma para difusão de conhecimento acerca dos problemas relativos aos direitos humanos na UE, Hayes (2003) critica o documento "The development of a common policy on illegal immigration, smuggling and trafficking in human beings, external borders and the return of illegal residents" (Comissão Europeia, 2003), no qual a Comissão Europeia pressiona o Conselho e os Estados a seguirem adiante com os debates sobre a Frontex. Segundo Hayes, a proposta apresentada - que foi aprovada meses depois - diminuiria a transparência das ações nas fronteiras e dificultaria a investigação de casos de violência contra imigrantes e refugiados. A Comissão solicitava a criação de uma agência que pudesse operar segundo normas menos restritivas e com mecanismos de accountability e responsabilização menos 
rígidos. Assim, ao unificar os serviços de diversas instituições já existentes sob novas regras, a Frontex diminuiria a capacidade de averiguação dos diversos órgãos europeus (inclusive do parlamento) e da sociedade civil sobre as políticas de controle de fronteiras, tornando-as ainda menos democráticas. Hayes afirma ainda que através desta manobra institucional, a UE estaria dando vazão a uma “agenda escondida” de expulsão dos indivíduos indesejáveis (Hayes, 2003).

Ao contrário do que ocorreu com as críticas colocadas pelos parlamentares acerca das futuras relações entre a Frontex e as forças nacionais de segurança, as acusações feitas pela Statewatch foram vistas como infundadas por Laitinen e membros da Comissão Europeia. Quando arguidos a este respeito, tanto o general quanto Franco Frattini, ex-comissário para Justiça, Liberdade e Segurança ${ }^{125}$, afirmaram que a agência serviria não apenas para garantir a segurança interna, mas também para ajudar os países de fronteira a arcar com os altos custos das operações e evitar que tragédias ocorram com indivíduos que tentem cruzar as fronteiras ilegalmente. Ambos apresentam discursos semelhantes sobre como a Frontex serviria para previnir que imigrantes ilegais sejam explorados por "coiotes" ou morram tentando atingir o continente europeu em frágeis embarcações (Laitinen, 2007, 2008; Frattini, 2007).

Percebe-se, portanto, que há um extenso debate na UE acerca das políticas de controle de fronteiras, que envolve os Estados membros, as instituições europeias e a sociedade civil. Este, contudo, precede à criação da Frontex e mesmo aos atentados do dia 11 de setembro de 2001, sendo um tema controvertido desde os anos 1970 e altamente relevante na agenda política desde a assinatura do Acordo de Schengen, em 1985. Assim, cabe analisar o longo processo de convergência entre as políticas de imigração e de segurança interna, a forma pela qual as burocracias europeias influenciaram neste processo e, finalmente, como se produziu um contexto político-institucional no qual foi possível a criação da Frontex.

\subsection{Desenvolvimento das políticas comuns para imigração e segurança}

\footnotetext{
${ }^{125}$ Frattini esteve à frente deste gabinete entre 2004 e 2008. Em 2010 esta pasta foi dividida em duas, tendo sido criados os cargos de comissário para Justiça, Direitos Fundamentais e Cidadania e o comissário de Assuntos Internos.
} 
No final da década de 1940, durante as primeiras reuniões entre líderes europeus sobre o projeto de integração regional, os desafios para reerguer a economia europeia no pós-guerra já figuravam entre os principais tópicos de debate. Esta preocupação marcou a criação da Comunidade Europeia do Carvão e do Aço (CECA), de 1949, e se manteve central na década seguinte, quando os Estados membros (França, Alemanha, Itália e o Benelux) começaram a obter êxito na reconstrução de sua infraestrutura e indústria. Este esforço econômico, no entanto, não teria sido possível sem a mão-de-obra estrangeira convidada a trabalhar nos seis países da CECA.

Ao longo das décadas de 1950 e 1960, enquanto os Tratados de Roma aprofundavam a integração e davam os primeiros passos em direção ao mercado único, houve uma enorme demanda por força de trabalho flexível e de baixo custo, o que não existia no contexto doméstico. Neste período, o fluxo de estrangeiros não era uma questão politicamente sensível e agências de contratação (das quais muitas eram estatais) promoviam a chegada de milhões de imigrantes, principalmente dos países do sul da Europa (Portugal e Espanha), do norte da África e da Turquia. Não eram raros os casos em que, por pressão dos empregadores europeus, imigrantes aceitavam péssimas condições de trabalho e mantinham-se sem a documentação adequada para exercer sua profissão. A maioria dos imigrantes chegou ao continente com contratos temporários, mas muitos nem sequer regularizaram sua estadia, mantendo-se à margem da rede de serviços públicos e seguridade social (Ette \& Faist, 2006). Este cenário se reproduzia em diversos países da Comunidade Europeia sem que fosse visto pelos governos nacionais como um desafio à segurança, pelo contrário: a condição ilegal destes indivíduos contribuía para a exploração de seu trabalho e despertava preocupações relativas às garantias de seus direitos (Geddes, 2000).

A primeira regulação da CEE acerca da mobilidade de extra-comunitários no espaço interno europeu se deu apenas em 1968, quando foi aprovado regulamento 1612 "On freedom of movement for workers within the community". Este mencionava o possível impacto da mão-de-obra estrangeira no mercado interno e, apesar de reafirmar a importância da liberdade de movimento, definia padrões a serem adotados nos diversos países para favorecer o acesso de cidadãos dos Estados membros da Comunidade Europeia aos postos oferecidos. Assim, 
esperava-se criar maior previsibilidade na economia e evitar pressões negativas no mercado de trabalho (Huysmans, 2006). Já havia, portanto, uma distinção clara entre os direitos dos cidadãos europeus e dos imigrantes, porém o impacto destas questões na agenda política dos Estados ainda era bastante limitado.

Esta situação começou a mudar a partir da década de 1970, principalmente depois de 1973, quando a crise do petróleo atingiu diversos setores da economia europeia e forçou muitos cidadãos nacionais a aceitarem os postos e as condições de trabalho antes reservados aos imigrantes. Neste período, a percepção de que os estrangeiros poderiam impactar de forma negativa na economia e onerar pesadamente os Estados começou a crescer, sendo seguida por iniciativas de adoção de uma legislação comum acerca do tema. Aos poucos, a Comunidade Europeia passou a criar normas mais rígidas para o acesso dos imigrantes ao mercado de trabalho e sua inclusão na sociedade.

Indo além, o longo período de recessão econômica (que ficou conhecido como "euroesclerose"), colocou em dúvida o sucesso da integração europeia e transformou definitivamente a realidade dos imigrantes no continente. A impossibilidade de garantir trabalho para os próprios cidadãos levou diversos países não só a cancelar as propostas de emprego a estrangeiros, mas também a revogar vistos de permanência temporária de imigrantes (Papademetriou, 1996). Nesse cenário, em 1974, a Comunidade Europeia apresentou um plano de ação para lidar com os imigrantes ${ }^{126}$, apontando a necessidade de garantir seus direitos, mas também de estabelecer práticas comuns para resolver o desafio de sua inclusão. Neste documento, o Conselho reconhece o impacto da imigração ilegal e considera fundamental:

“[...] strengthen cooperation between Member States in the campaign against illegal immigration of workers who are nationals of third countries and ensure that appropriate sanctions are laid down to repress trafficking and abuses linked with illegal immigration [...]"(Conselho das Comunidades Europeias, 1976).

Revelava-se em nível europeu a necessidade de combater a imigração ilegal, tendo como justificativa: (1) a degradação da situação dos imigrantes que, mantendo-se ilegais, tinham uma condição de vida extremamente frágil, sendo

${ }^{126}$ Este só foi aprovado pelo Conselho em 1976. 
totalmente dependentes de seus empregadores; (2) a incapacidade do mercado de trabalho europeu de absorver um grande fluxo de imigrantes; e (3) a criminalidade decorrente da prática da imigração ilegal, fruto das redes transnacionais que ajudavam os indivíduos a burlar os mecanismos de controle dos Estados e dos próprios estrangeiros, que acabavam se encontrando sem perspectivas de prosperidade na Europa e passavam a enfrentar uma sociedade cada vez mais hostil a sua presença (Melotti, 1997).

Não por acaso, neste mesmo período teve início a cooperação no âmbito do Clube de Berna, no TREVI e no Grupo de Trabalho Policial contra o Terrorismo ( $\mathrm{PWGT}^{127}$ ). O primeiro foi criado em 1971, sem relação direta com as instituições europeias, para servir como um mecanismo de troca de informações confidenciais e consultas entre agências de segurança. Entre outros, participavam inicialmente deste grupo os serviços secretos da Alemanha, França e Reino Unido. Trata-se de uma organização estruturada, que mantém redes perenes de comunicação e lida com questões de crime organizado, terrorismo e subversão. O objetivo principal do Clube de Berna é construir confiança entre os participantes, o que se dá, por exemplo, com a criação de padrões semelhantes para o treinamento de jovens agentes, a coordenação de operações de campo e a produção em conjunto de avaliações sobre ameaças à segurança europeia (Aldrich, 2004). Este grupo recebeu grande atenção em 2001, tendo conduzido operações de inteligência que levaram à prisão de dezoito suspeitos de participação em redes terroristas ligadas a Osama bin Laden mesmo antes dos atentados de 11 de setembro. Após este fato, o clube criou o Grupo de Contraterrorismo, do qual participam países da UE, mas também Estados Unidos, Noruega e Suíça. Desde os anos 1970, o Clube de Berna tem trabalhado no sentido de aumentar a relação entre os serviços de inteligência europeus, apoiando o compartilhamento de dados e a adoção de doutrinas no combate às ameaças comuns (Aldrich, 2004).

Avançando objetivos semelhantes, mas com uma organização e um modus operanti bastante distintos, em 1975 foi criado o TREVI. Conforme visto anteriormente, esta instituição foi a primeira a reunir periodicamente representantes dos Estados para debater sobre questões de segurança interna no

\footnotetext{
${ }^{127}$ Sigla em inglês para Police Working Group on Terrorism.
} 
marco das comunidades europeias. A criação do TREVI partiu da percepção de que, com o aumento da mobilidade na Europa, seria cada vez mais difícil para os países combater a criminalidade e o terrorismo sem uma abordagem integrada para estes problemas. Os ministros de interior, chefes das forças de segurança doméstica e guardas de fronteira viram a necessidade de compartilhar informações sobre o crime organizado e movimentos radicais e criaram grupos de trabalho ad hoc para discutir sobre estas questões. O sucesso do TREVI atraiu o interesse de países que não pertenciam à $\mathrm{CEE}$, mas que viam a possibilidade de ganhos na cooperação com esta instituição. Formou-se assim o grupo "Amigos do TREVI", composto por especialistas em segurança de outros países europeus, mas também dos Estados Unidos e Canadá. Os seis principais temas abordados foram: combate ao terrorismo; treinamento de forças policiais e difusão de conhecimento sobre mecanismos de manutenção da ordem pública (voltado para contenção de revoltas urbanas e hooligans); procedimentos de segurança para viagens aéreas; monitoramento do crime organizado e do tráfico de drogas (que posteriormente motivou a criação da European Drugs Unit); segurança nas instalações nucleares; e medidas de contingência em situações de crise (voltadas para desastres ambientais).

As análises produzidas pelo TREVI foram fundamentais para que em agosto de 1978 entrasse em vigor a Convenção Europeia para a Supressão do Terrorismo. Apesar de não ter sido assinada no âmbito das comunidades europeias $^{128}$, sua amplitude revelou o consenso entre os governos europeus de que a ameaça terrorista estava ligada a outros riscos para a segurança do continente. Mais uma vez, consagrou-se a visão de que o crime organizado, a imigração ilegal e o terrorismo eram diferentes dimensões de um mesmo problema e o combate a este enfrentava barreiras na legislação para extradição (Zimmermann, 2006). Desta forma, além de promover a assitência mútua em assuntos criminais, a convenção teve como foco evitar que exceções da Convenção Europeia para Extradição, especificamente no ponto em que esta protege os indivíduos cuja

\footnotetext{
${ }^{128}$ Tratou-se de uma inicitativa do Conselho da Europa assinada por: Áustria, Bélgica, Chipre, Dinamarca, Alemanha (ocidental), França, Islândia, Itália, Liechtenstein, Luxemburgo, Países Baixos, Noruega, Portugal, Espanha, Suécia, Suíça, Turquia, Reino Unido, Grécia, Irlanda e Malta. Em 1979, no entanto, a CEE deu início ao processo de incorporação desta convenção em seu acervo jurídico.
} 
extradição teria motivações políticas, prejudicassem as investigações das agências de contraterrorismo ${ }^{129}$ (Conselho da Europa, 1978).

Os trabalhos no âmbito do PWGT, por sua vez, tiveram início em 1979, após um atentado contra o embaixador britânico nos Países Baixos ${ }^{130}$. Como resposta a este fato, o governo holandês organizou uma reunião com membros dos corpos especiais das forças policias e os serviços de segurança interna dos doze países da CEE, além de representantes da Finlândia, Noruega, Suécia e Áustria. O PWGT se reúne a cada seis meses, sempre em uma capital europeia, e foi responsável pelo desenvolvimento de um apurado sistema de comunicação, o Facsimile Communication System (FCS). Este foi lançado em 1988, representando uma inovação tecnológica fundamental para a troca de informações confidenciais sobre ameaças ao continente. O FCS serviu também como base para alguns dos sistemas integrados de informação desenvolvidos pela UE nos anos 1990 (Bunyan, 1993).

A criação do Clube de Berna, do TREVI e do PWGT representou um passo fundamental rumo à cooperação em temas de segurança, mas gerou problemas sérios em relação à transparência das ações e à possibilidade de participação da sociedade civil neste campo. Os documentos produzidos pelos grupos de trabalho circulavam apenas entre oficiais dos Estados e agências de inteligência, sendo o controle democrático bastante reduzido (Bunyan, 1993, Aldrich, 2004).

Apesar destas incursões iniciais dos países europeus em assuntos de segurança interna e justiça e da difícil situação econômica em que se encontrava a Europa, um grande número de trabalhadores temporários se recusou a voltar a seus países de origem. Após anos vivendo longe de sua terra natal, muitos já consideravam a Europa como sua casa e, tendo constituído família e laços afetivos, preferiam enfrentar os desafios da crise econômica, os riscos de

\footnotetext{
${ }^{129}$ Tratava-se na época de uma questão fundamental para as forças nacionais de segurança. A demanda, que ganhou forma através do TREVI, era de que o artigo 3(1) da Convenção Europeia de Extradição não tivesse uma interpretação que permitisse aos acusados de atos terroristas e crime organizado alegarem perseguição política em seus países de origem para permanecerem em seus destinos de "fuga". Nesse sentido, em nome da eficiência na investigação criminal, a proteção contra extradição foi bastante reduzida na Europa (Lagodny, 1989).

${ }^{130}$ No dia 22 de março de 1979, Richard Sykes foi morto à tiros por dois homens quando se dirigia à embaixada britânica em Haia. Na época, suspeitou-se de grupos terroristas do Iraque e de alguns movimentos palestinos, mas confirmou-se que o assassinato fora planejado por integrantes do IRA (BBC, 1979).
} 
desemprego, a crescente xenofobia e a possibilidade de expulsão do que tentar reconstruir a vida em outras regiões (Papademetriou, 1996). A Europa se tornara, definitivamente, multicultural e cabia aos governantes estabelecer os padrões pelos quais estes estrangeiros seriam integrados.

O debate sobre o multiculturalismo - presente na sociedade, mas não necessariamente nas políticas governamentais - ganhou espaço nos anos 1980. Enquanto os conflitos ideológicos da Guerra Fria deixavam de pautar a geopolítica europeia e novas questões começavam a influenciar as demandas sociais (sendo a proteção do meio ambiente o principal exemplo deste processo), o tema dos estrangeiros na Europa passou a receber ainda mais atenção. Contudo, na medida em que os bons ventos voltavam a soprar na integração europeia e o mercado único se constituía, os Estados focaram mais nos possíveis desafios gerados pelos imigrantes que em sua contribuição cultural, política e econômica. A cooperação no marco do grupo de TREVI influenciara a produção de estudos sobre o impacto da imigração na criminalidade e, principalmente, sobre a relação de grupos radicais estrangeiros com o risco de atentados terroristas no continente europeu (ver Bunyan, 1993). Desta forma, ao receio sobre os problemas econômicos gerados pelos imigrantes, somou-se a percepção de que estes eram vetores em potencial de ameaças à segurança.

A década de 1980 confirmou a tendência dos anos anteriores, tendo sido palco de transformações significativas no que tange à natureza das políticas aprovadas no âmbito da Comunidade Europeia e também nas próprias dinâmicas da mobilidade global. A integração tornou difícil a distinção entre as medidas nacionais e supranacionais para asilo e imigração, dando ênfase tanto à constituição do mercado interno quanto ao fortalecimento de seus limites geográficos. Neste mesmo período, o fenômeno da imigração se tornou mais rápido, globalizado, plural em suas motivações, consideravelmente feminino (devido impacto da reunião do núcleo familiar) e, finalmente, mais politizado (Geddes, 2000). Foi justamente para se adaptar a estas novas dinâmicas - e seus impactos demográficos, econômicos e políticos -, bem como complementar o mercado único, que o Acordo de Schengen foi assinado.

Este acordo não representa um marco de inflexão nas percepções sobre os imigrantes na Europa, mas certamente ajudou a consolidar uma imagem coletiva que relaciona este grupo a questões amplas de insegurança. A partir de 1985, os 
debates no nível europeu sobre políticas de asilo e imigração passaram a ser definidos segundo três preocupações: a manutenção da ordem pública, os riscos para o Estado de bem-estar social e as implicações para a composição cultural das nações europeias (Bigo, 1994). Desde então, esta é a visão que tem servido como pano de fundo para as políticas dos Estados e da UE no campo de justiça e assuntos internos, sendo a marca das práticas de exclusão que levaram diversos

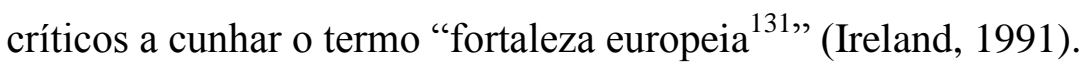

A dicotomia entre mobilidade e controle é bastante clara no texto do Acordo de Schengen, o que reflete o interesse pela consolidação do mercado único em sua forma mais ampla - com a livre circulação de bens e pessoas -, mas também a necessidade de definir e controlar este espaço. Esta inquietação se revela na demanda por cooperação em mecanismos técnicos (como a elaboração do SIS) que podem ser vistos, por exemplo, no artigo 7 do acordo:

\begin{abstract}
"The parties shall endeavour to approximate as soon as possible their visa policies in order to avoid any adverse consequences that may result from the easing of controls at the common frontiers in the field of immigration and security" (Acordo de Schengen, 1985, art. 7).
\end{abstract}

Esta tendência se consolidou nos anos seguintes, de modo que o texto da Convenção para a aplicação do Acordo de Schengen - 1990 Convention Applying the Schengen Agreement of 14th June 1985 - já apresenta de forma clara a convergência entre as políticas de imigração, asilo, terrorismo, crime transnacional e controle de fronteiras (Huysmans, 2000).

Entre a assinatura do Acordo de Schengen e a convenção mencionada, entrou em vigor o Ato Único Europeu (AUE, assinado em 1986, mas ratificado apenas em 1987). Este ato representou a primeira grande revisão dos Tratados de

\footnotetext{
${ }^{131}$ Alguns autores, entre eles Geddes (2000; 2001), rejeitam o termo "fortaleza europeia" e argumentam que mesmo com as políticas de segurança interna, muitas das medidas implementadas pelos países europeus visavam à inclusão de comunidades estrangeiras, bem como a garantia de seus direitos. Além disso, "Europe is not literally a fortress in either the external or internal sense while the EU as an institution does not have the resources to take on this role" (Geddes, 2001, p. 36). Embora concorde que a metáfora da "invasão" de imigrantes tenha desempenhado um papel relevante na construção do imaginário coletivo europeu acerca deste tema (sendo alimentada pelo medo da incapacidade de controlar totalmente as fronteiras), Geddes afirma que na época esta retórica era ainda restrita aos discursos da extrema-direita que, ao apresentar os imigrantes como ameaças à identidade europeia e responsáveis pelo crime organizado no continente, demandava a construção de barreiras mais fortes à entrada de estrangeiros. Esta posição, portanto, seria minoritária no nível regional e incapaz de definir a agenda política.
} 
Roma e o fim do período de "euroesclerose", tendo unificado as comunidades europeias ${ }^{132}$ e apontado uma série de inovações: institucionalizou o Conselho Europeu; estabeleceu mecanismos para coordenação de políticas monetárias; avançou em temas de direitos sociais, ciência e tecnologia, e meio ambiente; reformou e expandiu os fundos estruturais europeus; e principalmente, firmou o compromisso para a criação do mercado único em 1992 (Dinan, 1994). Apesar do progresso mencionado, este ato não foi capaz de estabelecer um consenso acerca da liberdade de movimento no espaço interno, tendo deixado as negociações sobre o fim dos controles de fronteira para um grupo mais reduzido de países. No entanto, ao tratar da criação do mercado único, este documento ratifica as perspectivas acerca dos desafios gerados para a segurança europeia a partir da mobilidade. O texto do AUE define o mercado único como "an area without internal frontiers in which the free movement of goods, persons, services and capital is ensured in accordance with the provisions of this Treaty" (Ato Único Europeu, 1986, art. 13) e determina que este só seria viável caso houvesse uma harmonização e fortalecimento do controle das fronteiras externas (Ato Único Europeu, 1986; Huysmans, 2000).

O passo seguinte para lidar com a questão da imigração foi direcionado à adoção de mecanismos legais que tornariam mais efetivo o controle dos refugiados na Europa. A Convenção de Dublin, de 1990, estabeleceu critérios comuns para a aceitação dos pedidos de asilo e diminuiu o tempo de estadia dos refugiados nos campos de detenção. Sua motivação política, no entanto, era reduzir o número de pedidos e aumentar o controle sobre estrangeiros que se encontravam na situação de requerentes (Huysmans, 2006). Uma vez que os indivíduos eram obrigados a solicitar asilo no país pelo qual tivessem entrado no espaço europeu, esta convenção reduziu as possibilidades de aprovação dos $\operatorname{pedidos}^{133}$.

Observando os mais de vinte anos de desenvolvimento de políticas comuns, é possível afirmar que no momento da assinatura do Tratado de

\footnotetext{
${ }^{132}$ Até então os tratados assinados em Roma previam a coexistência da CECA, da Comunidade Europeia de Energia Atômica (EURATOM) e da Comunidade Econômica Europeia (CEE).

${ }^{133}$ Até 1990 era prática comum na Europa que estrangeiros enviassem solicitações de asilo para diversos países, buscando brechas nas legislações nacionais e aumentando as chances de algum país permitir sua estadia. A Convenção de Dublin visava a coibir esta prática, diminuindo as possibilidades dos estrangeiros de terem uma resposta positiva, mas também sobrecarregando os serviços de imigração dos países de fronteira.
} 
Maastricht a questão da imigração já era uma das prioridades das políticas europeias. Os documentos mencionados e as instituições criadas demonstram atenção à integração dos imigrantes na sociedade e à garantia de seus direitos básicos, mas também o foco na ameaça que estes representam para a segurança. É justamente esse argumento que leva Ireland (1991) a afirmar que a Europa caminhava para a construção de uma fortaleza, na qual o ambiente interno de liberdade e justiça seria cercado pelo crescimento das preocupações com segurança e implementação de mecanismos de controle. Conforme visto, esta mudança de perspectiva não foi marcada por um evento específico que transformou o senso comum em relação ao imigrante, mas foi lenta e gradual, tendo como alguns dos principais atores os agentes de segurança.

A análise deste longo processo evidencia os argumentos de Bourdieu sobre a forma como se dá a construção de conhecimento em determinado campo. A percepção do imigrante como ameaça não foi fruto dos discursos de líderes nacionais, mas sim da cooperação política e profissional na área de segurança interna na Europa. Ou seja, as redes, muitas vezes informais, de agentes de segurança e especialistas em controle de fronteiras foram responsáveis pela disseminação de práticas de exclusão dos imigrantes. No nível europeu, destacaram-se o TREVI, o Clube de Berna e o PWGT, que influenciaram decisivamente as discussões sobre os termos do Acordo de Schengen e a forma como este foi incorporado no Tratado de Maastricht. Partem destas redes os argumentos "técnicos" que advogam pela compreensão conjunta das práticas de combate ao crime organizado/terrorismo e as políticas de imigração. Este discurso tem forte influência na forma pela qual a sociedade passa a conceber o fenômeno da imigração e nas estratégias adotadas pelos governos para lidar com o tema.

Segundo Huysmans, "For the Police it is part of their profession to produce security knowledge. They have a professional disposition to represent and categorize a policy concern in a security discourse and to propose security measures to deal with it" (Huysmans, 2000, p. 757). O resultado da incorporação destes atores no debate sobre imigração é a transformação das premissas do próprio debate, que perde a ênfase nos direitos humanos e na busca por inclusão e passa a apontar soluções para um problema de segurança. Indo além, o autor afirma que: 
"Their [dos agentes] knowledge has a capacity to define security questions. The police are security professionals who are trained to identify and deal with challenges to public order and the rule of law. Their professional status thus gives them the power to identify dangers to social fabric" (Huysmans, 2000, $\mathrm{p}$. 761).

Assim, não apenas os agentes incorporam a questão da imigração no seu escopo, como seu poder simbólico no campo da segurança faz com que estes ainda produzam estudos vistos como mais adequados para lidar com os imigrantes.

Por fim, através desta abordagem, percebe-se que a imigração se tornou um tema de segurança não apenas por causa do terrorismo, mas também pelo suposto risco ao mercado interno. Não é coincidência o fato de a crise dos anos 1970 e os debates sobre a criação do mercado único nos 1980 terem impulsionado uma visão contrária à imigração. Segundo os argumentos "técnicos" apresentados, sem os controles internos de fronteira, e dada liberdade de fluxo de capitais e serviços, a imigração poderia representar um problema para a ordem pública e o Estado de direito.

\subsection{A criação da UE e os novos mecanismos europeus para o controle de imigração}

No início dos anos 1990, com a queda dos regimes socialistas, o continente europeu passou por sérias transformações. Além das negociações para a unificação da Alemanha, entrou na pauta da integração europeia o alargamento para o leste, que abrangeria países com pouca experiência democrática e nenhuma vivência na economia de mercado. Foi neste contexto que no dia 7 de fevereiro de 1992 líderes de doze países assinaram o Tratado de Maastricht. Este trouxe inúmeras inovações, que foram divididas em três grupos (ou pilares) devido ao grau de subsidiariedade: as Políticas Comunitárias, Política Externa e de Segurança Comum (PESC), e Justiça e Assuntos Internos.

Acordou-se que os temas relativos às políticas de imigração e controle de fronteiras teriam maior coordenação, mas seriam mantidos na esfera intergovernamental, ou seja, qualquer modificação na legislação da UE só poderia 
ocorrer com a anuência de todos os países membros. Além disso, o Acordo de Schengen foi incluído no rol de políticas do terceiro pilar, o que tornou obrigatória a adesão ao espaço comum para todos os países que participassem das rodadas de alargamento, mas não para os que já pertenciam à UE.

Sob este mesmo pilar foram alocadas as agências de segurança interna. A ideia de um corpo policial europeu era antiga e tinha como principal patrocinador o TREVI, que demandava uma instituição semelhante ao FBI para auxiliar no combate ao crime transfronteiriço e ao terrorismo ${ }^{134}$ (Europol, 2012; Occhipinti, 2003). O Tratado de Maastricht, em seu artigo K1(9), abriu espaço para que a Europol fosse criada:

"For the purposes of achieving the objectives of the Union, in particular the free movement of persons, and without prejudice to the powers of the European Community, Member States shall regard the following areas as matters of common interest: [...] 9. police cooperation for the purposes of preventing and combating terrorism, unlawful drug trafficking and other serious forms of international crime, including if necessary certain aspects of customs cooperation, in connection with the organization of a Union-wide system for exchanging information within a European Police Office (Europol)" (Tratado de Maastricht, 1992, K1).

É importante notar que o artigo abordando as políticas de asilo e imigração é o mesmo que apresenta dispositivos legais para coibir a ação de terroristas, confirmando que estas questões seriam, a partir de então, formalmente vistas segundo uma mesma lógica, a da segurança interna. Por mais que os trabalhos da Europol (e da Eurojust) só tenham iniciado após as negociações sobre emendas ao Tratado de Maastricht, em 1992 já estava claro que os mecanismos de controle de fronteira operavam para coibir a imigração ilegal e o terrorismo, percebendo ambos como ameaças ao espaço interno europeu.

\footnotetext{
${ }^{134}$ Este é o argumento apresentado pela própria instituição. Segundo a Europol, "Trevi's initial concern was to address international terrorism, but it soon extended its focus of attention to cover other areas of cross-border crime within the European Community. In the 1970s and 1980s, there were frequent calls from within and outside the Trevi group to formalise police cooperation within the Community [...] In 1991, at the European Summit in Luxembourg, the German chancellor called for a European police agency to be set up along the lines of the American FBI." (Europol, 2012).
} 
Outra inovação relevante deste período foi a criação do High Level Working Group on Asylum and Migration (HLWG), que tinha como objetivo gerar uma convergência entre a política externa europeia e as demandas por segurança interna. Este grupo promoveu o debate sobre o impacto da imigração na sociedade e se tornou um espaço de produção de propostas sobre como as relações da UE com seus vizinhos poderiam ser moldadas no sentido de favorecer as políticas de controle de fronteiras e o combate à imigração ilegal. Ao longo dos anos, diversos planos de ação foram apresentados contendo, basicamente, três propostas: (1) a adoção por parte de países extra-comunitários de políticas de monitoramento de fronteira e dos fluxos de imigrantes, sendo fundamental o apoio das instituições europeias na construção de know-how nesta área; (2) cooperação da UE para desenvolvimento econômico-social das regiões de fronteira, o que diminuiria a pressão migratória; e (3) ratificação de acordos de readmissão, que facilitaria os trâmites jurídicos para a expulsão dos indivíduos presos devido à situação ilegal (Van Selm, 2002). Com a notória exceção deste último ponto ${ }^{135}$, o HLWG obteve sucesso no estabelecimento de canais de diálogo com países fronteiriços, levando, por exemplo, à inclusão de suas demandas na Parceria EuroMediterrânea e nos documentos da Política Europeia de Vizinhança ${ }^{136}$, que definem as relações da UE como muitos dos países do norte da África e do Oriente Médio ${ }^{137}$ (Geddes, 2000).

Em 1997, o Tratado de Amsterdã decidiu pela incorporação do Acordo de Schengen ao acquis communautaire da UE (pilar comunitário). Quando este tratado entrou em vigor, três anos depois, o Conselho demandou a publicação do Schengen Acquis ${ }^{138}$ no Diário Oficial da União, reforçando que uma

\footnotetext{
${ }^{135}$ Estes acordos geraram controvérsias políticas e alguns países decidiram não cooperar para a readmissão de imigrantes ilegais, entre eles a Turquia. Para mais, ver Van Selm (2002).

${ }^{136}$ A Declaração de Barcelona, de 1995, e a Política Europeia de Vizinhança, de 2004, foram duas das iniciativas mais relevantes de aproximação da UE com os países fronteiriços. Ambas visavam a promover paz, prosperidade e segurança na região do Mediterrâneo e no Oriente Médio. Para mais, ver Biscop (2004) e Emerson et al (2005).

${ }^{137}$ Desde a assinatura do Tratado de Amsterdã a cooperação internacional visando questões internas cresceu enormemente, ganhando um espaço significativo na agenda externa da UE. Durante as reuniões no Conselho de Tampere este tema foi bastante relevante, levando os chefes de estado a afirmarem que "[...] all competencies and instruments at the disposal of the Union, and in particular in external relations, must be used in an integrated and consistent way to build the area of freedom, security and justice. Justice and Home Affairs concerns must be integrated in the definition and implementation of other union policies and activities" (Conselho de Tampere, 1999, ponto 59).

${ }^{138}$ Ver Diário Oficial, dia 10 de julho de 1999, p. 1.
} 
"[...] ever closer union of the peoples of the Member States of the European Communities should find its expression in the freedom to cross internal borders for all nationals of the Member States and in the free movement of goods and services" (Conselho Europeu, 2000, p. 13).

No entanto, com este ato, o Conselho estava também "taking into account the importance that the Contracting Parties attach to effectively combating terrorism within their common territory" (Conselho Europeu, 2000, p. 435).

Ao alocar os dispositivos de Schengen junto às políticas comunitárias, a UE deu um passo definitivo rumo ao fim das fronteiras internas, mas reforçou os limites externos da comunidade, o que gerou o spill-over do projeto econômicosocial de integração para um projeto de segurança. Esse spill-over foi possível graças à identificação de um efeito colateral na criação do mercado interno: a previsão de que a liberdade de movimento facilitaria atividades ilegais e violentas por parte de terroristas, do crime organizado e de imigrantes (Huysmans, 2000).

Observando as transformações promovidas em Amsterdã, Guiraudon e Lahav (1999) afirmam ainda que houve uma grande preocupação em meio aos agentes de segurança domésticos com a maior eficiência no controle de fronteiras, de modo que já seria possível apontar para tendências de privatização desta prática. Através da terceirização, esperava-se que as barreiras fossem menos físicas, privilegiando mecanismos inteligentes, capazes de identificar os indivíduos suspeitos e fazer a triagem sem que esta fosse aparente aos cidadãos. Já nesta época debatia-se sobre novas tecnologias de vigilância, o uso da biometria em passaportes e vistos, e, principalmente, sobre o uso de bases de dados interligadas, capazes de facilitar a troca de informações entre agentes de segurança nacionais e destes com as instituições europeias (Guiraudon \& Lahav, 1999).

As conclusões da Cúpula de Tampere, de outubro de 1999, reafirmaram as demandas vistas em Amsterdã e criaram a "área de liberdade, segurança e justiça”. Passados sete anos da formulação do mercado único e próximos da finalização da união monetária, os chefes de estado reunidos na cidade finlandesa constataram que: 
"the European Union should not only be a single market and an economic and monetary union but also an 'area' of freedom, security and justice - an area where everyone can enjoy his or her freedoms, can live and work where he/she wishes in safety, and where disagreements and disputes can be sorted out fairly and justly" (Conselho Europeu, 1999).

As conclusões desta cúpula apontam especificamente para impossibilidade de dissociar os debates sobre a liberdade de movimento no espaço interno dos avanços na cooperação entre forças de segurança e na articulação entre os corpos jurídicos e as legislações nacionais. Assim, este conselho apresentou quatro pontos centrais para o aprimoramento do pilar de Justiça e Assuntos Internos: uma política comum de asilo e imigração; uma área genuína de justiça; práticas que englobem toda a União no combate ao crime; e uma ação externa mais forte. Em Tampere também foi dado o passo decisivo para a definição do escopo de operações da Europol, que seria central na coordenação dos atores nacionais responsáveis por evitar a criminalidade e atentados terroristas. Conforme consta no documento final,

"[A] Maximum benefit should be derived from co-operation between Member States' authorities when investigating cross-border crime in any Member State. The European Council calls for joint investigative teams as foreseen in the Treaty to be set up without delay, as a first step, to combat trafficking in drugs and human beings as well as terrorism. The rules to be set up in this respect should allow representatives of Europol to participate, as appropriate, in such teams in a support capacity". (Conselho da União Europeia 1999, B.IX, par. 43).

Este mesmo documento traz ainda as bases sobre as quais se constituiria a cooperação para o controle das fronteiras comuns. Ao tratar do gerenciamento dos fluxos migratórios, o Conselho declara que:

"The European Council calls for closer co-operation and mutual technical assistance between the Member States' border control services, such as exchange programmes and technology transfer, especially on maritime borders, and for the rapid inclusion of the applicant States in this co-operation" (Conselho da União Europeia, 1999, A.IV, par. 24). 
A semelhança desta demanda com os pontos elencados na resolução (EC) No. 2007/2004, que criou a Frontex, é bastante representativa, apontando para os mesmos desafios e para as mesmas soluções no que tange o monitoramento da mobilidade no espaço interno.

\title{
4.3. As respostas europeias ao terrorismo: ausência do processo de securitização
}

A cúpula de Laeken, em dezembro de 2001, foi central para o debate acerca das políticas europeias nos anos seguintes. Ela teve lugar cerca de três meses após os ataques terroristas nos Estados Unidos e expressou preocupação com esta modalidade de violência. Em sua resolução final, o Conselho declarou que:

\begin{abstract}
"[...] the eleventh of September has brought a rude awakening. The opposing forces have not gone away: religious fanaticism, ethnic nationalism, racism and terrorism are on the increase, and regional conflicts, poverty and underdevelopment still provide a constant seedbed for them." (Conselho
\end{abstract} Europeu, 2001, p. 20).

Nesse sentido, a UE necessitaria de um "better management of the Union's external border controls, [as it] will help in the fight against terrorism, illegal immigration networks and the traffic in human beings. (Conselho Europeu, 2001, p. 12).

Apesar de o terrorismo ser compreendido como um grave perigo, a resolução da primeira reunião ordinária do Conselho após os atentados lida com esta questão como uma dentre toda a série de ameaças enfrentadas pela UE. Além disso, as conclusões de Laeken não falam sobre emergência, urgência ou exceção, mas propõem uma melhor fórmula para o gerenciamento das fronteiras. No capítulo específico sobre as respostas aos atentados, o Conselho menciona um caráter de urgência apenas para ressaltar a necessidade de ajuda humanitária ao Afeganistão e explicar as razões que levaram a UE a criar um fundo de doações a este país. No que tange às políticas para o controle de fronteiras, clama-se pelo 
estabelecimento de arranjos comunitários e pela elaboração de estudos sobre a viabilidade de um serviço comum de guardas. Contrariando a literatura sobre securitização, estas inovações são colocadas como formas de pôr em prática políticas delineadas pelo Tratado de Maastricht e endossadas em Tampere, não como respostas emergenciais à ameaça terrorista.

Analisando este documento percebe-se ainda que, de uma forma geral, o Conselho Europeu estava mais preocupado com as dificuldades advindas da adoção do Euro e as perspectivas para a qualidade de vida na União do que com políticas especiais de segurança ${ }^{139}$. As conclusões de Laeken apontam para cinco grandes temas: o futuro institucional da UE; as ações subsequentes aos atentados; as tendências para o desenvolvimento sustentável; o fortalecimento da área de liberdade, segurança e justiça; e relações exteriores; mas todos tocam, em maior ou menor grau, nos desafios provenientes da moeda única e do alargamento. Por fim, a Declaração de Laeken sobre o futuro da UE afirma que a União estaria passando por um período de decisões muito importantes, não por causa das ameaças terroristas, mas sim pois,

"[...] the Union stands at a crossroads, a defining moment in its existence. The unification of Europe is near. The Union is about to expand to bring in more than ten new Member States, predominantly Central and Eastern European, thereby finally closing one of the darkest chapters in European history: the Second World War and the ensuing artificial division of Europe. At long last, Europe is on its way to becoming one big family, without bloodshed, a real transformation clearly calling for a different approach from fifty years ago, when six countries first took the lead" (Conselho Europeu, 2001, p. 20).

Observando os últimos meses de 2001, Neal (2009) argumenta que não há um momento de exceção no pós-11 de setembro. O que se segue aos atentados são negociações sobre melhores mecanismos de controle de fronteiras, divisão de responsabilidades e acomodação de interesses. Nesse sentido, mesmo tendo ocorrido em um período de incertezas, o Conselho de Laeken não viu surgir propostas em termos de políticas emergenciais de segurança. Os representantes dos países da UE preferiam não se comprometer com práticas assertivas neste

\footnotetext{
${ }^{139}$ Evidência disso é que dos 61 pontos debatidos no documento, apenas 3 se referem aos desafios impostos pelo terrorismo internacional.
} 
campo. Deste modo, o que se constatou foi a importância do conceito de gerenciamento integrado de fronteiras, conforme previsto em documentos anteriores da Comissão e em resoluções do Conselho.

Confirmando esta visão, em junho de 2002, ao abordar a questão da imigração em discurso no Parlamento Europeu, o então presidente da Comissão Europeia, Romano Prodi, demandou abertamente, pela primeira vez, a criação de uma agência que lidasse especificamente com questões de fronteira e constatou que:

"[...] the most burning issue to be dealt with by the European Council is immigration. [...] in the eyes of most of our citizens, immigration is becoming increasingly linked with the issue of their protection in the area of freedom, security and justice we are trying to build" (Prodi apud Bertozzi, 2008a, p. 10).

Apesar de apontar a imigração como o principal desafio da UE, Prodi não clamou por poderes especiais para as forças nacionais de segurança, ou pela criação de um mecanismo supranacional - acima dos constrangimentos domésticos - capaz de fechar rotas de imigração e evitar ataques terroristas. O que o presidente da Comissão pediu foi a coordenação de políticas conforme previsto em estudos da Europol e nos tratados de Amsterdã e Nice (Bertozzi, 2008a). Segundo Prodi, era fundamental que houvesse maior troca de informações (dados e boas práticas) entre os oficiais de fronteira, o que ocorreria mais facilmente caso fosse criada uma agência responsável por estas questões. Desta forma, não havia uma demanda por prerrogativas emergenciais e não foi mencionada uma ameaça existencial que necessitaria de medidas de exceção. Pelo contrário, o que Prodi defendeu foi a aplicação de recomendações anteriores da Comissão ${ }^{140}$ (Bertozzi, 2008a).

Nos meses seguintes, a Comissão Europeia preparou dois documentos, nos quais foram colocadas algumas propostas para a cooperação entre os Estados e a criação de órgãos europeus para facilitar a integração das políticas europeias. A partir da comunicação "Toward Integrated Management of the External Borders

\footnotetext{
${ }^{140}$ Apenas no segundo semestre de 2003, sob a presidência grega, a UE voltou a trabalhar sistematicamente em busca da criação de uma instituição regional capaz de fortalecer o controle das fronteiras comuns. É deste período a primeira menção oficial à Frontex (Minutas do $1634^{\circ}$ Encontro da Comissão, 2003, 1634).
} 
of the Member States of the European Union", mencionada na introdução, a comissão listava as práticas a serem adotadas e demandava um avanço por parte dos Estados. Baseado neste documento, o Conselho da UE formulou o plano de ação que levou à criação da SCIFA+ e dos centros operacionais. Já a comunicação "On the Development of a Common Policy on Illegal Immigration, Smuggling and Trafficking of Human Beings, External Borders and the return of Illegal Residents", trouxe uma avaliação das medidas adotadas até então e apontou falhas no sistema vigente de vistos e de monitoramento das fronteiras. Estes documentos, mais uma vez, confirmam a importância do conceito de $\operatorname{IBM}^{141} \mathrm{e}$ afirmam que as respostas ideais para o desafio do terrorismo e da imigração ilegal giram em torno de cinco pontos (bastante próximos ao que se tornaria a jurisdição da Frontex):

"(a) A common corpus of legislation; (b) A common co-ordination and operational co-operation mechanism; (c) Common integrated risk analysis; (d) Staff trained in the European dimension and inter-operational equipment; $(e)$ Burden-sharing between Member States in the run-up to a European Corps of Border Guards" (Comissão Europeia, 2003).

O esboço da regulamentação da Frontex, apresentado no dia 11 de novembro de 2003 pela Comissão, inovou ao propor o desenvolvimento a longo prazo de um corpo de guardas de fronteira da UE. No entanto, o texto deste documento trata, em grande medida, da adoção de uma base legal única para o funcionamento de diversos dispositivos operacionais que já trabalhavam de forma ad hoc. Conforme visto anteriormente, a Frontex foi criada para ocupar o espaço das diversas "unidades comuns" existentes no marco da SCIFA+. A partir do estabelecimento desta agência, o serviço dos centros operacionais (que forneciam

\footnotetext{
${ }^{141}$ É importante notar que, apesar de diversos as instituições europeias mencionarem em inúmeras ocasiões o conceito de IBM, este só foi claramente definido pela UE em 2009. O documento " $E U$ Schengen Catalogue on External borders control, Return and readmission", do grupo de avaliação do Acordo de Schengen, afirma que o "gerenciamento integrado de fronteiras" compreende: "( 1 ) border control, which includes border checks, border surveillance and relevant risk analysis and crime intelligence; (2) the detection and investigation of cross-border crime; (3) the "four-tier access control model" (which includes activities in third countries, cooperation with neighbouring third countries, controls at the external border sites, and inland border control activities inside the Schengen area); (4) inter-agency cooperation for border management and international cooperation; and (5) coordination and coherence of the activities of the Member States and institutions, as well as other bodies of the Community and the Union" (Conselho Europeu, 2009, p. 7).
} 
apoio ao controle das fronteiras terrestres, marítimas e dos aeroportos, além de ajudar no planejamento de operações conjuntas) e do centro de análise de riscos recairiam sob a responsabilidade de um único órgão.

A proposta da Comissão afirma que o trabalho da Frontex seria direcionado para o controle de fronteiras, mas também para a garantia da segurança dos próprios imigrantes que tentassem cruzar ilegalmente as fronteiras comuns. Assim, além de apoiar as operações para a captura de grupos que tentassem acessar o Espaço Schengen sem permissão (por terra ou mar) e estabelecer mecanismos eficientes para a identificação dos indivíduos presos, a agência teria a incumbência de organizar centros de retenção, nos quais os estrangeiros teriam sua situação jurídica analisada e ações pretéritas investigadas. Por fim, também caberia à Frontex proceder com a deportação dos imigrantes não-documentados (Conselho Europeu, 2003).

O procedimento padrão previsto pela Comissão seria que a Frontex apoiasse na interceptação de grupos que tentassem cruzar as fronteiras, facilitando sua triagem e deportação. No caso das operações no mar, esperava-se ainda que as embarcações investigadas pudessem ser enviadas de volta aos portos de origem sem que os indivíduos tivessem direito a solicitar asilo ${ }^{142}$. Nesta proposta, a Comissão tem o cuidado de demonstrar que o estabelecimento da Frontex, especificamente a atuação nas operações marítimas - sua face mais controversa -, não alteraria em nada o marco jurídico vigente, sendo esta cumpridora não apenas das normas europeias, mas também dos principais tratados internacionais.

O atentado do dia 11 de março de 2004 nos trens de Madri fez com que a ameaça terrorista uma vez mais saltasse aos olhos dos líderes europeus. No entanto, apesar de ter sido realçado pela mídia o fato de muitos dos indivíduos que planejaram este ato serem marroquinos (Lahav, 2007), as repostas a este evento também revelam a ausência da retórica da securitização. Ao invés de clamarem

\footnotetext{
${ }^{142}$ Antecipando-se a possíveis críticas a respeito da atuação da Frontex no litoral europeu, a proposta da Comissão afirmou que esta agência seguiria as normas estabelecidas em tratados internacionais sobre a mobilidade no mar. De acordo com esta proposta, a Convenção de Montego Bay traria uma brecha para que guardas de fronteira pudessem controlar embarcações com imigrantes ilegais, sendo permitida a inspeção caso uma embarcação não apresentasse uma nacionalidade ou caso a nacionalidade apresentada fosse posta em dúvida. Além disso, a Comissão interpreta que acordos bilaterais e a Convenção da ONU para o Crime Organizado Transnacional revelam um consentimento para que as autoridades europeias supervisionem o tráfego de navios, evitando a entrada ilegal de indivíduos (Hayes, 2003).
} 
por mais poderes para combater os grupos terroristas instalados no continente, as autoridades europeias fizeram um balanço com uma série de medidas já implementadas que poderiam ter evitado os atentados. Esta avaliação consta no documento European Commission Action Paper in response to the terrorist attacks in Madrid, do dia 18 de março, no qual as autoridades europeias não argumentam em prol da criação de uma agência nos moldes da Frontex, mas sim pelo melhor funcionamento dos órgãos de vigilância e, fundamentalmente, pela maior eficiência na cooperação das autoridades nacionais com a Europol e a Eurojust. Este documento é uma crítica aos Estados membros que ainda limitavam o compartilhamento de informações nos sistemas integrados. Há a constatação de que o melhor meio para a contenção da ameaça terrorista é o diálogo entre as forças de segurança interna, mas a Comissão é bastante clara ao desmotivar a proliferação de mecanismos frágeis de cooperação e focar no fortalecimento das ferramentas já existentes:

\begin{abstract}
"Terrorism is first and foremost an internal security matter and therefore the mechanism we suggest to establish should exchange information mostly within a third pillar umbrella. In this way, we put existing [...] networks in dialogue among themselves rather than losing time destroying existing and creating new procedurally time-consuming institutions and bodies" (Comissão Europeia, 2004).
\end{abstract}

Nos comunicados da Comissão após os atentados em Madri não há menção aos imigrantes e não há exigência de medidas mais restritivas para a entrada de estrangeiros, apenas uma demanda por mecanismos mais eficientes de identificação, como a utilização da biometria nos passaportes e vistos. Nas palavras da Comissão, "We cannot go on producing networks and institutions and then refuse to provide them with the necessary tools to perform their jobs or simply not use them. Much has been done. Let us use it" (Comissão Europeia, 2004). Além disso, não há nenhum argumento sobre urgência ou excepcionalidade, mas sim sobre a eficiência dos mecanismos existentes. Nota-se, portanto, que a resposta europeia ao terrorismo, mesmo quando esse se deu no próprio continente, não tem uma retórica de securitização, mas sim de melhorias técnicas e mais cooperação. 
O estudo destes documentos comprova que as mesmas ideias sobre "cooperação entre agências de segurança" e "gerenciamento integrado de fronteiras", centrais para toda a estratégia europeia frente ao terrorismo e, logicamente, para a gênese da Frontex, estavam explícitas nas políticas da União desde os debates em Amsterdã. Em uma análise mais ampla, é possível afirmar que a UE tem dado sinais sobre a interface entre imigração e ameaças à segurança desde o Acordo de Schengen, o que vai de encontro às hipóteses baseadas na teoria da securitização - de que os eventos de 11 de setembro motivaram uma nova articulação de significados e que as respostas foram radicalmente distintas e excepcionais -, demonstrando que estas não encontram evidências em uma pesquisa empírica mais aprofundada.

\subsection{Contribuições quali-quantitativas para o debate sobre a criação da Frontex}

Seguindo as recomendações metodológicas de Bourdieu, Bigo (1994, 2010b) faz largo uso de ferramentas quali-quantitativas em seus estudos sobre as redes de agentes de segurança na Europa. Estas ferramentas são fundamentais para o mapeamento do campo e, como será visto adiante, para uma análise abrangente sobre as práticas europeias no que concerne o controle da mobilidade nas fronteiras e no espaço interno. Parte da crítica avançada sobre as abordagens da Escola de Copenhague para a criação da Frontex recai nas limitações do escopo analítico apresentado por esta literatura, que ignora o desenvolvimento de conceitos centrais para a atuação desta agência simplesmente por reduzir sua pesquisa à conjuntura do pós-atentado de setembro de 2001 (Huysmans, 2006; Boswell, 2007; Bigo, 2009; Neal, 2009; Léonard, 2011). No entanto, além destas críticas - já apresentadas ao longo do capítulo - constata-se que, mesmo depois dos atentados, as práticas e discursos dos atores europeus não guardavam semelhança com a retórica da securitização. Através do projeto ANTA, uma ferramenta quali-quantitativa, é possível comprovar esta afirmação.

O projeto ANTA ${ }^{143}$ - Actor Network Analyzer - é um software desenvolvido pelo Médialab ${ }^{144}$, da Sciences Po, que tem como objetivo oferecer

\footnotetext{
${ }^{143}$ Para uma descrição pormenorizada sobre esta ferramenta, ver: https://github.com/medialab/ANTA\#readme
} 
aos pesquisadores uma ferramenta capaz de mapear os atores dentro de determinado campo social. Este projeto foi pensado inicialmente como uma contribuição para os trabalhos sobre controvérsias, desenvolvidos por Bruno Latour $^{145}$, mas se expandiu, compreendendo, dentre outras, as pesquisas de Bigo sobre o campo de segurança. Valendo-se do ANTA, Bigo e sua equipe reuniram os documentos produzidos acerca das políticas de controle de fronteiras na UE (comunicados, tratados, resoluções, memorandos e outros) até março de 2010, gerando um amplo banco de dados que pode (1) demonstrar a incidência de determinadas terminologias ao longo do tempo e (2) constituir um mapa que apresente os atores deste campo de acordo com sua relevância ${ }^{146}$ (Venturini, 2010).

O ANTA permite o acesso a mais de 300 documentos produzidos entre 2001 e 2010, identificando-os a partir de terminologias específicas. Os gráficos formulados ajudam na compreensão exata do conteúdo dos documentos, podendo dividi-los, basicamente, em três formatos. Há aqueles que (1) se referem a procedimentos legislativos para o estabelecimento da agência, que delineiam a forma que a Frontex teria e sua capacidade de atuação. Além disso, há uma série de documentos formulados após a criação da Frontex e que (2) apresentam as novas competências que esta acumulou e o impacto do trabalho da própria agência na forma como os membros da Comissão e do Conselho pensam as práticas de controle de fronteiras. Por fim, há documentos que (3) tratam de outras instituições com foco em segurança e/ou imigração na UE, o que permite mapear os atores envolvidos na disputa por construção de conhecimento e produção de políticas de segurança na Europa. Este último grupo, especialmente, ajuda a perceber o impacto da criação da Frontex nas disputas internas pela definiçãa de estratégias (o que será abordado no próximo capítulo).

Através das figuras retiradas do ANTA será possível visualizar como determinadas terminologias são empregadas nos documentos europeus, demonstrando se há ou não a coincidência de discursos de exceção com os argumentos favoráveis à cooperação nos mecanismos de controle de fronteiras.

\footnotetext{
${ }^{144} \mathrm{http}: / /$ medialab.sciences-po.fr/

${ }^{145}$ Para mais sobre esta pesquisa, ver Venturini (2010).

${ }^{146}$ Lamentavelmente, esta segunda ferramenta do programa não pode ser utilizada sem desfrutar do conhecimento técnico do próprio MédiaLab, ou seja, não será possível aproveitá-la nesta dissertação. Contudo, exemplos de mapas são apresentados por Venturini (2010) e Venturini e Latour (2010).
} 
Desta forma, não há uma busca por negar a existência de atos de fala em prol de mecanismos radicais no combate ao terrorismo, mas sim uma investigação sobre as terminologias empregadas no diálogo interno das agências europeias e seus especialistas em segurança. Os documentos não são analisados como discursos para convencer a sociedade, mas sim como um indicativo da forma pela qual os formuladores de políticas pensam as instituições criadas.

O gráfico 4, comparando a incidência das terminologias exception ${ }^{147}$, surveillance e immigration, já aponta para o fato de a correlação entre imigração e exceção ser praticamente nula, mesmo imediatamente após os atentados terroristas. Nesse sentido, a relação entre terrorismo e imigração presente em muitos documentos, parece ser respondida por medidas que seguem os meandros da rotina burocrática da UE. Isto se torna claro quando a relação entre vigilância uma prática do dia-a-dia - e imigração é levada em consideração. O número de documentos que trabalham com ambas as terminologias é bastante representativo, fornecendo mais uma evidência de que a estratégia da União contra as ameaças não é composta de grandes viradas ou decisões marcantes, mas de uma cooperação institucional em "pequenas práticas".

Gráfico 4: Análise comparativa das referências a exception, immigration e surveillance ${ }^{148}$

\footnotetext{
${ }^{147}$ Durante a pesquisa com esta ferramenta, o termo "exception" foi substituído por vários outros de conotação semelhante e que pudessem representar a relação de discursos sobre ameaças emergências e as práticas de vigilância. No entanto, o termo mais recorrente e, portanto, o que melhor representaria esta relação é o que foi aqui utilizado.

${ }^{148}$ Cada ponto nesta figura representa um documento e cada linha uma terminologia. A posição dos pontos interfere, logicamente, na construção das linhas, sendo estas mais altas quando houver maior incidência de determinada terminologia no documento e mais baixas no caso inverso. Neste caso, a linha azul clara (que representa exception) é claramente menos relevante que a linha verde clara (surveillance). Além disso, a concomitância de documentos que trabalham com o tema da imigração e mencionam a necessidade de vigilância é muito maior que a incidência de documentos que abordem imigração e exceção. De fato, por seu tamanho reduzido, este gráfico não permite uma visualização perfeita, mas há 36 documentos abordando a questão da vigilância (muitos com foco exclusivo nesta ferramenta de controle) e apenas 14 que tratam de exceção (sendo que todos abordam esta questão apenas marginalmente).
} 


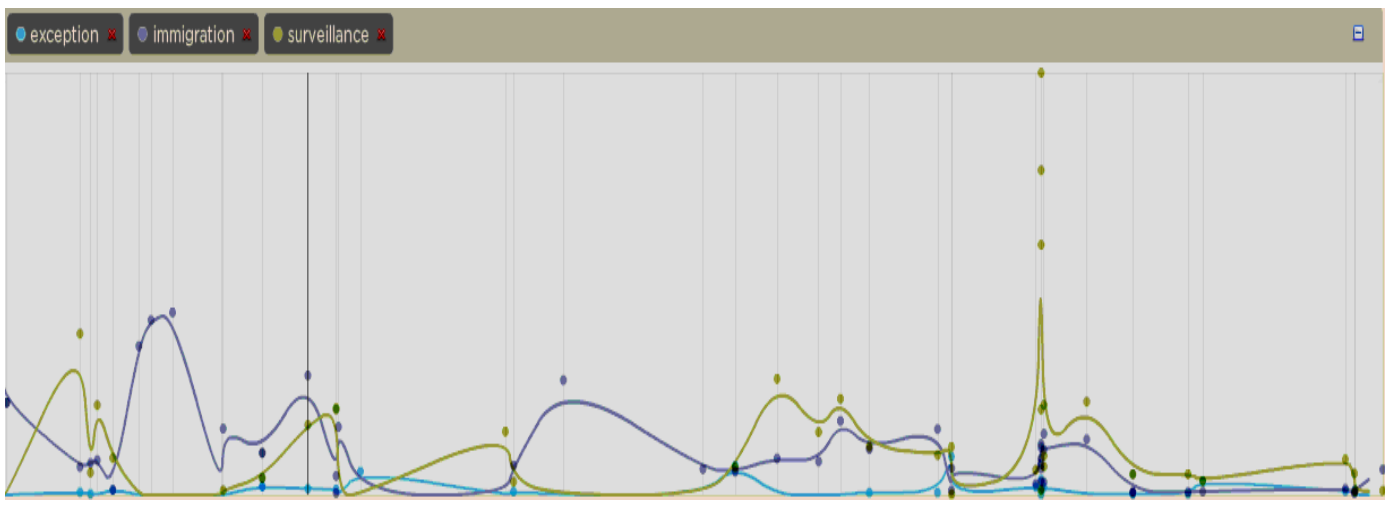

Este argumento também fica claro no próximo gráfico, que traça a correlação entre emergency, urgency e border management ${ }^{149}$. Ao longo do período analisado, a incidência do último termo é muito mais relevante que a dos demais, reforçando a hipótese de que, ao menos no nível europeu, a resposta estabelecida para as ameaças não eram marcadamente novas, nem demandavam decisões que fugissem aos parâmetros políticos vigentes. De fato, é revelador que entre os atentados terroristas e o dia 11 de junho de 2003, quase dois anos, apenas três documentos com referências aos primeiros termos foram produzidos, enquanto, no mesmo período, onze documentos mencionam os termos border management.

Gráfico 5: Análise comparativa das referências a emergency, urgency e border management

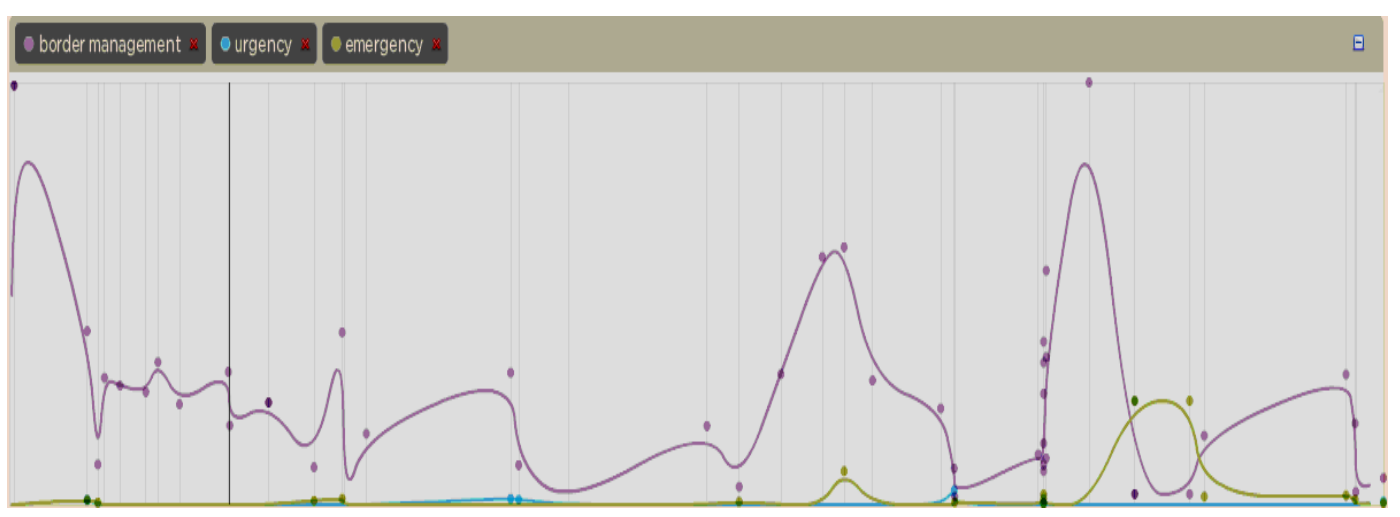

Imediatamente após 11 de setembro, a UE realizou encontros extraordinários de diferentes níveis para lidar com a o tema do terrorismo. No

\footnotetext{
${ }^{149}$ Termo buscado por ser o que melhor revela entre os documentos a presença de discussões sobre o conceito de IBM.
} 
entanto, o primeiro documento que delineia as medidas comuns (não apenas princípios e ideias) sobre esta questão é o "Council Framework Decision on Combating Terrorism", elaborado em junho de 2002. Este documento não estabelece uma definição fechada do tema ${ }^{150}$, mas define algumas iniciativas que deveriam ser tomadas pelos Estados membros. Segundo esta decisão, a UE só estaria segura caso os governos trabalhassem juntos para desestruturar os grupos transnacionais que operam no território europeu (Conselho Europeu, 2002).

Explorando as figuras do ANTA é possível perceber que, após os primeiros meses de intensa discussão sobre o desenvolvimento de mecanismos comuns de vigilância e controle, a questão da "tecnologia", um elemento central para o aprimoramento desta prática, tornou-se mais relevante entre os documentos. A proposta do Reino Unido para a criação do "Centre of Excellence on Mobile Detection Unit ${ }^{151}$ " demonstra que os Estados estavam dispostos a enfrentar as ameaças identificadas por meio de financiamento a novas técnicas de vigilância, como câmeras, scanners e uma variedade de detectores. Somente nos dois primeiros anos após os ataques terroristas, constam doze documentos mencionando de forma conjunta border management, surveillance, detection e technology, todos elaborados por grupos de especialistas da Comissão ou pelas agências de segurança dos Estados membros.

É também importante notar que, em 2003, os documentos apresentam um decréscimo severo no uso do termo security, demonstrando que este, como retórica política, perdeu largamente sua importância para os planos de gerenciamento das fronteiras externas que culminaram com a Frontex. Alguns meses antes da criação desta agência, quando as discussões sobre o conceito de IBM se tornaram mais intensas, as terminologias anteriormente analisadas foram muito mais freqüentes. Nesse sentido, como pode ser visto no gráfico a seguir, não é uma surpresa que a "Proposal for a Council Regulation establishing the European Agency for the Management of Operational Co-operation at the External Borders (que se tornou a Frontex), apresentada no dia 20 de novembro

\footnotetext{
${ }^{150}$ Neste documento, o Conselho apenas aponta quais são as ofensas que podem ser definidas como atos terroristas, por exemplo: "causing extensive destruction to a Government or public facility, a transport system, an infrastructure facility", "seizure of aircraft, ships or other means of public or goods transport", release of dangerous substances, or causing fires, floods or explosions the effect of which is to endanger human life", "threatening to commit any of the acts listed" (Conselho Europeu, 2002, p. 2).

${ }^{151}$ Para mais sobre esta proposta ver o documento referência 11994/02, do Conselho Europeu.
} 
de 2003, mencione, por exemplo, 125 vezes management, 62 vezes control, 45 vezes surveillance e apenas 8 vezes security $^{152}$. Ou seja, de acordo com a Comissão, a função principal da agência seria técnica, criando "a common core curriculum for border guards' training and research in technologies relevant for control and surveillance of the external borders respectively" (Comissão Europeia, 2003, par. 2).

Gráfico 6: Análise comparativa das referências a surveillance, control, management e security

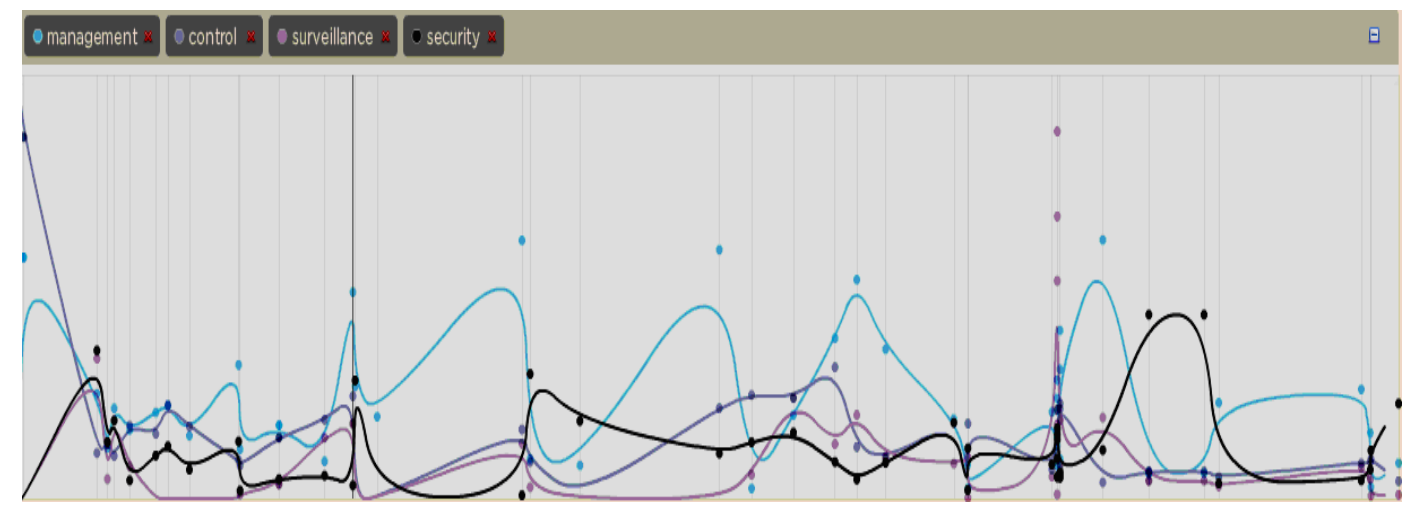

Portanto, é possível concluir que a estratégia de IBM, e não um discurso de ameaça existencial, foi central para a política de segurança da UE, sendo a principal influência para a criação da Frontex. Segundo Léonard (2011), esta estratégia consiste em "joining up all the activities of the public authorities of the member states relating to border control and surveillance including border checks, the analysis of risk at the borders, and the planning of the personnel and facilities required" (Léonard, 2011, p. 07). Desta forma, fica claro que os estudos sobre a criação da Frontex não devem focar nos grandes discursos securitários e momentos de radical inflexão política, conforme feito pela Escola de Copenhague. A alternativa teórica apresentada por Bourdieu e aperfeiçoada por Bigo, ao abordar atores que lidam com as práticas de vigilância e controle em sua rotina, se mostra mais capaz de entender o processo que levou à criação da Frontex.

\footnotetext{
${ }^{152}$ Na regulamentação final, aprovada pelo Conselho Europeu, estes números mudam para: 75 incidências de management, 20 de control, 16 de surveillance e apenas uma menção à security (EC, 2007/2004).
} 
Contestando as leituras da Escola de Copenhague para a evolução dos mecanismos de controle de fronteira na UE, Monar (2006) afirma que:

"[...] any official attempts to galvanize public opinion by a declaration of 'war on terror' and corresponding far-reaching measures would obviously face a major uphill battle. Presenting the terrorist threat essentially as a challenge requiring 'only' the improvement of law enforcement instruments is much more likely to generate broad political support" (Monar, 2010, p. 3).

Segundo Monar, as experiências ao longo do século XX com desrespeito aos direitos humanos criaram uma grande resistência em meio à sociedade europeia para políticas com orientações abertamente excludentes. Para o autor, a identidade europeia se pauta também na luta pela liberdade e democracia, logo: "Moving beyond a Law enforcement approach based on the observance of the European fundamental rights guarantees and the rule of Law principle would simply mean to break up the basic consensus on which the European construction rests" (Monar, 2006, p. 4). Assim, a retórica da "guerra ao terror", que justificaria medidas excepcionais para combater a ameaça da Al Qaeda teve pouca repercussão e adesão, sendo insuficiente para superar, por exemplo, as normas adotadas pela Convenção Europeia de Direitos Humanos. Nesse sentido, as medidas mais radicais só tiveram lugar no nível doméstico, onde houve debates sobre os limites da democracia e a necessidade de protegê-la com medidas excepcionais. No nível europeu a resposta aos atentados foi aprofundar a integração e pôr em prática algumas das medidas que amadureciam desde a incorporação do Acordo de Schengen no acquis communautaire. O melhor exemplo disso é justamente a Frontex, que não precisou de nenhuma alteração na legislação vigente para iniciar seus trabalhos.

Nesse contexto, levando-se em consideração a longa análise sobre as políticas de mobilidade e controle de fronteiras desde os anos 1970, é possível afirmar que a relação entre imigração e segurança não foi inaugurada depois de 11 de setembro de 2001. Ao contrário do previsto pelas abordagens de securitização, os atentados terroristas não foram responsáveis por uma nova forma de articulação de significados sociais, mas serviram "apenas" para reforçar o processo já em curso. Em resumo, um dos principais problemas de atores como 
van Krieken (2005), Norman (2006) e Lahav et al (2007) é que suas análises não desenvolvem uma pesquisa ampla e simplesmente não são capazes de perceber como as terminologias estudadas eram previamente utilizadas. Por fim, a crítica direta e crua de Jorry (2007) à literatura da Escola de Copenhague é muito bemvinda:

\footnotetext{
"the perception that post-September 11 and March 11 terrorist threats contributed to the securitization of JHA policies and migratory policies calling for tighter border controls at the EU's external borders and placing border security at the core of EU citizens' preoccupations cannot be sustained after a documental research (Jorry, 2007, p. 3).
} 


\section{5.}

\section{Exceção, Práticas e o Contínuo de Segurança}

No capítulo anterior buscou-se evidenciar as limitações das ferramentas propostas por Wæver e Buzan na compreensão dos fenômenos sociais. Através da análise do processo de criação de mecanismos de controle de fronteiras na UE, pôde-se perceber que a metodologia empregada pela Escola do Copenhague restringe o escopo das pesquisas e tem como consequência o favorecimento de leituras que tendem sempre a apontar para a novidade de processos que, na maioria das vezes, já tem raízes bastante sólidas. Por ter sido objeto de uma bibliografia especializada, o caso da Frontex é especialmente interessante para desmistificar a lógica da securitização e os argumentos que apontam para a descontinuidade, demonstrando que os atentados de 11 de setembro de 2001 foram "apenas" mais um elemento no longo processo que levou à constituição de uma agência semi-autônoma responsável pela produção de conhecimento sobre as fronteiras comuns europeias e aplicação de novas tecnologias de controle.

A incorporação das contribuições de Bourdieu - o que se deu pela análise quali-quantitativa dos documentos específicos sobre a Frontex, mas também de uma série mais antiga, que incorpora as primeiras decisões das comunidades europeias sobre a mobilidade de estrangeiros - permite uma abordagem que, embora reconheça a relevância dos discursos para a construção de ameaças, inclui outros atores e práticas em seus estudos e, portanto, que possui diferenças irreconciliáveis com a ferramenta proposta por Wæver e Buzan. Os problemas da lógica de securitização, no entanto, não se restringem a sua reduzida capacidade analítica. O arcabouço teórico da Escola de Copenhague, ao avançar uma compreensão da política que se pauta nos trabalhos de Schmitt sobre poder decisório e exceção, contribui para a reprodução de entendimentos sociais que partem de premissas antidemocráticas e, portanto, que promovem exclusão.

Assim, neste capítulo será avançada uma compreensão distinta para o processo de securitização, que tem como principal caracterísitica a denúncia das consequências éticas e políticas de trabalhos que seguem os padrões previstos pelos autores de Copenhague. Após entender as bases teóricas de Wæver e Buzan e as implicações de leituras que privilegiam o espaço da exceção, buscar-se-á 
apresentar mais a fundo os estudos produzidos por Bigo e Huysmans sobre o atual estado das políticas de exceção na Europa. Conforme dito anteriormente, esta dissertação tem o duplo objetivo de apontar os problemas teóricos das leituras críticas de segurança, e evidenciar as origens e consequências das práticas de exclusão (muito em função de questões de segurança) que marcam as políticas europeias para os imigrantes. Nesse sentido, será retomado o diagnóstico de Bigo (2002) sobre a/uma forma de governança do Estado liberal ("governmentality of unease") que se alicerça na percepção do risco e da insegurança para a construção do espaço político como o lugar da violência e da exclusão.

\subsection{Carl Schmitt, Giorgio Agamben e o conceito de política na Escola de Copenhague}

O amplo debate das ciências humanas sobre política e exceção chegou às Relações Internacionais, principalmente, a partir de dois autores, Agamben (1998 [1995], 2004) e Schmitt (2005 [1922]). Estes abordam um mesmo problema de pesquisa, mas trilham caminhos bem diferentes em suas análises. Enquanto o sociólogo alemão se debruça sobre as dificuldades de manutenção da unidade estatal frente aos desafios (riscos de fragmentação) impostos pelas disputas sociais, Agamben subverte o foco da análise e aborda os problemas decorrentes da atuação do poder soberano sobre a vida (em seu sentido biológico). Para Agamben, o objetivo final da política não é a unidade do Estado, mas sim a preservação da vida, daí sua preocupação acerca da atuação do soberano sobre os corpos dos indivíduos e a relevância dos constrangimentos gerados pelas leis (Agamben, 2004). Desta forma, revela-se a incidência de dois conceitos distintos sobre o espaço da exceção e sua relação com o político: Schmitt percebe a exceção como o resultado das decisões do soberano, que pode suspender a vigência das leis e unir o Estado por seu poder; e Agamben concebe o político como exceção, ou a exceção-como-regra, sendo estes espaços indissociáveis (Rahola, 2008).

Apesar de reconhecer a relevância da crítica de Agamben, a postura aqui adotada busca denunciar as conseqüências destas leituras sobre o espaço político, demonstrando que ao trabalhar com o conceito de exceção como uma categoria política, ambas marginalizam a sociedade como um domínio multidimensional de 
atuação e, portanto, produzem interpretações pobres sobre estruturas de poder e formas de resistência. Assim, além de entender a influência de Schmitt sobre a Escola de Copenhague, cabe aqui denunciar o impacto de algumas leituras alternativas que trabalham com o idioma da exceção.

\subsubsection{O soberano de Schmitt e a construção do inimigo na Escola de} Copenhague

Após os atentados de 11 de setembro de 2001, o trabalho de Schmitt foi recuperado pela literatura de segurança internacional como uma interpretação central para o dilema da superação do poder soberano (Behnke \& Bishai, 2007). A partir de Schmitt, diversos teóricos deste campo se debruçaram sobre as possibilidades de um regime de exceção e a ameaça que este representa para a governabilidade do Estado liberal (Williams, 2003; Taureck, 2006; Huysmans, 2006, 2008). Esta literatura teve como motivação os argumentos do governo Bush acerca da necessidade das democracias se defenderem frente à intolerância do terrorismo, tendo despertado preocupações também para a defesa destes regimes em relação a sua auto-subversão (Behnke, 2004). Esta argumentação está relacionada a um problema mais amplo para a ordem internacional. Logo após os atentados, duas interpretações sobre a natureza do terrorismo ganharam força: a primeira identificava nas ações da Al-Qaeda um crime de guerra e, portanto, demandava um julgamento dos responsáveis a partir das leis internacionais já existentes; a segunda afirmava se tratar de um fato totalmente novo na política internacional, um evento que por sua magnitude mudaria as regras do jogo e demandaria medidas excepcionais. Posteriormente, a própria UE avançou uma terceira leitura, que compreende a prática terrorista como crime comum, sendo necessários, portanto, meios para fortalecer a cooperação policial e a troca de informações sobre crime organizado. Segundo Gilles de Kerchove, Coordenador de Ações de Contraterrorismo da UE, "Terrorists have to be investigated, prosecuted and convicted wherever possible according to the normal rules of criminal law" (Kerchove, 2012, p. 5-6). No seio desta controvérsia estava a legitimidade de uma ação que suplantasse as previsões da Carta da ONU e inaugurasse um novo modelo de intervenção. Este debate e as disputas legais que se seguiram às medidas de segurança adotadas pelo Estado americano no pós-11 
de setembro remontam às questões levantadas por Schmitt sobre o direito e a política (Behnke, 2004).

Carl Schmitt produziu grande parte de seu trabalho no período entreguerras, quando o principal debate na área jurídica se dava em torno dos postulados de Hans Kelsen e a ideia de Teoria Pura do Direito ${ }^{153}$. Esta abordagem positivista demandava a adoção de uma lei pura, universal, e alheia a debates sociológicos ou políticos. Contrário a esta visão, Schmitt propunha justamente que o político fosse o principal componente do direito, sendo este inerente ao contex to social no qual as normas são formuladas ${ }^{154}$. Segundo este autor, existiria um espaço entre as normas e os fatos em si, o que implicaria na impossibilidade de aplicação automática da lei. Sendo impossível cobrir todas as possibilidades da ação humana em um regimento legal, em momentos de incerteza jurídica caberia a um corpo institucional aplicar as leis já existentes (ou criar novas) e, portanto, tomar decisões (imputar interpretações) sobre as analogias entre os fatos e as normas $^{155}$.

Tendo como paradigma a paralisia do governo alemão durante o regime da República de Weimar (1919-1933), Schmitt percebia a falta de capacidade de atuação do Estado como um grave problema para a manutenção da ordem. Um Estado impossibilitado de tomar decisões seria um Estado incapaz de resolver os problemas diários da sociedade e, em última análise, um Estado sem competência

\footnotetext{
${ }^{153}$ Preocupado com a contaminação ideológica e moral do Direito, Kelsen propunha a construção de uma teoria que reproduzisse os padrões das ciências naturais para o desenvolvimento de fundamentos jurídicos puros. Estes fundamentos não estariam ligados à cultura ou história local, mas sim à própria norma. Nesse sentido, atos sobre os quais não haveria previsão para um julgamento legal seriam tipificados a partir das normas existentes. Em último caso, o poder legal partiria da Constituição vigente, não da capacidade de decisão do líder político. Nas palavras de Kelsen: "Quando a si própria se designa como 'pura' Teoria do Direito, isto significa que ela se propõe garantir um conhecimento apenas dirigido ao Direito e excluir deste conhecimento tudo quanto não pertença ao seu objeto, tudo quanto não se possa, rigorosamente, determinar como Direito. Quer isto dizer que ela pretende libertar a ciência jurídica de todos os elementos que the são estranhos. Esse é seu princípio metodológico fundamental" (Kelsen, 2003 [1960], p. 1).

${ }^{154}$ Em "O Conceito do Político", de 1932, Schmitt apresenta os motivos pelos quais a lógica positivista do direito não deva ser considerada. Além disso, o autor levanta uma questão fundamental: sendo as leis produzidas, interpretadas e aplicadas pelos Homens, e tendo que as leis existentes não são capazes de cobrir todos os acontecimentos, quem poderá decidir sobre as novas leis? Para Schmitt, nos momentos em que as normas não prevêem uma determinada postura, o soberano deve assumir seu lugar de detentor real do poder e resolver a questão, pois o "político" sempre estará acima das leis (Schmitt, 2007 [1932]).

${ }^{155}$ Para Schmitt, a questão a ser resolvida é a incerteza gerada quando a autoridade legal prevista na constituição não tem capacidade para lidar com determinada situação. Neste cenário, deve caber ao soberano (aquele que detém o poder real) tomar uma decisão e fazê-la cumprir, pois para a continuidade dos procedimentos legais é mais importante que uma decisão objetiva seja tomada do que o contrário.
} 
para evitar as pressões fragmentárias no tecido social. Por isso, é fundamental que esteja claro (e seja inquestionável) o poder de "quem decide". O autor então propõe que o soberano tenha maior capacidade de ação e autonomia de decisão, o que evitaria a destruição da ordem vigente através das disputas partidárias ou do extremismo ideológico. A força do líder permitiria a reprodução do sistema representativo sem que a democracia parlamentarista fosse subjugada ${ }^{156}$.

Para Schmitt, o debate sobre exceção se coloca justamente neste ponto, pois é fundamental que em contextos não previstos pelo acervo jurídico o soberano seja capaz de agir. A ausência de leis é vista como a fonte para insegurança e violência, por isso se faz necessário garantir que o quadro normativo possa ser estendido. Conforme esclarece Huysmans, “[...] sovereign power needs to be able to act outside of the legal framework so as to constitute a constitutional order where non is" (Huysmans, 2008, p. 173).

Deste modo, Schmitt considera que o espaço da política está localizado entre a lei e o governo executivo, o que levanta dúvidas sobre quando a necessidade de transgressão legal nas democracias pode levar à ruptura com o regime e constituir ditaduras. Ou seja, ao conceber a política como um estado de permanente tensão, Schmitt opta por fortalecer os poderes ordenadores da sociedade, o que, segundo seus críticos, aponta para a superação do Estado de direito em prol de regimes autoritários.

Conforme visto no primeiro capítulo, é neste quadro teórico que a Escola de Copenhague baseia sua ferramenta analítica. Ao focar no papel dos líderes políticos na construção de determinado fenômeno como ameaça existencial, Wæver e Buzan reproduzem o argumento de Schmitt sobre o espaço de decisão dos soberanos. O processo de securitização é determinado pela pré-disposição de conceber a sociedade a partir da divisão entre amigos e inimigos (Freund und Feind), especificamente pelo medo do inimigo ${ }^{157}$ :

"For as long as the people exists in the political sphere, this people must, even if only in the most extreme case [...] determine by itself the distinction of friend and

\footnotetext{
${ }^{156}$ É importante ter em mente que a interpretação de Schmitt para a representação política é "de cima para baixo", o que o leva a desconsiderar a questão da autonomia dos indivíduos em regimes representativos.

${ }^{157}$ Nas palavras do próprio autor: "The specific political distinction to which political action and motives can be reduced is that between friend and enemy" (Schmitt apud Huysmans, 2008, p. 169).
} 
enemy. Therein resides the essence of its political existence. When it no longer possesses the capacity or the will to make this distinction, it ceases to exist politically" (Schmitt, 2007 [1932], p. 49).

Assim como, para Schmitt, a natureza do campo político é determinada por este cisma (amigo/inimigo), a construção de significados de segurança será, para Buzan e Wæver, pautada pela divisão entre momentos de normalidade democrática e de emergência, quando políticas extraordinárias (fora das regras pré-estabelecidas) serão adotadas. Ou seja, a securitização reflete (e reifica) a condição desta intensa divisão que Schmitt percebe como a essência do conceito de político. Esta enseja ainda uma concepção de política-como-guerra que, segundo alguns críticos, implica no fim de qualquer base para mediação simbólica e subverte a clássica afirmação de Clausewitz de que a guerra seria a política por outros meios (Agamben, 2004). Para Clausewitz, a guerra estaria restrita por seus objetivos políticos, servindo como um meio para alcançá-los. Na definição de Schmitt para o espaço político o extremo da guerra e a possibilidade sempre presente de deflagração de conflitos contaminam a prática política. Havendo uma dicotomia entre amigos e inimigos inerente à sociedade, a guerra se torna um elemento definidor da política.

Esta proximidade entre a Escola de Copenhague e Schmitt ocorre ainda no que tange ao espaço da decisão política ${ }^{158}$. Para ambos, é no momento da decisão que a essência do soberano se manifesta, pois quando as relações de oposição são extremadas, o soberano deve ter a capacidade de atuar acima das normas para conter o inimigo. Nas palavras de Williams, "It is when identities are securitised that their negotiability and flexibility are challenged, denied or suppressed. Under the conditions of 'existential threat' [...] to identities, a Schmittian logic of friends and enemies is invoked, and with it the politics of exclusion" (Williams, 2003, p. 519). Há, portanto, a previsão de autonomia para o soberano em relação aos códigos legais e a primazia da exceção sobre a norma, o que, como Williams prenuncia, causa exclusão.

\footnotetext{
${ }^{158}$ Nesse ponto, se faz necessário um cuidado com as diferenças apresentadas pelos autores no que tange ao conceito de decisão política. Ao falar de decisão, Schmitt menciona a escolha do soberano em si, já Buzan e Wæver veem a decisão, securitização/de-securitização, como um fenômeno social (Taureck, 2006).
} 
A Escola de Copenhague se apropria da terminologia de exceção a partir de uma visão nominalista, não como uma essência da política ${ }^{159}$. No entanto, apesar de focar na capacidade dos discursos de (ao dar nomes aos fenômenos) construir as questões de segurança, a leitura de Buzan e Wæver coloca o Estado como ator securitizante prima facie, o que estreita esta teoria e, na prática, a aproxima das proposições de Schmitt. Assim, independente dos aspectos do discurso, o campo é caracterizado pela urgência que revela certos imperativos ligados às prerrogativas do Estado. Colocando de outra forma:

"[...] by reifing the basic figurative elements of the security discourse, certain political prerogratives are reified as well, and this is to fall straight into Schmitt's trap. The exceptional event or situation dictates an exceptional response. It is not simply a dubious ethic, but a dubious metaphysic dictating a dubious ethic" (Neal, 2006, p. 34).

Em suma, Wæver e Buzan trabalham com um conceito schmittiano de política, que a define a partir do medo, deslocando os princípios de liberdade e justiça em prol da centralidade da decisão soberana. Neste cenário, a autoridade executiva absorve a capacidade de atuação política e, consequentemente, "as a political entity, the people only exist by being called into existence by the ruler" (Huysmans, 2008, p. 170). Desta definição do domínio da política decorre a radicalização das tensões sociais, o que se dá pela eliminação das bases normativa, moral ou instrumental sobre as quais os antagonistas ("amigos" e “inimigos”) possam negociar suas diferenças ${ }^{160}$ (Huysmans, 2006).

\footnotetext{
${ }^{159}$ Esta distinção é fundamental, pois as críticas aqui apresentadas à Escola de Copenhague não ignoram o caráter construtivista de seu trabalho e sua tentativa de desessencializar o domínio da segurança. A incorporação dos atos de fala e a divisão por setores operam no sentido de demonstrar como a lógica da exceção é socialmente contruída, o que, logicamente, difere os trabalhos de Wæver e Buzan dos argumentos de Schmitt.

${ }^{160}$ Indo além, é possível apontar espaços de convergência entre a abordagem da Escola de Copenhague e o neorealismo de Waltz. Esta aproximação ocorre em dois pontos específicos: a busca por sobrevivência e a relevância da distribuição de capacidades (Taureck, 2006). No primeiro caso, Buzan e Wæver pensam o conceito de segurança a partir das mesmas bases propostas por Waltz: enquanto o neorealismo defende que os Estados tem como objetivo primordial a busca por sua sobrevivência em um sistema internacional anárquico, para a Escola de Copenhague "Security means survival in the face of existential threats" (Buzan et al, 1998, p. 27). $\mathrm{O}$ segundo ponto está relacionado à definição dos líderes políticos capazes de produzir um ato de fala relevante para a sociedade (quem seria o autor securitizante válido?). Buzan e Wæver buscam na lógica de distribuição de capacidades a definição deste ator. Ou seja, quanto mais capacidades disponíveis ao líder, mais possibilidade de sucesso este terá no processo de securitização (Taureck, 2006).
} 
O impacto desta tensão na relação entre Estado e sociedade e, principalmente, nas formas de governos que se desenvolvem atualmente, será visto na última seção do capítulo. Por ora, devido ao sensível impacto na teoria política contemporânea, cabe entender as alternativas de Agamben ao conceito de política conforme formulado por Schmitt. Estas revelam alguns problemas bastante claros da conceituação aqui apresentada, mas também guardam suas limitações e implicações negativas.

\subsubsection{Agamben e a manutenção do idioma da exceção}

Em suas investigações sobre a dinâmica política na modernidade, Giorgio Agamben se vale da descrição do ambiente dos campos ${ }^{161}$ para abordar a relação crua existente entre o soberano e os indivíduos, na qual "sovereign power relies on the ability to decide on whether certain forms of life are worthy living" (Vaughan-Williams, 2009, 735). Segundo o autor, tornou-se lugar comum na ciência política a crítica às formas de dominação e exclusão presentes no trabalho de Schmitt sobre Estado e Direito. Os argumentos normativos de Wæver acerca dos riscos do processo de securitização e a importância do fortalecimento de mecanismos de checks and balances se refletem na profusão de trabalhos com foco nos perigos presentes à democracia. Estes tem como base o estudo de momentos de crise e a produção de retóricas de emergência por parte do executivo, denunciando as possibilidades de subversão. Agamben, no entanto, afirma que esta literatura tem uma natureza crítica bastante reduzida, sendo também um vetor de reprodução da dialética entre norma e exceção (padrões

${ }^{161} \mathrm{O}$ debate sobre a definição do espaço do campo e o que ele revela sobre a sociedade em questão é bastante amplo. Hanna Arendt, por exemplo, desenvolveu algumas das perspectivas mais influentes sobre este tema. De acordo com esta autora, "Todas as tentativas das conferências internacionais no sentido de estabelecer alguma condição legal para os apátridas falharam, porque nenhum acordo poderia jamais substituir o território para o qual um estrangeiro, dentro da estrutura da lei existente, poderia ser deportado. Enquanto a discussão do problema do refugiado girava em torno da questão de como podia o refugiado tornar-se deportável novamente, o campo de internamento tornava-se único substituto prático de uma pátria. De fato, desde os anos 1930 esse era o único território que o mundo tinha a oferecer aos apátridas" (Arendt, 2007 [1949], p. 317-318). Para Agamben, os campos refletem a crise das democracias liberais, sendo o espaço paradigmático onde a vida e o poder soberano se relacionam sem mediações. $\mathrm{O}$ autor procura definir este espaço não como um fato histórico, ou uma anomalia que pertence ao passado, mas como uma característica definidora do momento atual. Assim, campo pode ser definido como: "[...] the space that is opened when the state of exception begins to become the rule. In the camp, the state of exception, which was essentially a temporariry suspension of the rule of law on the basis of a factual state of danger, is now given a permanent spatial arrangement, which as such nevertheless remains outside the normal order" (Agamben, 1998 [1995], p. 96). 
colocados por Schmitt). Assim, Agamben busca avançar outra leitura, que rompe com a noção de espaços distintos entre o império da lei e a anomia, sendo o campo o local onde isso se manifesta mais claramente ${ }^{162}$. Nas palavras do autor, “O estado de exceção não é uma ditadura [...], mas um espaço vazio de direito, uma zona de anomia em que todas as determinações jurídicas - e, antes de tudo, a própria distinção entre público e privado - estão desativadas" (Agamben, 2004, p. 78).

Os postulados de Schmitt acerca da soberania descrevem o ambiente político como uma disputa para a delimitação do poder executivo. $\mathrm{O}$ soberano estaria ao mesmo tempo sob e sobre as regras, sendo limitado por esta em momentos de normalidade, mas usufruindo de poderes extraordinários quando necessário. Agamben rompe com esta descrição, afirmando que o processo de intensificação da politização - que culmina com a securitização - simplesmente não retrata as relações entre Estado e sociedade. O que está em jogo não é a forma de fazer política em meio à tensão mencionada, mas sim o que ocorre com a política quando as barreiras para a atuação soberana se tornam irrelevantes, transformando a exceção em regra ${ }^{163}$. Ou, conforme Agamben,

\begin{abstract}
"The decisive fact is that, together with the process by which the exception everywhere becomes the rule, the realm of bare life - which is originally situated at the margins of the political order - gradually begins to coincide with the political realm, and exclusion and inclusion, outside and inside, bios and zoe, right and fact, enter into a zone of irreducible indistintion" (Agamben, 1998
\end{abstract} [1995], p. 9).

\footnotetext{
${ }^{162}$ Agamben quer transformar a perspectiva para a abordagem da questão da exceção. Segundo o autor: "[...] o estado de exceção não é nem exterior nem interior ao ordenamento jurídico e o problema da sua definição diz respeito a um patamar, ou a uma zona de indiferença, em que dentro e fora não se excluem mas se indeterminam. A suspensão da norma não significa sua abolição e a zona de anomia por ela instaurada não é (ou, pelo menos, não pretende ser) destituída de relação com a ordem jurídica. [...] o conflito a respeito do estado de exceção apresenta-se essencialmente como uma disputa sobre o locus que lhe cabe" (Agamben, 2004, p. 39).

${ }^{163}$ Em Homo Sacer: sovereign power and bare life, Agamben se refere a esse processo. Para o autor: "What is at issue in the sovereign exception is not so much the control or neutralization of an excess as the creation and definition of the very space in which the juridico-political order can have validity. In this sense, the sovereign exception is the fundamental localization (Ortung), which does not limit itself to distinguishing what is inside from what is outside but instead traces a threshold (the state of exception) between the two, on the basis of which outside and inside, the normal situation and chaos, enter into those complex topological relations that make the validity of the juridical order possible" (Agamben, 1998 [1995], p.18-19).
} 
Assim, Agamben afirma que os debates contemporâneos nos Estados Unidos e na Europa sobre o equilíbrio entre segurança e justiça são, na verdade, ilusórios. A criação de Guantánamo e a proliferação de campos para alocação de imigrantes ilegais no continente europeu não refletiriam a vitória de um discurso de exceção, pelo simples motivo de que a distinção entre momentos de exceção e normalidade não existiria. De acordo com Agamben, este debate serve apenas como uma ferramenta ideológica que constrange a sociedade a observar a atuação do Estado segundo os padrões de Schmitt, evitando a percepção acerca de uma transformação fundamental para a natureza do espaço político (Agamben, 2004). Para o autor, "politically significant life runs its course without regard for law or legal practice and law becomes a self-referential practice that operates at a great distance from factual life" (Huysmans, 2008, p. 174).

Embora reconheça a relevância da denúncia feita por Agamben, Huysmans afirma que o trabalho do sociólogo italiano também contribui para a eliminação do domínio social no espaço político. No momento em que Agamben afirma que a vida, em seu sentido biológico, é o centro da atuação dos soberanos, cria-se uma relação de precedência das políticas do corpo em relação às categorias sociais (classe, nacionalidade, gênero e etc.). A lógica de exceção-como-regra visa a falsificar os argumentos a respeito da mediação normativa. Para Agamben, não existiriam distintos momentos de exercício de poder e este se daria ao largo das categorias sociais, atuando diretamente no corpo (o que explica o uso do termo biopolítica). Nesse sentido, o autor nega que estas categorias tenham um papel definidor na atuação do soberano, ou que sejam responsáveis por práticas de dominação distintas. Se o poder provém de uma dinâmica política a-social os determinantes gerados pela vida em sociedade são irrelevantes.

Há, contudo, um grave risco em se trabalhar com a terminologia de biopolítica como contraposição à lógica de sociopolítica. Como aponta Huysmans, a concepção de Agamben pode ser vista também a partir da anomia, pois ela existe somente em função de si mesma:

"It is defined neither through its relation to external legal, economic, and other ends nor through histories of the constitution and contestation of certain forms of life, like for example legal life, that is both mediated by and mediating law, and 
contests of universal norms, or class life, that is both constituted by and constituting socio-economic relations and conflict" (Huysmans, 2008, p. 175).

Deste modo, Agamben propõe uma leitura da exceção como a constatação da "vida pura", sem mediação, - o que o autor chama também de "corpos nus" (Agamben, 1998 [1995]). No permanente estado de exceção os indivíduos encontram sua autenticidade, sua forma objetiva (ou seja, sem interferência dos condicionantes sociais). Trata-se, portanto, de uma concepção da exceção que passa pela destruição do que é social no espaço político e, consequentemente, que incorpora uma noção alienante deste espaço.

O risco dos argumentos de Agamben reside no fato de que este não apenas despolitiza a política, ignorando as lutas sociais, mas simplesmente exaure totalmente este espaço, criando uma visão caótica na qual: “[...] not fear of the enemy but the collapse of order into anomic, self-referential life is the defining principle of politics" (Huysmans, 2008, p. 175). Para Agamben, o estado de exceção permanente causa a destruição da sociabilidade e de qualquer mediação que torne a vida humana uma vida sociopolítica. Assim, a alternativa apresentada pelo autor é entre a realidade dos campos e a vida em anomia, ou, entre a sociabilidade em um contexto de domínio do poder autoritário sobre os corpos e uma vida a-social, onde os corpos seriam livres e autênticos (Agamben, 2004).

Deste modo, Agamben consegue superar ontologicamente a questão da capacidade política (“quem decide"), antes central para Schmitt, mas também torna irrelevante a construção do grupo de indivíduos como um corpo social multidimensional. Por fim:

"By shifting the idiom of exceptionalism away from its constitutional, political framing while at the same time reproducing the anti-societal position that is central to Schmittean exceptionalism, Agamben's works shows how central the move against the societal is to exceptionalism. The reproduction of this common characteristic in conceptions of the exception is why the increasing use of the idiom of exception can be called [...] a jargon of exception" (Huysmans, 2008, p. 176).

\subsubsection{Por que evitar a lógica e o jargão da exceção?}


O debate sobre exceção que domina a literatura metateórica sobre a Escola de Copenhague é muito marcado pelos trabalhos de Schmitt e Agamben, partindo de suas perspectivas para verificar a aplicabilidade da ferramenta apresentada por Buzan e Wæver, mas raras vezes para refletir sobre o impacto ético e político desta ferramenta ${ }^{164}$. Nesse sentido, é fundamental recuperar o caráter da crítica à Escola de Copenhague que aborda as implicações do jargão da exceção para a ciência política e, em última análise, para a forma como enxergamos as relações sociais contemporâneas.

A reprodução do jargão, mesmo nas críticas de Agamben, não opera sem um custo. Os autores apresentados despolitizam a política, pois, se por um lado Schmitt trabalha com foco na decisão do soberano como capaz de sobrepujar a ordem democrática, por outro, Agamben percebe a vida no campo sem mediações sociais. Enquanto o primeiro não denota a devida importância ao substrato social que se perde (é violentado ou excluído) a partir da exceção, o segundo ignora a relevância do tecido social (e as relações objetivas que surgem a partir deste) para a política.

Indo além, ao observar a exceção como o elemento definidor do espaço político na modernidade, tanto Schmitt (e os autores de Copenhague), quanto Agamben

"[...] erase from the concept of politics a rich and constitutive history of sociopolitical struggles, traditions of thought linked to this history and key sites and temporalities of politics as well as the central process through which individualized bodily resistances gain their central sociopolitical significance" (Huysmans, 2008, p. 177).

Visto isso, cabe então a pergunta: como superar o conceito de político presente no trabalho de Schmitt e evitar críticas que avançam perspectivas alienantes sobre as relações sociais modernas? Bigo, Huysmans e alguns autores da Escola de Paris ${ }^{165}$ buscam em Foucault a resposta.

\footnotetext{
${ }^{164}$ Este é o caso dos trabalhos de Stritzel (2007), Mcdonald (2008) e Balzacq (2008).

165 Ver Neal (2006); Tsoukala (2008); Aradau \& van Munster (2007; 2008); Léonard (2010); Boswell (2007).
} 
Apesar de também trabalhar com o conceito de biopolítica e traçar um diagnóstico para a sociedade moderna que, em certos aspectos, se aproxima dos processos descritos por Agamben, Foucault não concorda que a vida no campo seria despida de qualquer mediação social ${ }^{166}$. Suas pesquisas sobre disciplina e o governo dos corpos criticam frontalmente as leituras que partem de argumentos jurídicos sobre a decisão política e a exceção, porém, o faz tendo em mente que a exceção-como-regra se constrói a partir de tecnologias de governo e do conhecimento prático de profissionais de segurança (Foucault, 2008). Ao contrário de Agamben, Foucault traz a história para sua explicação, evidenciando como processos de construção dos sistemas políticos, dos meios de produção e de outras dimensões da vida social constituem um dispositivo (dispositif) biopolítico de governo que define as relações na modernidade. Desta forma, Foucault se distancia da literatura que aponta o campo como anomia e que define o espaço político como a-social. Para Foucault, os dispositivos de governo são resultado de intensas (e perenes) lutas entre profissionais de segurança, que, por sua vez, enfrentam resistência dos indivíduos à disciplinarização (Foucault, 2008).

O jargão da exceção foi a marca da teoria política na segunda metade do século XX, ora voltada para a atuação do Estado frente à ameaça da guerra total e do colapso da ordem, ora preocupada com as possibilidades de subversão da democracia. Este jargão foi introduzido e reproduzido no campo da segurança internacional através do trabalho da Escola de Copenhague, que, se por um lado, empenhou-se na construção de uma ferramenta que percebia o jogo político a partir dos conceitos de Schmitt (Buzan et al, 1998), por outro, também demonstrou preocupação com esta visão e suas implicações para a democracia (Wæver, 1995; 2004; 2008). Ambas as leituras veem o político a partir de seu limite, de suas condições de ruptura com o Estado liberal. São leituras que não tem como enxergar a relevância das categorias sociais, do "povo" como uma multiplicidade de relações e práticas, pois simplesmente observam locais e momentos em que esses processos não existem (Huysmans, 2008).

Discursos sobre exceção reificam uma análise enviesada da soberania, que privilegia a decisão em termos de contingência, a anuência com a autoridade

\footnotetext{
${ }^{166}$ Enquanto Foucault concebe a biopolítica como um processo histórico de convergência da vida natural (zoe) com a vida política (bios), na qual a segunda determina o sentido da primeira, Agamben afirma que estes domínios são originalmente indissociáveis, sendo a correlação apenas mais exposta na modernidade.
} 
pautada pela necessidade e o julgamento das ações na "fronteira do normal". É um discurso que reifica dualidades (ou oposições dialéticas): ruptura/continuidade, norma/exceção e outras. Para evitar incidir no mesmo erro, Foucault propõe uma abordagem que considera os discursos ${ }^{167}$ e práticas não em termos de seu surgimento súbito, mas a partir das condições históricas que os tornam possíveis (Foucault, 2008 [1969]). Trata-se, portanto, de uma proposta de arqueologia do discurso que:

"não considera o contínuo como dado primeiro e último que deve dar conta do resto; considera, ao contrário, que o mesmo, o repetitivo, o ininterrupto constituem um problema tanto quanto as rupturas; o idêntico e o contínuo não são aquilo que é preciso reencontrar no fim da análise" (Foucault, 2008 [1969], p. 195).

Foucault opta por uma pesquisa que observe a formação de discursos (historicamente situados) e as configurações do poder, para assim compreender as transformações (o que é inédito) em termos de uma relação complexa, plural e dispersa tanto temporalmente quanto localmente. Desta forma, considera simplista apontar a exceção (1) como manifestação da decisão soberana dos líderes (Schmitt), (2) através de abordagens que contraponham espaços da vida nua e da vida política (Agamben) ou mesmo (3) sublinhando os atos de fala da elite política sobre problemas de segurança (Escola de Copenhague). Para o autor,

\begin{abstract}
"Rather then simply understanding the politics of discourses as the violent or surreptitious appropriation of a system of rules, or the hazardous play of dominations, archeology places more emphasis on relations between objects, subjects, concepts and strategies, the conditions under which each of these categories is constituted, and the way they interact and supply authority to each other" (Neal, 2006, p. 39-40).
\end{abstract}

\footnotetext{
${ }^{167}$ É importante ressaltar que a compreensão que Foucault avança acerca do discurso não é a mesma utilizada pela Escola de Copenhague. Para o sociólogo francês: "Certamente, os discursos são feitos de signos; mas o que fazem é mais que utilizar esses signos para designar coisas. É esse mais que os torna irredutíveis à língua e ao ato de fala. É esse 'mais' que é preciso fazer aparecer e que é preciso descrecer" (Foucault, 2008 [1969], p. 55).
} 
No que tange à crítica específica dos argumentos sobre excepcionalidade, o filósofo francês afirma que: "A ideia de um único corte que divide de uma só vez todas as formações discursivas, interrompendo-as com um único movimento e reconstituindo-as segundo as mesmas regras, não pode ser mantida ${ }^{168 "}$ (Focault, 2008 [1969], p. 196).

Foucault trabalha com o conceito de biopolítica, mas não o faz a partir de uma perspectiva totalitária. Para este autor, não há uma imposição pura da disciplina, pois os corpos nunca estarão totalmente nus. Partindo do exemplo de Agamben sobre os campos nazistas, é possível afirmar que, apesar do poder aparentemente supremo sobre a vida dos indivíduos aprisionados, a lógica do homo sacer não seria apurada, pois ainda haveria um grau de sociabilidade e, portanto, um grau de resistência. Os campos, para Foucault, são espaços em que o poder é produzido, são dispositivos de governança pelo qual a diferença é estabelecida. Trazendo esta perspectiva para um exemplo mais recente, Neal (2006) e Rahola (2010) buscam demonstrar como em Guantánamo, apesar das práticas diárias que visam "asujeitar" os prisioneiros e torná-los indivíduos puros, (logo, dóceis), o exército americano ainda é obrigado a enfrentar transgressão ${ }^{169}$.

O caso da base de Guantánamo serve ainda para ilustrar como os campos não são construídos a partir da exceção, mas de práticas administrativas que tornam possível às sociedades democráticas legitimar ações contrárias aos direitos humanos. Na modernidade, o campo não é o lugar do limite, mas sim um espaço construído por profissionais de segurança que advogam por mecanismos eficientes e técnicas banais de controle.

Assim, a questão central para a ciência política contemporânea não deveria ser como a lógica da exceção constitui o espaço da política na modernidade, mas sim como é possível que Estados liberais adotem práticas anti-democráticas em relação a determinados grupos sociais como uma forma de governo que objetiva garantir segurança e liberdade para outros grupos; e, fundamentalmente, como estas práticas se perpetuam e condicionam as diversas dimensões da relação entre

\footnotetext{
${ }^{168}$ Neste ponto, Foucault se aproxima da lógica dos campos formulada por Bourdieu. Ambos apontam a necessidade de pensar em uma rede de relações de poder, que constituem distintos domínios. Não é possível apenas um corte que se relacione às formações discursivas, pois há diferentes estruturas sociais em jogo e uma mesma prática pode ganhar significados opostos dependendo do campo em questão. Para mais, ver Bigo (2008c).

${ }^{169}$ Para uma leitura sobre Guantánamo que se baseia em Agamben, ver Vaughan-Williams (2009).
} 
Estado e sociedade. Em todos estes processos, o jargão da exceção não é um determinante.

\title{
5.2. (In)segurança e outras formas de governança
}

\begin{abstract}
"Seventy-two people were dying in front of me. [...] We received water on the first day from a helicopter. Nobody had died at the time. We showed to them small children like a one-year-old baby. Even the man inside the helicopter showed me a sign like he is coming back. He never came back again" (Kurke apud Nielsen, 2012c).
\end{abstract}

O depoimento reproduzido acima é um trecho da entrevista concedida por Abu Kurke, imigrante etíope que sobreviveu por 16 dias à deriva no Mar Mediterrâneo. Em abril de 2011, Abu estava acompanhado de outras 72 pessoas, das quais apenas 9 sobreviveram. Segundo o imigrante, neste período, a balsa bastante precária e com poucos suprimentos - foi avistada diversas vezes por helicópteros e navios europeus que, apesar da situação, se recusaram a resgatá-los. O tempo no mar só chegou ao fim quando a balsa foi levada pelas ondas de volta ao litoral da Líbia, onde os sobreviventes foram ainda presos e torturados (Nielsen, 2012c).

Relatos semelhantes se repetem em profusão entre os estrangeiros que tentam alcançar as fronteiras europeias. Conforme pode ser visto no mapa abaixo, milhares de pessoas morreram nos últimos anos ao tentar acessar o espaço europeu.

Mapa 2: Número de mortes nas fronteiras europeias ${ }^{170}$

\footnotetext{
${ }^{170} \mathrm{O}$ portal europeu de notícias, OWNI, produziu um mapa interativo baseado no número de pessoas mortas na travessia desde 1988. O mapa está disponível em: http://owni.eu/2011/03/04/app-fortress-europe-a-deadly-exodus/
} 


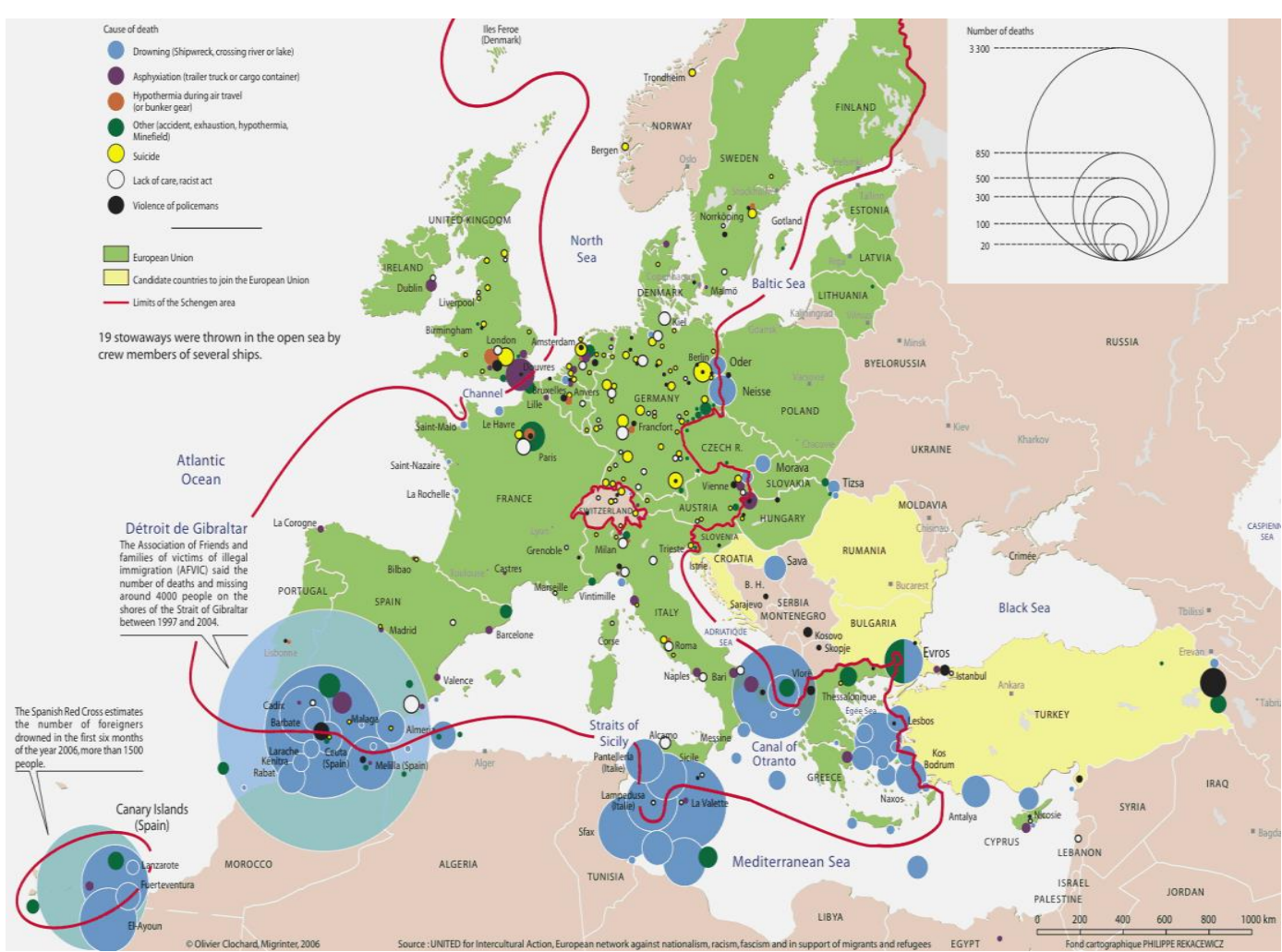

(Clochard, 2009)

Entre 1988 e 2009, estima-se 14 mil pessoas pereceram tentando driblar os controles de fronteira dos países da UE (Clochard, 2009). Apesar disso, a Frontex afirma ter salvo 23 mil vidas em missões de resgate, agregando este dado à demanda por mais investimentos nos mecanismos comuns de vigilância do mar. Ilka Laitinen, diretor executivo, afirma ainda que o Fórum Consultivo para Direitos Fundamentais foi a principal inovação desta agência nos últimos anos, sendo responsável pelo caráter cada vez mais humanitário de suas ações (Nielsen 2012b). Apesar da retórica oficial, diversas organizações não-governamentais denunciam o desrespeito pelos direitos dos imigrantes, que, não só continuam passando por experiências semelhantes a de Abu Kurke como, quando resgatados, muitas vezes são levados de volta ao país de origem (sem que haja a chance para que o pedido formal de asilo seja efetuado) ou são alocados em centros de detenção totalmente fora dos padrões exigidos pela Carta de Direitos Fundamentais da União Europeia (Migreurop, 2009; Human Rights Watch, 2011; Statewatch, 2012). 
Nos últimos anos houve uma proliferação do número de campos de detenção na Europa e nos países que fazem fronteira com o continente ${ }^{171}$. São direcionados para estes campos todos os estrangeiros presos ao chegar ao espaço de Schengen ${ }^{172}$, que acabam enfrentando péssimas condições higiênicas em celas superlotadas $^{173}$. Indo além, há inúmeros centros fechados à averiguação da sociedade civil. Assim, a imprensa e ONGs de direitos humanos não tem acesso aos detentos e estes perdem a comunicação com a família, com seus contatos na Europa e com advogados que, supostamente, os representam. Segundo denúncias dos grupos de pressão, não são raros os casos em que indivíduos ficam presos por meses sem que seu pedido de asilo seja avaliado e acabam deportados sem que tenham condições reais de fundamentar sua alegação (Migreurop, 2007). Este cenário reforça os argumentos sobre a "fortaleza europeia" (ver mapa 3) e levanta questionamentos sobre os limites da democracia no continente.

Mapa 3: Campos para detenção de estrangeiros na Europa e nos países do Mediterrâneo

\footnotetext{
${ }^{171}$ Os centros de detenção no norte da África são, em grande medida, fruto de parcerias dos governos nacionais com a Frontex e outras instituições europeias. Estes centros visam à prisão e averiguação de estrangeiros indetificados como imigrantes ilegais em potencial. São também o destino de indivíduos presos no mar que, ao invés de serem levados sob custódia para a Europa, são devolvidos para o país de origem das embarcações. As acusações de tortura, assassinato e das péssimas condições destes centros são bastante comuns. Apesar das constantes denúncias, a UE insiste em manter esta dimensão nos tratados firmados com os países da região, o que pode ser visto deste a assinatura da Declaração de Barcelona, em 1995, até a recente inauguração da União para o Mediterrâneo, em 2008. Para mais, ver Bicchi (2011).

172 São desconsiderados nesta análise os indívudos presos nos aeroportos internacionais das principais cidades europeias. Estes foram retirados da lista, pois, apesar da experiência traumática e no desrespeito aos direitos dos estrangeiros, em muitos casos o retorno é voluntário e a deportação leva poucas horas. Para uma análise autobiográfica, mas teoricamente bem fundamentada sobre esses espaços, ver Rangel (2012).

${ }^{173}$ A taxa de suicídios nestes campos é seis vezes maior que a taxa média dos países da UE (Migreurop, 2007). Em 2011, a agência de notícias europeia Euronews produziu um curto documentário sobre a situação destes campos em Lampedusa. Os depoimentos de imigrantes e autoridades estatais europeias podem ser acessados no seguinte endereço: http://www.euronews.com/2011/03/03/lampedusa-italian-island-at-the-sharp-end-of-immigration/.
} 


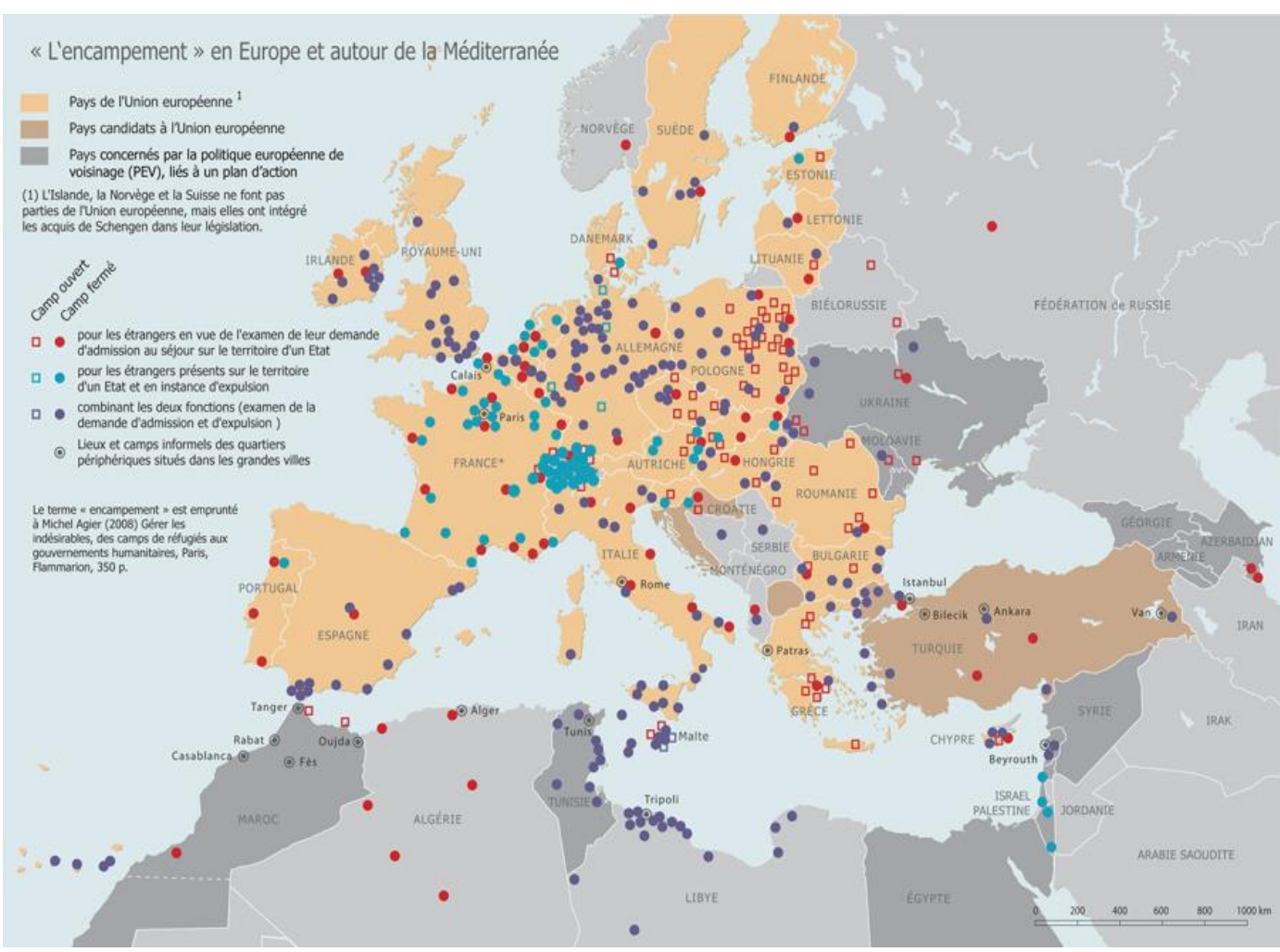

(Clochard, 2009)

Como os governantes europeus conseguem justificar a existência destes campos e dos maus tratos sofridos pelos estrangeiros? Indo além, como é possível que os centros de detenção sejam uma prática comum dos países e que sua proliferação na região seja incentivada pela UE sem que haja um amplo debate entre partidos e demais grupos políticos sobre as consequências da atual política de imigração ${ }^{174}$ ? Conforme visto no capítulo anterior, o trabalho dos profissionais de segurança e das agências europeias responsáveis por vigilância e controle são parte da explicação.

O conhecimento sobre segurança e imigração produzido por agentes de serviço de inteligência e centros de análise de risco são incorporados às práticas públicas sem que esse processo seja problematizado. Trata-se de um conhecimento visto como técnico ${ }^{175}$ e altamente especializado, do que decorre um

\footnotetext{
${ }^{174}$ Exemplos da indistinção entre as políticas de partidos de centro-esquerda e centro-direita no que tange à imigração são abundantes na Europa, como comprovam as recentes atitutes do governo de François Hollande para a extradição do povo Roma (Kushen, 2012); a aprovação por parte do governo de coalizão grego para a construção de uma cerca em parte da fronteira entre Grécia e Turquia (EurActiv, 2012c); e o acordo do governo conservador italiano com autoridades líbias para promover práticas ilegais de extradição (Nielsen, 2012b).

${ }^{175}$ Técnica se refere simultaneamente à "(1) a particular method of doing an activity which usually involves practical skills that are developed through training and practice, (2) a mode of procedure in na activity, and (3) the disposition of things according to a regular plan or design. [...] It is
} 
isolamento destes profissionais em relação ao jogo político diário. Os conteúdos dos relatórios apresentados e das indicações prescritas tornam-se bases sobre as quais a ação estatal deve ocorrer, não um ato político cujas consequências devam ser debatidas pela sociedade. Desta forma, práticas de segurança são incorporadas de forma acrítica à rotina política, mesmo que acabem por transformar radicalmente a forma pela qual o Estado lida com determinados fenômenos sociais.

Observando este fato, Huysmans e Bigo afirmam que os estudos de segurança precisam de um movimento analítico que transgrida os debates acerca de ameaças e subverta a busca central do campo por "mais segurança". Segundo estes autores, é fundamental elucidar a forma pela qual se dão as disputas pela definição do objeto da segurança, mas também o processo pelo qual a garantia de proteção para alguns gera insegurança para outros.

\subsubsection{Práticas ${ }^{176}$ e profissionais de (in)segurança}

O centro da argumentação da Escola de Copenhague está na interpretação de que os discursos são capazes de mobilizar ações, modulando a política segundo determinado padrão. A linguagem não é apenas uma forma de descrever um evento, mas sim um fator decisivo na construção do significado do fenômeno em questão. Logo, a linguagem de segurança é fundamental para que haja um processo de securitização ${ }^{177}$. A Escola de Paris trabalha segundo esta premissa

embedded in training, routine, and technical knowledge and skills, as well as technological artifacts" (Huysmans, 2006, p. 9).

176 A definição de prática aqui avançada está alicerçada na concepção de Bourdieu acerca do conhecimento praxiológico (em contraposição ao fenomenológico e ao objetivista), que tem como objeto "não somente o sistema das relações objetivas que o modo de conhecimento objetivista constrói, mas também as relações dialéticas entre essas estruturas e as disposições estruturadas nas quais elas se atualizam e que tendem a reproduzi-las, isto é, o processo de interiorização da exterioridade e da exteriorização da interioridade. Esse conhecimento supõe uma ruptura com o modo objetivista, ou seja, um questionamento das condições de possibilidade e, por isso, dos limites do ponto de vista objetivo e objetivante que apreende de fora as práticas como fato acabado, em vez de construir seu princípio gerador situando-se no interior do movimento de sua efetivação. [...] O conhecimento praxiológico não anula as aquisições objetivistas, mas conserva-as e as ultrapassa, integrando o que esse conhecimento teve de excluir para obtê-las (Ortiz, 2003, p. 40, ênfase do original).

${ }^{177}$ A influência de Derrida nos argumentos de Wæver fica clara na premissa da teoria de securitização que foca na influência prática do uso da palavra segurança. Esta percepção vem da concepção de Derrida de que o texto, ao dizer alguma coisa, importa pelo que ele faz. A ideia de que "não há nada fora do texto" é central para Wæver, sendo o que o levou a abordar o conceito de atos de fala. A contribuição de Derrida fica clara na Escola de Copenhague ao ignorar as análises 
teórica, mas vai além, incorporando as práticas diárias do conceito de segurança e sua expansão para outros domínios sociais. Assim, busca compreender a influência de processos tecnocráticos na construção do campo de segurança interna da União Europeia.

Os autores de Copenhague observam os atos de fala de líderes políticos, mas negligenciam a lógica que os condicionam e ignoram o papel de produção de conhecimento (e de significados) que advém das tecnologias empregadas por “[...] professionals who gain their legitimacy of and power over defining policy problems from trained skills and knowledge and from continuing using these in their work" (Huysmans, 2006, p. 9). Por não ser midiatizado, o papel destes especialistas é, geralmente, subestimado.

Assim, Huysmans e Bigo buscam trazer à luz as origens e impactos das técnicas para governar o perigo, o que os diferencia dos autores que apresentam uma abordagem puramente linguística para o processo de construção da insegurança. O decisivo, para estes autores, não é entender os atos de fala, mas sim como o conhecimento sobre segurança é disseminado em meio à sociedade $\mathrm{e}$ como determinadas visões são legitimadas. Trata-se de uma abordagem que considera os atos de fala como

“[...] result of structural competition between actors with different forms of capital and legitimacy over contradictory definitions of security and different interests. They are also dependents on the capacities of the field agents to patrol the boundaries of the field, to open or to restrict the definition of what security is, to block or limit the alternatives" (Bigo \& Tsoukala, p. 4-5).

Nesse sentido, o significado da segurança seria definido não por grandes atores performáticos, mas por um "efeito de campo". Trata-se de uma construção cotidiana de quais formas de violência são aceitas ou não. O campo da segurança não tem uma agenda nem um escopo definido. A atuação do Estado, ao contrário do que coloca Buzan et al (1998), não é marcada necessariamente pela busca por sobrevivência, muito menos por uma divisão entre questões internas e externas. O

acerca das "reais intenções" dos líderes ao construírem determinado fenômeno como ameaça (Taureck, 2006). 
processo que define a segurança e que leva determinados fenômenos sociais a serem vistos a partir da lógica deste campo é construído por

"[...] mundane bureaucratic decisions of everyday politics, with Weberian routines of rationalization, of management of numbers instead of persons, of use of Technologies, especially the ones which allow for communication and surveillance at a distance through databases and the speed of exchange of information" (Bigo \& Tsoukala, 2008, p. 5).

O foco das análises recai sobre os profissionais de segurança, públicos e privados, as instituições que produzem dados e informações técnicas, que trabalham rotineiramente com o gerenciamento de risco, pois são estes atores que mais contribuem para a construção dos significados de segurança e, portanto, para as "condições de possibilidade" para o sucesso dos atos de fala. Os discursos dos líderes tem impacto político, mas estes se dão em um contexto social anterior onde já há uma compreensão acerca do campo da segurança. Ou seja, a forma do ato de fala e o objeto sob o qual ele incide já são resultados do processo de construção dos significados socialmente aceitos do campo de segurança ${ }^{178}$.

Estes profissionais são capazes de pautar as políticas estatais por dois motivos: sua autonomia e penetração. A autonomia representa a distância formal da atividade política cotidiana, identificada com a dinâmica partidária na luta por votos. Isso se dá, pois há uma confusão entre a vida parlamentar e a esfera da política em si, como se ambas desempenhassem o mesmo papel na sociedade. Assim, sendo formalmente distantes dos atores partidários, é possível apresentar os profissionais de segurança como apolíticos. Esta percepção abre espaço para o segundo mecanismo, a penetração institucional de suas propostas. Sem que haja uma identificação dos argumentos destas instituições com as agendas de determinado grupo político, sua retórica acaba tendo uma capacidade de penetração maior, servindo como base para a ação do Estado independente dos partidos que formam o governo. Deste modo, o conhecimento produzido pelas agências acaba por pautar a atuação de diversos atores de segurança dos Estados e

${ }^{178} \mathrm{Ou}$, conforme colocado por Philipp Steinberg, "it is all to easy to eliminate discourse by reference to the 'expert-character' of the problems involved" (Steinberg, 2001, p. 18). 
da UE sem que as bases sobre as quais esse conhecimento foi construído sejam problematizadas (Bigo, 1994).

Posteriormente, Bigo adiciona outra dimensão as duas já mencionadas: o impacto da disputa de diferentes atores estatais e não-estatais pelo acesso às esferas mais altas de decisão. Estas disputas por centralidade e credibilidade são fundamentais para que o conhecimento produzido seja visto como legítimo. O fato de as informações apuradas por agentes de segurança permanecerem, na maioria das vezes, secretos contribui também para a imagem de que o trabalho destes profissionais não está diretamente ligado à política. Através dos processos descritos, os agentes de segurança não só acessam os salões presidenciais, mas apontam suas informações como a base necessária para a adoção de qualquer medida que os governos desejem tomar. Desta forma, tornam-se atores prépolíticos (Bigo, 2002).

Através de uma análise comparada da atuação destes profissionais na França, no Reino Unido e na Espanha, Laurent Bonelli (2008) afirma que, justamente por não haver uma percepção destas agências como instituições políticas, o controle parlamentar sobre sua atuação se dá de forma bastante reduzida, limitando-se à aprovação do orçamento e avaliação à posteriori das ações. Portanto, o modelo adotado pela UE para a fiscalização da Frontex, conforme visto na introdução, é replicado, fazendo com que o accountability do trabalho destes profissionais seja reduzido também dentro dos Estados.

Os serviços de inteligência ocupam um lugar bastante privilegiado nas estruturas governamentais, sendo, apesar do pouco accountability, responsáveis pela atuação do Estado em questões bastante sensíveis:

"They are both a vector - partially autonomous - for exercizing state violence, and gatekeepers of political order. They effectively help structure the general economy of contestation, which also makes them agents of the managed negotiation of the rules of disorder. Furthermore, in classifying and categorizing the information they collect, they actively participate in ring-fencing the political game. By qualifying or disqualifying certain groups by their own assessment, intelligent services can allow those groups to participate - or not - to this game" (Bonelli, 2008, p. 106). 
Em última análise, as agências de segurança e de inteligência formam um campo autônomo da política, que é marcado pela ilusão de um conhecimento específico, um know-how de tecnologias que só é partilhado por instituições semelhantes. Desta forma, constitui-se um capital político (ou poder simbólico, conforme o termo colocado por Bourdieu) marcado pelo conhecimento técnico. Este capital é construído e disseminado através de relações pessoais e profissionais. Os indivíduos que trabalham nestas agências seguem uma rotina burocrática, um treinamento específico, formulado para que haja uma internalização das práticas e das crenças da agência. É possível identificar um grau de manutenção da equipe destas instituições que não se repede nos demais órgãos do governo (Bonelli, 2008). Assim, cria-se um ethos institucional muito forte que se reflete no comportamento diário dos indivíduos e, portanto, na atuação da agência. Ou seja, o prestígio do especialista depende, em larga medida, de sua posição em meio ao campo dos profissionais de segurança. A construção das redes de profissionais e a adoção de um comportamento semelhante entre este grupo ficam bastante claras na declaração de um oficial da polícia britânica ${ }^{179}$ (Scotland Yard) acerca da cooperação com o PWGT:

\begin{abstract}
"I cannot stress too much the importance of the police working group across the whole field of terrorism in Western Europe, including Northern Ireland. We know these people, they are our personal friends, they come here to the Yard when they happen to be in London. We make contact with them when we go abroad, regardless of what we are going for. It has become a very solid group of working colleagues. We trust each other implicitly and pass information to each other without question (Bresler, 1992, p. 192).
\end{abstract}

Este mesmo processo se repete no campo de estudos de segurança, mais particularmente na literatura sobre terrorismo. Sendo um dos temas mais presentes na mídia ao longo da última década, seria normal que os especialistas convidados a apresentar suas opiniões sobre este fenômeno e a propor as melhores formas de combatê-lo tivessem origens variadas. No entanto, estudando a participação de pesquisadores na mídia americana e inglesa desde a década de 1970, David Miller

\footnotetext{
179 Bresler não identifica o oficial, menciona apenas que este pertence ao departamento de cooperação com a Europa.
} 
e Tom Mills (2009) demonstram que esse não é o caso. Ainda nos anos 1970 e 1980, quando esta literatura começou a se estruturar como um campo de estudos, um pequeno grupo de professores universitários dirigia pesquisas em think-tanks, ocupava os cargos de assessoria no governo e monopolizava os artigos na grande mídia. Todos tinham origens semelhantes e dialogavam intensamente entre $\mathrm{si}^{180}$, mas abriam pouco espaço para que novos temas e autores fossem incorporados. Criou-se uma rede de comunicação informal, mas que mantinha também revistas e encontros acadêmicos, bases de dados e dividia financiamentos e ideias (Miller \& Mills, 2009). Fortaleceu-se, portanto, um pensamento hegemônico no campo (uma elite acadêmica) com mais prestígio na mídia que fundamentou as políticas adotadas no período. Este mesmo grupo passou a trabalhar diretamente com militares, policiais, agências de inteligência e com a indústria de armamentos, difundindo sua visão sobre o terrorismo, expandindo a rede de contatos e, consequentemente, adquirindo o que Bourdieu chamou de poder simbólico.

A forma pela qual este campo se organiza atualmente é uma consequência direta dos processos descritos, sendo responsável pela pobreza teórica e pela desligitimação de abordagens alterantivas. Assim:

\begin{abstract}
"In terrorism research, the influence of knowledge producers is severely skewed by the limited types of data used: the invisible college's ${ }^{181}$ publications, government documents and media coverage. Thus, development of knowledge in
\end{abstract} terrorism research has resulted in [...] political bias and policy-oriented studies" (Reid, 1997, p. 101)

Disso decorre uma distorção na representação de determinada postura ideológica em relação às demais. Mesmo que o campo de estudos sobre terrorismo tenha se diversificado, o grupo de autores mencionados (e seus alunos), mantém a centralidade no que tange ao acesso a financiamento, participação no governo e espaço na mídia. Esta distorção fica mais clara a partir da comparação

\footnotetext{
${ }^{180}$ Miller e Mills destacam os trabalhos de David Rapoport, Martha Crenshaw, Brian Jenkins, Paul Wilkinson, Yonah Alexander, Walter Lacqueur e Ariel Merari. Todos tiveram passagens pela RAND Corporation, pelo Institute for the Study of Conflict e pelo Center for Strategic and International Studies da Universidade de Georgetown.

${ }^{181}$ O conceito de "invisible college" surgiu na década de 1960 na área de sociologia da ciência. Um de seus formuladores foi Derek de Solla Price, que usava este termo para se referir às redes informais de comunicação entre cientistas que acabam por formar uma elite acadêmica que domina o campo de estudo em questão. Para mais, ver Price (1971).
} 
dos artigos mais citados entre acadêmicos e os especialistas com maior incidência na imprensa. Apesar de as abordagens ortodoxas não serem mais a maioria, estas ainda mantem o contato com grandes corporações (ver gráfico 7) e são capazes de difundir suas perspectivas de forma disproporcional (Miller \& Mills, 2009).

Gráfico 7: Rede de especialistas em terrorismo

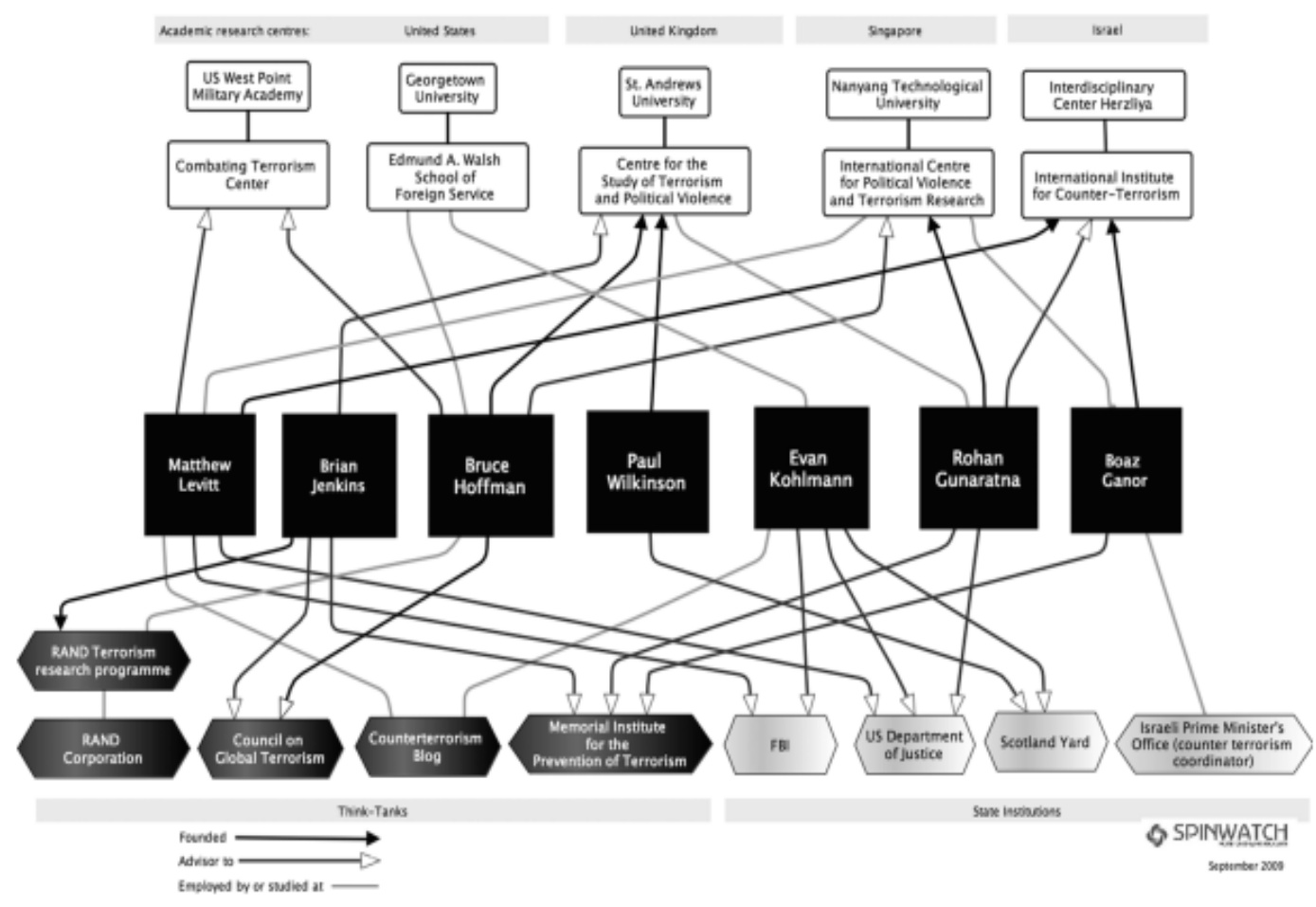

Os ambientes político-tecnocráticos ajudam a definir a forma pela qual o governo abordará determinada questão e as disputas internas neste ambiente são centrais para a construção de significados sociais. Assim, tanto o debate acadêmico acerca da amplitude dos temas de segurança internacional quanto as disputas entre profissionais de segurança sobre o escopo de atuação e a dimensão das ameaças definem as ações estatais.

\subsubsection{Securitização como um contínuo, o "banóptico" e as consequências deste processo}

Conforme mencionado anteriormente, a literatura sociológica dos estudos de segurança - abordada até aqui - tem como um dos pontos de partida o trabalho 
de Foucault acerca das formas de governo do Estado moderno. O autor francês, no entanto, não tem um trabalho linear, apresentando uma inflexão significativa ao longo dos anos e desenvolvendo pesquisas no final de sua carreira que rejeitam, por exemplo, parte das hipóteses que buscava comprovar em "Vigiar e Punir", seu clássico livro publicado em 1975.

Em "Segurança, Território, População" (2008), Foucault afirma que o poder do soberano não está totalmente refletido no mecanismo de punição, apesar de estar relacionado a este processo. Neste livro ${ }^{182}$, o autor tenta ir além de suas pesquisas sobre disciplinarização e o Estado policial, reestruturando seus estudos sobre soberania para focar nas análises acerca das formas de governo e dos dispositivos para o gerenciamento da população no Estado liberal. Assim, afastase da tentativa de formulação de uma teoria geral sobre o poder, aproximando-se de uma abordagem que define a segurança não através da exceção ou coerção, mas sim da normalidade e liberdade. Trata-se de um dispositivo que pode ser interpretado como:

"[...] a form of contingency grasping different contents. Security is more a name than a dispositive articulating discourses and practices of a certain kind. Security reduced to uncertainty, to the aleatory and the probability calculus articulating legal and disciplinary mechanisms is not sufficiently coherent and has not the consistency of law and discipline" (Bigo, 2008b, p. 97).

Nesse sentido, Foucault reconceitualiza os dispositivos modernos de segurança, demonstrando que estes não são construídos a partir de discursos de controle, mas sim da lógica da liberdade de movimento. As incertezas do futuro e os riscos sempre presentes, não condicionam discursos de limites e fronteiras, mas de integração e alargamento. Esta retórica, no entanto, vem acompanhada da preocupação com a coleta de informação e conhecimento sobre as possibilidades, envolvem um cálculo de probabilidades que guia os mecanismos de governança $^{183}$. Assim, Foucault afirma que:

\footnotetext{
182 "Segurança, Território, População" é uma compilação dos cursos ministrados por Foucault em 1977 e no início de 1978.

${ }^{183}$ Trata-se de um mecanismo que se difere um pouco do processo de disciplinarização descrito por Foucault em algumas de suas obras mais clássicas, especialmente "Vigiar e Punir".
} 
“[...] security regulates without prohibiting or prescribing, but possibly making use of some instruments of prescription and prohibition, by responding to a reality in such a way that this response cancels out the reality to which it responds - nullifies it, or limits, checks, or regulates it" (Foucault, 2008, p. 72).

Os dispositivos de segurança do Estado liberal contemporâneo apresentam os mecanismos de manutenção da ordem a partir de um simulacro de liberdade, por isso que, apesar da proliferação de agências e profissionais responsáveis pelo controle de fronteiras na União Europeia, não é possível identificar um processo de securitização. O discurso do Estado liberal e de suas burocracias, conforme visto através do ANTA, não é sobre segurança, mas sim liberdade e eficiência. Nesse discurso, a oposição entre liberdade e segurança perde o sentido, podendo ser ambas componentes de uma mesma política, ou, conforme colocado por Bigo: "[...] freedom is nothing else but the correlative of the deployment of dispositif of security and security is nothing else but the correlative of the deployment of freedom capacity of circulation" (Bigo, 2008b, p. 98). Este processo fica claro, por exemplo, no texto do Tratado de Amsterdã, no qual consta que:

“[...] the Treaty of Amsterdam also opens the way to giving 'freedom' a meaning beyond free movement of people across internal borders. It is also freedom to live in a law-abiding environment in the knowledge that public authorities are using everything in their individual and collective power [...] to combat and contain those who seek to deny or abuse that freedom" (Conselho Europeu, 1998, par. $\mathrm{VI})$.

Trata-se de uma articulação entre os conceitos de liberdade e segurança que percebe a primeira como uma qualidade da segunda. Nesta visão acerca do Estado liberal, não faz sentido falar em exceção. A proteção passa pela transformação da população em estatística e pela distribuição matemática dos riscos que são infringidos a determinado grupo. A partir das estatísticas extraídas pelos cálculos racionais, os profissionais de segurança são capazes de traçar perfis de risco e estabelecer mecanismos tecnológicos que possam identificar estes perfis em meio à sociedade sem que haja coerção intensiva. 
Isso se reflete na atuação da Frontex. Segundo dados do CIREFI ${ }^{184}$, em 2000, 620 mil indivíduos foram averiguados ao cruzar as fronteiras do Espaço Schengen (Bertozzi, 2008). Em 2010, já com as operações da Frontex em andamento, este número foi reduzido, para 104 mil (Frontex, 2011). O largo uso de tecnologia faz com que não seja mais necessário parar todos os indivíduos na fronteira e submetê-los aos mecanismos de controle. Estes mecanismos são mais escondidos, sua eficiência reside no fato de que, apesar de todos serem vigiados, apenas aqueles que se adéquam ao perfil de risco percebem este controle, sendo barrados nos limites nacionais. Para a maioria, a vigilância se dá sem que a sensação de fluidez de trânsito e liberdade seja afetada, mas para a minoria que incide na categoria de indesejados, a realidade não é a mesma.

Nesse sentido, a segurança não é uma forma de guerra e de exceção, nem se estrutura através do modelo do panóptico ${ }^{185}$; não se trata do controle de todos, mas da produção de categorias, da adoção de perfis de risco e do monitoramento de ações futuras. Este dispositivo de governo opera através da lógica da expansão dos domínios de segurança (uma leitura distinta do processo de securitização), no qual diferentes categorias são incluídas nas "listas-negras" dos profissionais do Estado. Assim, apesar da possibilidade de a população como um todo ser incluída nesta lógica, ela está voltada para as margens, para as categorias de indivíduos que potencialmente afetam a normalidade. Desta forma, segurança produz insegurança, excluindo determinados grupos em nome da proteção de outros e tornando a descriminação uma ferramenta cotidiana do Estado. De fato, "It abnormalises the margins and creates boudaries within the social space" (Bigo, 2008b, p. 105).

\footnotetext{
${ }^{184} \mathrm{O}$ Centre for Information, Discussion and Exchange on the Crossing of Frontiers and Iimmigration foi criado junto à Comissão em 1994 para monitorar a movimentação nas fronteiras. Em 1999, este centro implementou um mecanismo de aviso sobre informações acerca da imigração ilegal.

${ }^{185}$ Focault nega algumas das análises presentes em seus trabalhos anteriores, sendo o fenômeno do panóptico o principal deles. Nestes cursos, Foucault afirma que: "The idea of the panopticon is a modern idea in one sense, but we can also say that it is completely archaic, since the pacoptic dispositive basically involves putting someone in the centre - an eye, a gaze, a principle of surveillance - who will be able to make its sovereignty function over all the individuals' places within the mechanics of power. To that extent we can say that the panopticon is the oldest dream of the oldest sovereign. [...] on the other hand what appeared now, is not the power which would take the form of an exhaustive surveillance of individuals, [...] but the set of dispositifs which, for the government and those who governed, make relevant very specific phenomena which are not exactly individual phenomena, [...] although individuals featured in them in a certain way, and there are specific processes of individualization" (Foucault, 2008, p. 97).
} 
Em um de seus trabalhos mais citados no campo da segurança, "Security and Immigration: Toward a Critique of the Governmentality of Unease", Bigo (2002) aborda este mesmo processo a partir de uma preocupação central:

\begin{abstract}
"The professionals in charge of the management of risk and fear especially transfer the legitimacy they gain from struggles against terrorists, criminals, spies, and counterfeiters towards other targets, most notably transnational political activists, people crossing borders, or people born in the country but with foreign parents" (Bigo, 2002, p. 64).
\end{abstract}

Desta forma, o autor procura demonstrar que a expansão da agenda deste campo, não é apenas um problema para profissionais de segurança e acadêmicos, sendo uma questão decisiva para a forma pela qual a sociedade se organiza. Tratase de uma abordagem que denuncia o uso da tecnologia como uma "verdade não política", que demonstra que este conhecimento técnico nada mais é que uma ferramenta dos profissionais de segurança na busca por validação de seus argumentos. Na disputa diária por poder simbólico dentro do campo da segurança, estes profissionais reúnem dados e informações sobre determinados grupos e formulam hipóteses sobre a relação entre terrorismo, crime, desemprego e imigração, mesmo que outros atores sociais, como a Igreja, ONG's e think-tanks, apresentem fortes evidências contrárias a esta lógica ${ }^{186}$ (Bigo, 2002).

Assim:

"[The] securitization of the immigrant as a risk is based on our conception of the state as a body or a container for the polity. It is anchored in the fears of politicians about losing their symbolic control over the territorial boundaries. [...] It is a structural unease in a 'risk society' framed by neoliberal discourses in which freedom is always associated at its limits with danger and (in)security" (Bigo, 2002, p. 65).

\footnotetext{
${ }^{186}$ Bigo afirma ainda que "Migrant, as a term, is the way to designate someone as a threat to the core values of a country, a state, and has nothing to do with the legal terminology of foreigners. The word 'immigrant' is a shibboleth" (Bigo, 2002, p. 71). Assim, é realçado um importante paradoxo: se a imagem nacional do imigrante é diferente entre os Estados ${ }^{186}$, como podem os serviços de segurança trabalharem juntos em nível continental? Bigo explica que "if each security service uses the word 'immigrant' as a sign of danger, a consensus is possible. [..] Each country can then sell its fear to the other country [...] in what amounts to a stock exchange of security." (Bigo, 2002, p. 71).
} 
Nesse sentido, a transformação da imigração em um tema de segurança se torna parte de um processo mais amplo de governança que assegura ao Estado seu papel de provedor de proteção dentro de determinado território e, consequentemente, que permite que o Estado se mantenha como um campo (no sentido bourdiesiano do termo) central para as relações sociais. No entanto, a consolidação deste modo de governo demanda a implementação de novos mecanismos que funcionem como fontes para a reprodução do contexto de risco. No nível europeu, a Frontex desempenha este papel social, sendo responsável pela coordenação e expansão das práticas de (in)segurança. As figuras de linguagem que retratam imigração como uma "corrente/fluxo" ou "penetração/invasão" são profundamente influenciadas por estes profissionais ${ }^{187}$, sendo por eles utilizadas como parte da justificativa para ampliação dos mecanismos de vigilância ${ }^{188}$.

Uma vez criada, a Frontex se tornou uma ferramenta de governo importante, trabalhando de forma a retratar os fenômenos sociais através de lentes de segurança e disseminando, por meio de relatórios anuais e análises de risco, sua visão entre os Estados membros da UE. Neal ressalta o fato de esta agência trabalhar diariamente com o conceito de risco, "moving away from the political spectacle of the security emergency in favour of a quieter and more technocratic approach" (Neal, 2009, p. 348). Assim, a Frontex é fruto de, mas também coresponsável por, um novo modo de governar que abre espaço para que políticas restritivas antes vistas como controversas se tornem normais e/ou aceitáveis.

Essa dinâmica opera como uma técnica de governo, concentrada no medo e em um inimigo que é sempre fluído, fácil de definir, mas difícil de liquidar. Enquanto política, serve para legitimar a noção de vigilância permanente, direcionada prioritariamente ao inimigo específico (Bigo \& Walker, 2009). Assim, este modo de governo implica em iniciativas violentas de diferenciação que se materializam em atos de xenofobia em relação a diversas categorias sociais que passam a ser rotuladas como "outros", sendo tratados como as fontes potenciais de ameaças que precisam ser controladas pelo Estado. "The resulting

${ }^{187}$ A análise através do projeto ANTA pode, mais uma vez, ajudar na visualização deste processo. Entre os atentados do dia 11 de setembro de 2001 e a proposta formal sobre a criação da Frontex, uma período de dois anos, as instituições europeias produziram sete documentos relacionando "flow" e "migration". Após a criação e operacionalização da agência, 24 documentos com esta mesma relação já foram divulgados.

${ }^{188}$ Lógica que está baseada na ilusão de que seria possível controlar o movimento de indivíduos nas fronteiras dos Estados (Bigo, 2002). 
picture of the world [conforme retratado pelas agências de segurança] is one of chaos and urban insecurity" (Bigo, 2002, p. 81).

Bigo argumenta ainda que a consolidação do que ele denomina "war politics" leva a uma forma de governo pós-moderna definida como:

"The form of governmentality of postmodern societies is not a panopticon in which global surveillance is placed upon the shoulders of everybody, but a form of ban-opticon in which the technologies of surveillance sort out who needs to be under surveillance and who is free of surveillance because of his profile. This form of $[\ldots]$ state seems to renounce notions of a social contract and to transform misgiving in a mode of ruling" (Bigo, 2002, p. 82, ênfase nossa).

Essa técnica de governo do risco não é baseada na lógica de resposta a atos criminosos, mas sim na noção de antecipação, segundo a qual um grupo visto como potencialmente perigoso - no caso, os imigrantes -, é definido como uma ameaça não por alcançar as fronteiras, mas apenas pela possibilidade de movimento, não por se articular com grupos terroristas, mas por serem "propensos" a isso. Nesse sentido, trata-se de uma política de exclusão na qual, para alguns se sentirem seguros, outros precisam ter sua liberdade restringida. É uma narrativa distinta sobre o contínuo de segurança que retrata este conceito não como positivo - quanto mais segurança, menos risco -, mas como uma perspectiva eticamente controversa, na qual o âmbito da segurança é cercado por espaços de insegurança. Desta maneira, a lógica é a do sacrifício da liberdade de alguns a fim de alcançar a ilusão proteção de outros, definida por Bigo como um processo de (in)securitização:

"[...] the (in)securitization process has not only to do with a successful political speech act transforming the decision-making process and generating politics of exception often favoring coercive options. It has to do with more mundane bureaucratic decisions of everyday politics, with Weberian routines of rationalization, of management of numbers instead of management of persons, of use of technologies, especially the ones which permit communication and surveillance at a distance through databases and speed of exchange of information" (Bigo, 2008a, p. 127) 
Este discurso fica bastante claro entre os defensores da Frontex. Antonio Vitorino, ex-comissário para justiça e assuntos internos, ao alegar a necessidade de um gerenciamento integrado de fronteiras afirma que "Security is a means of achieving freedom. Security and freedom go hand in hand" (Vitorino apud van Munster, 2004, p. 200). Não se trata, portanto, de uma escolha, mas sim uma compreensão destes dois conceitos como indissociáveis. O mesmo discurso se repete entre outros especilistas europeus de segurança. Stefano Bertozzi, exassessor de Franco Fratinni, justifica a criação da Frontex afirmando que seu trabalho faria a União "more hospitable to bona fide travellers and more hostile to others". (Bertozzi, 2008b, p. 27).

Trata-se de uma deturpação da lógica democrática que se reforça através da institucionalização da exclusão. A face violenta do Estado não está voltada para todos os cidadãos, mas apenas para determinados grupos de indivíduos que são categorizados pelos profissionais de segurança como vetores de risco. Nesse contexto, torna-se aceitável o número de mortos nas fronteiras europeias, deixam de ser problemáticas as péssimas condições nas quais os imigrantes são mantidos em centros de detenção e torna-se possível justificar, por exemplo, a política do "atire para matar" da polícia britânica e o consequente o assassinato de Jean Charles de Menezes ${ }^{189}$. Afinal, mesmo com um aparato tecnológico avançado, mecanismos de identificação biométrica e câmeras de vigilância, os profissionais de segurança ainda erram.

\footnotetext{
${ }^{189}$ Jean Charles de Menezes era um imigrante brasileiro que residia em Londres. Em 2005, logo após os atentados terroristas em algumas estações de metrô da capital britânica a Scotland Yard iniciou uma ampla investigação e liberou a seus oficiais o uso de armas de fogo na contenção de possíveis ameaças. Jean Charles foi confundido com um imigrante árabe e foi assassinado dentro de um vagão quando já estava rendido pelos policiais. Para uma análise teoricamente informada sobre o caso, ver Vaughan-Williams (2007).
} 


\section{6.}

\section{Conclusão}

Ao longo da dissertação, buscou-se, fundamentalmente, responder a duas perguntas: quais foram as condições políticas que tornaram possível a criação da agência de controle de fronteiras da UE (Frontex)?; e quais as consequências metodológicas, éticas e políticas de se compreender diferentes fenômenos sociais segundo a lógica do risco? Estas perguntas não poderiam ser dissociadas, pois as condições que possibilitaram a criação da Frontex surgiram a partir de um longo e contínuo processo de articulação entre significados de segurança e a temática da imigração, o que, por sua vez, está diretamente relacionado com o debate metateórico dos estudos de segurança. Nesse sentido, esta dissertação se valeu da literatura empírica sobre a criação da Frontex, para fundamentar a crítica mais ampla à parte dos autores do campo que desenvolve pesquisas sobre exceção e securitização.

O enorme fluxo populacional que busca acesso ao Espaço de Schengen todos os anos representa, certamente, um desafio para a UE. Se, por um lado, além da demanda por trabalhadores qualificados e turismo, a União se consolidou em torno de ideais de liberdade e justiça, o que implica também na livre circulação de pessoas, por outro, há o receio de que a imigração desenfreada possa gerar problemas sociais, econômicos e, principalmente, de segurança. Nesse sentido, a gradual eliminação dos controles de fronteiras gera tensões entre a percepção dos perigos que isso acarreta e a necessidade de um espaço interno mais dinâmico, onde recursos e forças de trabalho possam se movimentar mais facilmente. Esta tensão envolve o equilíbrio entre o imperativo da segurança e os ganhos econômicos e políticos advindos da criação do espaço interno comum. Para resolvê-la, a UE optou por investir em mecanismos de controle de fronteiras que sejam mais eficientes, capazes de facilitar a entrada de estrangeiros desejados e bloquear o acesso àqueles que sejam vistos como potencialmente prejudiciais.

No dia 18 de novembro de 2003, Antonio Vitorino, então Comissário para Justiça e Assuntos Internos, apresentou oficialmente a proposta de criação da Frontex. Nesta proposta, Vitorino esperava cobrir as deficiências acarretadas pela falta de coordenação entre os mecanismos de vigilância. Inicialmente, esta 
agência não teria poderes extensos, sendo somente um mecanismo de apoio à atuação dos Estados, sem capacidade de implementação autônoma de nenhuma medida. Esta proposta visava a evitar controvérsias com os Estados, o que fica claro no primeiro comunicado do Conselho sobre este assunto, no qual consta que: "responsibility for the management of the external borders lies with the member states [...] the agency is only needed in order to organise and develop indispensable coordination of operational cooperation" (Conselho Europeu, 2003, p. 3).

A preocupação em não alijar os Estados de sua posição soberana no controle das fronteiras foi tamanha que o Parlamento Europeu considerou a proposta exageradamente intergovernamental para lidar com temas que já eram tratados, em parte, segundo a lógica supranacional (Hobolth, 2006). Os deputados propuseram algumas mudanças nos dispositivos para a criação da Frontex, defendendo uma maior participação da Comissão ${ }^{190}$ e do próprio Parlamento ${ }^{191}$.

A criação da Frontex previa que esta agência teria independência em questões técnicas, como a formulação de relatórios, mapeamento de riscos e produção de dados sobre as rotas de imigração e fragilidades nos mecanismos nacionais de controle. Segundo a Comissão, a criação e a independência desta agência eram importantes, pois:

"[...] the Agency will be in a better position than even the Commission itself to accumulate the highly technical know-how on control and surveillance of the external borders that will be necessary, if the Agency shall give an added value to the operational co-operation in its field" (Comissão Europeia, 2003, p. 7).

A análise dos papéis desempenhados pelos Estados membros e pelas instituições europeias, no entanto, não deve ficar limitado ao Parlamento Europeu, à Comissão e aos políticos nacionais. É fundamental que seja compreendida a disputa que se deu neste momento entre diferentes projetos para a segurança das

\footnotetext{
${ }^{190}$ Foi sugerido que a diretoria da agência fosse formada por doze especialistas, sendo uma metade indicada pelos Estados e a outra pela Comissão. Além disso, o diretor deveria ser escolhido pela Comissão (Parlamento Europeu, 2004).

${ }^{191}$ Após analisar o documento preparado por Vitorino, muitos deputados constataram que o papel do Parlamento seria mínimo e exigiram que houvesse mecanismos mais claros e abrangentes para o controle político da atuação desta agência (Parlamento Europeu, 2004).
} 
fronteiras comuns. Participaram ativamente desta disputa os guardas de fronteiras, agentes alfandegários, membros das forças nacionais e gendarmeries. Estes competiam por influência sobre a definição do marco legal no qual a Frontex trabalharia, sobre a sua real necessidade, escopo de atuação e, finalmente, sobre quem deveria liderar esta nova agência. Havia somente um ponto de consenso entre os profissionais de segurança, o diretor da instituição deveria ser alguém com experiência no ramo e, principalmente, que mantivesse o foco no caráter operacional da agência (Hobolth, 2006). Assim, é possível compreender o que levou o currículo do general Laitinen a se destacar.

A lógica por trás da criação da Frontex não era de garantir uma vigilância fisicamente ostensiva nas fronteiras, mas sim controlar a entrada de todos os indivíduos de forma eficiente e uniforme sem que esta prática causasse desconforto aos mesmos. Em outras palavras, o objetivo era que a Frontex fosse capaz de estabelecer formas mais inteligentes de triagem de grupos populacionais, permitindo a entrada dos turistas e imigrantes legais com o mínimo possível de barreiras e a efetiva identificação dos indivíduos com um perfil ameaçador. Assim, no mandato aprovado, previa-se que:

"Frontex is to facilitate and render more effective the application of existing and future Community measures relating to the management of external borders. Frontex shall do so by ensuring the coordination of Member States' actions in the implementation of those measures, thereby contribution to an efficient, high and uniform level of control on persons and surveillance of the external borders of the Member States." (Conselho Europeu, 2004, p. 10)

Conforme visto, nos meses que se seguiram aos atentados nos EUA as instituições europeias proferiram discursos e debateram legislações que tinham como base a securitização da imigração na Europa e, portanto, a necessidade de políticas emergenciais para o controle de fronteiras. No entanto, ao contrário do que esperaria a Escola de Copenhague, não há um momento de exceção e o que se segue nos anos de 2002 e 2003 é uma negociação sobre melhores mecanismos de controle para as fronteiras, de divisão de responsabilidades e acomodação de interesses. Nesse sentido, mesmo o conselho de Laeken, de dezembro de 2001, 
não foi capaz de aprovar nenhuma inovação em termos de políticas de segurança das fronteiras comuns. Embora os Estados membros já debatessem sobre a necessidade de uma guarda europeia, as conclusões do conselho demonstram que os representantes dos países da UE preferiam não se comprometer com práticas assertivas neste campo. Deste modo, constatou-se a importância do gerenciamento integrado de fronteiras, mas optou-se apenas por instar os Estados a cooperarem de forma mais ampla na construção de mecanismos comuns de controle (House of the Lords, 2003).

A Frontex responde às questões apresentadas pelo Acordo de Schengen, no qual a eliminação dos controles para circulação no espaço interno já era vista como uma inovação que só poderia funcionar se aliada a maior vigilância das fronteiras externas. Trata-se da solução encontrada para a cooperação nesta área, "which is a necessary corollary to the free movement of persons within the European Union and a fundamental component if an area of freedom, security and justice" (Conselho Europeu, 2004, p. 4). Portanto, a tensão presente em Schengen sobre controle e mobilidade é reproduzida na criação da Frontex, sendo esta responsável por ajudar na separação e categorização de estrangeiros desejados e indesejados.

As contribuições de Foucault foram incorporadas à pesquisa, pois é a partir de sua leitura sobre o conceito de "governamentabilidade" que a Escola de Paris desenvolve as críticas ao estado da arte no campo de estudos de segurança. A prática de governo, para Foucault, é uma forma de constranger, formatar, guiar e/ou afetar a conduta dos indivíduos (Foucault, 2008). Esta atividade se dá através de estratégias para a disciplinarização, que incluem desde mecanismos policiais de controle até meios mais sutis que os levam a adotar determinado comportamento sem que a coerção seja necessária. Esta abordagem mais sutil é também uma "tecnologia de governo", mas sua aplicação se dá de forma a possibilitar que o governo opere sem que haja uma percepção radical acerca dos mecanismos pelos quais as relações de poder se impõem. Para compreender a "governamentabilidade", Foucault propõe a análise de três dimensões: (1) quem governa, direcionada para a definição variável de responsabilidades (dependendo do tema em questão, os atores com autoridade são diferentes); (2) o que deve ser governado, no caso a imigração; (3) e como as pessoas devem ser governadas, que implica também na forma como as identidades são construídas. Ou seja, “At stake 
is how governing is to be done, who should be subjected to it and who has the authority to settle these questions" (Hobolth, 2006, p. 4).

Esta abordagem, assim como as leituras de Bourdieu, enfatiza a análise empírica das disputas de poder justamente pelas tecnologias de governo. Estas não ocorrem em reuniões palacianas ou a partir de eleições gerais, mas sim nas relações entre profissionais da segurança. Esta mudança metodológica é defendida por Foucault, pois, segundo o autor, os discursos de líderes influentes são apenas formalizações de argumentos produzidos em outros níveis, são a constatação da vitória de determinados projetos em batalhas burocráticas, que se dão na rotina do trabalho do Estado.

Este conhecimento técnico, detentor de enorme poder simbólico, no entando, é motivo de grandes disputas entre os profissionais da segurança. Algumas vozes da própria UE, por exemplo, reconhecem que os imigrantes não são o principal vetor de risco no que tange ao terrorismo e chegam a afirmar que esta ameaça é sobrevalorizada pelos governos europeus ${ }^{192}$. Gilles de Kerchove, Coordenador de Políticas de Combate ao Terrorismo da UE, em entrevista à imprensa francesa afirmou que os serviços secretos tem tido sucesso em desmantelar grupos terroristas atuando no continente e que a maioria destes grupos era formada por indivíduos com cidadania europeia. Segundo Kerchove, os membros destes grupos são cooptados em grandes cidades do continente e fazem treinamentos em outros países, não sendo detectados pelos controles de fronteira, pois possuem passaportes europeus. A solução encontrada por Kerchove é tratar terroristas como criminosos comuns e utilizar os mecanismos extensivos de vigilância para identificá-los. Ou seja, o principal estrategista da UE para combate ao terrorismo sugere práticas cotidianas para combater esta ameaça e reconhece que o controle de fronteiras não é a principal dimensão das políticas de contenção desta ameaça.

Estes argumentos vão ao encontro da abordagem para o processo de securitização conforme avançada por Bigo. Segundo este autor, a securitização

\footnotetext{
${ }^{192}$ Em entrevista à France 24h, Kerchove reforçou esta retórica afirmando que o número de cidadãos britânicos mortos por picadas de abelha entre 2002 e 2012 foi consideravelmente superior ao número de pessoas mortas por atentados terroristas no país.
} 
"[...] comes also from a range of administrative practices such as population profiling, risk assessment, statistical calculation, category creation, proactive preparation and what may be termed as specific habitus of the 'security professional' with it's ethos of secrecy and concern for the management of fear and unease" (Bigo, 2002, p. 74).

A incorporação destes elementos na pesquisa está baseada na percepção de que os "atores securitizantes" são também os profissionais especializados das agências de segurança. Apesar de esta mudança requerer uma abordagem mais compreensiva, considerando um grupo bem mais amplo de atores no contínuo de segurança, até a Escola de Copenhague concorda que, devido ao arranjo institucional único da UE, “[...] there are cases where a logic of security is at play, even though no securitizing discourse is uttered in the public sphere to justify it" (Buzan et al, 1998, p. 28). Assim sendo, Bigo (2002) e Huysmans (2006) tem muito a contribuir com os estudos críticos deste campo, lançando luz à face do prisma da segurança que permanece esquecida na maioria das análises.

Segundo Huysmans, asilo e imigração não são naturalmente definidos pela União Europeia como ameaças centrais. Estes fenômenos vieram a ser vistos através das lentes de segurança de forma suave, uma vez que a definição das ameaças e momentos de insegurança "emerges from discursively and institutionally modulating practices in terms of security rationality that makes policies intelligible as a security practice" (Huysmans, 2006b, p. 12). Assim, para o autor, a relação destas questões com a temática da segurança

"[comes] from the context within which it is embedded rather then from the act of threat definition as such. Thus, even when not directly spoken off as a threat, asylum [and migration] can be rendered as security question[s] by being institutionally and discursively integrated in policy frameworks that emphasizes policing and defence" (Huysmans, 2006, p. 4).

Pode-se perceber que estas duas terminologias (asilo e imigração) já eram ligadas a iniciativas de policiamento de fronteiras e temas de segurança pública pelo Acordo de Schengen, o que aponta para a forma pela qual elas vieram a ser entendidas como ameaças. Portanto, para Huysmans, a criação da Frontex apenas reforça a transferência de insegurança para os diversos âmbitos da sociedade. 
Mesmo nos Estados Unidos, onde há mais evidências empíricas para argumentar que os atos de 11 de setembro foram seguidos por uma articulação de ameaças existenciais com discursos de emergência e a necessidade de respostas excepcionais - um exemplo do processo de securitização conforme definido por Wæver e Buzan -, uma coisa não mudou: "The routines, the hardware, the credibility of politically linking terrorism and asylum, an ongoing competition between intelligence agencies and the Pentagon [...] are embedded in long-term institutional and political histories and are enacted in everyday, ordinary practice" (Huysmans, 2006 p. 5) A implementação de instrumentos administrativos e a história institucional das agências envolvidas, bem como a competição entre elas, tem um impacto significativo no trabalho de construção de significados.

Isso não quer dizer que Huysmans e Bigo estejam totalmente distantes dos estudos de "securitização" que tendem a focar nos discursos mais visíveis de representantes do governo e membros do parlamento. Estes autores consideram que, em algumas raras ocasiões, o arcabouço analítico de Wæver e Buzan pode realmente explicar os processos sociais, mas estão mais preocupados com as longas dinâmicas de articulação de significados de segurança. Portanto, foca-se nos "professionals who gain their legitimacy of and power over defining policy problem from trained skills and knowledge and from continuous using these in their work" (Huysmans, 2006, p. 9) A lógica do contínuo de segurança com a qual estes autores trabalham ocorre de forma menos visível pelo público ou até em competições secretas de interesses entre os diferentes grupos de profissionais.

A Escola de Paris promove, portanto, uma mudança de foco nos estudos de segurança, deixando de se pautar somente nas ameaças e passando a observar as técnicas de articulação de significados e as estratégias discursivas pelas quais as práticas de governo constituem as relações sociais a partir da insegurança. A perspectiva aqui avançada tem como principal contribuição uma melhor compreensão empírica da forma pela qual o poder se organiza e se dissemina no campo das políticas de imigração. Destacando os modos de padronização, aferição, troca de experiência e avaliação de desempenho, esta escola apresenta uma leitura alternativa para o campo, que traça as origens do poder simbólico dos agentes públicos e privados (Aradau \& van Munster, 2007). Seu caráter normativo está no projeto que privilegia a diversidade como marca do ambiente político. $\mathrm{Ou}$ 
seja, o que move este grupo de autores é uma agenda de pesquisa que denuncia e desnaturaliza formas dominantes e excludentes de governo (C.A.S.E Collective, 2006).

Assim, estes autores propõem outras ferramentas metodológicas e abordagens éticas nas análises de fenômenos sociais. De acordo com Bigo e Huysmans, não é suficiente abranger uma perspectiva construtivista sobre segurança, referindo-se a um contínuo que pode mudar dadas as interpretações fluidas. Apesar de a Escola de Copenhague se apresentar como uma teoria crítica dos estudos deste campo, ela não aborda as principais consequências de se trabalhar com o jargão da exceção e a terminologia da ameaça. Nesse sentido, a contribuição de Buzan e Wæver acerca da análise de discurso é ofuscada por suas limitações empíricas e pelos resultados políticos de sua teoria.

Conforme argumentam Léonard (2011), Neal (2009), Boswell (2007a), Huysmans (2000; 2006) e Bigo (2002, 2008, 2010a), não faz sentido, na maioria dos casos, falar em securitização. O largo uso do quadro analítico da Escola de Copenhague, com foco em momentos de descontinuidade, se dá de forma pouco atenta e, muitas vezes, sem bases empíricas. Em geral, os mecanismos de articulação entre um dado fenômeno e os significados de segurança ocorrem através de práticas diárias, no âmbito das políticas normais, não sendo perpetrados por "grandes atores", mas sim por aqueles dispostos centralmente no aparato de segurança do Estado, os profissionais das agências especializadas. Afinal, "security is what the professionals of unease management make of it ${ }^{193}$ " (Bigo, 2002, p. 85). O processo de securitização não se desenvolve por rupturas, mas, ao contrário, trata-se simplesmente da continuidade da dinâmica política.

Indo além, para Bigo:

"Securitization is not usefully characterized as a discursive practice creating 'exceptionalization', even though it may find its origins in this practice. [...] Securitization works through everyday technologies, through the effects of power that are continuous rather than exceptional, through political struggles, and especially though institutional competition

\footnotetext{
${ }^{193}$ Bigo faz um jogo de palavras com a famosa hipótese de Alexander Wendt acerca do papel dos Estados na construção da anarquia internacional: "Anarchy is what states make of it" (Wendt, 1992).
} 
within the professional security field in which the most trivial interests are at stake" (Bigo, 2002, p. 73).

Assim, a compreensão do processo de articulação das políticas de imigração e de segurança na Europa requer uma perspectiva metodológica radicalmente distinta, focada no amplo ambiente social no qual a Frontex se tornou uma alternativa política viável. Consequentemente, a questão central não deve ser acerca do momento de criação desta agência, mas sim como se tornou possível para os governos europeus lidarem com imigrantes sob a ótica da (in)segurança.

Esta redefenição do projeto de pesquisa leva para a dimensão ética da crítica aqui apresentada, que se refere ao conceito de política implícito na teoria de securitização. Ao se pautar nas perspectivas de Schmitt para o ambiente político, o trabalho de Buzan e Wæver contibui para surgimento de uma

\begin{abstract}
“[...] 'war-based polity', a condition of generalized confrontation that is no longer able to distinguish between private and public enemies. Because it is based on claims about the need for survival at any price, on a real and permanent struggle anchored in a eschatology of the worst kind, it generates a distress policy, a misgiving policy, that transforms any change and any risk into an intentional threat or enemy" (Bigo, 2002, p. 81).
\end{abstract}

Trata-se de uma concepção na qual a divisão entre espaços políticos e de segurança - que poderiam, por ventura, se unir através dos processos de securitização - não existe. Ambos vieram a construir uma prática permanente de governo baseada em tecnologia (busca por eficiência) e preocupações de segurança. Deste modo, não há uma fronteira entre a formulação de políticas "normais" e "urgentes/excepcionais", elas são misturadas (homogêneas), formando uma sociedade do risco, na qual o foco não é na resposta às ameaças, mas sim a necessidade de antecipação. O objeto da segurança deixa de ser o ato em si, para dar lugar à potencialidade de ação. Desta forma, não faz sentido falar em termos de "securitização", já que o contexto não é de radicalização das políticas regulares, mas de uma ligação permanente entre fenômenos sociais e significados de segurança, que criam as condições para lidar com imigração e 
asilo a partir das mesmas ferramentas usadas para enfrentar o terrorismo ou crime organizado.

Há, portanto, uma proposta de mudança de rumo fundamental para a teoria política, que renega o legado de Schmitt (e, em última análise, o de Thomas Hobbes) e denuncia a violência do ambiente interno que, supostamente, seria o domínio da segurança. Argumentos sobre soberania e anarquia, para a Escola de Paris, servem para mascarar a brutalidade da ação estatal, que, através de suas rotinas burocráticas, é capaz de subordinar, excluir e sacrificar os indivíduos.

Assim, a sociologia política internacional traz uma importante contribuição para o debate no campo dos estudos de segurança. Baseado nos argumentos de Bigo e Huysmans é possível levar à luz algumas faces controversas da Frontex, compreendendo-a como um dos elementos do aparato da União Europeia que reflete as demandas de uma sociedade do risco, consolidando práticas nefastas de governo em que a exclusão torna-se o padrão. Para que um grupo seja "livre" e "seguro", milhões são excluídos, tendo de conviver com a face violenta da área de liberdade, segurança e justiça. 


\section{Referências bibliográficas}

ACORDO DE SCHENGEN. Convenção para Implementação do Acordo de Schengen. Schengen, $1985 . \quad$ Disponível em: http://eurlex.europa.eu/LexUriServ/LexUriServ.do?uri=CELEX:42000A0922(02):en:HTM L. Acesso em: 21 de maio, 2012.

ACTOR NETWORK TEXT ANALYSER PROJECT (ANTA). 2011. Disponível em: http://jiminy.medialab.sciences-po.fr/labs/frontex-scriper/. Acesso em: 09 de jul. 2012.

ADLER, E.; BARNETT, M. Security Communities. Cambridge: Cambridge University Press, 1998. 471p.

AGAMBEN, Giorgio. (1995). Homo Sacer: Sovereign Power and Bare Life. Stanford: Stanford University Press, 1998.

Estado de Exceção. São Paulo: Editora Boitempo, 2004.

ALDRICH, R. J. Transatlantic intelligence and security cooperation. International Affairs, v. 80, n. 4, p. 731-753, jul. 2004.

ALLISON, G.; ZELIKOW, P. Essence of Decision: Explaining the Cuban Missile Crisis. Boston: Little, Brown and Company, 1971. 416p.

ALTO COMISSARIADO DAS NAÇÕES UNIDAS PARA REFUGIADOS. Global Report, 2010. Disponível em: http://www.unhcr.org/gr10/index.html\#/home. Acesso em: 09 de jul. 2012.

ARADAU, C. Security and the democratic scene: desecuritization and emancipation. Journal of International Relations and Development, v. 7, n. 4, p. 388-413, Dez. 2004.

ARADAU, C; van MUNSTER, R. Governing terrorism through risk: Taking precautions, (un)knowing the future. European Journal of International Relations, v. 13, n. 1, p. 89-115, 2007.

Insuring Terrorism, Assuring Subjects, Ensuring Normality: The Politics of Risk After 9/11. Alternatives: Global, Local, Political, v. 33, n. 2, p. 191-210, 2008.

ARCHICK, K. U.S.-EU Cooperation Against Terrorism. Congressional Research Service, CRS Report for Congress, 21 de maio de 2012. Disponível em http://www.fas.org/sgp/crs/row/RS22030.pdf. Acesso em: 27 de ago. 2012.

ARENDT, H. (1949). Origens do Totalitarismo: Anti-semitismo, Imperialismo, Totalitarismo. São Paulo: Companhia das Letras, 2007. 569p. 
ARMITAGE Jr., D. T. US and EU Efforts to Fight Terrorism: Same Ends, Different Means - Or Same Means, Different Ends? In: EUROPEAN UNION STUDIES ASSOCIATION CONFERENCE, 2007. Montreal. Disponível em http://aei.pitt.edu/7683/1/armitage-d-04a.pdf. Acesso em: 27 de ago. 2012.

ASHLEY, R. The achievements of post-structuralism. In: SMITH, S. et al (Eds.). International Theory: positivism and beyond. Cambridge: Cambridge University Press, p. 240-253, 1996.

AYOOB, M. The Third World Security Predicament: state making, regional conflict, and the international system. Boulder: Lynne Rienner, 1995. 230p.

BALZACQ, T. The Three Faces of Securitization: Political Agency, Audience and Context. European Journal of International Relations, v. 11, n. 2, p. 171$201,2005$.

The Policy Tools of Securitization: Information Exchange, EU Foreign and Interior Policies. Journal of Common Market Studies, v. 46, n.1, p. 75-100, 2008.

BBC NEWS. 1979: British ambassador assassinated in Holland. BBC News On This Day. Disponível em http://news.bbc.co.uk/onthisday/hi/dates/stories/march/22/newsid_2543000/25438 67.stm. Acesso em: 04 de set. 2012.

BEHNKE, A. Terrorising the Political: 9/11 within the Context of the Globalisation of Violence. Millennium: Journal of International Studies, v. 33, n. 2, p. 279-312, 2004.

BEHNKE, A.; BISHAI, L. War, Violence, and the Displacement of the Political. In: ODYSSEOS, L.; PETITO, F. (Eds.), The International Political Thought of Carl Schmitt. Terror, Liberal War and the Crisis of Global Order. Londres: Routledge, 2007, p. 107-123.

BERTOZZI, S. Schengen: Achievements and Challenges in Managing an Area Encompassing 3.6 million $\mathrm{km}^{2}$. Center for European Policy Studies, Working document, n.284, Fev. 2008a.

The Policy Tools of Securitization: Information Exchange, EU Foreign and Interior Policies. Journal of Common Market Studies, v. 46, n.1, p. 75-100, 2008b.

BICCHI, F. The Union for the Mediterranean, or the Changing Context of EuroMediterranean Relations. Mediterranean Politics, v. 16, n. 1, p. 3-19, mar. 2011.

BIGO, D. The European Internal Security Field: Stakes and Rivalries in a Newly Developing Area of Police Intervention. In: ANDERSON, M.; den BOER, M. (Eds.), Policing across National Boundaries. Londres: Pinter Publishers, 1994. p. 161-173. 
- Security and Immigration: Toward a Critique of the Governmentality of Unease. Alternatives, n. 27, Special Issue, p. 63-92, 2002.

. Liberty, whose liberty? The Hague Programme and the conception of freedom. CHALLENGE Project: Liberty \& Security, 2005. Disponível em: http://www.libertysecurity.org/article339.html. Acesso: em 06 de jul. 2012.

International Political Sociology. In: WILLIAMS, P. (Org.). Security Studies: An Introduction. Londres: Routledge, 2008a. p. 116-129.

. Security: A Field Left Fallow. In: DILLON, M; NEAL, A. (Eds.). Foucault on Politics, Security and War. Londres: Palgrave Macmillan, 2008b. p. 93-114.

Globalized (in)security: The field and the ban-opticon. In: BIGO, D; TSOUKALA, A. (Eds.). Terror, Insecurity and Liberty: Illiberal practices of liberal regimes after 9/11. Londres: Routledge, 2008c, p. 10-48.

Immigration controls and free movement in Europe. International Review of the Red Cross, v. 91, n. 875, Set. 2009.

. Delivering Liberty and Security? The Reframing of Freedom When Associated with Security. In: BIGO, D. et al. Europe's $21^{\text {st }}$ Century Challenge: Delivering Liberty. Londres: Ashgate, 2010a.

- September 14, 2001: the regression to the habitus. In: DEL LAGO, A.; PALLIDA, S. Conflict, Security and the Reshaping of Society: The Civilisation of War. Abingdon: Routledge, 2010b.

Freedom and Speed in Enlarged Borderzones. In: SQUIRE, V (Ed.). The Contested Politics of Mobility: Borderzones and Irregularity. Londres: Routledge, 2010c.

Pierre Bourdieu and International Relations: Power of Practices, Practices of Power. International Political Sociology, n. 5, p. 225-258, 2011.

.; WALKER, R.B.J. Global Counter-Terrorism: From war to the widespread surveillance. In: FERNÁNDEZ, G. R. et al (Eds.). Warlike Outlines of the Securitarian State: Life Control and the Exclusion of People. CHALLENGE Project: Liberty \& Security, 2009. Disponível em: http://repositori.udl.cat/bitstream/10459.1/336/1/07249_247372_386_.pdf. Acesso em: 07 de jul. 2012.

BILGIC, A. Securitization of Immigration and Asylum: A Critical Look at Security Estructure in Europe. 2006. 42p. Dissertação (Mestrado em Estudos Europeus) - Departamento de Ciência Política, Universidade de Lund, Lund. 2006.

BILGIN, P. Critical Theory. In: WILliAMS, P. (Ed.). Security Studies: An Introduction. Londres: Routledge, 2008. p. 89-102. 
The Securityness of Secularism? The Case of Turkey. Security Dialogue, Oslo, v. 39, n. 6, p. 593-614, dez. 2008.

BONELLI, L. 'Hidden in plain sight': intelligence, exception and suspicion after 11 september 2001. In: BIGO, D; TSOUKALA, A. (Eds.). Terror, Insecurity and Liberty: Illiberal practices of liberal regimes after 9/11. Londres: Routledge, 2008, p. 100-120.

BOOTH, K; TIENDA, M. Gender, Migration and Social Change. International Sociology. v. 6, n. 1, pp. 51-72, mar. 1991.

BOOTH, K. Security and emancipation. Review of International Studies, Londres, n. 17, p. 313-326, 1991.

. (Ed.). Critical Security Studies and World Politics. Boulder: Lynne Rienner Publisher, 2005. 336p.

BOSWELL, C. The Securitisation of Migration: A Risky Strategy for European States. Danish Institute for International Studies, DIIS Brief, Abr. 2007a.

Migration Control in Europe after 9/11: Explaining the Absence of Securitization. Journal of Common Market Studies, v. 45, n. 3, p. 589-610, $2007 b$.

BOURBEAU, P. The Securitization of Migration: A study of movement and order. Londres: Routledge, 2011. 166p.

BOURDIEU, P. Distinction: A Social Critique of the Judgement of Taste. Londres: Routledge, 1984. 610p.

The Forms of Capital. In: RICHARDSON, J. (Ed.). Handbook of Theory and Research for the Sociology of Education. New York: Greenwood, 1986, p. 241-258.

Press, 1990. 337p.

(1980). The Logic of Practice. Stanford: Stanford University

O Poder Simbólico. Rio de Janeiro: Bertrand Brasil, 2001. 322p.

BOURDIEU, P; WACQUANT, L. An Invitation to Reflexive Sociology. Chicago: Chicago University Press, 1992. 339p.

BRAHIMI, L. Report on the Panel on United Nations Peace Operations, Executive Summary and Recommendations, United Nations, Out. 2000. Disponível em: http://www.un.org/peace/reports/peace_operations/. Acesso em: 06 de jul. 2012.

BRESLER, F. Interpol: A history and examination of 70 years of crime solving. Londres: Sinclair-Stevenson, 1992, 256 p. 
BROWING, C. S.; MCDONALD, M. The Future of Critical Security Studies: Ethics and the Politics of Security. European Journal of International Relations, v.17, n.3, p.1-21, 2011.

BUNYAN, T. Trevi, Europol and the European state. Statewatching the new Europe, v. 1, 1993.

BURGESS, J.P. Security as Ethics. PRIO Publications, 2008. Policy Brief.

BUZAN, B. People, States and Fear: The National Security Problem in International Relations. Hempstead: Harvest Wheastsheaf, 1983. 262p.

People, States and Fear: An Agenda for International Security Studies in the Post-Cold War Era. Colorado: Lynne Rienner Publishers, 1991. $311 \mathrm{p}$.

Rethinking Security after the Cold War. Cooperation and Conflict, v. 32, n. 1, p. 5-28, mar. 1997.

BUZAN, B. et al. Security: A New Framework for Analysis. Londres: Lynne Rienner Publishers, 1998. 239p.

BUZAN, B.; HANSEN, L. The Evolution of International Security Studies. Cambridge: Cambridge University Press, 2009. 384p.

CALLOVI, G. Securing External Frontiers in a Union of 25. Migration Policy Institute, Washington, Policy Brief No. 5, set. 2004.

CARR, E. H. Vinte anos de Crise 1919-1939. Brasília: Editora UNB, 1939. (impressão 2001). 356p.

CARRERA, S. The EU Border Management Strategy: FRONTEX and the Challenges of Irregular Immigration in the Canary Islands. Center for European Policy Studies, Bruxelas, n. 261, mar. 2007. CEPS Working Document.

CARRERA, S.; GEYER, F. Terrorism, Borders and Migration: The Commission's 2008 Policy Strategy in the Area of Freedom, Security and Justice. Center for European Policy Studies, Bruxelas, n. 131, Jun. 2007. CEPS Policy Briefs.

C.A.S.E. Collective. Critical Approaches to Security in Europe: A Networked Manifesto. Security Dialogue, Oslo, v.. 37, n. 4, p. 447-483, dez. 2006.

CARTA DE DIREITOS FUNDAMENTAIS DA UNIÃO EUROPEIA. Disponível em: http://www.europarl.europa.eu/charter/default_en.htm. Acesso em: 11 de jul. 2012.

CHIPMAN, J. The future of strategic studies: Beyond even grand strategy. Survival: Global Politics and Strategy, v. 34, n. 1, p. 109-131, 1992. 
CIUTA, F. Conceptual Notes on Energy Security: Total or Banal Security? Security Dialogue, Oslo, v. 41, n. 2, p. 123-144, abr. 2010.

CLOCHARD, O. The Death at the EU Border Map. In: HUYSMANS, J; REGAZZI, F. (Eds.). Liberty \& Security: Multi-media Teaching and Training Module. Challenge, 2009. Disponsível em: http://www.libertysecurity.org/module/. Acesso em: 11 de nov. 2011.

COLLINS, A. Contemporary Security Studies. Oxford: Oxford University Press, 2007. 444p.

COMISSÃO DAS COMUNIDADES EUROPEIAS. Communication from the Commission to the Council and the European Parliament on a Common Policy on Illegal Immigration. COM(2001)672 final. Bruxelas, 15 de Nov. 2001. Disponível em: lex.europa.eu/LexUriServ/LexUriServ.do?uri=COM:2001:0672:FIN:EN:PDF. Acesso em: 08 de jul. 2012.

Towards integrated management of the external borders of the member states of the European Union. COM (2002) 233 final, Bruxelas, 7 de maio de 2002. Disponível em: http://eurlex.europa.eu/LexUriServ/LexUriServ.do?uri=COM:2002:0233:FIN:EN:PDF. Acesso em: 28 de set. 2012.

- The operating framework for the European Regulatory Agencies. COM(2002) 718 final, Bruxelas, 11 de dez. 2002. Disponível em: http://ec.europa.eu/governance/docs/comm_agence_en.pdf. Acesso em: 16 de maio. 2012.

"Proposal for a Council Regulation establishing a European Agency for the Management of Operational Co-operation at the External Borders". COM/2003/0687 final - CNS 2003/0273. Brussels, 20 November, 2003. Disponível em: http://eurlex.europa.eu/LexUriServ/LexUriServ.do?uri=CELEX:52003PC0687:EN:HTML. Acesso em: 05 de jul. 2012.

European Commission Action Paper in response to the terrorist attacks on Madrid. Memo/04/66, Bruxelas, 18 de março de 2004. Disponível em http://europa.eu/rapid/pressReleasesAction.do?reference=MEMO/04/66\&format= HTML\&aged $=0 \&$ language $=E N \&$ guiLanguage $=e n$. Acesso em: 26 de ago. 2012 .

. The Global Approach to Migration one year on: Towards a comprehensive European migration policy. COM(2006) 375 final, Bruxelas, 30 de novembro de 2006. Disponível em: http://www.statewatch.org/news/2006/dec/eucom-735-2006-migration.pdf. Acesso em: 19 de maio 2012.

Report on the evaluation and future development of the FRONTEX agency, Bruxelas, COM(2008) 67 final, 13 de fevereiro de 2008. 
Disponível

em

http://eur-

lex.europa.eu/Notice.do?mode=dbl\&lang=en\&ihmlang=en\&lng1=en,pt\&lng2=bg ,cs,da,de,el,en,es,et,fi,fr,hu,it,lt,lv,mt,nl,pl,pt,ro,sk,sl,sv,\&val=464860:cs\&page=.

Acesso em 28 de set. 2012.

COMISSÃO EUROPEIA. The relationship between safeguarding internal security and complying with international protection obligations and instruments. Commission Working Document $\operatorname{COM}(2001) 743$ final. Bruxelas: 2001. Disponível em http://eurlex.europa.eu/LexUriServ/LexUriServ.do?uri=COM:2001:0743:FIN:EN:PDF. Acesso em: 12 de jul. 2012.

The development of a common policy on illegal immigration, smuggling and trafficking in human beings, external borders and the return of illegal residents. COM(2003) 323 final, Bruxelas, 3 de jun. 2003.

Action paper in response to the terrorist attacks on Madrid. MEMO/04/65, Bruxelas, 18 de março de 2004. Disponível em: www.statewatch.org/news/2004/mar/Comm-Action-Plan.pdf. Acesso em: 17 de jul. 2012.

Providing for sanctions against employers of illegally staying third-country nationals. Commission Staff Working Paper SEC(2007) 603, Bruxelas, 16 de maio. 2007.

Communication from the Commission to the European Parliament and the Council. Relatório Bianual sobre o Funcionamento da Área de Schengen: 1 de novembro de 2011 à 30 de abril de 2012. COM(2012) 230 final, Bruxelas: 16 de maio de 2012. Disponível em: http://www.statewatch.org/news/2012/may/eu-schengen-biannual-report-nov11apr12.pdf. Acesso em: 11 de jun. 2012.

CONSELHO DA EUROPA. European Convention on the Supression of Terrorism, Estrasburgo, 27 de janeiro de 1977. Disponível em: http://conventions.coe.int/Treaty/en/Treaties/Html/090.htm. Acesso em: $29 \mathrm{de}$ ago. 2012.

CONSELHO DA UNIÃO EUROPEIA. The Treaty of Amsterdam - Amending the Treaty on the European Union, the treaties establishing the European Communities and certain related acts. Jornal Oficial, C340, 10 de novembro de 1997. Disponível em: http://eurlex.europa.eu/en/treaties/dat/11997D/htm/11997D.html. Acesso em: 05 de jul. 2012.

. Presidency Conclusions of the Tampere Meeting. DOC/99/14. Brussels, 15 e 16 de outubro de 1999. Disponível em: http://europa.eu/rapid/pressReleasesAction.do?reference=DOC/99/14\&format=H TML\&aged=0\&language=EN\&guiLanguage=en. Acesso em: 09 de jul. 2012. 
. The Schengen Acquis. Bruxelas, 22 de setembro de 2000.

Disponível em:

http://eur-

lex.europa.eu/LexUriServ/LexUriServ.do?uri=OJ:L:2000:239:0001:0473:EN:PD

F. Acesso em: 09 de jul. 2012.

The Treaty of Nice - Amending the Treaty on the European Union, the treaties establishing the European Communities and certain related acts. 2001/C, 80/01. 10 de março de 2001. Disponível em: http://eurlex.europa.eu/en/treaties/dat/12001C/pdf/12001C_EN.pdf. Acesso em: 09 de jul. 2012.

Presidency Conclusions of the Laeken Meeting. SN300/1/01REV-1. Bruxelas, 14 e 15 de dezembro de 2001. Disponível em: http://ec.europa.eu/governance/impact/background/docs/laeken_concl_en.pdf. Acesso em: 09 de jul. 2012.

NOTA DA DELEGAÇÃO DO REINO UNIDO. United Kingdom delegation Strategic Committee on Immigration, Frontiers and Asylum Centre of Excellence at Dover - Mobile Detection Unit. 11994/02. Bruxelas, 13 de setembro de 2002. Disponível em: http://www.statewatch.org/news/2002/sep/11994.pdf. Acesso em: 09 de jun. 2012.

Council Regulation establishing the European Agency for the Management of Operational Cooperation at the External Borders of the Member States of the European Union. (EC) No 2007/2004. Bruxelas, 26 de outubro de 2004. Disponível em: http://eurlex.europa.eu/LexUriServ/LexUriServ.do?uri=OJ:L:2004:349:0001:0011:EN:PD F. Acesso em: 09 de jul. 2012.

. 2768th Council Meeting: Justice and Home Affairs - Press Release. No. 15801/06. Bruxelas, 4 e 5 de dezembro de 2006. Disponível em: http://ec.europa.eu/echo/civil_protection/civil/prote/pdfdocs/jha_council_041206. pdf. Acesso em: 09 de jul. 2012.

Updated EU Schengen Catalogue on External borders control, return and readmission. No. 7864/09. Bruxelas, 19 de março de 2009. Disponível em:

http://www.schengen.mira.gov.ro/English/Documente/utile/catutil/Updated\%20E U\%20Schengen\%20Catalogue.pdf. Acesso em: 09 de jul. 2012.

Strategic Committee on Immigration, Frontiers and Asylum Continuation until 1 January 2012 and re-evaluation by Coreper, 16072/09, POLGEN 188, ASIM 130, FRONT 100. Bruxelas: 16 de novembro de 2009. Disponível em: http://www.statewatch.org/news/2009/dec/eu-scifa-16072-09.pdf. Acesso em: 19 de mar. 2012.

CONSELHO DAS COMUNIDADES EUROPEIAS. Regulation on freedom of movement for workers within the Community. Comunidade Econômica Europeia, n. 1612/68, 15 de outubro de 1968. Disponível em: http://eur- 
lex.europa.eu/smartapi/cgi/sga_doc?smartapi!celexapi!prod!CELEXnumdoc\&lg= EN\&numdoc=31968R1612\&model=guichett. Acesso em: 25 de jun. 2012.

- Council resolution on an action programme for migrant workers and members of their families. Official Journal, C $034,14 / 02 / 1976$ P. $0002-0003,9$ de fevereiro de 1976. Disponível em http://legislationline.org/documents/action/popup/id/8677. Acesso em: 28 de set. 2012.

CONSELHO DE JUSTIÇA E ASSUNTOS INTERNOS. Conclusions adopted by the Council (Justice and Home Affairs). SN 3926/6/01-REV 6. Bruxelas, 20 de setembro de 2001. Disponível em: http://www.icclr.law.ubc.ca/Site\%20Map/compendium/Compendium/Declaration s/EU_conclusions_justice\%20and\%20homeaffairscouncil_2001.pdf. Acesso em: 09 de jul. 2012.

. Council Framework Decision on Combating Terrorism. 2002/475/JHA, OJ/L/164, 22 de junho de 2002. Disponível em; http://eurlex.europa.eu/LexUriServ/LexUriServ.do?uri=OJ:L:2002:164:0003:0003:EN:PD F. Acesso em: 09 de jul. 2012.

CONSELHO EUROPEU. Presidency Conclusions of the Nice European Council. 7-9 de dezembro de 2000. Disponível Em: http://www.consilium.europa.eu/uedocs/cms_data/docs/pressdata/en/ec/00400r1.\%20ann.en0.htm. Acesso em: 16 de maio. 2012.

. Council Common Position of 27 December 2001 on Combating Terrorism. 2001/931/CFSP, Bruxelas, 28 de dezembro de 2001. Disponível em: http://eur-

lex.europa.eu/LexUriServ/LexUriServ.do?uri=OJ:L:2001:344:0093:0096:EN:PD F. Acesso em: 14 de maio. 2012.

A Secure Europe in a Better World - European Security Strategy. Bruxelas, 12 de dezembro de 2003. Disponível em: http://www.consilium.europa.eu/uedocs/cmsUpload/78367.pdf. Acesso em: $12 \mathrm{de}$ set. 2012.

EU Action Plan on combating terrorism. Bruxelas, doc. 5771/1/06 REV 1, 13 de fevereiro de 2006. Disponível em http://www.statewatch.org/news/2006/feb/eu-terr-action-plan-feb-06.pdf. Acesso em: 11 de jul. 2012.

Disponível

Presidency conclusions, Bruxelas, 14 de fevereiro de 2008.

http://www.consilium.europa.eu/ueDocs/cms_Data/docs/pressData/en/ec/97669.p df. Acesso em: 10 de jul. 2012.

COWI. External Evaluation of the European Agency for the Management of Operational Cooperation at the External Borders of the Member states of the European Union. Relatório Final, Janeiro de 2009. Disponível em: 
http://www.statewatch.org/news/2009/may/frontex-eval-report-2009.pdf. Acesso em: 20 de jun. 2012.

DARIO, D. Didier Bigo e a Utilização da Sociologia de Bourdieu para Repensar a Segurança Internacional. Perspectiva Internacional, v. 1, n. 1, p. 4-15, 2009.

DEN BOER, M. 9/11 and the Europeanisation of Anti-terrorism Policy: A Critical Assessment. Groupement D'Études et de Recherches Notre Europe, Paris, n. 6, Set. 2003. Policy Papers.

DEPARTAMENTO DE ASSUNTOS ECONÔMICOS E SOCIAIS DAS NAÇÕES UNIDAS. Trends in International Migrant Stock: The 2008 Revision. (UN Database, POP/DB/MIG/STOCK/Rev.2008). Disponível em: http://www.un.org/esa/population/migration/UN_MigStock_2008.pdf. Acesso em: 17 de maio. 2012.

DER DERIAN, J; SHAPIRO, M. J. International/Intertextual Relations: PostModern Readings of World Politics. Lexington: Lexington Books, 1989. 353p.

DINAN, D. Ever Closer Union: An introduction to the European Community. Boulder: Lynne Rienner Publishers, 1994. 597p.

DONNELLY, J. Realism and International Relations. Cambridge: Cambridge University Press, 2000. 231p.

DUQUE, M. O Papel de Síntese da Escola de Copenhague nos Estudos de Segurança Internacional. Contexto Internacional, v. 31, n. 3, p. 459-501, set/ dez. 2009.

ECONOMIST, THE. Europe's far right: Culture matters more. The Economist [online], 11 de agosto de 2012. Disponível em: http://www.economist.com/node/21560194. Acesso em: 11 de ago. 2012.

EKELUND, H. Tracing the establishment of the European Agency for Management of Operational Cooperation at the External Borders (FRONTEX). In: ECPR Pan-European Conference on EU Politics, IV, 25 à 27 de setembro de 2008, Riga.

ENGENE, J. The Extreme Right in West European Terrorism. CONFERENCE ON THE EXTREME RIGHT IN NORWAY, 1., 2011, Aarhus. Disponível em http://cir.au.dk/fileadmin/site_files/filer_statskundskab/subsites/cir/pdffiler/The_Extreme_Right_in_West_European_TerrorismJAN_OSKAR_ENGENE .pdf. Acesso em: 09 de jul. 2012.

ERICKSON. C. Counter-Terror Culture: Ambiguity, Subversion, or Legitimization? Security Dialogue, Oslo, v. 38, n.2, p. 197-214, Jun. 2007.

ERIKSSON, J. Observes or Advocates? On the Political Role of Security Analysts. Cooperation and Conflict, v.34, n. 3, p. 311-330, 1993. 
ETTE, A.; FAIST, T. (Ed.). Between Autonomy and the European Union: The Europeanization of National Policies. Houndmills: Palgrave Macmillan, 2006. $273 p$.

EURACTIV. Brits ignore Baroness Ashton. EurActiv.com [online], Bruxelas, 07 de fevereiro de 2012a. Disponível em: http://www.euractiv.com/future-eu/britsignore-baroness-ashton-news-510615. Acesso em: 12 de mar. 2012.

. MEPs launch counterattack against Schengen deal. EurActiv.com

[online], Bruxelas, 13 de junho de 2012b. Disponível em: http://www.euractiv.com/justice/meps-launch-accuse-eu-ministers-news-513264. Acesso em: 13 de jun. 2012.

Greece to deport 1,600 in immigration crackdown. EurActiv.com [online], Bruxelas, 07 de agosto de 2012c. Disponível em: http://www.euractiv.com/migrations/greece-cracks-illegal-immigrants-news514241. Acesso em: 08 de ago. 2012.

Swiss view partnerships as a way to curb illegal migration. EurActiv.com [online], Bruxelas, 15 de outubro de 2012c. Disponível em: http://www.euractiv.com/migrations/swiss-partnerships-way-curb-ille-news515321. Acesso em: 15 de out. 2012.

EUROBARÔMETRO. Racism and xenophobia in Europe. Eurobarometer Opinion Poll, no. 47.1, DeZembro, 1997. Disponível em: http://ec.europa.eu/public_opinion/archives/ebs/ebs_113_en.pdf. Acesso em: 11 de maio. 2012.

Standard Eurobarometer 71: Public Opinion in the European Union. Comissão Europeia, TNS Opinion \& Social, Primavera, 2009. Disponível em: http://ec.europa.eu/public_opinion/archives/eb/eb71/eb71_std_part1.pdf. Acesso em: 19 de maio. 2012.

Comunicação da Comissão para o Parlamento Europeu, o Conselho, Comitê Econômico e Social Europeu e o Comitê de Regiões. Bruxelas, 2008. Report on the evaluation and future development of the FRONTEX agency. Disponível em http://eurlex.europa.eu/LexUriServ/LexUriServ.do?uri=COM:2008:0067:FIN:EN:PDF. Acesso em: 10 de jul. 2012.

EUROPOL. History. 2011. Disponível em: https://www.europol.europa.eu/content/page/history-149. Acesso em: $06 \mathrm{de}$ dez. 2011

EUROSTAT, 2009. Disponpivel em: http://epp.eurostat.ec.europa.eu/statistics_explained/index.php/Migration_and_mi grant_population_statistics. Acesso em: 09 de jul. 2012.

FERREIRA, L. V. A Securitização da Cooperação para o Controle de Fronteiras da União Europeia. Lex Humana, v. 3, n.2, p. 40-58, 2011. 
FIERKE, K. Critical Approaches to International Security. Cambridge: Polity, 2007. 235p.

FOUCAUlT, M. (1969). A Arqueologia do Saber. Rio de Janeiro: Editora Forense Universitária, 2008. 238 p.

Fontes, 2008. 572p.

Segurança, Território, População. São Paulo: Editora Martins

FRATTINI, F. Towards a Stronger European Immigration Policy. European View, v. 7, p. 35-40, 2007.

FRONTEX. Frontex Budget 2011, 2012. Disponível em: $\mathrm{http}$ ///frontex.europa.eu/assets/About_Frontex/Governance_documents/Budget/Bu dget_2011.pdf. Acesso em: 31 de mar. 2012.

. The Impact of the Global Economic Crisis on Illegal Migration to the EU. Risk Analysis Unit, Warsóvia, agosto de 2009. Disponível em: http://www.europarl.europa.eu/meetdocs/2009_2014/documents/libe/dv/frontex_ / frontex_en.pdf; Acesso em: 09 de jul. 2012.

Disponível

Annual Risk Analysis 2011. Varsóvia: Frontex, 2011. http://www.frontex.europa.eu/assets/Publications/Risk_Analysis/Annual_Risk_A nalysis_2011.pdf. Acesso em: 03 de abr. 2012.

Frontex General Report 2007. Disponível em: http://www.frontex.europa.eu/assets/About_Frontex/Governance_documents/Ann ual_report/2007/frontex_general_report_2007_final.pdf. Acesso em: 16 de maio. 2012.

Origin. Disponível em: http://www.frontex.europa.eu/about/origin. Acesso em: 10 de jul. 2012.

GAD, U.; PETERSEN, K. Concepts of politics in securitization studies. Security Dialogue, Oslo, v. 42, n. 4-5, p. 315-328, 2011.

GALLI, F. The Legal and Political Implications of the Securitisation of CounterTerrorism Measures across the Mediterranean. Euro-Mediterranean Study Commission, Bruxelas, setembro de 2008. EuroMesco Paper, No 71.

GALTUNG, J. Violence, Peace and Peace Research. Journal of Peace Research, v. 6, n. 3, pp. 167-191, 1969.

GARNETT, S. W. Keystone in the Arch: Ukraine in the Emerging Security Environment of Centraland Eastern Europe. Washington D.C.: Carnegie Endowment for International Peace, 1997. 145p. 
GEDDES, A. Immigration and European Integration: Towards fortress Europe? Manchester: Manchester University Press, 2000. 196p.

The politics of migration and immigration in Europe. Londres:

Sage Publications, 2003. 221p.

GERMAN MARSHALL FUND OF THE US. Transatlantic Trends: Immigration 2010. Washington DC: GMFUS, 2011. Disponível em: http://trends.gmfus.org/immigration/doc/TTI2010_English_Key.pdf. Acesso em: 12 de maio. 2012.

GUILD, E. The Uses and Abuses of Counter-Terrorism Policies in Europe: The Case of the 'Terrorists List'. Journal of Common Market Studies, v. 46, n. 1, p. 173-193, 2008.

. Security and Migration in the 21st Century. Polity Press: Cambridge, 2009. 218p.

GUIRAUDON, V. Seeking new venues: The Europeanization of migrationrelated policies. Swiss Political Science Review, v. 7, n. 3, p. 101-107, 2001.

HANSEN, L. The Little Mermaid's Silent Security Dilemma and the Absence of Gender in the Copenhagen School. Millennium, v. 29, n. 2, p. 285-306, 2000.

HALLIDAY, F. The making of the second cold war. Londres: Verso Books, 1989. 292p.

HOBBING, P. The management of the EU's external borders: From the Customs Union to Frontex and e-borders. In: CARRERA, S; EGGENSCHWILER, A.; GUILD, E. (Eds.). The Area of Freedom, Security and Justice Ten Years on: Success and Future Challenges under the Stockholm Programme. Bruxelas: CEPS, 2010, p.73-82.

Integrated Border Management at the EU Level. Center for European Policy Studies, Bruxelas, n.227, Agosto de 2005. CEPS working Document.

HOBOLTH, M. Governing the borders of Europe: the establishment of the Frontex agency. SECURITY, TECHNOLOGY AND BORDERS: EU RESPONSES TO NEW CHALLENGES. Bruxelas, 7 de out. 2006.

HOOGENSEN, G.; ROTTEM, S. Gender Identity and Subject of Security. Security Dialogue, Oslo, v. 35, n. 2, p. 155-171, Jun. 2004.

HOUSE OF THE LORDS European Union - Twenty-Ninth Report. Londres, 2003. Disponível em: http://www.parliament.the-stationeryoffice.co.uk/pa/ld200203/ldselect/ldeucom/133/13301.htm. Acesso em: 14 de out. 2012. 
Frontex: the EU external borders agency. European Union Committee - Ninth Report of Session 2007-08. Report with evidence, Londres, mar. 2008.

HUMAN RIGHTS WATCH. The EU's Dirty Hands: Frontex Involvement in IllTreatment of Migrant Detainees in Greece. Human Rights Watch, Setembro, 2011.

HUYSMANS, J. The Question of the limit: Desecuritisation and the Aesthetics of Horror in Political Realism. Millennium, v. 27, n.3, p. 569-589, 1998a.

Revisiting Copenhagen. European Journal of International

Relations, v.4, n.4, p.479-504, 1998 b.

The European Union and the Securitization of Migration.

Journal of Common Market Studies, v. 38, n.5, p. 751-777, 2000.

The Politics of Insecurity: Fear, migration and asylum in the EU. New York: Rutledge, 2006a. 191p.

International Politics of Insecurity: Normativity, Inwardness

and the Exception. Security Dialogue, Oslo, v. 37, n. 1, p. 11-29, $2006 \mathrm{~b}$.

The Jargon of Exception: On Schmitt, Agamben and the Absence of Political Society. International Political Sociology, v. 2, n. 2, p. 165-183, 2008.

INTERNATIONAL ORGANIZATION FOR MIGRATION. World Migration. Annual Report, Genebra, 2003. Relatório anual. Disponível em: http://publications.iom.int/bookstore/free/WMR_2010_ENGLISH.pdf. Acesso em: 10 de jul. 2012.

IRELAND, P. Facing the True 'Fortress Europe': Immigrants and Politics in the EC. Journal of Common Market Studies, v. 29, n. 5, p. 457-480, 1991.

JACKSON, N. International Organizations, Security Dichotomies and the Trafficking of Persons and Narcotics in Post-Soviet Central Asia: A Critique of the Securitization Framework. Security Dialogue, Oslo, v. 37, n. 3, p. 299-317, Set. 2006.

JEANDESBOZ, J. Reinforcing the Surveillance of the EU Borders: The Future Development of FRONTEX \& EUROSUR. CHALLENGE Project: Liberty \& Security, n. 11, Agosto de 2008. Research Paper.

JERVIS, R. Cooperation Under the Security Dilemma. World Politics, v. 30, n. 2, p. 167-214, 1978.

JORRY, H. Construction of a European Institutional Model for Managing Operational Cooperation at the EU's External Borders: Is the FRONTEX Agency 
a decisive step forward? CHALLENGE Project: Liberty \& Security, n. 6, Março de 2007. Research Paper.

JUTILA, M. Desecuritizing Minority Rights: Against Determinism. Security Dialogue, Oslo, v. 37, n. 2, June, p. 167-185, 2006.

KARYOTIS. G. European Migration Policy in the Aftermath of September 11th: The security-migration nexus. Innovation: The European Journal of Social Science Research, v. 20, n.1, p. 1-17, 2007.

KATZENSTEIN, P. J (Org.). The Culture of National Security: Norms and identities in world politics. Nova York: Columbia University Press, 1996. 436p.

et al. International Organization and the Study of World

Politics. International Organization, v.. 52, n. 4, p. 645-685, 1998.

KELLER, S. et al. Frontex Agency: Which Guarantees for Human Rights? Migreurop, Bruxelas, março de 2011. Disponível em: http://www.migreurop.org/IMG/pdf/Frontex-PE-Mig-ENG.pdf. Acessado em: 10 de maio. 2012.

KELSEN, H. (1960) Teoria Pura do Direito. São Paulo: Editora Martins Fontes, 2003.

KEOHANE, R. After Hegemony: Cooperation and Discord in the World Political Economy. Princeton: Princeton University Press, 1984. 290p.

International Institutions: Two Approaches. International Studies Quarterly, v. 32, n. 4, p. 379-396, Dezembro de 1988.

KEOHANE, R.; NYE, J. Transnational Relations and World Politics. Massachusetts: Harvard University Press, 1972. 428p.

Power and Interdependence: World Politics in Transition. Boston: Brown, Little and Company, 1977. 273p.

de KERCHOVE, G. Speech delivered for the 10th Anniversary of EUROJUST. Disponível em http://www.consilium.europa.eu/media/1459936/speech-10th-aneurojust-ver2.pdf. Acesso em: 12 de out. 2012.

KESSLER, O. Beyond sectors, before the world: Finance, security and risk. Security Dialogue, v.42, n.2, p. 197-215, abr. 2011.

KICINGER, A. International Migration as a Non-Traditional Security Threat and the EU Responses to This Phenomenon. Central European Forum For Migration Research, n.2, 2004. CEFMR Working Paper.

KOWERT, P. Toward a Constructivist Theory of Foreign Policy. In: KUBAlKova, V.; PETTMAn, R. (Eds.) Foreign Policy in a Constructed World. Armonk: M. E. Sharpe, 2001, p. 266-287. 
KRALER, A.; ROGOZ, M. Irregular Migration in the European Union since the turn of the millennium - development, economic background and discourses. Database on Irregular Migration, n.10, 2011. Working paper. Disponível em: http://irregular-migration.net/. Acesso em: 07 de jul. 2012.

KRAUSE, K.; WILLIAMS, M. Broadening the Agenda of Security Studies: Politics and Methods. Mershon International Studies Review, v. 40, n.2, p. 229 254, 1996.

(Eds.) Critical Security Studies. Mineápolis: University of Minnesota Press, 1997. 379p.

van KRIEKEN, P. Terrorism and the Changing Paradigm of the Migration Movements. In: HENKE, H. (Ed.) Crossing over: Comparing Recent Migration in the United States and Europe. Oxford: Rowman \& Littlefield Publishing Group, 2005, p. 47-76.

KUSHEN, R. France needs to stop Roma evictions. Euobserver.com [online], 04 de setembro, 2012. Disponível em: http://euobserver.com/opinion/117366. Acesso em: 14 de out. 2012.

LAGODNY, O. The European Convention on the Supression of Terrorism: A Substantial Step to Combat Terrorism? University of Colorado Law Review, v. 60, p. 583-600, 1989.

LAHAV, G.; MESSINA, A.; VAZQUEZ III, J. P. The Immigration-Security Nexus: A view from the European Parliament. Paper prepared for the EUSA BIENNIAL INTERNATIONAL CONFERENCE, 10., Montreal, 17-19 de Maio de 2007. Disponível em: http://www.unc.edu/euce/eusa2007/papers/lahav-g08g.pdf. Acesso em: 29 de jun. 2012.

LAITINEN, I. Frontex and the Border security of the European Union. European View, v. 5, p. 57-62, 2007.

Frontex: An Inside View. European Institute of Public Administration, Maastricht, n.3, p. 31-34, 2008. EIPASCOPE. Disponível em http://www.eipa.eu/files/repository/eipascope/20090203161640_SCOPE20083_5_IllkaLaitinen.pdf. Acesso em: 07 de jul. 2012.

LAPID, Y. The Third Debate: On the Prospects of International Theory on a PostPositivist Era. International Studies Quarterly, v. 33, p. 235-254, 1989.

LAVENEX, S. Justice and Home Affairs: Communitarization with Hesitation. In: WALlACE, H.; WALLACE, W. (Eds.) Policy-Making in the European Union. Oxford: Oxford University Press, Sixth Edition, 2010, p. 457-478.

LAWSON, S. Articulation, antagonism, and intercalation in Western military imaginaries. Security Dialogue, Oslo, v. 42, n. 1, p. 39-56, fev. 2011. 
LEANDER, A. Habitus and Field. Copenhagen Business School working paper, Copenhagem, n.9, nov. 2009. Disponível em http://openarchive.cbs.dk/bitstream/handle/10398/7966/Habitus_and_Field_Worki ng_Paper.pdf?sequence=1. Acesso em: 26 de ago. 2012.

The Promises, Problems and Potential of a Bourdieu-inspired Staging of International Relations. International Political Sociology, v. 5, n. 3, p. 294-313, set. 2011.

LEBOW, R. N. The Cuban Missile Crisis: Reading the Lessons Correctly. Political Science Quarterly, v. 98, n. 3, p. 431-458, 1983/4.

Interdisciplinary Research and the Future of Peace and Security Studies. Political Psychology, v. 9, n. 3, p. 507-525, set. 1988.

LÉONARD, S. Frontex and the Securitization of Migrants through Practices. MIGRATION WORKING GROUP SEMINAR, 1., Florença: European University Institute, 9 de fevereiro de 2011. Disponível em http://www.nuovicittadini.it/briguglio/immigrazione-e-asilo/2011/febbraio/artleonard-frontex.pdf. Acesso em: 10 de jul. 2012.

EU Border Security and Migration into the European Union: FRONTEX and Securitization through Practices. European Security, Londres, v.19, n.2, p. 231-254, 2010.

; KAUNERT, C. Reconceptualizing the audience in securitization theory. In: BALZACQ, T. (Ed.) Securitization Theory: How Security Problems Emerge and Dissolve. Nova York: Routledge, 2011, p 57-76.

LEVY, C. The European Union after 9/11: The Demise of a Liberal Democratic Asylum Regime? Government and Opposition, v. 40, n. 1, p. 26-59, 2005.

LUGNA, L. Institutional Framework of the European Union Counter-Terrorism Policy Setting. Baltic Security and Defence Review, Tartu, v. 8, p. 101-127, 2006.

LYN-JONES, S. International Security Studies After the Cold War: An Agenda for the Future. CIAO Working Papers, dez. 1991.

MACFARLANE, S. N.; KHONG, Y. F. Human Security and the UN: A Critical History. Bloomington: Indiana University Press, 2006. 341p.

MAHONY, H. EU politicians express concern over rise of far-right. Euobserver.com [online], 23 de abril, 2012. Disponível em: http://euobserver.com/843/115994. Acesso em: 18 de maio. 2012.

MARENIN, O. Challenges for Integrated Border Management in the European Union. Geneva Centre for the Democratic control of Armed Forces (DCAF), n.17, 2010. Occasional Paper. Disponível em http://syb.icisleri.gov.tr/ortak_icerik/syb/CHALLENGES\%20FOR\%20INTEGRA 
TED\%20BORDER\%20MANAGEMENT\%20IN\%20THE\%20EUROPEAN\%20

UNION.pdf. Acesso em: 09 de jul. 2012.

MARIN, C. Percées électorales de l'extrême droite au Nord et à l'Est de l'Europe. Le Monde diplomatique [online], março de 2012. Disponível em: http://www.monde-diplomatique.fr/cartes/ueextremesdroites. Acesso em: $18 \mathrm{de}$ maio. 2012.

MCDONALD, M. Securitization and the Construction of Security. European Journal of International Relations, Londres, v. 14, n.4, p. 563-587, 2008.

MCSWEENEY, B. Identity and Security: Buzan and the Copenhagen school. Review of International Studies, v. 22, n. 1, p. 81-94, 1996.

MEARSHEIMER, J. The False Promise of International Institutions. International Security, v. 19, n. 3, p. 5-49, 1994.

MELOTTI, U. International migration in Europe: social projects and political cultures. In: MODOOD, T.; WERBNER, P. (Eds.) The politics of multiculturalism in the new Europe: racism, identity and community. Nova York: Zed Books, 1997. p. 73-92.

MIGRATION POLICY INSTITUTE. Managing Irregular Migration. FURURE EUROPEAN UNION CO-OPERATION IN THE FIELD OF ASYLUM, MIGRATION AND FRONTIERS, 1., Haia, setembro de 2004. Policy Brief. Disponível em: http://www.migrationpolicy.org/events/conference_policy_briefs_083104.pdf. Acesso em: 10 de jul. 2012.

MIGREUROP. Internments: CPT and other camps. Conflitti Globali, n. 4, fevereiro, 2007. Disponível em: http://www.libertysecurity.org/module/pdfs/CHALLENGE2009_Conflitti_Globali.pdf. Acesso em: 10 de set. 2012.

Detention of foreigners: the first effects of the "return" directive. Migreurop press release [online], 14 de outubro, 2008. Disponível em: http://www.migreurop.org/article1318.html. Acesso em: 25 de jun. 2012.

MONAR, J. The Dynamics of Justice and Home Affairs: Laboratories, Driving Factors and Costs. Journal of Common Market Studies, v. 39, n.4, p. 747-764, 2001.

The Project of a European Border Guard: Origins, Models and Prospects in the Context of the EU's Integrated External Border Management. In: CAPARINI, M.; MARENIN, O. Borders in a Globalised World. Genebra: Geneva Centre for Democratic Control of Armed Forces, 2006. Capítulo 10. Não paginado. 
. The European Union's post 9/11 approach: Global terrorism as a multidimensional law enforcement challenge. Cambridge Review of International Affairs, v. 20, n. 2, p. 261-278, julho de 2010.

MORAN, D. Strategic Theory and the History of War. In: BAYLIS, J. et al. (Orgs.) Strategy in the Contemporary World. New York: Oxford University Press, 2002, p. 17-44.

MOREHOUSE, C.; BLOMFIELD, M. Irregular Migration in Europe. Transatlantic Council on Migration. Washington: Migration Policy Institute, dez. 2011. 22p.

van MUNSTER, R. The War on Terrorism: When the Exception Becomes the Rule. International Journal of Semiotics of Law, v. 17, p. 195-230, 2004.

Logics of Security: The Copenhagen School, Risk Management and the War on Terror. Dinamarca: University of Southern Denmark, n. 10, 2005. Political Science Publications. Disponível em http://static.sdu.dk/mediafiles/Files/Om_SDU/Institutter/Statskundskab/Skriftserie /05RVM10.pdf. Acesso em: 06 de jul. 2012.

MUPPIDI, H. The Politics of the Global. Minneapolis: University of Minnesota Press, 2004. 154p.

MUTIMER, D. Beyond Strategy: Critical Thinking and the New Security Studies. In: SNYDER, C. (Ed.) Contemporary Security and Strategy. Londres: Palgrave Macmillan, 1999. p.77-101.

NEAL. A. Securitization and risk at the EU Border: The Origins of FRONTEX. Journal of Common Market Studies, v. 47, n 2, p. 333-356, 2009.

Foucault in Guantánamo: Towards an Archeology of the Exception. Security Dialogue, v. 37, n. 1, p. 31-46, 2006.

NIELSEN, N. Hawkish step on EU borders outrages MEPs. Euobserver.com [online], 08 de junho, 2012a. Disponível em: http://euobserver.com/22/116545. Acesso em: 25 de jun. 2012.

. Italy trampling on asylum seekers' right, NGOs say. Euobserver.com [online], 06 de julho, 2012b. Disponível em: http://euobserver.com/justice/116899. Acesso em: 11 de out. 2012.

EU border chief: 23,000 lives saved last year. Euobserver.com [online], 11 de outubro, 2012c. Disponível em: http://euobserver.com/justice/117836. Acesso em: 11 de out. 2012.

NYE, J. The Contribution of Strategic Studies: Future Challenges. The Adelphi papers, v.29, n.235, p. 20-34, 1989. 
NYE, J; LYN-JONES, S. International Security Studies: A Report of a Conference on the State of the Field. International Security, v. 12, n. 4, primavera, p. 5-27, 1988.

NORMAN, P. Governing the Third Pillar: Institutional development and external relations in justice and home affairs before and after September $11^{\text {th }}$. In: CARR, F.; MASSEY, A. (Eds.) Public Policy and the New European Agendas. Massachusetts: Edward Elgar Publishing, 2006. p.219-232.

OCCHIPINTI, J. The politics of EU policy cooperation: Towards an European FBI? Londres: Lynne Rienner Publishers, 2003. 287p.

ONUF, N. Structure? What Structure? International Relations, v. 23, n. 2, p. 183-199, 2009.

ORTIZ, R. A Sociologia de Pierre Bourdieu. São Paulo: Olho d'Água, 2003. $169 \mathrm{p}$.

OTAN. Homegrown terrorism: how the EU sees it. [video] Disponível em http://www.nato.int/docu/review/2012/Threads-Within/Homegrown-terrorism-

EU/EN/index.htm. Acesso em: 16 de ago. 2012.

PAPADEMETRIOU, D. Coming together or pulling apart? The European Union's struggle with immigration and asylum. Washington: Carnegie Endowment for International Peace, 1996, 133p.

PARKES, R. The EU under Siege? The Development of EU Migration Policy from Treaty of Amsterdam to the European Constitution. Foreign Policy in Dialogue, v. 8, n. 22, p. 7-15, 2007.

PARLAMENTO EUROPEU; CONSELHO EUROPEU. Regulation No. 1168/2011 amending Council Regulation (EC) No. 2007/2004 establishing a European Agency for the Management of Operational Cooperation at the External Borders of the Member States of the European Union. Bruxelas, 27 de novembro de 2011. Disponível em: lex.europa.eu/LexUriServ/LexUriServ.do?uri=OJ:L:2011:304:0001:0017:EN:PD F. Acesso em: 01 de set. 2012.

PARLAMENTO EUROPEU. Report on the proposal for a Council regulation establishing a European Agency for the Management of Operational Co-operation at the External Borders. Bruxelas, 24 de fevereiro de 2004. Disponível em: http://www.europarl.europa.eu/sides/getDoc.do?pubRef=//EP//NONSGML+REP ORT+A5-2004-0093+0+DOC+PDF+V0//EN. Acessado em 12 de out. 2012.

PEDERSEN, O. The Debate of European Security in Denmark. In: LAMAITRE, P.; WÆVER, O.; TROMER, E. (Eds.) European Polyphony: Perspectives beyond East-West Confrontation. New York: St. Martin's Press, 1989. Não paginado. 
PINTO, L. Pierre Bourdieu e a Teoria do Mundo Social. Rio de Janeiro; Editora FGV, 2000, 192p.

POLLAK, J.; SLOMINSKI, P. Experimentalist but not Accountable Governance? The Role of Frontex in Managing the EU's External Borders. West European Politics, v. 32, n. 5, p. 904-924, set. 2009.

POP, V. Beefed up border control agency to respect rights. EUObserver.com [Online], 24 de fevereiro, 2010. Disponível em: http://euobserver.com/851/29544. Acesso em: 12 de mar. 2012.

. Tunisian migrant: EU treatment is 'shameful'. EUObserver.com [Online], 23 de março, 2011a. Disponível em: http://euobserver.com/22/32043. Acesso em: 13 de mar. 2012.

PRICE, D. Some remarks on elitism in information and the invisible college phenomenon in science. Journal of the American Society for Information Science, v. 22, n. 2, p. 74-75, 1971.

PROJETO CLANDESTINO. Size and Development o Irregular Migration to the EU. Policy Brief, out. 2009.

RAHOLA, F. The Space of Camps: Towards a genealogy of places of internment in the present. In: DEL LAGO, A.; PALIDDA, S. (Eds.). Conflict, Security and the Reshaping of Society: The civilization of war. Londres: Routledge, 2010. p. 185-199.

RANGEL, P. Barrados: Um ensaio sobre os brasileiros inadimitidos na Europa e o conto da aldeia global. Brasília: Abaré Editorial, 2012. 143p.

REES, W. Inside Out: The External Face of EU Internal Security Policy. In: JONES, S.; GENUGTEN, S. (Eds.) The Future of European Foreign Policy. Londres: Routledge, 2009. p. 94-108.

REID, E. Evolution of a body of knowledge; an analysis of terrorism research. Information Processing and Management, v. 33, n. 1, p. 91-106, 1997.

RETTMAN, A. Report: EU and Greece turn 'blind-eye' to racist violence. In: EUObserver.com, 11 de julho de 2012. Disponível em: http://euobserver.com/851/116933. Acesso em: 11 de jul. 2012.

RIEKMANN, S. Security, Freedom and Accountability: Europol and Frontex. In: GUILD, E.; GEYER, F. (Eds.) Security versus Justice? Police and Judicial Cooperation in the European Union. Hampshire: Ashgate Publishing, 2008. p.19-34.

RUDZIT, G. O debate teórico em segurança internacional: Mudanças frente ao terrorismo? Civitas, v. 5, n. 2, p. 297-323, jul/dez. 2005. 
SCHAIN, M. Reactions to Terrorism after September 11th: New Rules on Immigration in US and Europe: The illusion of change and convergence. Matthew B. Ridgway Center, Woking Paper, 2007. Disponível em http://www.isn.ethz.ch/isn/Digital-Library/Publications/Detail/?ots591=0c54e3b31e9c-be1e-2c24-a6a8c7060233\&lng=en\&id=46178. Acesso em 11 de jul. 2012.

SCHIFFAUER, W. Islam as civil religion: political culture and the organization of diversity in Germany. In: MODOOD, T.; WERBNER, P. (Eds.) The politics of multiculturalism in the new Europe: racism, identity and community. Nova York: Zed Books, 1997. p.147-168.

SCHMITT, C. (1922). Political Theology, Four Chapters on the Concept of Sovereignty. Chicago: University of Chicago Press, 2005, 70p.

Chicago Press, 2007.

(1932). The Concept of the Political. Chicago: University of

SECKINELGIN, H.; BIGIRUMWAMI, J.; MORRIS, J. Securitization of HIV/AIDS in Context: Gendered Vulnerability in Burundi. Security Dialogue, v.41, n.5, p. 515-535, out. 2010.

SJÖSTEDT, R. Exploring the Construction of Threats: The Securitization of HIV/AIDS in Russia. Security Dialogue, v. 39, n. 1, p. 7-29, 2008.

SMITH, S. Foreign Policy is What States Make of It: Social Construction and International Relations Theory. In: KUBÁLKOVÁ, V. (Ed.) Foreign Policy in a Constructed World. New York: M.E. Sharpe, 2001, p. 38-55.

STATEWATCH. Europol analysis files - 146,183 personal records and counting. Statewatch articles, n. 25503, abril de 2004. Disponível em: http://database.statewatch.org/article.asp?aid=25503. Acesso em: 09 de jul. 2012.

. This is hell: Romania's horrendous detention conditions.

Statewatch, n. 31405, abril de 2012. Disponível em: http://database.statewatch.org/article.asp?aid=31405. Acesso em: 09 de jul. 2012.

STEINBERG, P. Agency, Co-regulation and Comitoloy - and what about politics? A critical appraisal of the Commission's White Paper on Governance. Jean Monnet Working Paper, n. 6, 2001.

STRITZEL, H. Towards a Theory of Securitization: Copenhague and Beyond. European Journal of International Relations, v. 13, n. 3, p. 357-384, 2007.

SUHRKE, A. Human security and the protection of refugees. In: NEWMAN, E; VAN SELM, J. (Eds.) Refugees and Forced Displacement: International Security, Human Vulnerability, and the State. Tokyo: UNU Press, 2003.

SYLVESTER, C. Feminist Theory and International Relations in a Postmodern Era. Cambridge: Cambridge University Press, 1994, p.265. 
TANNO, G.; HERZ, M. A Escola de Copenhague: uma contribuição aos estudos de segurança internacional. 2002. 161p. Dissertação (Mestrado em Relações Internacionais) - Instituto de Relações Internacionais, Pontifícia Universidade Católica do Rio de Janeiro, Rio de Janeiro, 2002.

TAURECK, R. Securitisation Theory - The Story so far: Theoretical inheritance and what it means to be a post-structuralist realist. CENTRAL AND EAST EUROPEAN INTERNATIONAL STUDIES ASSOCIATION, 4., Tartu: Universidade de Tartu, 25-27 de junho de 2006. Disponível em http:// ceeisaconf.ut.ee\%2Forb.aw\%2Fclass\%3Dfile\%2Faction\%3Dpreview\%2Fid\%3D 164452\%2FTAURECK.doc\&ei=6WU. Acesso em: 26 de ago. 2012.

THIRY-CHERQUES, H. Pierre Bourdieu: a teoria na prática. Revista de Administração Pública, v. 40, n. 1, p. 27-55, 2006.

TICKNER, J. A. Gender in International Relations: Feminist Perspectives in Achieving Global Security. New York: Columbia University Press, 1992, 180p.

Feminists Responses to International Security Studies. Peace Review, v. 16, n. 1, p. 43-48, 2004.

TILLY, C. War Making and State Making as Organized Crime. In: EVANS, P. et al. Bringing the State Back In. Cambridge: Cambridge University Press, 1985, p. $169-187$.

TRAYNOR, I. EU border police 'turning blind eye' to abuse of migrants in Greece. The Guardian [Online], 21 de setembro, 2011. Disponível em: http://www.guardian.co.uk/world/2011/sep/21/eu-border-police-bline-eyemigrant-abuse. Acesso em: 20 de jun. 2012.

TSOUKALA, A. Democracy against security: The Debates about Counterterrorism in the European Parliament, September 2001-June 2003. Alternatives: global, local, political, v. 29, n. 4, p. 417-440, 2004.

Security, Risk and Human Rights: A vanishing relationship? CEPS Special Report, setembro, 2008. Disponível em: http://aei.pitt.edu/11744/1/1703.pdf. Acesso em: 13 de jul. 2012.

ULLMAN, R. Redefining Security. International Security, v. 8, n. 1, p. 129-153, 1983.

VALLE, I. A obra do sociólogo Pierre Bourdieu: uma irradiação incontestável. Educação e Pesquisa, v. 33, n. 1, p. 117-134, 2007.

VAN SELM, J. Immigration and Asylum or Foreign Policy: The EU's Approach to Migrants and Their Countries of Origin. In: LAVENEX, S.; UÇARER, E. (Eds.) Migration and the externalities of European Integration. Oxford: Lexington Books, 2003. p.143-160. 
VAUGHAN-WILLIAMS, N. The Shooting of Jean Charles de Menzes: New Border Politics? Alternatives, v. 32, p. 177-195, 2007.

Borderwork beyond Inside/Outside? Frontex, the Citizendetective and the War on Terror. Space and Polity, v. 12, n. 1, p. 63-79, abr. 2008 .

The generealised bio-political border? Re-conceptualising the limits of sovereign power. Review of International Studies, v. 35, p. 729-749, 2009.

VAUGHN, J. The Unlikely Securitizer: Humanitarian Organizations and the Securitization of Indistincveness. Security Dialogue, n. 40, p. 263-285, 2009.

VENTURINI, T. Building on faults: how to represent controversies with digital methods. Public Understanding of Science, v. 20, n. 10, p. 1-17, 2010.

; LATOUR, B. The Social Fabric: Digital Traces and Qualiquantitative Methods. In: Proceedings of Future en Seine 2009. Paris: Cap Digital, $2010 . \quad$ Disponível em http://www.tommasoventurini.it/web/uploads/tommaso_venturini/TheSocialFabri c.pdf. Acesso em: 10 de jul. 2012.

DE VRIES, G. Discurso no Seminário de Cooperação da União Europeia na Preparação para Ataques com Agentes CBRN, 2004. Disponível em: http://www.consilium.europa.eu/uedocs/cmsUpload/Hague7July2004.pdf.

Acesso em: 14 de out. 2012.

WAHL, T. The European Union as an Actor in the Fight Against Terrorism. In: WADE, M.; MALJEVIĆ, A. (Eds.) A War on Terror? The European Stance on a New Threat, Changing Laws and Human Rights Implications. Nova York: Springer, 2010, p. 107-170.

WALKER, R. B. J. Inside/Outside: International Relations as Political Theory. Cambridge: Cambridge University Press, 1993, 233p.

WALLACE, H. et al. EU Policy-Making in Challenging Times: Adversity, Adaptability, and Resilience. In: WALLACE, H. et al. (Eds.) Policy-Making in the European Union. New York: Oxford University Press, Sexta Edição, 2010, p. 481-501.

WALT, S. The Renaissance of Security Studies. International Studies Quarterly, v. 35, n. 2, p. 211-239, jun. 1991.

WALTZ, K. (1959). Man, the State and War: A Theoretical Analysis. New York: Columbia University Press, 2001. 
WARDE, A. Practice and Field: revising Bourdieusian concepts. CRIC Discussion paper, n. 65, abril, 2004. Disponível em: http://www.cric.ac.uk/cric/pdfs/dp65.pdf. Acesso em: 14 de ago. 2012.

WATSON, R.; SHACKLETON, M. Organized Interests and Lobbying in the EU. In: BOMBERG, E; STUBB, A. (Eds.) The European Union: How Does it Work? Oxford: Oxford University Press, 2003, p. 88-110.

WENDT, A. Anarchy is what States make of it: The social construction of Power Politics. International Organization, Cambridge, v. 46, n. 2, p. 391-425, 1992.

Social Theory of International Politics. Cambridge: Cambridge University Press, 1999, 429p.

WILLIAMS, M. Words, Images, Enemies: Securitization and International Politics. International Studies Quarterly, v. 47, pp. 511-531, 2003.

WILLIAMS, P (Ed.). Security Studies: An Introduction. Londres: Routledge, 2008, 568p.

WILKINSON, C. The Copenhagen School on tour in Kyrgyzstan: Is securitization Theory Useable Outside Europe?. Security Dialogue, v. 38, n. 1, p. 5-25, 2007.

WILSON, W. Fourteen points. Mensagem para o Congresso, 8 de janeiro de 1918. Arquivos do Senado dos Estados Unidos; Grupo de Arquivo 46. Disponível em http://www.ourdocuments.gov/doc.php?doc=62\&page=transcript. Acesso em 05 de jul. 2012.

WOLFF, S.; SCHOUT, A. FRONTEX: More of the same? EUSIM - THE GOVERNANCE OF ASYLUM AND MIGRATION IN THE EUROPEAN UNION, 1., Universidade de Salford: Centre for European Security, 26 - 27 de Janeiro de 2012. Disponível em http://www.clingendael.nl/publications/2012/20120126_frontex_final_schout_wol ff.pdf. Acesso em: 11 de jul. 2012.

WÆVER, O. Security, the Speech Act: Analysing the politics of a word. In: RESEARCH TRAINING SEMINAR SOSTRUP MANOR, 1989, Jerusalém/Tel Aviv, 25-26 de junho.

Securitization and Desecuritization. In: LIPSCHUTZ, R (Ed.) On Security. Nova York: Columbia University Press, 1995, p. 26-86.

The Sociology of a not so International Discipline: American and European Developments in International Relations. International Organizations, v. 52, n. 4, p. 687-727, 1998.

Insecurity, Security, and Asecurity in the West European non-war Community. In: ADLER, E.; BARNETT, M. Security Communities. Cambridge, Cambridge University Press, 2000, p. 69-118. 
Aberystwyth, Paris, Copenhagen: New 'Schools' in Security Theory and their Origins between Core and Periphery. In: INTERNATIONAL STUDIES ASSOCIATION CONFERENCE, 2004, Montreal, 17-20 de março.

480, 2008.

Politics, security, theory. Security Dialogue, v. 42, n. 4-5, p. 465-

. Fear and forgetting: How to leave longstanding conflicts through desecuritization. CENTER FOR ADVANCED SECURITY THEORY RESEARCH SEMINAR, 1., Copenhagen: Copenhagen University, 29 de outubro de 2008. Disponível

http://cast.ku.dk/events/seminars/securitization_theory_as_a_tool_for_conflict_res olution/. Acesso em: 11 de jul. 2012.

ZIMMERMANN, D. The European Union and Post-9/11 Counterterrorism: A Reappraisal. Studies in Conflict \&Terrorism, v. 29, p. 123-145, 2006.

ZUCCONI, M. Migration and Security as an Issue in US-European Relations. In: TIRMAN, J. (Ed.) The Maze of Fear: Security and Migration After 9/11. New York: New Press, 2004. 322p. 